\title{
Rudolf Neuhäuser
}

\section{The Romantic Age \\ in Russian Literature - \\ Poetic and Esthetic Norms}

\section{An Anthology of Original Texts \\ $(1800-1850)$}

Verlag Otto Sagner München · Berlin · Washington D.C.

Digitalisiert im Rahmen der Kooperation mit dem DFG-Projekt „Digi20“

der Bayerischen Staatsbibliothek, München. OCR-Bearbeitung und Erstellung des eBooks durch den Verlag Otto Sagner:

http://verlag.kubon-sagner.de

() bei Verlag Otto Sagner. Eine Verwertung oder Weitergabe der Texte und Abbildungen, insbesondere durch Vervielfältigung, ist ohne vorherige schriftliche Genehmigung des Verlages unzulässig. 


\section{Slavistische BeIträge}

BEGRÜNDET VON ALOIS SCHMAUS

HERAUSGEGEBEN VON JOHANNES HOLTHUSEN UND JOSEF SCHRENK

REDAKTION: PETER REHDER

Band 92 


\author{
RUDOLF NEUHÄUSER
}

THE ROMANTIC AGE IN RUSSIAN LITERATURE: POETIC AND ESTHETIC NORMS

An Anthology of Original Texts (1800-1850)

VERLAG OTTO SAGNER · MÜNCHEN

1975 
This book has been published with the help of a grant from the Humanities Research Council of Canada, using funds provided by the Canada Council

\section{Baverlsctio Staatsblbllothek München}

$$
\text { ISBN 3-87690-104-9 }
$$

Copyright by Verlag Otto Sagner, München 1975

Abteilung der Firma Kubon \& Sagner, München

Druck: Alexander Großmann

8 München 19, Ysenburgstraße 71 


\section{CONTENTS}

Preface

\section{PART ONE}

Problems of the Literary Evolution

1. Periodization 2

2. The Evolution of a National Literary Language 22

3. The Evolution of a National Literature 38

\section{PART TWO}

Interpretations I - Literary Trends

4. Sentimental Literature $\quad 62$

- Sentimental Esthetics 64

- Criticism of Sentimental Literature 68

$\begin{array}{ll}\text { 5. Preromantic Literature: } & 72\end{array}$

- Preromantic Esthetics 75

- Criticism of Preromantic Literature $\quad 79$

6. Romanticism: $\quad 82$

- Terminology: 'romanicheskii' and 'romanticheskii' 87

- Chronological Limits $\quad 90$

- Definitions of Romanticism 94

- The Feud between Neoclassicism and Romanticism 101

- Criticism of Romantic Literature 111

\section{PART THREE}

Interpretations II - Poetics

7. Definitions of Literature 122

8. The Writer and Genius 144

9. Beauty, Inspiration, and Imagination 165 
PART FOUR

Interpretations III - Style and Genres $\quad 174$

10. Three Romantic Styles 178

11. Genres 190

- Poetry 200

- Drama 229

- Prose 246

Select Bibliography

Index 


\section{PREFACE}

The works of romantic writers in Russia are fairly easily accessible. Critical discussions of romantic esthetics, literary polemics, parodies, reviews of romantic literature, all of which appeared in great numbers in the periodical press of the time, are more difficult to locate. Many journals, especially of the first two decades of the 19th century, have not been reprinted. Others of a later date are now available in microprint editions, yet their study presents the student with many problems. Above all, there exists no systematic presentation of critical texts so far. The Anthology is intended to provide such a systematic and analytical compendium of original texts, so as to afford some insight in the poetic, stylistic, and conceptual norms which determined the nature and evolution of literature during the first half of the 19 th century.

The texts have been selected and grouped according to topics. The date of publication (or writing, where there is a significant span of time between writing and publication) has been indicated on the margin. Wherever possible, texts have been based on the first publication. PART ONE is devoted to the self-definition of Russian literature in terms of its history, language and style, and its national individuality. PART TWO provides discussions and interpretations of the two trends which ushered in the Romantic Age, sentimental and preromantic literature, romantic literature, and the neoclassicist trend, which opposed the romantic movement from its inception into the 1830's. PART THREE illustrates various concepts of romantic esthetics which have been considered of central significance for the European romantic movement, (1) the romantic concept of literature with its implicit emphasis on symbol, myth, and a new, organic view of nature; (2) the genius; and (3) the role of the ideal, imagination, and inspiration. PART FOUR illustrates the evolution of the romantic understanding of literary genres and cultural types, reflected in national styles. An Index facilitates cross references and allows to locate all texts by one author as well as all references to him. Many texts are followed by extensive notes which provide further explanation. Although the Romantic Age proper was confined to the 1820's and 1830's, the chronological frame of the Anthology has been extended to include half a century of Russian literature from sentimentalism to early realism. This will permit the reader to see the romantic movement in a wider perspective. Some aspects of romantic literature were anticipated by sentimental authors from the 1780's and 1790's onwards. Many romantic features remained part of literature when writers no 
longer considered themselves romantic.

Romanticism was a literary movement of an international character. It first rose to prominence in Germany where it was supported by idealistic philosophy and a well established tradition of esthetic thought. German, but also English and French influences were significant for the Russian literary scene from the beginning of the period to its end. Brief introductions to the various sections of the Anthology. attempt to delineate this back. ground, which is also reflected in the annotation.

The author hopes that the advanced undergraduate as well as the graduate student, the teacher and scholar in Russian and comparative literature will find this systematic arrangement of original texts of use in their work. It is a pleasant task to thank the University of Western Ontario for generous support, Canada Council for a research grant enabling me to work in Soviet libraries, and the Humanities Research Council of Canada for a generous publication grant.

London, October 1973

Rudolf Neuhäuser 


\section{PART ONE}

Problems of the Literary Evolution 


\section{PERIODIZATION}

\section{Introduction}

To Russian romantic writers the literary tradition fell into easily recognizable periods, each of which was dominated by one or two outstanding authors. The beginning of modern Russian literature was seen either in the poetry of Feofan Prokopovich and Kantemir, two writers of the age of Peter the Great, or the works of Lomonosov and Sumarokov. The age of Catherine the Great was generally considered the climax of 18 th-century Russian literature. Derzhavin appeared as the major author whose poetry foreshadowed the lyricism and clarity of the verse of a later age. The first two decades of the new century were dominated by Karamzin, Zhukovskii, and Batiushkov. This period was characterized by continued polemics between the adherents of Karamzinian sentimentalism and neoclassicists whose spokesman was Admiral Shishkov. The Karamzinian trend was continued in the early romanticism of Zhukovskii's poetry, while the neoclassicist position received support from a group of young writers (called mladoarkhaisty by lu. Tynianov) whose main representatives were Katenin, Griboedov, and Kiukhel'beker.

According to contemporary critics, the romantic age began either with the poetry of Zhukovskii and Batiushkov (i.e., towards the end of the first decade of the 19th century), or alternatively with Ozerov's drama on Ossianic themes, Fingal (1805, Viazemskii), or Pushkin's early work (especially his poem Ruslan i Liudmila, 1820). The 1820's were dominated by Pushkin. While his era saw the almost exclusive rule of poetry over all other genres, the ensuing period reversed this development. The rise of the historical novel and the povest' (novella) introduced a new emphasis on prose, which found a first climax in the historical novels of Zagoskin, the ultra-romantic novellas of Bestuzhev-Marlinskii, the novels of Vel'tman, and the tales of Gogol'. Simultaneously romanticism began to decline and such new literary trends as the Physiological Sketch (late 1830's) and the Natural School pointed to the imminent rise of realism.

It was during this last period that other vital changes took place: writing became a profession; literature was commercialized; writers received a regular remuneration for their work; journalism became increasingly important. Literature ceased to be the almost exclusive domain of welleducated aristocrats. The Modern Age had begun. 
1802 Н. М. Карамзнн, „Пантеон русскнх авторов” Вестник Eвропы, 20 (1802).

Но истинный век авторский начался в Россия со времен Петра Великого: ибо искусство писать есть действие просвещения. Феофан и Кантемир составляют сию первую эпоху; за нею следует эпоха Ломоносова и Сумарокова; третьею должно назвать время Екатерины Великой, уже богатое числом авторов; а четвертой . . . мы еше ожкдаем . . .

Karamzin published short biographies of famous men of Russian literature such as the mythical Boian, Nestor, Nikon, Simeon Polotskii, Feofan Prokopovich, Kantemir, Trediakovskii and many others in his Panteon which appeared originally in 1801-1802 and went through three editions. Karamzin's division of periods reflects the early nineteenthcentury view of Russia's literary evolution.

1815 Н. И. Греч, „Обозренне русской литературы в 1814 году” Сочинения, III (Санкт-Петербург, 1855).

В царствование Елисаветы вдруг возникла Русская Словесность, охивленная лучем отечественного солнща. Явился Ломоносов, восхитил слух и сердиа соотечественников громкою поззиею.

. . . История этого периода [Катерины Великой] имеет две эпохи. Первая есть продолжение эпохн прежнего царствования, но в большем виде, с лучшими и быстрейшими успехами. В эту эпоху появились Петров, Херасков, Державин, Хемницер, Фонвизин, Богданович, Капнист, Княжнин, Костров, Майков. Стихотворения того времени будут жить с русским языком. Вторая эпоха есть плод учреждения в царствование Елизаветы Московского Университета, и начннается в исходе предпоследнего десятилетия XVII века. В это время образовались русская проза и механисм легких стихотворений. Карамзин, Дмитриев, Нелединский-Мелецкий, Муравьев показали в прозе и стихах, что русский язык способен не только к громкой поззии и к ораторским речам, но и к сочинениям в слоге простом, разговорном и нежном.

... Вообще, в течение первых пяти лет XIX века, вышло более сочинений, нежели прежде того в течение десяти лет . . .

. . . С 1808 по 1812 год господствовало в нашей литературе какоето недоумение.

... Наконец, в половине 1812 года, грянул скрывавшийся в них гром - и литература наша сначала остановилась совершенно, а потом обратилась к одной цели, споспешествованию отечественной войне. В продолжение второй половины 1812 и первой 1813 годов не только не вышло в свет, но и не написано ни одной страницы, которая не имела бы предметом тогдашних происшествий. 
... Наконец, в 1814 году, увенчавшем все напряжения и труды истекших лет, Русская Литература, посвящая поззию и красноречие в честь и славу великого Монарха своего, обратилась снова на путь мирный. уравненный, огражденный навсегда.

Elisabeth, daughter of Peter the Great, ruled Russia from 1741 to 1762 . Prominent events of her reign include the foundation of Moscow University in 1755 and the literary activity of Lomonosov.

N. I. Grech (1787-1867) edited the journal Syn otechestva (1812-1852) which was a major literary periodical before the Decembrist uprising (1825) and printed many of the foremost young writers. Grech's review was originally published there. It was here also that early polemics concerning the romantic movement appeared. Note particularly the polemics concerning Pushkin's poem Ruslan and Liudmila in 1820.

Grech's review points out the effect of the Napoleonic wars on literature which was noticeable by and large from the time of the Finnish campaign (1808) to the Congress of Vienna (1814-1815).

К. Н. Батюшков, „Чужоемое сокровкще”

Сочинения, III (Санкт-Петербург, 1886).

Словесность надлежит разделить на эпохи: I) Ломоносова; II ) Фонвизина; III ) Державина; IV) Карамзина; V) до времен наших. Сии эпохи должны быть ясными точками. Потом, не должно из виду упускать действие иностранных языков на наш язык. Переводы ученых с греческого и латинского. Что заняли мы у французов, и какое действие имели переводы романов Вольтера и проч.

Новикова труды. Влияние новорожденной немецкой словесности и отчасти английской. В чем мы успели?

In these notes which were not intended for publication, Batiushkov (1787-1855) outlined his views on the plan of a history of Russian literature. Note the increased number of periods. especially the establishment of two periods named after Lomonosov and Sumarokov respectively which preceded the age of Catherine the Great (identified here with Derzhavin). It is noteworthy that Batiushkov differentiated between Karamzin's age (1790's and early 1800 's) and his own time (early romanticism).

Н. И. Греч, Опыт краткой истории русской литературы (Санкт-Петербург, 1822).

Начало сего отделения Русской Литературы [ на две эпохи] ознаменовано преобразованием, или лучше сказать, сотворением русского языка: сим обязаны мы гению Ломоносова. Он первый умел отличить язык народный русский, но возвышенный и благородный, от языка богослужебного. не отвергая между тем красот сего последнего; он первый писал чистою русскою прозою, ввел употребление размера, свойственного лирической 
поэзии, и составил правила Русской Грамматики. . . .

Приступая к изображению перемен, происшедших в языке русском В XIX веке, должны мы начать с конца XVIII. В последние годы царствования Екатерины, как мы ужё говорили выше, началось образование русской прозы и легкой поззин. В семидесятых годах пел Богданович, писал неподражаемые Басни свои Хемницер; Фонвизин заставлял лица своих Комедий говорить по-русски; но это было только началом, слабым и неверным. В предпоследнем десятилетин XVIII века, в Москве посреди народа, который говорит самым чистым и правильным языком, начала образоваться русская дидактическая и легкая проза. В то время, когда все чувствовали недостаточность господствовавшего дотоле языка, кorда многие старались образовать оный и удалить равно от наречия черни, как и от книжной высокопарности ораторских речей, появился Карамзин. В Московском Журнале русская публика нашла то, чего давно требовало ее чувство: легкий и правильный, приятный язык, слова благородные, обороты понятные, словосочннение русское, естественное. Все читали прозу сню с удовольствием: молодые писатели с восторгом, одни приверженцы к старине с досадою. Карамзин по справедливости предлочел словосочинение французское и английское периодам латинским и немецким, в которые дотоле ковали русский язык. . . .

N. I. Grech wrote the first serious history of Russian literature. He was attacked by P. A. Katenin (1792-1853) who disagreed with Grech concerning the classification of certain authors and complained that Grech had not included the following writers in his history: Griboedov (1795-1829) whose famous comedy Gore ot uma had not appeared yet; Zhandr (1789-1873), a friend and collaborator of Griboedov; Zagoskin (1789-1852), at that time known as the author of two successful comedies; and the poet Baratynskii. He also complained that Grech had classified him as a translator rather than as an original writer. See Syn otechesti'a, 76 (1822).

Karamzin's journal appeared in Moscow in 1791 and 1792. Apart from translations from Sterne, Macpherson (Ossian), and other preromantic Western authors, Karamzin published there his Letters of a Russian Traveller, Poor Lizo, and I. 1. Dmitriev's sentimental poetry.

--, „Современная библиографня. Кннги на 1830 год." Московский телеграф. $1(1830)$.

Русские критики составляли в основание триумвират: Жуковский. Батюшков, князь $П$. А. Вяземский. О сих писателях никто и ничего, кроме похвал, говорить не смел. После них следовал другой триумвират, юная надежда наша: $A$. C. Пушкин, E. А. Баратынский, Барон Дельвиг. ... .

А. С. Пушкин шагнул выше и далее и товаришей и старого триумвирата.... 
Явились многие вновь: Н. М. Языков, С. А. Шевырев, А. Псгорельский, М. П. Погодин, Г-да Тютчев, Деларю, Хомяков, и другие. . . .

Vasilii Zhukovskij's (1783-1 852) early critical essays "Pisatel" i obshchestvo" (1808), "O basne i basniakh Krylova" (1809), "O poezii drevnikh i novykh" (1811) appeared in Vestnik Evropy which was edited by Zhukovskii between 1808 and 1810.

Konstantin Batiushkov's critical articles "Progulka v Akademiiu Khudozhestv" (1814), "Nechto o poete i poezii" (1815), "Rech' o vliianii legkoi poczii na iazyk" (1816), "O kharaktere Lomonosova" (1816), "Puteshestvie v zamok Sirei" (1816), and "Vecher u Kantemira" appeared in various journals and also in his collected works. Opyty v stikhakh iv proze (St. Petersburg, 1817).

Petr Viazemskii (1792-1878) was known mainly for his critical introductions to literary works, such as "O zhizni $i$ sochineniiakh V. A. Ozerova" (1817), "O Kavkazskom plennike" (1822), "Vmesto predisloviia k Bakhchisaraiskomu fontanu" (1824), "O Derzhavine" (1816), "Zhukovskii i Pushkin. $-O$ novoi piitike basen" (1825), and "Pis'ma iz Parizha" (1826-27). Also noteworthy are his essays "Predislovie $k$ sochineniiam I. I. Dmitrieva" (1823) and "Zamechaniia na kratkoe obozrenie russkoi literatury 1822 goda" (1823). Many of his critical articles appeared in Polevoi's journal Moskov. skii telegraf with which Viazemskii collaborated in 1825-1827.

Aleksandr Pushkin published few critical articles in the 1820's. An carly essay, "Moi zamechaniia ob russkom teatre," appeared in 1820. Other critical essays were "O predislovii gospodina Lemont'e $k$ perevodu basen I. A. Krylova" (1825), "O narodnosti $\checkmark$ literature" (1825, incomplete), "O poezii klassicheskoi i romanticheskoi" (1825, incomplete). However, most of his critical statements before 1830 were contained in his notes and letters.

Evgenii Baratynskii (1800-1844) published few critical articles. They were "O zabluzhdeniiakh $\boldsymbol{i}$ istine" (1821), "Predislovie $k$ otdel'nomu izdaniu poemy 'lidda" (1826), a critical review of A. Murav'ev's poem "Tavrida" (1827). "Predislovie k otdel'. nomu izdaniuu poemy 'Nalozhnitsa' "(1831), and an answer to N. I. Nadezhdin's critique of the poem under the title "Antikritika" (1832).

Baron Anton Del'vig (1798-1831), a close friend of Pushkin, poet and editor of the Literatumaia gazeta (1830-1831) and the almanac Severnve tsvety (1825-1832). published his critical reviews in these periodicals.

Stepan Shevyrev (1806-1864), a member of the liubomudry circle in Moscow, began to publish critical essays in the second half of the 1820 's. In 1825 he translated Tieck's and Wackenroder's Herzensergiessungen eines kunstliebenden Klosterbruders (1797) as $O b$ iskusstve $i$ khudozhnikakh. The journal Moskovskii vestnik. founded in 1827 by Moscow adherents of Schelling (formerly the liubomudry circle), provided a forum for his critical views. Two early articles were "Razgovor o vozmozhnostiakh naiti edinyi zakon dlia iziashchnogo" (1827) and "Zamechaniia na zamechanie kniazia Via. zemskogo o nachale russkoi poezii" (1827). Shevyrev's review of the second part of Goethe's Faust received the compliments of the author. Shevyrev's lectures on the history and theory of literature (1834-1835) were published in 1836. The major portion of his critical works appeared in the 1830's and 1840's.

Mikhail Pogodin (1800-1875), historian, critic, and journalist, edited the Moskorskii vestnik (1827-1830). In 1826 he edited the almanac Dennitse in which Tiutchev was published. Like Shevyrev he became a slvophile in the late 1830 's. His historical tragedy Marfo Posednitsa (1830) earned him fame. and tales.

Antonii Pogorel'skii (Aleksei Perovskii, 1787-1836), author of romantic novellas

Mikhail Delariu (1811-1868), poet of the Pushkin Pleiad.

Nikolai lazykov (1803-1846), poet, author of light, often frivolous poetry. In the 1840 's he accepted slavophile views and became increasingly conservative.

Aleksei Khomiakov (1804-1860), poet, philosopher and theologian, was married to the sister of the poet lazykov. He became one of the leading ideologists of the slavophiles. In the late 1820's he was a collaborator on the journal Moskor'skii vestnik.

Fedor Tiutchev (1803-1873), diplomat and philosophically inclined poet, was close to slavophile ideas in his political views. 
Литературу нашу девятьнадиатого столетия можно разделить на три эпохи, различные особенностью направления каждой из них, но связанные единством их развития. Характер первой эпохи определяется влиянием Карамзина; средоточием второй была Муза Жуковского; Пушкин может быть представителем третьей. . . .

Кажется, кто-то разбудил полусонную Россию. Из ленивого равнодушия она вдруг переходит $к$ жажде образования, ищет учения, книг, стыдится своего прежнего невежества и спешит породниться с иноземными мнениями. Когда явился Карамзин, уже читатели для него были готовы; а его удивительные успехи доказывают не столько силу его дарований, сколько повсюду распространившуюся любовь $K$ просвещению. . . .

Новиков не распространил, а создал у нас любовь к наукам и охоту к чтению. Прежде него, по свидетельству Карамзина, были в Москве две книжные лавки, продававшие ежегодно на 10 тысяч рублей; через несколько лет их было уже 20, и книг продавалось на 200 тысяч. Кроме того Новиков завел книжные лавки и в других и в самых отдаленных городах России; распускал почти даром те сочинения, которые почитал особенно важными; заставлял переводить книги полезные, повсюду распространял участников своей деятельности, и скоро не только вся Европейская Россия, но и Сибирь начала читать. Тогда отечество наше было, хотя не надолго, свидетелем события, почти единственного в летописях нашего просвешения: рождения общего мнения. . .

Может быть, сам Карамзин обязан своей первой образованностью Новикову и его друзьям-единомышленникам. По крайней мере в их кругу началось первое развитие его блестящих дарований. ...

Идеяльность, чистота и глубокость чувств; святость прошедшего; вера в прекрасное, в неизменяемость дружбы, в вечность любви, в достоинство человека и благость Провидения; стремление к неземному; равнодушие ко всему обыкновенному, ко всему, что не душа. что не любовь. одним словом, вся поэзия жизни, все сердие души, если можно так сказать. явилось нам в одном существе, и облеклось в пленительный образ Музы Жуковского. В ее задумчивых чертах прочли мы ответ на неясное стремление к лучшему и сказали: „Вот чего недоставало нам!”. . .

Любовь к литературе германской, которой мы обязаны Жуков скому, все более и более распространяясь в нашей словесности, бьла весьма заметна и в произведения прошедшего года. Между поэтами немецкой школы отличаются имена Шевырева, Хомякова и Тютчева. 
The almanac Dennitsa was published in Moscow from 1830 to 1834. Collaborators were Baratynskii, Venevitinov, Viazemskii, Glinka, Del'vig, Polevoi, Pushkin. Tiutchev, et al. I. V. Kireevskii wrote the annual reviews of Russian literature. His survey for 1830 received high praise from Pushkin (cf. Literatumaia gazeta. No. 8, 1830).

1832 Н. И. Надеждни (?), „Летотисн отечественнои словесности. Последняя глава Евгения Онегиня ... Стихотворения А. Пуиккина, 3-я фасть..." Телескоп, $\mathbf{X X ( 1 8 3 2 ) .}$

... Несколько последних лет в исторни нашей словесности по всем правилам можно назвать эпохою Пушкина . . . Но теперь - какая уднвительная перемена! Произведения Пушкина являются и проходят почти неприметно. . . . Между журнальными насекомыми, Северная пчела, ползавшаяся некогда перед любнмым поэтом, чтобы поживиться от него хотя росинкой сладкого меду, теперь осмеливается жужокать ему в приветствие, что в последних стихотворениях свонх - Пушкин отжил!!!. . .

Cия третья часть содержит в себе пронзведения трех последних лет, с 1829 по 1831 год: и, признаемся, син три года показались нам печальной лестницей ощутительного упадення поэта.

Sevemaia pchela (1825-1864), a conservative joumal, was edited by F. V. Bulgarin (1789-1859) and N. I. Grech (1787-1867). The "decline" of Pushkin's fame in the 1830 's was not entirely due to negative reviews in this journal. S. P. Shevyrev demanded a prosodicheskaio reformo in favor of a less effeminate poetic style (cf. his article "O vozmozhnosti vvesti ital'ianskuju oktavu $v$ russkoe stikhoslozhenie" in Teleskop, Pt. III [1831], pp. 263-299 and pp. 466-491). Belinskii echoed his demand later (1835), when he said: "Vas pleniaiut stikhi Pushkina! Stydites"! Oni gladkj, zvuchny; a eto khudo-oni iznezhili, rasslabili nervy vashego slukha!" (Polnoe sobranie sochinenii. I [M. 1955], p. 328).

1833 А. А. Бестулев-Марлипски, „О романе Н. Полевого, „Клатва прн rpoбe Господесм' "

Московский телегреф, 15-18 (1833).

Тредьяковский отпугнул русских надолго от гекзаметров и древних свонми попыткамн. Ломоносова, правда, хвалили все . . . и никто не читал! . . Публнка зкспликовала свою бесинерчию, что ей нечего читать. Аттенчия, с которой она приняла Курганова письмовник, ободрила писак на дальнейшие подвиги, и вот Скюдери обновилась для нас в Феодоре Эмине, Реньяр назвался Княжниным, трагедия завыла Сумароковым, эпопея отпела себя в Хераскове. И вдруг из этого моря миндального молока возник огнедышаший Державин и взбросил до 
звезд медь и пламя русского слова. Самородный великан этот пошел в бой поэзии по безднам, надвинул огнепернатый шлем, охватив на бедро луч солнца, раздавливая хребты гор пятою, кидая башни за облака. . . . Все читали Державина - очень немногие понимали. Публике нужна была словесность для домашнего обихода.... И вот Богданович промолвился очень мило своею „Душенькою”. И вот Фонвизин запечатлел для потомства лица своих современников-провинциалов. И вот явился Дмитриев с легким стихом, с летучим рассказом, с наречием лучшего общества, кой-где с прозе ленью народности. Но почти весь он состоял из переводов. Наконец блеснул образователь нашей прозы Карамзин. Судьба дала ему две почти несовместные для других выгоды: внушить в русских романтическую мечтательность и потом заставить их полюбить родную историю; . . .

. . . Русская словесность еще пережевывала Мармонтеля и мадам Жанлис. Один только самобытный, неподражаемый Крылов обновлял повременно и ум и язык русский во всей их народности. Только у него были они свежи собственным румянцем, удалы собственными силами. Он первый показал нам их без пыли древности, без французской фольги, без немецкого венка незабудок. Мужички его - природные русские мужички; . . .

Но он пересадил только один цветок его, один из необъятной его природы. Еще Русь отзывалась грустными напевами Жуковского, еще перед очами нашими носились туманные образы его поззии, еще сердце теплилось его неземною любовью, его отрадными надеждами замогильными, когда блеснул Александр Пушкин, резвый, дерзкий Пушкин, почти ровесник своему веку и вполне родной своему народу. Овладев языком, овладеваем страстями до глубины души, он скоро мог сказать вниманию публики: „Мое!”

.. . Карамзин заохотил нас к преданиям нашей страны; археологические попытки собрали кой-какие элементы для романа.

A. A. Bestuzhev-Marlinskii (1797-1837) was one of the foremost literary critics of the 1820 's and the author of novellas and poems. His reviews of Russian literature in Poliarnaia zvezde $(1823,1824,1825)$ brought him early fame. He participated in the Decembrist uprising and later served in the Caucasus. His ultra-romantic tales of the 1830's made him famous throughout Russia.

Madeleine de Scudery (1707-1701). Author of pseudohistorical novels.

Jean Francois Marmontel (1723-1799). His Elements de Littérature, originally written as a contribution to Diderot's Encyclopedie, was widely known in Russia, as was also his other work, Poétique francaise.

Mme Genlis (1746-1830). Author of numerous sentimental society novels, popular in Russia in the early 1800 's.

Jean-Francois Regnard (1655-1709). Author of comedies, translated into Russian in the 1760's and 1770's. 
1834 В. Г. Белинский, „Литературные мечтания" Молва, 38-52 (1834).

Ломоносов - это Петр нашей литературы: вот, кажется мне, самый верный взгляд на него. . . .

Литература наша. без всякого сомнения, началась в 1739 году, когда Ломоносов прислал из-за гранишы свою первую оду „На взятие Хотина". Нужно ли повторять, что не с Кантемира и не с Тредьяковского, а тем более не с Симеона Полошкого, началась наша литература? Нужно ли доказывать, что „Слово о полку Игоревом”, „Сказание о донском побоище”, красноречивое „Послание Вассиана к Иоанну III " и другие исторические памятники, народные песни и схоластическое духовное красноречие имеют точно такое же отношение к нашей словесности, как и памятники допотопной литературы, если бы они были открыты, к санскритской, греческой или латинской литературе? ...

Но стихотворения Ломоносова носят на себе отпечаток гения. Правда, у него и в них ум преобладает над чувством, но это происходило не от чего иного, как от того, что жажда к знанию поглощало все существо его. . . .

Что сказать о его сопернике, Сумарокове? Он писал во всех родах, в стихах и прозе, и думал быть русским Вольтером. Но при рабской подражательности Ломоносова, он не имел ни искры его таланта. Вся его художническая деятельность была не что иное, как жалкая и смешная натяжка.

. . . Громозвучные песни Державина были символом могущества. славы и счастия Руси; едкие и остроумные карикатуры Фонвизина были органом понятий и образа мыслей образованнейшего класса людей тогдашнего времени. . . .

Невозможно исчислить неисчислимых красот созданий Державина. Они разнообразны, как русская природа. но все отличаются одним общим колоритом: во всех них воображение преобладает над чувством, и все представляется в преувеличенных, гиперболических размерах. Он не взволнует вашей груди сильным чувством. не выдавит слезы из ваших глаз, но, как орел добычу, схватывает вас внезапно и неожиданно и на крыльях своих могучих строф мчит к солнцу и, не давая вам опомниться, носит по беспредельным равнинам неба. ...

Карамзин отметил своим именем эпоху в нашей словесности: его влияние на современников было так велико и сильно, что целый период нашей литературы от девяностых до двадщатых годов по справедливости называется периодом к а р а м 3 и н с к и м. . . .

Карамзин предположил себе целию - приччить, приохотить 
русскую публику к итению.

. . . Повести Карамзина приучили публику к чтению, многие выучились по ним читать; будем же благодарны их автору; но оставим в покое, даже вырвем их из рук наших детей, ибо они наделают им много вреда: растлят их чувство приторною чувствительностию.

Кроме сего, сочинения Карамзина теряют в наше время много достоинства еше и оттого, что он редко был в них искренен и естественек. Век фразеологии для нас проходит, по нашим понятиям фраза должна прибираться для выражения мысли или чувства; прежде мысль и чувство приискивались для звонкой фразы. . . .

Почти в одно время с Карамзиным выступил на литературное поприще и Дмитриев (И. И.). Он был в некотором отношения преобразователь стихотворного языка, и его сочннения, до Жуковского и Батюшкова, справедливо почитались образцовыми. Впрочем, его поэтическое дарование не подвержено ни малейшему сомнению. Главный элемент его таланта есть остроумие, посему „Чужой толк" есть лучшее его произведение. Басни его прекрасны; им недостает только народности, чтоб быть совершенными. В сказках же Дмитриев не имел себе соперника. Кроме сего, его талант возвышался иногда до лиризма, что доказывается прекрасным его произведением „Ермак” и особенно переводом, подражанием или переделкою (назовите как угодно) пьесы Гете, которая известна под именем „Размышления по случаю грома". . .

Крылов возвел у нас басню до пес plus ultra совершенства. Нужно ли доказывать, что это гениальный позт русский, что он неизмеримо возвышается над всеми своими соперниками? Кажется, в этом никто не сомневается. Замечу только, впрочем не я первый, что басня оттого имела на Руси такой чрезвычайный успех, что родилась не случайно, а вследствие нашего народного духа, который страх как любит побасенки и применения. Вот самое убедительнейшее доказательство того, что литература непременно должна быть народною, если хочет быть прочною и вечною! . . .

Озерова у нас почитают и преобразователем и творцом русского театра. Разумеется, он ни то, ни другое; ибо русский театр есть мечта разгоряченного воображения наших добрых патриотов. Справедливо, что Озеров был у нас первым драматическим писателем с истинным, хотя и не огромным талантом; он не создал театра, а ввел к нам французский театр, то есть первый заговорил истинным языком французской Мельпомены. Впрочем, он не бьл драматиком в полном смысле сего слова: он не знал человека. . . .

Появление Жуковского изумило Россию, и не без причины. Он был Колумбом нашего отечества: указал ему на немецкую и английскую литературы, которых существования оно даже и не подозревало. 
Кроме сего, он совершенно преобразовал стихотворный язык, а в прозе шагнул далее Карамзина: вот главные его заслуги. . . .

Многое из сказанного о Жуковском можно сказать и о Батюшкове. Сей последний решительно стоял на рубеже двух веков: поочередно пленялся и гнушался прошедшим, не признал и не был признан наступившим. Это бьл человек не гениальный, но с большим талантом. Как жаль, что он не знал немецкой литературы: ему немногого недоставало для совершенного литературного обращения. . . .

Батюшков, вместе с Жуковским, был преобразователем стихотворного языка, то есть писал чистым, гармоническим языком; проза его тоже лучше прозы мелких сочинений Карамзина. По таланту Батюшков принадлежит к нашим второклассным писателям и, по моему мнению, ниже Жуковского; о равенстве же его с Пушкиным смешно и думать. Триумвирату, составленному нашими словесниками из Жуковского, Батюшкова и Пушкина, могли верить только в двадщатых годах. . .

Мне остается теперь упомянуть еще о Мерзлякове, и я окончу весь карамзинский период нашей словесности. . . .

Мерзляков был человек с необыкновенным поэтическим дарованием и представляет собою одну из умилительнейших жертв духа времени. Он преподавал теорию изящного, и между тем эта теория оставалось для него неразгаданною загадкою во все продолжение его жизни; он считался у нас оракулом критики и не знал, на чем основывается критика; наконец, он во всю жизнь свою заблуждался насчет своего таланта, ибо, налисавши несколько бессмертных песен, в то же время написал множество од, в коих где-где блистают искры могущего таланта, которого не могла убить схоластика, и в коих все остальное голая риторика.

Князь Вяземский, русский Карл Нодье, писал стихами и прозою про все и обо всем. Его критические статьи (то есть предисловия к разным изданиям) бьли необыкновенным явлением в свое время. Между его бесчисленными стихотворениями многие отличаются блеском остроумия неподдельного и оригинального, иные даже чувством: многие и натянуты, как, например, „Как бы не так!” и пр. Но вообще сказать, князь Вяземский принадлежит к числу замечательных наших поэтов и литераторов. . . .

За карамзинским периодом нашей словесности последовал период пушкинский. продолжавшийся почти ровно десять лет. Говорю пушкинский, ибо кто не согласится, что Пушкин бьл главою этого десятилетия, что все тогда шло от него и к нему? . . .

В то время, то есть в двадшатых годах $(1817$ - 1824), у нас глухо отдалось эхо умственного переворота, совершившегося в Европе: тогда, хотя еще робко и неопределенно, начали поговаривать, что 
будто бы пяный дикарь Шекспир неизмеримо выше накрахмаленного Расина, что Шлегель будто бы знает об искусстве побольше Лагарпа, что немецкая литература не только не ниже французской, но даже несравненно выше; что почтенные гr. Буало, Батте, Лагарп и Мармонтель безбожно оклеветали искусство, ибо сами мало смыслили в нем толку.

Пушкинский период отличается необыкновенным множеством стихотворцев-поэтов: это решительно период стихотворства, превратившегося в совершенную манию. Не говоря уже о стихотворцах бездарных, авторах киргизских, московских и других пленников, авторах Вельских и других Евгениев под разными именами, сколько людей, если не с талантом, то с удивительною способностию, если не К поззии, то к стихотворству! . . .

Почти вместе с Пушкиным вышел на литературное поприще и г. Марлинский. Это один из самых примечательнейших наших литераторов. Он теперь безусловно пользуется самым огромным авторитетом: теперь перед ним все на коленах; если еще не все в один голос называют его русским Бальзаком, то потому только, что боятся унизить его этим и ожидают, чтобы французы назвали Бальзака французским Марлинским. . . .

Впрочем, меня ободряет в сем случае и то, что это страшное общественное мнение начинает мало-помалому приходить в память от оглушительного удара, произведенного на него полным изданием „Русских повестей и рассказов" г. Марлинского; начинают ходить темные толки о каких-то натяжках, о скучном однообразии и тому подобном. Итак, я решаюсь быть органом нового общественного мнения. Знаю, что это новое мнение найдет еще слишком много противников, но как бы то ни было, а истина дороже всех на свете авторитетов.

Тридцатый, холерный год был для нашей литературы истинным черным годом, истинно роковою эпохою, с коей начался совершенно новый период ее существования, в самом начале своем резко отличившийся от предыдущего. Но не было никакого перехода между этими периодами; вместо его был какой-то насильственный перерыв.

. . . Итак, тридиатым годом кончился или, лучше сказать, внезапно оборвался период пушкинский, так как кончился и сам Пушкин, а вместе с ним и его влияние; с тех пор почти ни одного бывалого звука не сорвалось с его лиры. Его сотрудники, его товарищи по художуственной деятельности, допевали свои старые песенки, свои обычные мечты, но уже никто не слушал их.

.. . Итак, настал новый период словесности. Кто же явился главою этого нового, этого четвертого периода нашей недорослой словесности? 
... Увы! Никто, хотя и многие претендовали на это высокое титло. Еще в первый раз литература явилась без верховой главы и из огромной монархии распалась на множество мелких, независимых одно от другого государств, завистливых и враждебных одно другому. . . .

Итак, я насчитал четыре периода нашей словесности: ломоносовский, карамзинский, пушкинский и прозачческо-народный: остается упомянуть еще о пятом, который начался с появления на свет первой части „Новоселья” и который можно и должно назвать смирдинским. Да, милостивые государи, я совсем не шучу и повторяю, что этот период словесности непременно должно назвать смирдинским. ибо А. Ф. Смирдин является главою и распорядителем сего периода. Все от него и всё к нему; он одобряет и ободряет юные и дряхлые таланты очаровательным звоном ходячей монеты; он дает направление и указывает путь этим гениям и полугениям, не дает им лениться, словом, производит в нашей литературе жизнь и деятельность. Вы помните, как почтеннейший А. Ф. Смирдин, движимый чувством общего блага, со всею откровенностию благородного сердца, объявил, что наши журналисты потому не имели успеха, что надеялись на свои познания, таланты и деятельность, а не на живой капитал, который есть луша литературы; вы помните, как он кликнул клич по нашим гениям, крякнул да денежкой брякнул и объявил таксу на все роды литературного производства, и как вербовались наши производители толпами в его компанию; вы помните, как великодушно и усердно взял он на откуп всю нашу словесность и всю литературную деятельность ее представителей! Вспомоществуемый гениями гг. Греча, Сенковского, Булгарина, барона Брамбеуса и прочих членов компании, он сосредоточнл всю нашу литературу в своем массивном журнале.

Какие же гении смирдинского периода словесности? Это гг. барон Брамбеус, Греч, Кукольник, Воейков, Калашников, Масальский. Ершов и мн. др. Что сказать о них? Удивляюсь, благоговею - и безмольвтвую!

The above statements should be compared with the more sober and less enthusiastic evaluation of nine years later (see below), especially concerning Derzhavin s works. Belinskii"s views of the "triumvirate" of writers. Zhukovskii, Batiushkov. and Pushkin. should be read together with Gogol's statements (pp. 19-22, below). The considerable achievement ascribed to Karamzin-Belinskii echoes commonly held views-miyht more appropriately be divided between N. I. Novikov and Karamzin as 1 . V. Kireevskii pointed out (see p. 8 above). It was in Novikov's circle that modern Russian was developed. Karamzin himself received an early training there. Belinskii also disregarded the stylistic refinement of Sumarokov's and Kheraskov's verses. which had already been praised by I. I. Dmitriev in his memoirs.

The poem by Goethe mentioned above is "Die Grenzen der Menschheit."

Concerning Boileau, Batteux, and La Harpe refer to Notes (p. 106). For Marmontel see above (p. 10). 
Eugenii Vel'skii (1828-29), one of many imitations of Pushkin's novel in verse, Evgenii Onegin.

A. F. Smirdin (1795-1857) was a well-known bookseller and publisher in St. Petersburg. He was personally acquainted with many Russian writers of the time who dedicated a Sbomik literatumykh statei to his memory after his death. Smirdin introduced the payment of regular honoraria, usually on a per line basis. In 1834 he founded the first of the "thick" journals, the Biblioteka dlia chteniia (edited by Senkovskii). Four years later he took over the publication of Syn otechestva (then edited by Polevoi and Grech). Smirdin's Rospis' Rossiiskim knigam dlia chteniia (1828-1832) is still one of the most important reference works for early 19 th-century Russian literature. Smirdin had a genuine interest in literature and began the systematic publication of the collected works of Russian authors in his series Polnoe sobranie sochinenii russkikh avtorov. Beginning with Lomonosov's works in 1846, Smirdin published the works of more than thirty-five Russian writers in approximately seventy volumes during the next ten years! His editions were of excellent quality and moderately priced, as Belinskii noted. A. V. Nikitenko (1805-1877), professor of literature and censor, author of a diary covering the years 1826-1857, said of Smirdin: "Smirdin istinno chestnyi i dobryi chelovek, no on neobrazovan i, chto vsego khuzhe dlia nego, ne imeet kharaktera. Nashi literatory vladeiut ego karmanom, kak arendoiu. On mozhet razorit'sia po ikh milosti. Eto bylo by nastoiashchim neschastiem dlia nashei literatury! Vriad' ij ei dozhdat'sia drugogo takogo beskorystnogo i prostodushnogo izdatelia. la ne raz predosteregal ego" (May 29, 1834). Belinskii himself held a much higher view of Smirdin than might appear from the above excerpt. In the miscellany Sto russkikh literatorov (1841) he said: "Chest' i slava g. Smirdinu!-Ego umnaia, blagonamerennaia deiatel'nost' daet zhizn' knizhnoi proizvoditcl'nosti, a sledovatel'no, i literature."

1843 В. Г. Белинскй, ,Сочннения Александра Пушкина” (Статья I). Отечественные записки, XXVIII, 6 (1843).

Хемницер, Богданович и Капнист тоже принадлежат уже к второму периоду русской литературы: их язык чище, и книжный риторический педантизм заметен у них менее, чем у писателей ломоносовской школы. Хемницер важнее остальных двух в истории русской литературы: он был первым баснописцем (ибо притчи Сумарокова едва ли заслуживают упоминовения), и между его баснями есть несколько истинно прекрасных и по языку, и по стиху, и по наивному остроумию. Богданович произвел фурор своею ,Душенькою”, современники были от нее без ума.

. . . Поззия Державина была первым шагом к переходу вообще русской поэзии от риторики к жизни, но не больше.

. . . С Карамзиным кончился ломоносовский период русской литературы, период тяжелого и высокопарного книжного направления, и весь период от Карамзина до Пушкина следует называть карамзинским.

. . . Карамзиным началась эпоха русской литературы.

. . . И вот почему Карамзину принадлежит честь основания новой эпохи русской литературы. Карамзин ввел русскую литературу в сферу 
новых идей, - и преобразование языка было уже необходимым следствием этого дела. Загляните в журналы, в романы, в трагедии и вообщє стихотворения эпохи, предшествовавшей Карамзину: вы увидете в них какую-то стоячесть мысли, книжность, педантизм и риторику, отсутстви: всякой живой связи с жизнию. Карамзин первый на Руси заменил мертвый язык книги живым языком общества. До Карамзина у нас, на Руси, думали, что книги пишутся и печатаются для одних „ученых”, и что неученому так же не пристало брать в руки книгу, как профессору танцевать. Оттого содержание книг, по тогдашнему мнению, должно было быть как можно более важным и дельным, то есть как можно более тяжелым и скучным. сухим и мертвым. Более всех подходил тогда к идеалу всликого поэта - Херасков, потому что бьл тяжел и скучен до невыносимости.

. . . Жуковский внес новый, живой, может быть сще более важный элемент в русскую поззию, чем элемент, внесенный Крыловым; Жуковский проложил себе собственный путь, в котором не било ему предшественников; муза Жуковского возросла и воспиталась на почве, в то время никому из русских не ведомой и не доступной. . . .

... В ..Отечественных записках” впервые было сказано, что заслуга Жуковского состоит в том, что он ввел в русскую поззию романтизм и что истинным роман тиком русским был совсем не Нушкин (как об этом кричали лет двадцать) , а Жуковский.' . .

Но перед цвадщатыми годами и в двадщатых годах текущего столетия Жуковский получил именно то значение, какое он всегда имел. Тогданняя молодежь, развившаяся под влиянием великих событий 1814 года, с жадностию бросилась на немецкую литературу, с которою Жуковский давно уже породнил русский ум и русскую музу. Все заговорили о романтизме, о новой теории поззии; все восстали против владычества псевдоклассической французской поэзии. В поэзии русской явились луна и туманы. уныние и грусть, смерть и гроб. Но в это время уже кончился карамзинский период русской литературы, и через десять лет сама история Карамзина сделалась предметом неумеренных и не всегда сираведливых нападок. Лучезарная звезда поэтической славы Жуковского вспыхнула и загорелась ярко уже в новом периоде русской литературы: тогда уже явился ІІушкин. и для Жуковского, еще во всей поре его деятельность, уже наставало потомство . . . ІІериод, означенного именем Жуковского, не было в русской литературе.

' 1 Belinskii refers to his article " Ocherki russkoi literatury' Nikolaia Pokvogo." 
1843 В. Г. Белинский, „Сочннения Александра Пушкиня” (статъя III) Отечественные записки, XXX, 9 (1843).

С 1813 года начали проникать в русские журналы темные слухи о каком-то романтизме. В ,Духе журналов" даже была переведена грозная статья против Августа Шлегеля, в защиту классического французского театра. Вместе с романтизмом стали закрадывать в наши журналы слухн о каком-то великом английском позте г-не Бироне, Бейроне или Байроне. ${ }^{1}$ В „Вестнике Европы” 1813 года было напечатано маленькое стихотворение Пушкина „На смерть Кутузова". 2 В „Российском музеуме, или Журнале европейских новостей” на 1815 год, издававшемся В. Измайловым, то и дело печатались лицейские стихотворения Пұшкина. ${ }^{3}$ Но в ученике и подражателе Державина, Жуковского и Батюшкова никто еще не предузнавал будушего великого поэта России. . . В 1820 году появилась в свет первая поэма Пушкина „Руслан и Людмила", а в журнале „Сын отечества" с этого времени стали появляться мелкие его стихотворения. . . . Тогда-то возгорелась ожесточенная война на перьях между классицизмом и романтизмом и начался крутой переворот в литературных понятиях и воззрениях. . . Карамзинский период русской литературы кончился ...

1. Belinskii made a chronological error. The journal Dukh zhurnalov was founded in 1815 and it was in the first volume (Nos. 3-5, and 7) that a critical review appeared which discussed August Schlegel's book Über dramatische Kunst und Literatur (Heidelberg, 1809 /On Dramatic Art and Literature//) and presented the Russian reader with lengthy excerpts from it. Byron was first mentioned the same year in the journal Rossiiskii muze. um $(1,1)$.

2. The poem was actually composed by Aleksei Pushkin, a relative of the famous poet.

3. Litsciskie stikhotvoreniia - poems written between 1814 and 1817 when Pushkin attended the Lycée in Tsarskoe Selo. 
1846 Н. В. Гоголь, „В чем же, наконец, существо русской поэзин и в чем eе особенность"

Выбранные места из переписки с друзьями (1847).

Восторг этот [по поводу реформ Петра] отразился в нашей поззии, или лучше - он создал ее. Вот почему поззия с первого стихотворения, появившегося в печати, приняла у нас торжествующее выражение, стремясь высказать в одно и то же время восхищение от света, внесенного в Россию, изумление от великого поприща, ей предостоящего, и благодарность царям, того виновникам. С этих пор стремление к свету стало нашим элементом, шестым чувством русского человека. . . .

Ломоносова называют отцом нашей стихотворной речи. Изумительно то, что начинатель уже явился господином и законодателем языка. Ломоносов стоит впереди наших поэтов, как вступление впереди книги. Его поззия - начинающийся рассвет. . . .

В эпоху Екатерины, которой царствование можно назвать блестящею выставкою первых русских произведений. . . . появился и поэт, Державин, с тою же картинно-величавою наружностию, как и все люди времени Екатерины, развернувшиеся в какой-то еше дикой свободе, со множеством недоконченного и не вполне отделанного в частях. как случается с теми произведениями. которые выставляются несколько торопливо на!оказ. . . У него выступило уже творчество. У него есть что-то еще более исполинское и парящее, нежели у Ломоносова. Недоумевает ум решить, откуда взялся в нем этот гиперболический размах его речн.

. . . Дико. громадно все; но где только помогла ему сила вдохновения, там весь этот громозд служит на то, чтобы неестественною силою оживить предмет, так что кажется, как бы тысячью глазами глядит он. Стоит пробежать его „Водопад”, где, кажется, как бы целая эпопея слилась в одну стремящуюся оду. В „Водопаде” перед ним пигмеи другие позты. Природа там как бы высшая нами зримой природы, люди могучее нами знаемых людей, а наша обыкновенная жизнь перед величественною жизнию, там изображенною, точно муравейник, который где-то далеко колышется вдали. О Державине можно сказать, что он - певец величия.

Наступил век Александра, опрятный, благопристойный, вылощенный. Французы стали вполне образщы всему. К чести, однако ж. верного позтического чутья нашего нужно сказать то, что в образец пошел один Лафонтен, затем именно, что был ближе к природе: Дмитриев: Хемницер и Богданович стали производить подобные ему в простоте творения, обрабатывая те же предметы. Русский язык вдруг получиз свободу и легкость перелетать от предмета к предмету - легкость, не знаемую Державину. Наместо оды стали пробовать все роды и формы 
поэзия. Дмитриев показал много таланта, вкуса, простоты и приличия во всем, которыми убил напышенность и высокопарность, нанесенные бездарными подражателями Державина и Ломоносова. Но поверхностная эпоха не могла дать богатого содержания нашей поэзии: одно общесветское стало ее предметом. . . .

В то время, когда Жуковский стоял еще в первой поре своего поэтического развития, отрешая нашу поззию от земли и существенности и унося ее в область бестелесных видений, другой поэт, Батюшков, как бы нарочно, ему в отпор, стал прикреплять ее к земле и телу, выказывая всю очеровательную прелесть осязаемой существенности. Как тот терялся весь в неясном еще для него самого идеальном, так этот весь потонул в роскошной прелести видимого, которое так ясно слышал и так сильно чувствовал. Все прекрасное во всех образах, даже и незримых, он как бы силился превратить в осязательную негу наслаждения. Он слышал, выражаясь его же выражением, „стихов и мыслей сладострастье". . . .

Два разнородные поэта внесли вдруг два разнородные начала в нашу поэзию; из двух начал вмиг образовалось третье: явился Пушкин. В нем середина. Ни отвлеченной идеальности первого, ни преизобнлия слалострастной роскоши второго. Все уравновешено, сжато, сосредоточено, как в русском человеке, который немногоглаголив на передачу ощушения, но хранит и совокупляет его долго в себе, так что от этого долговременного кошения оно имеет уже силу взрыва, если выступит наружу.

.. . Никто из наших поэтов не был еще так скуп на слова и выражения, как Пушкин, так не смотрел осторожно за самим собою, чтобы не сказать неумеренного и лишнего, пугаясь притворности того и другого. . . Пушкин дан был миру на то, чтобы доказать собою, что такое сам поэт, и ничего больше, - что такое поэт, взятый не под влиянием какого-нибудь времени или обстоятельств и не под условием также собственного, личного характера, как чедовека, но в независимости от всего; чтобы если захочет потом какой-нибудь высший душевный анатомик разъять и объяснить себе, что такое в существе своем поэт, это чуткое создание, на все откликающееся в мире и себе одному не имеющее отклика, то чтобы он удовлетворен был, увидев это в Пушкине. Одному Пушкину определено было показать в себе это независимое существо, это звонкое эхо, откликающееся на всякий отдельный звук, порождаемый в воздухе.

. . . Какая точность во всяком слове! Какая значительность всякого выражения! Как все округленно, окончено и замкнуто!. . .

И как верен его отклик, как чутко его ухо! Слышишь запах, цвет земли, времени, народа. В Испании он испанец, с греком грек, на Кавказе - вольный горец, в полном смысле этого слова; 
с отжившим человеком он дышит стариною времени минувшего; заглянет к мужику в избу - он русский весь с головы до ног: все черты нашей природы в нем отозвались, и все окинуто иногда одним словом, одним чутко найденным и метко прибранным прилагательным. именем.

. . . Он бросил стихи единственно затем, чтобы не увлечься по сторонам и быть проще в описаниях, и самую прозу упростил он до того, что даже не нашли никакого достоинства в первых повестях его. Пушкин был этому рад и написал „Капитанскую дочку”, решительно лучшее русское произведение в повествовательном роде. Сравнительно с „Капитанскою дочкою” все наши романы и повести кажутся приторною размазнею. Чистота и безыскусственность взошли в ней на такую высокую степень, что сама действительность кажется перед нею искусственною и карикатурною. В первый раз выступили истинно-русские характеры. . . .

Но влияние его было сильно на поэтов . . . Вокруг него образовалось их целое созвездие: Дельвиг, позт-сибарит, который нежился всяким звуком свосй почти эллинской лиры и, не выпивая залпом всего напитка поэзии, глотал его по капле, как знаток вин. присматриваясь к швету и обоняя самый запах; Козлов, гармонический поэт, от которого раздались какие-то дотоле неслыханные, музыкальносердечные звуки; Баратынский, строгий и сумрачный позт, который показал так рано самобытное стремление мыслей к миру внутреннему и стал уже заботиться о материальной отделке их, тогда как они еще не вызрели в нем самом; темный и неразвившийся, стал себя выказывать людям и сделался чрез то для всех чужим и никому не близким. Всех этих позтов возбудил на деятельность Пушкин. . . .

Из поэтов времени Пушкина более всех отделился Языков.

С появлением первых стихов его всем послышалась новая лира, разгул и буйство сил, удаль всякого выражения, свет молодого восторга и язык, который в такой силе, совершенстве и строгой подчиненности господину еще не являлся дотоле ни в ком. Имя Языков пришлось ему не даром: владеет он языком. как араб диким конем свонм, и еще как бы хвастается своею властию. Откуда не начнет период, с головы ли, с хвоста, он выведет его картинно, заключит и замкнет так, что остановишься пораженный. . . .

. . . Когда появились его стихи отдельною книгою, Пушкин сказал с досадою: „Зачем он назвал их: „Стихотворения Языкова! их бы следовало назвать просто: „Хмель!" ". .

Со смертию Пушкина остановилось движение поззия нашей вперед. Это, однако же, не значит, чтобы дух ее угаснул; напротив, он, как гроза, невидимо накопляется вдали; самая сухость и духота в воздухе возвещает его приближение. Уже явиіись и теперь люди не 
без талантов. Но еще все находится под сильным влиянием гармонических звуков Пушкина; еще никто не может вырваться из этого заколдованного, им очертанного круга и показать собственные силы. Еще даже не слышит никто, что вокрут него настало другое время, образовались стихия новой жизня и раздаются вопросы, которые дотоле не раздавались; а потому ни в ком из них еще нет самощветности. Их даже не следует называть по именам, кроме одного Лермонтова, который себя выставил вперед больше других и которого уже нет на свете. В нем слышатся признаки таланта первостепенного. . . .

$$
\text { ... В его сочинениях прозаических гораздо больше достоинства. }
$$

Никто еще не писал у нас такою правильною, прекрасною и благоуханною прозою. Тут видно больше углубления в действительность жизни готовился будущий великий живописец русского быта . . . Но внезапная смерть вдруг его от нас унесла. Слышно страшное в судьбе наших поэтов. Как только кто-нибудь из них, упустив из виду свое главное поприще и назначение, бросался на другос или же опускался в тот омут светских отношений, где не следует ему быть и где нет места для поэта, внезапная, насильственная смерть вызывала его вдруг из нашей среды. Три первостепенных поэта: Пушкин, Грибоедов, Лермонтов, один за другим, в виду всех, были похищены насильственною смертию, в течение одного десятилетия, в поре цветущего мужества, в полном развитии сил своих - и никого это не поразило: даже не содрогнулось ветреное племя! 


\section{THE EVOLUTION OF A NATIONAL LITERARY LANGUAGE}

\section{Introduction}

At the turn of the century Karamzin's stylistic innovations were becoming more and more popular. However, his cosmopolitan attitude, the facility with which he accepted foreign words in Russian, and the somewhat artificial quality of his subtle and adorned style were opposed by preromantic and neoclassicist authors alike. In 1803, Admiral Shishkov published his essay "Rassuzhdenie o starom i novom sloge rossiiskogo iayzka," which became the "bible" of the conservative and neoclassicist generation of writers and led to lengthy and at times violent polemics. Shishkov's book was endorsed by the government, yet attacked by sentimental and early romantic authors. Shishkov answered his opponents in another work published the following year, Pribavlenie $k$ sochineniiu, nazyvaemomu Rassuzhdeniem o novom $i$ starom... Here he gave a political interpretation to his earlier statements concerning the lack of purity in Russian literary style and the necessity of accepting Church Slavonic terms into literary Russian. His aim was, he said, to defend Russia against the influx of foreign revolutionary ideas and "tekh razvratnykh nravov, kotorymi noveishie filosofy obuchili rod chelovecheskii i kotorykh pagubnye plody, posle toliko proliianiia krovi, i ponyne eshche vo Frantsii gnezdiatsia" (p. 103). Two further points of dispute which arose in the course of the ensuing years were the nature of the Russian language and the role of writers in the evolution of a language. Shishkov maintained that Russian was a Slavic dialect. Early romantic writers protested against this attempt to subordinate Russian to Church Slavonic. M. T. Kachenovskii, editor of Vestnik Evropy, even argued that there had never been a Slavic language in a pure form. Shishkov also tried to minimize the significance of stylistic reforms undertaken by individual writers. Early romantic authors, conscious of the exalted position of the poet and writer in romantic esthetics, disputed Shishkov's views.

The polemic reached another climax towards the end of the first decade. Shishkov attacked his opponents in a new work, Perevod diukh statei iz Lagarpa s primechaniiami perevodchika (Sankt-Peterburg, 1808), accusing them of atheism and a lack of cultural refinement. Again he linked the new style to revolutionary aspirations. Shishkov was attacked with great skill and satire by Batiushkov in "Videnie na beregakh Lety" and by D. V. Dashkov in a critical essay in Tsvetnik $(11-12,1810)$, in which he criticized Shishkov's translation. Shishkov answered his critic in Rassuzhdenie o krasnorechii sviashchennogo pisaniia (1811). V. L. Pushkin continued the attack on Shishkov 
with a pamphlet, Dva poslaniia (Sankt-Peterburg, 1811), as did Dashkov with his brochure $O$ legchaishem sposobe vozrazhat' na kritiki (Sankt-Peterburg, 1811). In the same year a literary society was founded in which Shishkov gathered his adherents, Beseda liubitelei russkogo slovo. The polemic continued during the next five to six years. The dissolution of the Beseda group in 1817 brought an end to it. Reflexions of the polemic can be found in the works of V. L. Pushkin, Shakhovskoi, Batiushkov, Viazemskii, Zhukovskii and A. S. Pushkin. In 1816, Shishkov's opponents founded their own society, Arzamas, which satirized and ridiculed the Beseda group. It should be noted that even at the time of the most heated controversy the lines were not sharply drawn and there were writers sympathetic to both the Beseda and Arzamas groups, among whom were Derzhavin, Krylov, and Gnedich.

In the early twenties the polemic once again arose when a group of younger writers (Katenin, Griboedov, Zhandr, and Kiukhel'beker) expressed their recognition of the positive features of Shishkov's programme, stressed the need to keep the language pure, to use Church Slavonic expressions moderately, and themseives attacked the overly ready acceptance of West European influences (cf. pp. 31-34).

Katenin had expressed his opposition to Karamzin's and Zhukovskii's style by his transiation of Bürger's ballad "Lenore" (translated as "Ol'ga" in 1816) which was meant to counteract the influence of Zhukovskii's earlier translation ("Liudmila," 1808).

In the second half of the 1820's the polemic receded and new emphasis was placed on the further development of a national Russian literary language drawing from the reservoir of popular idiom ("prostonarodnyi iazyk") and only sparsely using neologisms formed from Western roots. 
1800 Н. М. Карамзнн, Пантеон российских авторов (Москв8, 1802). .

Проза Ломоносова вообще не может служить для нас образцом; длинные периоды его утомительны, расположение слов не всегда сообразно с течением мыслей, не всегда приятно для слуха; . . .

1803 А. С. Шاншков, Рассуждение о старом и новом слоге российского языка (Санкт-Петербург, 1803)

. . Кто виноват в том, что мы во множестве сочиненних и переведенных нами книг имеем весьма немногое число хороших и подражания достойных? Привязанность наша к французскому языку и отвращение от чтения книг церковных.

. . . Прилежное чтсние российских книг отнимет у нынешних писателей драгоценное время читать французские книги. Возможно ли, скажут они с насмешкою и презрением, возможно ли трогательную Заиру занимательного Кандида, милую Орлеанскую девку променять на Пролог, на непонятный Несторов Летописец? Избегая сего труда, принимаются они за самый легкий способ, а именно: одни из них безобразят язык свой введеннем в него иностранных слов, таковых, например, как: моральный. эстетический, эпоха. сиена. гармония. акция, знтузиязм, катастрофа и тому подобных. Другие из русских слов стараются делать не русские, как например: вместо будущее время, говорят будущность.

... Третьи французские имена, глаголы и целые речи переводят из слова в слово на русский язык; самопроизвольно принимают кх в том же смысле из французской литературы в российскую словесность, как будто из их службы офицеров теми ж чинами в нашу службу, думая, что они в переводе сохранят тож знаменование, какое на своем языке имеют.

. . . По мнению нынешних писателей, великое было бы невежество, нашед в сочиняемых ими книгах слово переворот, не догадаться, что оное значит revolution или по крайней мере, revolt.

. . . Многие ныне, почитая невежество свое глубоким знанием и просвещением, презирают славенский язык . . . 
. . . Мы думаем быть Оссиянами и Стернами, когда, рассуждая о играющем младенце, вместо: как приятно смотреть на твою молодость! говорим: коль наставительно взирать на тебя в раскрывающейся весне твоей! Вместо: луна светит: бледная геката отрахсает тусклые отсветки. Вместо: окна заиндевели: свирепая старица разрисовала стекла. Вместо: Машенька и Петруша, премилые дети, тут же с нами сидят и играют: Лолота и Фанфан, благороднейщая чета, гармонируют нам. . . . Вместо: деревенским девкам навстречу идут цыганки: пестрые толпы сельских ореад сретаются с смуглыми ватагами пресмыкающихся фараонит. . . .

... Простой, средний и даже высокий слог российский, конечно, не должен быть точный славенский, однако ж сей есть истинное основание его, без которого он не может быть ни силен, ни важен. Нет, конечно, никакой нужды, рассуждая о премудрости, говорить: лучще бо сию куповати: но что препятствует нам сказать о ней: в деснице ее долгота жизни; в шуйце ее богатство и слава; от уст ее исходит правда; закон же и милость на языке своем носит; все пути ее добры и все стези ее мирны?

. . . Мнение, что славенский язык различен с российским и что ныне слог сей не употребителен, не может служить к опровержению моих доводов; я не то утверждаю, что должно писать точно славенским слогом, но говорю, что славенский язык есть корень и основание российского языка; он сообщает ему богатство, разум, силу, красоту. И так в нем упражняться и из него почерпать должно искусство красноречия.

. . . Прилично и нужно наблюдать равенство слога, то есть не смешивать низких слов с высокими, шутливых речей с важными, замысловатых выражений с весьма простыми. . . .

A. S. Shishkov (1754-1841) grew up in the 1760's and 1770's when Lomonosov's stylistic system concerning the use of low, middle, and high style in the various genres of classicist literature was still generally recognized as obligatory. Having been educated in a strictly religious milieu, he developed considerable interest in Old Church Slavonic and wrote several "philological" treatises dealing with the relationship between Old Church Slavonic and the Russian language of his day. Initially, he maintained that both were identical and attempted to replace neologisms and borrowings from foreign languages with Old Church Slavonic equivalents. His efforts were directed chiefly against the stylistic reforms of Karamzin in whose work the Lomonosovian middle style had merged with the language of the salon. Karamzin had not hesitated to coin neologisms and take over French expressions, and his followers often exaggerated this feature. As Shishkov's reference to Ossian and Sterne indicates, he was not fond of the sentimental movement. His criticism of such stylistic excesses as on overly intricate, refined, and metaphoric style was justified to a degree. Andrei Turgenev and his literary circle of 1801 (Druzheskoe literaturnoe obshchestvo) and the Vol'noe obshchestvo liubitelei slovesnosti, nauk $i$ khudozhestv (founded 1801) expressed similar views. 1. M. Born, a prominent member of the latter group, said in his manual of Russian literature:

Какой ненсчерпаемый нсточннк имсем мы в славянских книгах! Сколь богат, снлен и благозвучен язык славянороссияския! Не быв прнстрастен к боязливоһ̆ очистке (purism) нельзя, однакож, без некоего негодовання на нерадивость многих переводчиков видеть в сочннениях и переводах их не только худосложенныс новые слова. но н иелые предложення свокству языка вовсе противныс . . . (Краткое руководство к российской словесности. 1808). 
1803 П. И. Макаров, „Критика на кпну под названнем Рассукдения о старом и новом слоге россияского языка" "

Московский Меркурий. IV, 12 (1803).

. . . Нет вещи, нет и слова; нет понятия, нет и вырахения, посредством которого можно бы то понятие сообщить другому человеку. После Ломоносова мы узнали тысячи новых вещей; чужестранные обычаи родили в уме нашем тысячи новых понятий, вкус очистился; читатели не хотят, не терпят выражений, противных слуху; более двух третей русского словаря остается без употребления: что делать? Исхать новых средств изъясняться. Удержать язык в одном состоянии невозможно: такого чуда не бывало от начала света. . . . Должно ли винить Феофана, Кантемнра, Ломоносова, что они первые удалились от своих предшественников, которых сочияитель „Рассуждения о слоге” предлагает нам теперь в образец? Язык следует всегда за науками, за художествами, за просвещением, за нравами, за обычаями. Придет время, когда и нынешний язык будет стар: шветы слога вянут, подобно всем другим цветам. В утешение писателю остается, что ум и чувствования не теряют своих приятностей и достигают самого отдаленного потомства. Красавищы третьего века не станут, может быть, искать могилы бедной Лизы; но и в двадщать третьем веке друг словесности, любопытный знать того, кто из 400 лет прежде очнстил, украсил наш язык и оставил после себя имя, любезное отечественным благодарным музам, друг словесности, читая сочинения Карамзина, всегда скажет: „Ок имел душу, он имел сердиe!".

. . . Все языки составились один из другого обменом взаимным. .. . Почему нам одним не занимать? Мы ли первые начали? Мы застали русский язык, наполненный словами греческими, латинскими, татарскими, немещкими. . . . Безобразит ли теперь наш язык немещкое слово кучер? Какой поселянин не разумеет его? Или, лучше сказать, какого поселянина уверишь, что оно не коренное русское? Некоторые чужестранные слова совершенно необходимы; лишы только не должно пестрить языка без крайней осторожности.

. . . Сочинитель „Рассуждения о слоге” не любит даже и настоящих русских слов, если нет их в книгах старинных; не любит даже таких, которые включены в Словарь Академии, 1 приняты всеми и употребительны равно в слоге высоком и в обыкновенном разговоре, например трогательно, утонченный.

. . . В отношении к обычаям и понятиям мы теперь совсем не тот народ, который составляли наши предки; следственно, хотим сочинять фразы и производить слова по свонм поятиям нынешним, умствуя как французы, как немщы, как все нынешние просвешенные народы. Неужели сочинитель, для удобнейшего восстановления старинного языка, 
хочет возвратить нас к обычаям и к понятиям старинным? ... Мы не смеем остановиться на сей мысли; однако ж, что иное подумать, приводя все его рассуждения в систему? . . .

P. I. Makarov (1765-1804), the editor of the short-lived journal Moskovskii merkurii (1803), was a sentimental author and critic. The greater part of the material in his journal came from his own pen. The Moskovskii merkurii was one of the first Russian journals to have a special section of critical reviews. The above criticism of Shishkov represents the sentimental attitude and led to continued literary polemics. Makarov's assumption, "iazyk sleduet vsegda . . . za nravami..." was taken up by Shishkov in his later writings when he linked the karamzinian style to the supposedly declining morality of Russian writers. As in Shishkov's statement above, we see also in Makarov's lines that the focal point of the polemic was not so much philological but literary, centering around the concepts of sentimental literature, especially in its late form as sentimental estheticism.

The Severnyi vestnik (Part I, No. 1 [1804], pp. 17-28) published a Pis'mo ot neizvestnogo probably written by Kachenovskii, which was also critical of Shishkov, yet shared the latter's views concerning the closeness or identity of Russian and Old Church Slavonic. The Severnyi vestnik was closely allied to the Vol'noe obshchestvo (see p. 29).

'Makarov refers to the Slovar' Akademii Rossiiskoi (in six parts) which appeared in St. Petersburg between 1789 and 1794. A second edition was published between 1806 and 1822.

1805 Г. Р. Державин, [ Писъмо И. И. Дмитрневу от 10 января 1805 г.] Сочинения Державина, VI (Санкт-Петербург, 1871).

Но как бы то ни было, предвижу я между Москвою и Петербургом великую литературную бурю. Твердят уже здесь на театре русского lilтерн; тут-то полетят громы и молния; штыки нового и старого стиля засверкают, меж коими я, прижавшись в уголку, с истинным почтением пребываю и проч.

A. A. Shakhovskoi's (1777-1846) comedy Novyi Stern (publ. 1807) parodied the exaggerated tearfulness of late sentimentalism. The performance of the play in $1805 \mathrm{ked}$ to extensive polemics. Derzhavin participated in the conservative Besedo group in 1807, but like Gnedich, occupied a middle-of-the-road position in the current conflict between the "old" and the "new" styles.

1810 А. С. Шншков, Рассуждение о красноречии священного писания ... . и'Разговоры о словесности

(Санкт-Петербург, 1811).

Какое намерение полагать можно в старании удалить нынешний язык наш от языка древнего, как не то, чтоб язык веры, став невразумнтелен, не мог никогда обуздывать языка страстей? . . .

Ежели 6 воспитание наше было такое, чтоб мы от самого детства своему языку основательно учились, своим языком говорили, свои книги читали, тогда бы разговорный язык стал возвышаться и чиститься от книжного, на разуме основанного, а не книжный упадать и 
портиться от разговорного, невежественного языка. . . .

Мы бросились на новейшие иностранные языки и, переводя с них, стали придерживаться их свойствам. Чего у них в языке нет, того уже и мы в сочинениях своих употреблять не смеем. Сие излинее подражание им отводит нас от собственных красот языка нашего и, стесняя пределы оного, служит более ко вреду, нежели к пользе словесности.

Shishkov's Rassuzhdenie was attacked by D. V. Dashkov (1788-1839) and V. L. Pushkir (1770-1830). Shishkov answered his critics in a Pribavlenie $k$ Rassuzhdeniiu... (1812).

\author{
М. Т. Кауеновскнй, --- \\ Вестник Европы, 12 (1811).
}

Оставияйся в книгах духовных славенский язык отделен от нынешнего русского несходством некоторых слов и разностию в спряжениях и даже в правилах синтаксиса. Без всякого сомнения русский язык есть отрасль славенского; но теперь он уже в таком состояния, что приличнее называть его языком, а не наречием. На нем издаются законы: на нем написаны многие книги; как же можно сказать, что он не существует, и как можно называть его наречием. тогда как сам он уже имеет множество местных наречия? Ежели так, то ни один из нынешних европейских языков не существует, ибо все они произошли от древних и из них составились. Было бы очень странно, когда б уверять стали, что у италянцев и французов нет языка и что те и другие говорят наречием или слогом.

M. T. Kachenovskii (1775-1842), then editor of the prestigious journal Vestnik Evropy (founded by Karamzin in 1802), reviewed Shishkov's Priballenie $k$ Razgovoram... in a series of articles in his journal (No. 6, pp. 117-130; No. 7, pp. 195-217 (18121) where he reaffirmed his belief stated a year earlier that Russian was not a dialect but a lang. uage in its own right. Batiushkov, who had listened to a lecture by Kachenovskii, wrote to A. I. Turgenev (Oct. 14, 1816):

Он утверждает, что Библия писана на сербском диалекте; то же, думаю, говорит и Карамзин. А славенския̆ язык вовсе изчез; он чнстый и не существовал, может быть ибо под именем Славен мы разумели все поколения славянскне. говорившие разными наречнями, весьма отличными одно от другого. Он разбудит славенофилов. Если правду говорит Каченовския̆. то каков Шишков с партией! . . . Варвары, они изказили язык наш славенщизною! (Сочинения. Т. 3, С-П.1886.) 
1814 Н. И. Гнедич, „Рассуждение о прнчннах, замедляюиих развитие нашен словесности"

Описание торжественного открытия имп. Публичной библиотеки, бывшего генваря 2 дня, 1814 года (Санкт-Петербург, 1814).

Но я упустил бы важнейшее в предмете моих мыслей, если б оставил без исследования, какое влияние имеет общество на образование языка и какой вред делаем мы нашей словесности в обществах не говоря по-русски.

Язык поэзии всех почти народов есть язык особенный, а у нас тем более, что не только формами, но и самою сушностью он отличается от языка общественного. Сущность сию дает ему наш язык славенский, давно образованный и утвержденный, а для составлення форм поэтических нужны только были дарования, они нам дали образщы для многих родов, и образцы превосходные для поэзии высокой. Следственно, на успехи нашего языка стихотворного общество менее имеет влияния, чем на успехи прозы.

. . . Язык богатеет и утверждается, если им говорят: употребление дает всему силу, а тонкость в словах, легкость в оборотах и приятность в выражениях образующне прекрасный язык гражданский, составляет одна разборчивость и вкус общества, ибо там вежливость украшает разговоры, там метафоры более верны, сравнения более благородны, шутки более тонки. И поелику речь есть одежда мысли, там требуют от нее приличия вкуса и той приятности в самом произношении, которая, лаская уху, пленяет сердие. . . .

Чему ж мы удивляемся? Кого обвиняем в малых успехах нашей словесности? На кого жалуемся, что язык наш до сих пор не обработан? Что некоторые наши писатели прибегают до сих пор к словам и выражениям, противным вкусу избранного общества? Куда идти? Где искать новых слов и выражений для новых вещей и понятий? Где слышать разговор наших гращий, украшенный прелестью произношения? Где найти язык, образованный вежливостью и вкусом? В обществе? Там этого ничего нет, там мы услышим, увидим и найдем одно иностранное. И вот, может быть, причина сему невольному введению слов иностранных, выражений и оборотов, языку нашему не свойственных, вот истинная причина, что у нас нет еще языка для комедин, что не все еще прозаические слоги свойственны гению языка русского, и поелику дирование писателей блистает во всем совершенстве на таком только языке, который утвержден совершенно, то вот, наконец, причина, что мы еще весьма бедны образцами гражданского красноречия. 
N. I. Gnedich's (1784-1833) speech, a "dekliaratsiia neoklassitsizma" (N. I. Mordov. chenko, Russkaia kritika pervoi cherverti XIX v. [M.-L., 1959], p. 133), reflects his independent position. Although he was a member of Shishkov's circle Besedo, he was simultaneously a friend of Zhukovskii and Batiushkov. His speech attempted to counteract the excesses of sentimentalism, preserve the purity of the language, and create more monumental literary forms than those used by sentimentalists.

1821 А. С. Шишков (?), „Письмо”

Соревнователь просвещения и благотворения, XIII , 4 (1821).

1. . . . Богатство или преимущество русского языка состоит именно

в логическом и метафизическом составе его, разумея под сими

словами . . . чистый ум, порождавший в нем каждое слово по сообра-

жению подобий, свойств и качеств означенных ими вещей. 2. [Писатели суть] творцы сочнненнй своих, а не языка, который есть плод веков и народа. 3. . . . Со стороны недостатка в терминах наук и художеств должны мы скорее на самих себя пенять, нежели на язык свой: у нас нет философских слов, нет номенклатуры ученой - да разве чужеземцы сию номенклатуру не из слов языка своего составили? Разве они посылали за нею на луну, куда мы посылать не можем?

1821 А. А. Бестужев, [ Ответ на пнсьмо шинкова ] Соревнователь просвещения и благотворения, XIV, 5 (1821).

Я думаю, что писатели суть творшы языка (без коего нельзя и сочинять). а язык доставляет бессмертие времени и народу . . . И так этот плод веков и народов может иногда рождаться в одно десятилетие от одного человека.

When Shishkov read a speech at the Beseda liubitelei russkogo slor'a (1821) on the topic "O drevnosti i prevoskhodstve russkogo iazyka pred drugimi $v$ zvukopodrazhatel'nom i logicheskom otnosheniiakh," Bestuzhev reacted against Shishkov's exaggerated claims in an article in Sorevnovatel' prosveshcheniia i blagotvoreniia (No. 2, 1821) where he pointed out the indebtedness of the world for philosophical terms to geniuses such as Leibniz, Newton, and Buffon. The polemic continued with another exchange of statements. In support of his position, Bestuzhev quoted a speech by Karamzin (Dec. S, 1818): "...Slova ne izobretaiutsia Akademiiami, oni rozhdaiutsia vmeste s mysliami i v upotreblenii iazyka ili v proizvedeniiakh talanta, kak schastlivoe vdokhnovenie."

П. А. Катеннн, „Пнсьмо к издателю С. О.”

Сын отечества. 13 (1822).

Знаю все насмешки новой школы над славянофилами, варягороссами и проч.; но охотно спрошу у самых насмешников: каким же языком нам писать эпопею, трагедию или даже важную, благородную прозу? Легкий слог, как говорят, хорош без славянских слов; пусть так, но в 
легком слоге не вся словесность заключается; он даже не может занять в ней первого места; в нем не существенное достоннство, а роскошь и щегольство языка. Исключительное предпочтение всего легкого довело до того, что хотя число стихотворцев (время прозы еше не настало) и умножилось, а число творений уменьшилось. Перечтите собственный ваш список и вы увидите, что в последнее время одни трагедии Озерова не мелкие стихотворения. Конечно, есть люди с дарованием и способностями: отчего же они не пользуются ими и не трудятся над предметами, достойными внимания? Не от того ли, что почти все критики, а за ними и большая часть публики расточают им вредную похвалу за красивые безделки и тем отводят их от занятий продолжительных и прочных? Сравните старых наших писателей с нынешними: оставя природный дар в стороне, вы найдете в первых истинную любовь к искусству, степенное в нем упражнение, трудолюбие и душевное старание об успехе языка и поззин; они боролись с большими трудностями; каждый в своем роде должен был создавать язык, и заметьте мимоходом, что которые более держались старого, менее устарели; самые неудачи их могут еще служить в пользу их последователям, но последователей нет.

See pp. 33, 39.

1822 А. А. Бестужев, „Замечания на критику, помещениую в 13-номере ,Сына отечества' касатељно ,Oпыта краткой историн русской литературы" "

Сын отечества, 20 (1822).

Легкий слог вопреки мнению $r$. Катенина, должен употребляться и в важных сочинениях, если хотим дать им вес, не делая их увесистыми. Впрочем, легкие пьесы не чуждаются выражений высоких. Батюшков, Жуковский, Пушкин в самых эротических сочинениях употребляли слова: денница, трикраты, скудель и т. п., потому что гений украшает все, до чего ни коснется. Другой пишет то же, но слог у него пуст, а все не легок.

деннице - утренняя заря; скудель - сосуд.

1822 П. А. Катеннн, „Ответ на ответ”

Сын отечества, 18 (1822).

Некоторые из последователей Ломоносова, Петров, Костров, в наше 
время к. Щихматов, Гнедич и другие, старались еще ближе подойти к языку церковному, и обогатили свои творения множеством слов и оборотов, которые теперь сделались нашею собственностию; пороки их вредят только им, а труды их полезны для всех. Весьма вероятно, что и сам Ломоносов не остановился бы на половине дороги, если б не опасался слишком оскорбить вкус тех людей, которые в его время думали, как ныне r. Греч, ненавидели славенщизну и восхищались чистым русским языком Сумарокова. Напрасно силятся защитники нового слога беспрестанно смешивать в своих нападениях и оборонах, высокий слог любителей церковных книг с обветшалым слогом многих из наших старых сочинителей, которые напротив держались одннаковых с новыми правил, и только от того не совсем на них похожи, что разговорный язык в скорое время переменился. Вот истинная причина чудесного упадка иных писателей: что тогда казалось сильно, просто, мило, выходит нынче тяжко, подло, смешно; тех, кого еще десять лет тому назад равняли с Гомером и Виргилем, уже не смеют в история литературы назвать поэтами! Либо мы уверились, что язык наш теперь доведен до высшей степени совершенства, либо пример, приведенный мною, должен многих испугать и открыть им глаза.

The three excerpts above illustrate the polemic between the moderate adherents of Shishkov's view, such as Katenin, Griboedov, Zhandr, and Kiukhel'beker (see also p. 39.) and the adherents of Karamzin's style such as Bestuzhev and Grech. Cf. Kiukhel'beker's statements of 1824 and 1828 (pp. 34, 182f. below). Note also Pushkin's view, which in many ways seems to be close to that of the "young archaists" like Kiukhel'beker.

1823 А. С. Пушкин, [ Пнсьмо Вяземскому от декабря, 1823 г ] Полное собрание сочинений, ХІІІ (Москва-Ленннград, 1937).

Я не люблю видеть в первобытном нашем языке следы европейского жеманства и французской утонченности. Грубость и простота более ему пристали.

1824 В. К. Кюхельбекер, „О направленин нашей поэзни, особенно лирнческой, в последнее десятилетие"

Мнемозина, II (1824).

Из слова же русского, богатого и мощного, силятся извлечь небольшой, благопристойный, приторный, искусственно тоший, приспособленный для немногих язык, un petit jargon de coterie. Без пощады изгоняют из него все речения и обороты славянские и обогащают его архитравами, 
колоннами, баронами, траурами, германизмами, галлищизмами и барбаризмамк. В самой прозе стараются заменить причастия и деепричастия бесконечными местоимениями и союзами. О мыслях и говорить нечего.

1825 А. С. Пушкин, „О преднсловия Г-на Лемонте к переводу басен И. А. Крылова"

Московский телеграф, V, 5 (1825).

Как материал словесности, язык славяно-русский имеет неоспоримое превосходство пред всеми европейскими: судьба его была чрезвычайно счастлива. В XI веке древний язык вдруг открыл ему свой лексикон, сокровищницу гармонии, даровал ему законы обдуманной своей грамматики, свои прекрасные обороты, величественные речи; словом, усыновил его, избавя таким образом от медленных усовершенствований времени. Сам по себе уже звучный и выразительный, отселе заемлет он гибкость и правильность. Простонародное наречие необ. ходимо должно было отделиться от книжного, но впоследствии они сблизились, и такова стихия, данная нам для сообщения наших мыслей.

1828 В. К. Кюхелбекер, [Дневннк]

Дневник В. К. Кюхельбекера (Ленннград, 1929) , стр. 88.

Мы. кажется, шли с 1820 года совершенно различными дорогами, он [А. С. Пушкин] всегда выдавал себя (искренно ли или нет - это иное дело!) за приверженца школы так называемых очистителей языка, а я вот уже 12 лет служу в дружине славян под знаменем Шишкова, Катенина, Грибоедова, Шихматова.

1828 А. С. Пушкн,, [О „Евгенкн Онегине” и крнтиках романа] Полное собрание сочинений, II (1949).

Кстати о Крылове. Вслушивайтесь в простонародное наречие, молодые писатели - вы в нем можете научиться многому, чего не найдете в наших журналах.

... Изучение старинных песен, сказок и т. п. необходимо для совершенного знания свойств русского языка. Критики наши напрасно ими презирают. ... 
. . Разговорный язык простого народа не читающего иностранных книг и, слава Богу, не выражающего, как мы, своих мыслей на французском языке достоин также глубочайших исследований. Альфиеры изучал итальянский язык на флорентинском базаре: не худо нам иногда прислушиваться к московским просвирням. Они говорят удивительно чистым и правильным языком.

Vittorio Alfieri (1749-1803). Outstanding Italian dramatic author of the 18 th century. Prosvirnia - (female) baker of communion bread as used in church services.

1833 А. С. Пушкин, „Сочннення и переводы в стихах Павла Катеннна" Литературные прибавления к „Русскому инвалиду", 26 (1833).

Таким образом. быв один из первых апостолов романтизма и первый введши в круг возвышенной поэзии язык и предметы простонародные. он первый отрекся от романтизма и обратился к классическим идолам, когда читающей публике начала нравиться новизна литературного преобразования.

Первым замечательным произведением r-на Катенина был перевод славной Биргеровой „Леноры”. Она была уже известна у нас по неверному и прелестному подражанию Жуковского, который сделал из нее то же, что Байрон в своем „Манфреде” сделал из „Фауста”: ослабил дух и формы своего образца. Катенин это чувствовал и вздумал показать нам „Ленору” в энергической красоте ее первобытного создания; он написал „Ольгу”. Во сия простота и даже грубость выражений, сия сводочь, заменившая воздушную иепь теней. сия виселица вместо сельских картин, озаренных летнею луною, неприятно поразили непривычных читателей, и Гнедич взялся высказать их мнения в статье, коей несправедливость обличена была Грибоедовым. После „Ольги” явился „Убийца", лучшая, может быть, из баллад Катенина. Впечатление, им произведенное, было и того хуже: убийца, в припадке сумасшествия, бранил месяц, свидетеля его здодеяния, плешивым! Читатели, воспитанные на Флориане и Парни, расхохотались и почли балладу ниже всякой критики.

In 1816, Katenin published his version of Bürger's ballad "Lenore," which he entitled "Ol'ga." The same ballad had already been translated in the sentimental mood by Zhukovskii in 1808 as "Liudmila." Katenin considered Zhukovskii's translation not Russian enough and therefore wrote his own version which incorporated many colloquialisms and crude expressions. Katenin was attacked by Gnedich (Syn otechestva, No. 27, 1816), and defended by Griboedov (Syn orechestva. No. 30, 1816). Note that Pushkin 
began work on his poem Ruslan $i$ Liudmila the year following the polemic and there is reason to assume that he may have intended his poem to answer the questions raised by the polemic. Pushkin ridiculed features of Zhukovskii's style.

Jean-Claris de Florian (1755-1794). Author of sentimental idyls, songs, comedies, and pastoral novels popular in Russia in the late 18th century.

Evariste-Desire de Forge, Vicomte de Parny (1753-1814). Author of sensual, sentimental-romantic love poems.

Compare Zhukovskii's lines,

Сльшут шорох тихих тенеи:

В час полуночньх видения,

В дыме облака,толпоя,

Прах оставя гробовоя

С поздним месяца восходом,

Легким, светлым хороводом

В щепь воздушную свились; . . .

to those by Katenin,

\author{
Казни столп; над ним за тучей \\ Брезжит трепетно луна; \\ Чьея-то сволочи летучея \\ Пляска вкруг его видна. \\ . . \\ Сволочь с песныо заунывноя \\ Понеслась за седоком. . .
}

Pushkin also refers to another ballad by Katenin ("Ubiitsa," 1815), particularly to the lines where the murderer addressed the moon, the sole witness of his deed:

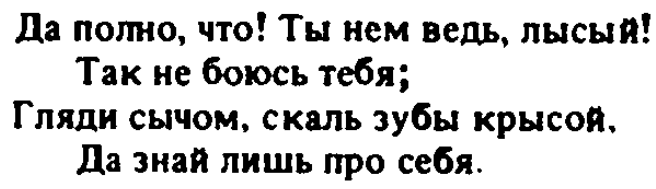

1836 Н. И. Надеждин, „Европензм и народность в отношення к русской словесности"

Телескоп. XXXI(1836).

. . . Наш простой народ . . . не примет в свою речь ни одного чужого слова, не изломав его на свой манер, не окрасив в русский щвет волею и неволею; у него „ресторация" превращена в ,,растеряцию”, „экзекуиия" переводится „секуцией". Итак в нем, в его поговорках и предисловиях, в его песнях, в его остротах и прибаутках надо видеть своеобразное, неискаженное, натуральное биение пульса живого русского языка. Мы, дышащие чужим воздухом, вращающиеся в чужой атмосфере, не только читающие, но и думающие большей частью на чужих языках, мы часто без ведома и против воли перенимаем чужяе обороты, теряем даже способность различить, что русское и что не русское, прививное. Но народ не знает ничего, кроме своего родного языка, завещанного ему от предков; он говорит, как говаривали деды и отцы, 
повторяет те же пословицы, поет те же песни. Может быть побоятся унизить язык, низведши его в формы простонародные; может быть, подумают, что зти формы так обношены, так загрязнены, что употреблять их то же, что обуваться в лапти и онучи! - Опасение несправедливое! . . . Разве нет у нас блистательных примеров возведения простонародного языка, даже и в материальном отношении, на высшую степень литературного достоинства? . . У Укажу только на басни Крылова и на романы Загоскина!

... Таковы мысли мои о возможности и условиях русского языка, который бы имел свежесть, свободу и естественность живого разговора и в то же время был бы способен к искусственному, книжному, литературному употреблению! - Так можно создать изящный, народный язык; так можно создать живую, народную литературу!

N. 1. Nadezhdin (1804-1866) began his literary career in the late 1820's with attacks against pseudoromanticism and pseudoclassicism (both terms were apparently coined by him). In 1830, he published excerpts from his dissertation on the origin and nature of romantic poetry where he identified it with medieval West European literature. For his own time he demanded a synthetic art that would unite classical with medieval literature. Nadezhdin has been called a distant forerunner of realistic literary views.

I. A. Krylov (1768-1844) wrote about 200 fables, which, after their original publication in book form in 1809 ( 2 nd edition 1815-16, 3rd edition 1819; 4th edition 1825; new and enlarged edition 1831, published in a second edition by Smirdin in 1834), became the model for a forceful and natural speech, close to the language spoken by the average Russian. A third of his fables are based on those by Aesop and Lafontaine.

M. N. Zagoskin (1789-1852). Author of comedies and historical novels. He published his novel lurii Miloslavskii. ili Russkie v $1612 \mathrm{~g}$. in 1829 . Another historical novel, Roslavlev, ili Russkie v $1812 \mathrm{~g}$. appeared in 1831.

1841 Н. А. Некрасов, „Сто русских литератов (критика) ... ” Литературная газета, 82-84 (1841).

Второй том Ста литераторов нячинается статьею покойного $\mathrm{A}$. С. Шишкого: „Воспоминание о моем приятеле”. В свое время Шишков играл немаловажную роль в русском литературном мире. Кто не знает, хоть по преданиям, этого грозного, восторженного воителя против вторжения иностранныХ языков в область русского слова? Шишков слишком далеко увлекся своею ненавистью к иностранным словам, но, во всяком случае, влияние его было полезно. Оно сделало столько, сколько именно нужно было сделать для очищения русского языка, которому тогда мешало идти вперед преобладавшая у русских писателей страсть испешрять свои фразы иноземными словами, совершенно без всякой пользы, единственно из какого-то литературного фанфаронства. Шишков часто заблуждался, слишком был пристрастен к своим 
мнениям, но он истинно желал добра русской литературе и ревностно делал все то, что,.по его понятиям, могло принести ей пользу.

A. S. Shishkov died in April 1841 at the age of eighty-seven.

The miscellany Sto russkikh literatorov was a collection of physiological sketches (see below, pp. 265ff.). 


\title{
THE EVOLUTION OF A NATIONAL LITERATURE
}

\author{
Introduction
}

One feature seems to be a permanent characteristic of the Russian literary scene: the continuous polemic between the advocates of an exclusively national Russian literature, often considered by nature superior to West European writing, and the adherents of the contrary view according to which Russian literature has been part of European literature and has followed similar lines of evolution. The national viewpoint has been characterized by the terms "natsional'nost" " and "narodnost' " (coined by Prince Viazemskii), the European view by the term "kosmopolitizm." Karamzin, who had been instrumental in acquainting his countrymen with current West European literature in his journals Moskovskii zhumal, 1781-92, and Vestnik Evropy, (1802-), represented the cosmopolitan view at the turn of the century. This attitude was in consonance with both sentimentalism and early romanticism as represented by Zhukovskii and Batiushkov. Karamzin was opposed by three factions:

(a) Andrei Turgenev's preromantic circle (Druzheskoe literaturnoe obshchestvo, 1801) in Moscow;

(b) The Vol'noe obshchestvo liubitelei slovesnosti, nauk $i$ khudozhestv (founded in 1801) in St. Petersburg;

(c) the neoclassicists who gathered around Admiral Shishkov. Both literary societies in Moscow and St. Petersburg deplored the overwhelming influence of Karamzin's stylistic reforms and expressed themselves in favor of a more national literature which would be devoted to themes of national significance. They frequently referred to the poetry of Lomonosov and Derzhavin as exemplary in this regard.

In the twenties the polemic gained in intensity. Uvarov, minister of education, took advantage of the popularity of the term "narodnost" " and incorporated it into his well-known tripartite formula "pravoslavie, samoderzhavie i narodnost" "(1832). Most romantic authors insisted on the necessity of this quality. The so-called mladoarkhaisty (lu. Tynianov), Katenin, Kiukhel'beker, Zhandr, and Griboedov, who had entered the literary scene after the Napoleonic wars, continued the fight for a more national literature. The Decembrist poets (Ryleev, Bestuzhev and others) were equally engaged on the side of "narodnost" ". In the area of literary criticism, it was especially 
Prince Viazemskii and Somov who stood for the development of a national Russian literary school.

Pushkin's insistence on the necessity of local color and historical perspective (historicism) in literature allied him with the defenders of "narodnost" ". Less regard for the concept was shown by the adherents of "German cosmopolitanism" (Bestuzhev's term), i.e., the representatives of Schelling's romanticism in literature (Venevitinov, Odoevskii, Kireevskii, Koshelev, Rozhalin, Titov) who had gathered in a literary circle in Moscow and were known as liubomudry (1823-1825).

In the 1830's, it was Belinskii who continued to stress the need for "narodnost' " in literature. The publication of Gogol's tales (1831-1836), especially the two collections Mingorod and Arabeski (both 1835), led Belinskii to formulate his views of the new realistic school in literature which later was to be known as the Natural naia shkola. Just as Gogol had emphasized the significance of Pushkin as a national writer, so Belinskii now stressed the importance of Gogol for the same reason. The Lomonosov-Derzhavin tradition was now seen to be continued by Krylov (whose fables had first appeared in 1809), Pushkin, and Gogol. Belinskii linked "narodnost" " to geographical and climatic conditions as well as to national history and folklore. Nadezhdin, on the other hand, strove to unite "cosmopolitan" and "national" features, in a manner analogous to the unity of classicist and romantic trends in realistic literature. In the 1840's, the polemic flared up again in the discussions between Slavophiles and Westernizers. Some writers among the Westernizers, like Belinskii, had their own concept of "narodnost'" which they opposed to the one propagated by the Slavophiles. Other Westernizers, like Maikov, Pleshcheev and the young Dostoevsky, who were under the strong influence of utopian socialist ideas (rejected by Belinskii after 1846), turned altogether against this concept.

Dostoevsky, looking back at his youth and the ideas which then dominated his mind, recalled,

„... все эти идеи об уничтожения нащиональностей во имя всеобщего братства людей, о презрении к отечеству, как тормозу в всеобщем развитии и проч. и проч. - все это были такие влияния, которых мы преодолеть не могли . . ." (Дневник писателя на 1873 год [Paris, YMCA Press, n.d.], p. 359). 
1800 Н. М. Карамзнн, Сочинения (Санкт-Петербург, 183435), IV, стр. 107; IX, crp. 275.

. . Красоты особенные, составляюшие характер словесности народной. уступают красотам общим: первые изменяются, вторые вечны. Хорошо писать для россиян: еще лучше писать для всех людей.

Путь образования или просвещения один для народов; все они идут им вспед друг за другом [ . . Интерес и любовь к русской старине являются] жалкими иеремиадами. Все народное ничто перед человеческим... .

... Главное дело быть людьми, а не славянами. Что хорошо для людей, то не может быть дурно для русских; и что англичане или немцы изобрели для пользы, выгоды человека, то мое, ибо я человек!

Karamzin had undertaken to acquaint the Russian reader with the European literary scene as early as his Moskovskii zhurnal (1791-1792) where he published his Letters of a Russian Traveller. With the foundation of his new journal, characteristically entitled Vestnik Evropy (1802), he continued this task. The above lines supply the rationale for his undertaking and illustrate his cosmopolitan attitude.

1801 А. И. Тургенев, „Речь о русской литературе”

Русский библиобил, 1 (1912).

О русской литературе! Можем ли мы употреблять это слово? Не одно ли это пустое название, тогда когда вещи в самом деле не существуют . . . Читая Ломоносова, Сумарокова, Державина, Хераскова, Карамзина в одном только Державине найдешь очень малые оттенки русского, в прекрасной повести Карамзина Илья Муромеи также увидишь русское название, русские стоны и больше ничего.

По крайней мере теперь нет никакой надежды, чтобы когда-нибудь процвела у нас истинно русская литература. Для сего нужно, чтобы мы и в обычаях, и в образе жизни, и в характере обратились к русской оригинальности, от которй мы удаляемся ежедневно. . . .

Теперь наступает новое столетие, обильнее ли оно будет писателями, нежели прошедшее? Может быть, но, судя по ходу нашей литературе, нельзя ли подумать, что у нас будет больше превосходных писателей в мелочах и что виноват в этом Карамзин.

Andrei Turgenev (1781-1803), the youthful founder of the Druzheskoe literaturnoe obshchestvo (1801), recognized Karamzin's significance for the development of Russian literature, but complained of the consequences-the tearful and effeminate style of late sentimentalism, and the tendency to use small genres (e.g. the preference of lyrical poetry over the more monumental epic forms). 
Есть люди, которые, любя всем сердщем страну своего рождения, обманывают самих себя и, следуя софизмам острого разума, что для истинно просвещенного человека нет отечества, что он не есть патриот, а гражданин вселенной. . . .

This speech, as well as the one above, was delivered before the Druzheskoe literaturnoe obshchestvo (1801). Turgenev referred to Karamzin and his adherents.

1802 Н. М. Карамзин, „О случаях и характерах в росскйской исторнн, которые могут быть шредметом художеств"

Вестник Европы. 24 (1802).

Мне кажется, что я вижу как народная гордость и славолюбие возрастают в России с новыми поколениями! . . . А те холодные люди, которые не верят сильному влиянию изящного на образование душ и смеются (как они говорят) над романическим патриотизмом. достойны ли ответа? Не от них отечество ожидает великого и славного; не они рождены сделать нам имя русское еще любезнее и дороже. . . .

Although Karamazin was attacked for making fashionable the habit of uncritical acceptance of Western influences, he actually attempted to combine patriotism with critical openness towards the West. His literary works of this time show that he was rather critical of the Rousseau' an influence and was developing a growing interest in Russia's past (see his historical novella "Marfa Posadnitsa" [1803]). In general, Karamzin became increasingly conservative in his views after the middle 1790 's.

1819 П. А. Вяземский, [ Пнсъмо А. И. Тургеневу от 22 воября, 1819 г.] Остафьевский архив братьев Тургеневых, I (Санкт. Петербург, 1899).

Зачем не перевести nationalité народность? Поляки сказали же narodowos'c! Поляки не так брезгливы как мы, и слова, которые не добровольно перескакивают к ним, перетаскивают они за волосы, и дело с конщом. Прекрасно! Слово, если нужно оно, укоренится.

Viazemskii's letter shows the author's interest in those qualities for which he coined the neologism "narodnost'." Like Somov, Pletnev, Pushkin and other romantic writers, Viazemskii stressed the importance of a national Russian literature (cf. Somov's state- 
ments on p. $129 f$.

1824 М. А. Дмитриев, [Ответ Вяземскому]

Вестник Европы, 5 (1824).

Народная поззия может существовать и у народа необразованного: доказательство тому наши старинные песни. Поэзия национальная существует единственно у тех народов, которых политическое бытие тесно соединено с просвещением гражданским и одно в другом находит необходимую подпору; у народов, имеющих, при образованности, общей им с другими, свои собственные нравы, свои обычаи, не изглаженные, но только смягченные временем, свои предания, которых, может быть, не признает история, но которым верит дух нации.

The polemic between Viazemskii and M. A. Dmitriev (1796-1866), an adherent of neoclassicist or pseudoclassicist views, began with the publication of Viazemskii's foreword to Pushkin's Bakhchisaraiskii fontan, the "Razgovor mezhdu izdatelem i klassikom..." Dmitriev reacted to Viazemskii's essay with his own "Vtoroi razgovor mezhdu..." (Vestnik Evropy, No. 5, 1824). The polemic was continued on the pages of Vestnik Evropy and the Damskii zhurmal for the greater part of the year.

1824 П. А. Вяземский, [Ответ М. А. Дмитриеву]

Дамский журнал. 5 (1824).

Всякий грамотный знает, что слово национальный не существует в нашем языке; что у нас слово народный отвечает двум французским словам: populaire и national; что мы говорим: песни народные и дух народный там, где французы сказали бы: chanson populaire и ésprit national.

Despite Viazemskii's words, the term "natsional'nost' " bccame firmly established. It was of central importance in a polemic between Belinskii and V. Maikov two decades later.

1824 В. К. Кюхельбекер, „О направленин нашей поэзин особенно лирнческой, в последнее десятилетие"

Мнемозина, II (1824).

Но не довольно, - повторяю, - присвоить себе сокровища иноплеменников: да создастся для славы России поэзия истинно русская; да 
будет святая Русь не только в гражданском, но и в нравственном мире первою державою во вселенной! Вера праотцев, нравы отечественные, летописи, песни и сказания народные - лучшие, чистейшие, вернейшие источники для нашей словесности.

V. K. Kiukhel'beker (1797-1846), like Katenin in his ballad "Ol'ga," wanted a national Russian literature that would be independent of foreign models. His article was an important statement of his convictions. The journal Mnemozina (1824-1825), the organ of the liubomudry group (adherents of Schellingian romanticism), was published by Kiukhel'beker in collaboration with V. F. Odoevskii.

1825 А. С. Пушкин, [ 0 народности в лнтературе ]

Собрание сочинений. VI (Москва, 1962).

С некоторых пор вошло у нас в обыкновение говорить о народности, требовать народности, жаловаться на отсутствие народности в произведениях литературы, но никто не думал определить, что разумеет он под словом народность.

Один из наших критиков, кажется, полагает, что народность состоит в выборе предметов из отечественной истории, другие видят народность в словах, третьи радуются тем, что изъясняясь по-русски, употребляют русские выражения. . . .

Народность в писателе есть достоинство, которое вполне может быть оценено соотечественниками - для других оно или не существует, или даже может показаться пороком. . . .

Климат, образ правления, вера дают каждому народу особенную физиономию, которая более или менее отражается в зеркале поэзия. Есть образ мыслей и чувствований, есть тьма обычаев, поверий и привычек, принадлежащих исключительно какому-нибудь народу.

Pushkin's definition established the significance of the concept of narodnost' for the growing awareness of both writers and critics of the need for historical perspective in the literary history of a nation. Istorizm, understood as a criterion demanding that all cultural phenomena be seen in relation to their time, became an important characteristic for romantic and realistic literature.

---, [ [Соременная бнблнография ]

Москивский телеграф, II (1829).

Полтава, поэма Александра Пушкина, СПб. 1829.

С появлением в свет сей поэмы, Пушкин становится на степень столь высокую, что мы не смеем в кратком известия изрекать приговора новому его произведенню . . . 
. . . Мы . . . видим в ней, при всех других достоинствах, новое: народность. В Полтаве, с начала до конца, везде русская душа, русский ум, чего, кажется, не было в такой полноте ни в одной из поэм Пушкина.

Pushkin had stressed his desire to remain in the confines of historical truth in his foreword to the poem. His work was received coolly by other critics. Severnaia pchela (No. 35,1830 ) even said: "...kholodnyi priem, okazannoi poeme Poltava, sluzhit iasnym dokazatel'stvom, chto ocharovanie imen ischezlo..."

1831 А. А. Бестужев, [ Письмо Н. Полевому от 23 апреля 1831 года ] Русский вестник, XXXII (март, 1861).

. . . Я был горячим ненавистником немецкого космополитизма, убиваюшего всякое благородное чувство отечественности, народности. . . .

Bestuzhev speaks of German idealistic philosophy.

1833 П. А. Плетнев, „О народности в литературе“" Журнал Министерства Народного Просвещения, I, 2 (1834), стр. 1-30.

В числе главных принадлежностей, которых современники наши требуют от произведений словесности, господствует идея народности. Она предстваляет собою особенность, необходимо соединяющуюся с идеею каждого народа. Сколько ж предметов должно войти в ее совокупность!

. . . Один и тот же народ, в разные периоды своей истории, при содействии разных причин, скрываюшихся то в политике, то в морали, то в ученых мнениях какого-нибудь времени, является с бесчисленным множеством оттенков, которые все принадлежат рассматриваемой идее.

P. A. Pletnev (1792-1865) was a well-known literary critic and a minor poet of the 1820 's and 1830 's. In 1832 he became a university professor of Russian literature in $\mathrm{St}$. Petersburg. It was he who taught this subject to the heir-apparent. He was a personal friend of Pushkin, Zhukovskii, Gogol and other romantic writers. His critical essays reflect romantic views. In an early essay on Gnedich's poem "Rybaki" (1822) he differentiated between "vseobshchaia" or "neopredelennaia" and "narodnaia poeziia." He gave a speech on this subject in 1833 (above) and further developed his understanding of the national specifics of literature in his essays of the late 1830 's. 
Он [Пушкин] при самом начале своем уже был национален, потому что истинная нащиональность состоит не в описании сарафана, но в самом духе народа. Позт даже может быть и тогда нацнонален, когда отисывает совершенно сторонний мир, но глядит на него глазами своей национальной стихян, глазами всего народа, когда чувствует и говорит так, что соотечественникам его кажется, будто это чувствуют и говорят они сами. . . .

Gogol was at that time a close collaborator of Pushkin for whose journal Sovremennik (begun 1836) he wrote a programmatic review, "O dvizhenii zhumal'noi literatury $v$ 1834 i 1835 godu" (vol. l, pp. 192-225). Pushkin later indicated that Gogol's views were not identical with his own (see his "Pis'mo $k$ izdateliu," signed A. B. in vol. III [1836]). Gogol wrote the above essay between 1832 and 1834 . He was one of the first to recognize Pushkin's role as a national writer. Gogol's definition of "istinnaia narodnost'" seems intended as an answer to the official concept of "narodnost'."

\section{3-34 А. И. Герцен, [ Литература и обшество ]}

Полное собрание сочинений, I (Леннтрад, 1954).

. . . Пора убедиться, что истина, где бы ни была открыта, делается достоянием всего человечества. Касательно литературы собственно дело другое, она должна быть национальна, должна истекать из всей жизни народной и представлять ее без всяких посторонних элементов. В науках же надобно очень благодарить те, которые знакомят нас с Европой. ...

A. I. Gertsen (1812-1870) was a student in his early twenties when he wrote the above lines, which are evidence of his interest in the achievements of European scholarship. During his years at the university $(1829-1833)$ he published several translations and original essays on scientific topics.

1834 В. Г. Белинский, „Литературные мечтания"

Молва, 38-52 (1834).

Каждый народ вследствие непреложного закона провидения должен выражать своею жизнию одну какую-нибудь сторону жизни целого человечества; в противном случае этот народ не живет, а только прозябает, и его существование ни к чему не служит. . . . 
В чем же состоит эта самобытность каждого народа? В особенном, одному ему принадлежащем образе мыслей и взгляде на предметы, в религии, языке и более всего в обычаях. Все эти обстоятельства чрезвычайно важны, тесно соединены между собою и условливают друг друга, и все проистекают из одного общего источндка - причины всех причнн - климата и местности. Между сими отличнями каждого народа обычаи играют едва ли не самую важную роль, составляют едва ли не самую характеристическую черту оных. . . .

Романтизм - вот первое слово, огласившее пушкинский период; народность - вот альфа и омега нового периода. Как тогда всякий бумагомаратель из кожи лез, чтобы прослыть романтиком, так теперь всякий литературный шут претендует на титло народного писателя. Народность - чудное словечко! . . .

Начало этого народного направления в литературе было сделано еще в пушкинском периоде; только тогда оно не так резко выказалось. Зачиншиком был г. Булгарин. Но так как он не художник, в чем теперь никто уже не сомневается, кроме друзей его, то он принес своими романами пользу не литературе, а обществу, то есть каждым из них доказал какую-нибудь практическую житейскую истину. . . .

И в самом деле, какое понятие имеют у нас вообще о народности? Все, решительно все смешивают ее с простонародностию и отчасти с тривиальностию. Но это заблуждение имеет свою причину, свое основание, и на него отнюдь не должно нападать с ожесточением. Скажу более: в отношении к русской литературе нельзя иначе понимать народности. Что такое народность в литературе? Отпечаток народной физиономии, тип народной жизни; но имеем ли мы свою народную физиономию? Вот вопрос трудный для решения. Наша нашиональная физиономия всего больше сохранилась в низших слоях народа; посему наши писатели, разумеется владеющие талантом, бывают народны, когда изображают, в романе или драме, нравы, обычаи, понятия и чувствования черни.

The essay "Literaturnye mechtaniia" was the first major article by Belinskii (then 23 years old!) and made him well-known. In the above excerpt, Belinskii seems to refer to Bulgarin's novel Ivan Vyzhigin, nravstvenno-satiricheskii roman which was praised highly in Moskovskii telegraf and Moskovskii vestnik, and to the same author's historical novel Dmitrii Samozvanets (1830) in which Bulgarin had used material from Pushkin's Boris Godunov (see below, p. 251.).

Belinskii here echoes Herder's view that every major nation is destined to make its own specific contribution to the cultural evolution of mankind, depending on its national character and the influences of climate and the geographical setting (see his Ideen zur Philosophie der Geschichte der Menschheit, 1884-91, Book 7, 15). 
Г. Марлинский начал свое поприще с повестей русских, народных, т.е. таких, содержание которых берется из мира русской жизни. Как опьт, как попытка они были прекрасны и в свое время заслужили справедливое внимание; но как произведения не созданные, а сделанные они теперь утратили свою цену. В них не было истины действнтельности, следовательно, не было и истины русской жизни. Народность их состояла в русских именах, в избежании явного нарушения верности событий и обычаев и в подделке под лад русской речи - в поговорках и пословицах, но не более. Русские персонажи повестей г. Марлинского говорят и действуют, как немецкие рыцари; их язык риторический. вроде монологов классической трагедии, и посмотрите с этой стороны на „Бориса Годунова” Пушкина - то ли это?

Between 1823 and 1825 Bestuzhev-Marlinskii (1797-1837) wrote several novellas set in the Baltic provinces of Russia. Belinskii refers here to Bestuzhev-Marlinskii's novellas Roman i Ol'ga (1823), Izmennik (1825), Listok iz Dnevnika gvardeiskogo ofitsera (1823). In the early 1830 's he again published novellas, this time depicting the social life of the time, events from the Napoleonic wars, and life in the Caucasus.

1835 В. Г. Белинскнй, „0 русской повести н повестях г. Гоголя" Teлlecкоп, 7.8 (1835).

. . . Эта способность понимать явления жизни очень не чужда г. Полевому. Сколько истины в его „Живописце" и „Эмме”! . . .

Tenерь в „Святочных рассказах" и „Рассказах русского солдата" сколько того, что называется народностию, из чего так хлопочут наши авторы. что им менее всего удается и что всего легче для истинного таланта! Это мир совершенно отдельный, мир, полный страстей, горя и радостей, все человеческих же, но только выражающихся в других формах, по своему. Тут нет ни одной побранки, ни одного плоского слова, ни одной вульгарной картины, и между тем так много поэзии и, мне кажется, именно потому, что автор старался быть верным больше истине, чем народности, искал больше человеческого, нежели русского, и вследствие этого народное и русское само пришло к нему. ... .

Отличительный характер повестей r. Гоголя составляют - 
простота вымысла, народность, совершенная истина жизни, оригинальность и комическое одушевление, всегда побеждаемое глубоким чувством грусти и уныния. Причина всех этих качеств заключается в одном источнике: r. Гоголь - это поэт, поэт жизни действительной. . . .

В самом деле, заставить нас принять живейшее участие в ссоре Ивана Ивановича с Иваном Никифоровичем, насмешпть нас до слез глупостями, ничтожностию и юродством этих живых пасквилей на человечество - это удивительно; но заставить нас потом пожалеть об этих идиотах, пожалеть от всей души, заставить нас расстаться с ними с каким-то глубоко грустным чувством, заставить нас воскликнуть вместе с собою: „Скучно на этом свете, господа!” - вот, вот оно, то божественное искусство, которое называется творчеством; вот он, тот художнический талант, для которого где жизнь, там и поззия! И возьмите почти все повести г. Гоголя: какой отличительный характер их? Что такое почти каждая из его повестей? Смешная комедия, которое начинается глупостями, продолжается глупостями и оканчивается слезами и которая, наконещ, называется жизнию. И таковы все его повести: сначала смешно, потом грустно! И такова жизнь наша: сначала смешно, потом грустно! Сколько тут поззии, сколько философии, сколько истины! . . .

Совершенная истина жизни в повестях г. Гоголя тесно соециняется с простотою вымысла. Он не льстит жизни, но и не клевещет на нее; он рад выставить наружу все, что есть в ней прекрасного, человеческого. и в то же время не скрывает нимало и ее безобразия. В том и другом случае он верен жизни до последней степени. Она у него настоящий портрет, в котором все схвачено с удивительным сходством, начиная от экспрессия оригинала до веснушек лица его; начиная от гардероба Ивана Никифоровича до русских мужиков, идуших по Невскому проспекту, в сапогах, запачканных известью; от колоссальной физнономи богатыря Бульбы, который не боялся ничего в свете, с люлькою в зубах и саблею в руках, до стоического философа Хомы, который не боялся ничего в свете, даже чертей и ведьм, когда у него люлька в зубах и рюмка в руках.

Повести г. Гоголя народны в высочайшей степени: но яне хочу слишком распространяться о их народности, ибо народность есть не достоинство, а необходимое условие истинно художественного произведения, если под народностию должно разуметь верность изображения нравов, обыгаев и характера того или другого народа, той или другой страны.

Nikolai Polevoi (1796-1846), a self-taught writer, son of a merchant, began his literary career in the early 1820's in Moscow. After becoming acquainted with V. F. Odoevskii and the Russian Schellingists ("wisdom-lovers" or "liubomudry") he interested himself in romantic philosophy and began to publish in Mnemozina. Between 1825 and 1834 he edited the romantic journal Moskovskii telegraf, a forerunner of the "thick" 
journals of a later age. Polevoi published a four-volume Istoriia russkogo naroda (18291833) and several romantic novelbas, such as Emma (1829), Zhivopisets (1833), Bla. zhenstvo bezumiia (1833), Abbadonna (1834) and others. A two-volume edition of his works appeared under the characteristic title Mechty i zhizn' (1834). His Rasskazy russ. kogo soldata (1829) were written in a more realistic style using dialect expressions. Gogol published two collections of stories in 1835, Arabeski and Mirgorod. Belinskii gave his evaluation of them in the above lines, which also illustrate his understanding of realism. Annenkov reported that Gogol was flattered by Belinskii's review. Conservative critics (Voeikov, Bulgarin, and others) disputed Belinskii's views.

В. Г. Белинский, „О народности"

Телескоп, XXXI, 3 (1836).

. . Итак, если личность поэта должна отражаться в его творениях, то может ли не отражаться в них его народносгь? Разве всякий поэт, прежде чем он человек, не есть русский, француз или немец? - Возьмем поэта русского: он родился в стране, где небо серо, снега глубоки, морозы трескучи, вьюги страшны, лето знойно, земля обильна и плодородна: разве все это не должно положить на него особенного характеристического клейма? Он в младенчестве слышал сказки о могучнх богатырях, о храбрых витязях, о прекрасных царевнах и княжнах, о злых колдунах, о страшных домовых; он с малолетства приучил свой слух к жалобному, протяжному пению родных песен; он читал историю никакой другой страны в мире. . . . Если он поэт, поэт истинный, то не должен ли сочувствовать своему отечеству, разделять его надежды, болеть его болезнями, радоваться его радостями?

1836 Н. И. Надеждин, „Европеизм и народность в отношенян к русской словесности"

Tелескоп, XXXI (1836).

Итак ни исключительная народность, не исключительное чужеядство не достаточны для полной литературной жизни. И то, и другое, действуя отдельно, в самом себе носит семена разрушения. Так все первобытные литературы древних народов Востока погибли, закостенев в своей неподвижной, затворнической народности; и что, например, вся нынешняя китайская словесность, этот любопытный образчик национального духа, сомкнувшегося в самом себе, как не мертвая, холодная мумия? С другой стороны, такова же была судьба ученой латинской литературы средних веков, где могущество духа человеческого истощалось в тяжких усилияХ воссоздать из развалин погибшую древность, воскресить ее дух, оживить формы - этой замечательной эпохи в летописях человечества, когда вся творческая деятельность ограничивалась искусством 
снимать с чуждых образцев точные копии! - Что же должно заключить отсюда? - Что развитие литературной жизни, полное и успешное, не иначе возможно, как при гармоническом слиянии обоих противоположных направлений творящего духа, - что литература жнвая должна быть плодом народности, питаемой, но не подавляемой общительностью!

. . . Литература есть глас народа; она не может быть привилегиею одного класса, одной касты; она есть общий капитал, в котором всякий участвует, всякий должен участвовать. Если может быть какоенибудь общение, какой-нибудь дружный, братский союз между разными сословиями, разными классами народа, так это в литературе и через литературу. Основание народного единства есть язык; стало, он должен быть всем понятен, всем доступен! . . . Во вторых, положим, что нсправление вкуса должно начинаться облагородствованнем форм, что это облагородствование всего скорее должно обнаружнваться в гостиных, на этой верхушке общественной пирамиды, которая раньше должна озаряться лучами восходящей шивилизащии; положнм, что литература должна чуждаться шума улиц и звучать по камертону бельэтажей; спрашивается: возможно ли это у нас, при настоящем состоянии русского языка в бельэтажах? Говорят ли там, умеют ли говорить по-русски?...

. . . Многие под народностью разумеют одни наружные формы русского быта, сохраняющиеся теперь только в простонародии, в низшнх классах обшества. И вот тьма тьмущая наших писателей, особенно писачек из задних рядов, ударились со всего размаха лицом в грязь этой грубой, запачканной, безобразной народности, которую всего лучше следовало бы называть простонародностью. Они погрузиіись во шти, в квас, в брагу, забились на полати, обливаются ерофеичем, закусывают луком, передразнивают мужиков, сидельщев, подьячих, ямщиков, харчевников; и добро бы, подобно знаменитому А. А. Орлову! главе этой школы народных писателей, ограничивались современными картинами низших слоев общества, что имело бы по крайней мере достоинство верности; нет! они теребят русскую историю, малюют ее лучшие эпохи своей мазилкой, одевают в нынешний зипун дела давно минувших дней. преданья старины глубокой'2 . . О такой народности что и говорить? Ее надо так же гнать из литературы, как критики одного из наших журналов гнали некогда историю из романа! ${ }^{3}-$ Впрочем и здесь должно сделать важное исключение. Всякий простой быт имеет свою поэзию; русский также! - Положим, что А. А. Орлов слишком уже глубоко погружается в эту поэзию, что он вытаскивает ее и предает печати сыромятную, невыделанную, во всей наготе, которая не может быть не отвратительна; но всему есть мера! . . . Отчего ж, например, у Загоскина русский мужик не только не противен, но положительно хорош, интересен, поэтичен (если можно так выразиться)? Отчего 
у Гоголя казак мертвецки пьяный, по уши в грязи, с подбитыми глазами, отчего Иван Никифорович даже в натуре ознаменован какою-то неизъяснимою, очаровательною прелестью, которая заставляет прощать или по крайне мере пропускать меж пальцев его противуобщественное положение? - Я говорю это, чтобы доказать, что народность и в этом ограниченном, грязном смысле, пройдя через горнило вдохновения, может иметь доступ в литературу и, следовательно, не заслуживает безусловного преследования, отвержения! - Но народность, которой я требую, имеет гораздо обширнейшее значение. Под народностью я разумею совокупность всех свойств, наружных и внутренних, физических и духовных, умственных и нравственных, из которых слагается физиономия русского человека, отличающая его от всех прочих людей европейцев столько ж, как и азиятцев. Как ни резки оттенки, положенные на нас столь различными влиякиями , столь разных цивилизащий, русский человек во всех сословиях, на всех ступенях просвещения и гражданственности имеет свой отличительный характер, если только не прикицывается умышленно обезьяною. Русский ум имеет свой особый сгиб; русская воля отличается особенной, ей только свойственной упругостью и гибкостью; точно так же, как русское лицо имеет свой особый склад, отличается особенным, ему только свойственным выражением. У нас стремление к европеизму подавляет всякое уважение, всякое даже внимание к тому, что именно русское, народное. Я совсем не вандал, который бы желал отшатнуться опять в век, задвинутый от нас Петром Великим (по счастливому выражению одного уважаемого литератора). Но позволю себе сделать замечание, что в Европе, которую мы принимаем за образец, которую так усердно копируем всеми нашими действиями - народность, как я ее понимаю, положена во главу угла щивилизащии,столь быстро, столь широко, столь свободно распространяющейся. . . .

Заключаю мое длинное рассуждение следующим резудьтатом. .Литература у нас есть; есть и литературная жизнь; но ее развитие стесняется односторонностью подражательного направления, убивающего народность, без которой не может быть одной литературной жизни!" Вот мой тезис, который вызываю опровергнуть!

. . . В основание нашему просвещению положены православие, самодержавие и народность. Эти три понятия можно сократить в одно, относительно литературы. Будь только наша словесность народною: она будет православна и самодержавна!

1. A. A. Orlov (1791-1840), minor author of popular stories, published three novels in 1831 which continued the plot of Bulgarin's Iuan Vyzhigin (1829) and appeared simultaneously with Bugarin's own continuation of his novel, Petr Ivanovich Vyzhigin (1830).

2. A line quoted from Pushkin's poem Ruslan i Liudmila.

3. Nadezhdin refers to Moskovskii vestnik, in particular, to Shevyrev and Titov. 
As editor of Teleskop (1831-1836) and its supplement Molva, Nadezhdin opposed the attitude of Shevyrev and his journal Moskovskii nabliudatel' (1835-1839) who represented the slavophile orientation in matters of "narodnost" ". Belinskii collaborated in Teleskop beginning in 1833. In his programmatic essay above, Nadezhdin demanded the realization of an original, national Russian literature. "Narodnost" " was identified with the individuality of the Russian nation. Nadezhdin's definition approached the official concept of the term.

1841 Н. П. Отарев, [ Пнсымо от 1841 г. М. Л. Отаревой ] Избранные сочиально-политические и философские произведения, II (Москва, 1956), crp. 327.

Наша народность довольно оригинальна и содержит довольно глубокий поэтический элемент, чтобы трудиться представить ее в поэтических образах. И именно надо спуститься в низший слой общества. Тут-то истинная народность, всегда трагическая. Высший и средний слой, довольно уродливо проникнутый европейской жизњю, имеет больше комического элемента.

N. P. Ogarev (1813-1877), a distant relative and close friend of Herzen, and a philosophically inclined poet, began to publish translations of philosophical essays during his years as a student (1831-1832). Together with Herzen he played an important part in radical Westem-oriented student circles. His first poems appeared in Otechestvennye zapiski and Literatumaia gazeta in the 1840's and reflected his romantic and philosophical lyricism.

1844 В. Г. Белинскй, „Сочннення Александра Пушкина” (статья V) Отечественные записки, XXXII, 2(1844).

Толпа, в смысле массы народной, есть прямая хранительница народного духа, непосредственный источник таинственной психеи народной жизни. Народ (взятый как масса), духовная субстанция жизни которого не В состоянии порождать из себя великих поэтов, не стоит названия народа или нации - с него довольно чести называться просто племенем. Поэт, которого поэзия выросла не из почвы субстанщиальной жизни своего народа, не может ни быть, ни называться народным или национальным поэтом. . .

Народный поэт - тот, которого весь народ знает, как, например, знает Франция своего Беранже; начиональный поэт - тот, которого знают все сколько-нибудь образованные классы, как, например, немцы знают Гете и Шиллера. Наш народ не знает ни одного своего поэта; он 
поет себе доселе „Не белы-то снежки”, не подозревая даже того, что поет стихи, а не прозу . . . Следовательно, с этой стороны, смешно бьло бы и говорить об эпитете „народный” в применения к Пушкину или $к$ какому бы то ни было поэту русскому. Слово „нацональный” еще обширнее в своем значении, чем „народный”. Под „народом” всегда разумеют массу народонаселения, самый низший и основный слой государства. Под „нашиею” разумеют весь народ, все сословия, от низшего до высшего, составляюшие государственное тело. Нащиональный поэт выражает в своих творениях и основную, безразличную, неуловимую для определения субстанциальную стихию, которой представителем бывает масса народа, и определенное значение этой субстанциальной стихии, развившейся в жизни образованнейших сословкй нацин. Национальный поэт - великое дело! Обращаясь к Пушкину, мы скажем, по поводу вопроса о его нащиональности, что он не мог не отразить в себе географически и физиологически народной жизни, ибо был не только русский но притом русский, наделенный от природы гениальными силами; однако ж в том, что называют народностью или национальностью его поэзии, мы больше видим его необыкновенно великий художнический такт.

Belinskii outlines a view of "natsional'nost" " which a few years later was violently attacked by Maikov and other radical Westernizers (see below, p. 58 f.).

1845 И. В. Кнреевский, [ Библиографнческне статьн]

Полное собрание сочинений. II (1911).

Величие таланта Крылова заключается не столько в великом литературном достоинстве его произведений, сколько в красоте их народности. Крылову принадлежит честь единственная, ни с кем не разделенная: он умел быть народным, и что еще важнее, он хотел быть русским в то время, когда всякое подражание почиталось просвещением, когда слово: иностранное, было однозначительно с словом умное или прекрасное; когда поклоняясь нашим выписным гувернерам, мы не знали оскорбительного слова, хуже слова: moujik! В это время Крылов не только был русским в своих баснях, но умел еще сделать свое Русское пленительным даже для нас. Хотя долго продолжалось время, когда и ему не отдавали справедливости, с исключительным восторгом читали басни Дмитриева, впрочем исполненные истинных красот, и почти против совести смеялись русским рассказам Крьлова.

Крылов бьл прекрасен своей народностию, но не в силах распространить ее влияние на словесность. Это предоставлено было другому. 
Что Крылов выразил в свое время и в своей басенной сфере, то в наше время и в сфере более обширной выражает Гоголь. . . .

После появления Мертвых душ Гоголя, много говорено было за них и против них не только в литературе, но и во всех кругах читателей; между тем, от восторженньх похвал и страстных порицаний осталось, кажется, одно общее убеждение, что Гоголь в словесности нашей есть представитель той новой, великой, до сих пор в ясном виде еще не являвшейся силы, которой неисчислимые результаты могут произвести совершенный переворот в нашей литературе, и которую называют силок. русской народности. До сих пор мы были и находимся еще под влиянием Французов и немцев. Жизнь нашей словесности оторвана от жизни нашего народа. Но, читая Гоголя, мы понимаем возможность их соеди. нения. Впрочем, не потому Гоголь народен, что содержание рассказов егл взято по большей части из русской жизни: содержание не характер; Шекспир столько же англичанин, описывая Рим и Венешию, сколько в своих британских драмах; не потому также называем мы Гоголя народным, чтобы народ читал его (слава Богу, народ наш еше живет в литературе славянской, и немногие, просвешенные грахданскою грамотностию, продолжают образовываться посрелством Выжигина. Орлова и Поль де Кока) ; но потому, что в глубине души его таятся особенные звуки, потому что в слове его блестят особенные краски, в его воображении живут особенные образы, исключительно свойственные русскому народу, тому свежему, глубокому народу, который не утратил еще своей личности в подражаниях иностранному.

The first volume of Krylov's fables appeared in 1809 and was received enthusiastically (see p. 225n).

Gogol's novel Mernye dushi was published in 1842.

1. V. Kireevskii (1806-1856), journalist and critic, was one of the central figures of the slavophile movement.

Concerning the novel $V_{y}$ zhigin and Orlov, see p. 52.

Charles-Paul de Kock (1793-1871), author of many society novels, popular in the 1820's and 1830's in Europe.

1845 И. В. Кнреевскнй, „Обозренне современного состояния литературы” Москвитянин, 1-2 (1845).

Отдельные западные народности. достигнув полноты своего развития, стремятся уничтожить разделяющие их особенности и сомкнут в одну. обще-европейскую образованность.

Этот результат тем замечательнее, что он развился из направления ему прямо противуположного. Преимущественно произошел он из стремлений каждого народа изучить, восстановить и сохранить свою национальную особенность. Но эти стремления чем глубже развивались в исторических, философских и общественных выводах, чем более доходили до коренных основ отделенных народностей, тем яснее 
встретили в них начала не особенные, но общие Европейские, равно принадлежашие всем частным национальностям. Ибо в общей основе Европейской жизни лежит одно господствующее начало. . . .

Произведения нашей словесности, как отражения Европейских, не могут иметь интереса для других народов, кроме интереса статистического, как показания меры наших ученических успехов в изучении их образщов. Для нас самих они любопытны как пополнение, как объяснение, как усвоение чужих явлений; но и для нас самих, при всеобщем распространении знания иностранных языков, наши подражания остаются всегда несколько ниже и слабее своих подлинников. . . .

Направление к народности истинно у нас, как высшая ступень образованности, а не как душный провиншиализм. Потому, руководствуясь этой мыслью, можно смотреть на просвещение Европейское, как на полное, одностороннее, не проникнутое истинным смыслом, и потому ложное; но отрищать его как бы не существующее, значит стеснять собственное. Если Европейское, в самом деле, ложное, если действительно противоречит началу истинной образованности, то начало это, как истинное, должно не оставлять этого противоречия в уме человека, а напротив, принять его в себя, оценить, поставить в свои границы и, подчинив таким образом собственному превосходству, сообщить ему Свой истинный смысл.

In 1845, Ivan Kireevskii took over the editorship of the slavophile journal Moskvitianin (1841-1856), formerly edited by Pogodin, and published the above programmatic essay in it. Kireevskii's view of Europe expresses the slavophile concept of a civilization which is dominated by one universal principle - that of rational philosophy. To this he opposes Russian civilization which he says is founded on the purity of the Christian faith as contained in orthodoxy.

1846 В. Г. Белинский, „Русская литература в 1845 году” Отечественные записки, 1 (1846).

Если бы нас спросили, в чем состоит существенная заслуга новой литературной школы, - мы отвечави бы: в том именно, за что нападает на нее близорукая посредственность или низкая зависть, - В том, что от высших идеалов человеческой природы и жизни она обратилась к так называемой „толпе”, исключительно избрала ее своим героем, изучает ее с глубоким вниманием и знакомит ее с нею же самою. Это значнло повершить окончательно стремление нашей литературы, желавшей сделаться вполне национальною, русскою, оригинальною и самобытною; это значило сделать ее выражением и зеркалом русского общества, одушевить ее живым национальным интересом. Уничтожение всего 
фальшивого, ложного, неестественного долженствовало быть необходимым результатом этого нового направления нашей литературы, которое вполне обнаружилось с 1836 года, когда публика наша прочла „Миргород” и „Ревизора". С тех пор, весь ход нашей литературы, вся сущность ее развития, весь интерес ее истории заключался в успехах новой школы.

Belinskii refers to the "natural'naia shkola," the new literary trend which was linked to Gogol's tales and his novel Dead Souls.

1846 В. Г. Белинския̆, „О жнзнн и сочннениях Колыова” При изданни: Стихотворения Кольцова (Санкт-Петербург, 1846) .

. . . Кольцов родился для поэзии, которую он создал. Он был сыном народа в полном значении этого слова. Быт, среди которого он воспитался и вырос, был тот же крестьянский быт, хотя несколько и выше его. Кольцов вырос среди степей и мужиков. Он не для фразы, не для красного словца, не воображением, не мечтою, а душою, сердцем, кровью любил русскую природу и все хорошее и прекрасное, что как зародыш, как возможность, живет в натуре русского селянина. Не на словах, а на деле сочувствовал он простому народу в его горестях, радостях и наслаждениях. Он знал его быт, его нужды, горе и радость. прозу и поззию его жизни. - знал их не понаслышке, не из книг, не через изучение, а потому, что сам, и по своей натуре и своему положению, был вполне русский человек. Он носил в себе все элементы русского духа, в особенности страшную ситу в страдании и в наслаждении, способность бешено предаваться и печали и веселию и вместо того, чтобы падать под бременем самого отчаяния, способность находить в нем какое-то буйное. удалое, размашистое упоение, а если уже пасть, то спокойно, с полным сознанием своего падения, не прибегая к ложным утешениям, не ища спасения в том, что не нужно было ему в его лучшие дни.

... Нельзя было теснее слить своей жизни с жизнию народа, как это само собою сделалось у Кольцова.

... Кольцов знал и любил крестьянский быт так, как он есть на самом деле, не украшая и не поэтизируя его. Поззию этого быта нашел он в самом быте, а не в риторике, не в пиитике, не в мечте, даже не в фантазии своей, которая давала ему только образы для выражения уже данного ему действительностию содержания. И потому в его песни смело вошли и лапти, и рванные кафтаны, и всклокоченные бороды, и старые онучи - и вся эта грязь превратилась у него в чистое золото поэзии. Любовь играет в его песнях большую, но далеко не исключительную роль; нет, в них вошли и другие, может быть еще более общие 
элементы, из которых слагается русский простонародный быт. Мотив многих его песен составляет то нужда и бедность, то борьба из копейки, то прожитое счастье, то жалобы на судбу-мачеху.

In his introduction to the collected poems of Kol'tsov, Belinskii deduced the greatness of the poet from the fact that he had come from the people (a merchant family) and identified with them in his songs and poems. Belinskii's view was a logical extension of his earlier statements on "narodnost" ". The young critic V. N. Maikov opposed Belinskii (see below).

1846 В. Н. Майков, „Стихотворення Кольцова . . . СПб. 1846” Отечественные записки, 11-12 (1846).

. . В Кольцове не было ничего странного, но было много такого, что выходит из уровня обыкновенности, приближаясь к чистоте человеческого тила. Это явление необходимо наводит на многие вопросы об особенностях великих натур и открывает множество коренных заблуждений. Одно из них обращает на себя особенное внимание при исследовании личности Кольцова. Оно касается национальности. Слушая и читая суждения об этом замечательном человеке, мы не могли не заметить, что все панегиристы называют его типом русской натуры. С своей стороны, мы убеждены, что человек, которого можно назвать типом какой бы то ни было нации, - никак не может быть не только великим, но даже необыкновенным.

... Кахдый народ имеет две физиономии; одна из них диаметрально противоположна другой; одна принадлехит большинству. другая меньшинству (миноритету). Большинство народа всегда представляет собою механическую подчиненность влияниям климата, местности, племени и судьбы. Меньшинство же впадает в крайность отрицания этих влияний. . . Ч Человечность находится в прямой противоположности с нащиональностью. .. назвать Кольцова представителем русской натуры значит назвать его представителем тех отступлений от человеческого типа, которые не редко встречаются. . .

Другое дело национальность в смысле верности в изображении народных особенностей. Если вы назовете национальным того художника, который умеет смотреть на веши глазами изображаемого им народа, умеет отличать национальное от человеческого и не смешивает оригинальности одной нации с оригинальностью другой, вы будете правы, тысячу раз правы. 
Valerian Maikov (1823-1847), brother of the poet Apollon Maikov, began his caree in 1845 when he became unofficial editor of the journal Finnskii vestnik. He was close to the utopian-socialist Petrashevskï group and participated in editing the Karmannyi slovar' inostrannykh slov (1845) which spread socialist views in the guise of a dictionary. In 1846-47 he published several critical essays in Otechestvennye zopiski. He was one of the first to define the role of psychological analysis in Dostoevsky's early work. His views concerning Kol'tsov and the nature and role of "natsional'nost' " were diametrically opposed to those of Belinskii.

1846 В. Г. Белинский, „Взгляд на русскую литературу 1846 года” Современник, 1 (1847).

В особенности вопрос о „народности” сделался всеобшим вопросом и проявился в двух крайностях. Одни смешали с народностью старинные обычаи, сохранившиеся теперь только в простонародье, и не любят, чтобы при них говорили с неуважением о дурной и грязной избе, о редьке и квасе, даже о сивухе: другие, сознавая потребность высшего национального начала и не находя его в действительности, хлопочут выдумать свое и неясно, намеками указывают нам на смирение, как на выражение русской нащиональьности.

... Естественно, что подобные крайности вызывают такие же противоположные им крайности. Одни бросились в фантастическую народность, ${ }^{1}$ другие в фантастический космополити зм во имя человечества. ${ }^{2}$ По мнению последних, национальность происходит от чисто внешних влияний и выражает собою все, что есть в народе неподвижного, грубого, ограниченного, неразумного, и диаметрально противсполагается всему человеческому. Чувствуя же, что нельзя отринать в народе и человеческого, противоположного, по их мнению, национальному, они разделяют неделимую личность народа на большинство и меньшинство, приписывая последнему качества, диаметрально противоположные качествам первого. Таким образом, беспрестанно нападая на какой-то дуализм, который они видят всюду, даже там, где его вовсе нет, они сами впадают в крайность самого отвлеченного дуализма. Великие люди, по их понятию, стоят вне своей национальности, и вся заслуга, все величие их в том и заключается, что они идут прямо против своей национальности, борются с нею и побеждают ее. Вот истинно русское и в этом отношении резко нащиональное мнение, которое не могло бы прийти в голову европейцу! Это мнение вытекло прямо из ложного взгляда на реформу Петра Великого, который, по общему в России мнению, будто бы уничтожил русскую народность, Это мнение тех, которые народность видят в обычаях и предрассудках, не понимая. что в них действительно отражается народность, но что они одни отнюдь еще не составляют народности. Разделить народное и человеческое на два совершенно чуждые, даже враждебные одно другому начала - 
значит впасть в самый абстрактный, в самый книжный дуализм.

.. . Собственно говоря, борьба человеческого с национальным есть не больше, как реторическая фигура, но в действительности ее нет. Даже и тогда, когда прогресс одного народа совершается через заимствование у другого, он тем не менее совершается нащионально.

1. Slavophiles.

2. V. N. Maikov, A. N. Pleshcheev, F. M. Dostoevsky.

The above essay is one of the most essential literary statements of the late Belinskii (he died in June 1848). It was published in Sovremennik which had just been taken over by Nekrasov and Panaev. Belinskii was its guiding spirit. The above article appeared as a programmatic statement indicating the ideological position of the periodical under the new leadership. Belinskii provided an accurate summary of Maikov's views in his article. Conceming Dostoevsky's opinion, see above, p. 40.

1847 А. С. Хомяков, „О возможности русской художественной школы” Московский сборник (ред. Панов) (1847).

Египет и Индия, Эллада и Рим, Италия, Испания и Голландия, кахдая из них дали образовательным художествам свой особый харак тер. Памятник в глаза историка-критика восстановляет историю (разумеется умственную, а не фактическую) исчезнувшего народа также ясно, как и письменное свидетельство. . . .

Не из ума одного возникает искусство. Она не есть произведение одинокой личности и ее эгоистической рассудочности. В нем сосредоточивается и выражается полнота человеческой жизни с ее просвещением, волею и верованием. Художник не творит собственною своею силою: духовная сила народа творит в художнике. Поэтому очевидно, что всякое художество должно быть и не может не быть народным. Оно есть ивет духа живого, восходящего до сознания или, как я уже сказал, образ самосознающейся жизни. У нас, при разрыве между жизнию и знанием, оно невозможно. . . .

. . . Важно то, что народ, способный к художествам, не может лишиться иначе их развития, как утратвв цельность и здравие своей Внутренней жизни. . . .

Всякое народное просвещение определяется народною личностью, т.е. живою сущностию народной мысли; более же всего определяется она тою верою, которая в нем является пределом его разумения. . . .

Жизненное начало утрачено намя, но оно утрачено только нами, принявшими ложное полузнание по ложным путям. Это жизненное начало существует еще цело, крепко и неприкосновенно в нашей великой Руси (т.е. Великой, Малой и Белой), не смотря на наши долгие заблуждения и на наши, к счастию, бесполезные усилия привить свою 
мертвенность к ее жнвому телу. То, что было, поросло быльем, и если бы нам приходилось отыскивать свою жизнь в прошедшем, конечно мы бы ее никогда не отыскали и не воссоздали; ибо создание или воссоздание жизни ничтожными силами одиночных рассудков было бы явлением противным всем законам духовного мира. . . .

. . . Жизнь наша цела и крепка. Она сохранена, как неприкосновенный залог, тою многострадавшею Русью, которая не приняла еше в себя нашего скудного полупросвещения. Эту жизнь мы можем восстановить в себе: стоит только ее полюбить искренной любовью. Разум и наука приводят нас к ясному сознанию необходимости этого внутреннего преобразования, но я не считаю его слишком легким ни для каждого из нас, ни пля всех. Гордые привычки нашей рассыпной, единичной жизни держат каждого из нас в свонх оковах. Нравственное обновление - не легкое дело. Конечно, каждый не только согласен полюбить те светлые жизненные стихии, которые сохранились на Руси, и ту Русь, которая их сохранила, но даже готов думать и уверять, что он любит их всей душөй. . . .

. . . Дело наше - возрождение жизненных начал в самых себе, следовательно оно может быть исполнено только искренной переменой нашего внутреннего существования. . . .

Общение заключается не в простом размене понятий, не в холодном и не в эгонстическом размене услуг, не в сухом уважении к чужому праву, всегда оговаривающем уважении к своим собственным правам, но в живом размене не понятий одних, но чувств, в общении воли, в разделения не только горя (ибо сострадание чувство слишком обыкновенное), но и радости жизненной. Только такого рода общение может возвратить нас к началам жизни, нами утраченной, и привести нас из состояния безнародной отвлеченности и мертвой самодовольной рассудочности к полному участию в особенностях, характере и физиономни народа. Наши школьнические полузнания развились бы до науки и развили бы науки, внеся в нее великие и до сих пор ей чуждые начала, отличающие нас от Западного мира с его латино-протестантской односторонностию, с его историческим раздвоением. В нашем быте отозвалось бы то единство, которое лежало искони в понятии славянской и которое заключается не в идее дружинного договора германского или формального права Римского (т. е. правды внешней), но в понятии естественного и нравственного братства и внутренней правды.

Aleksei Khomiakov (1804-1860), journalist, philosopher, poet, and theologian, became one of the leading slavophiles in the late 1830's. He explored and described the "obshchina" system of land use ("mir"). Khomiakov idealized pre-Petrine Russia and defended the superiority of the old Russian way of life based on the "obshchina" and the orthodox faith (defined as a society held together by a "vnutrennii zakon") over the West European social order (based on "vneshnii zakon" and characterized by violent upheavals). 


\section{PART TWO}

\section{Interpretations I - Literary Trends}




\section{SENTIMENTAL LITERATURE}

\section{Introduction}

The roots of sentimental literature in Russia extend into the 1750's. Early sentimentalism, which could also be described as moralistic and didactic sentimentalism, began with translations from Western, especially English and French literature. A handwritten copy of Richardson's novel Pamela, or Virtue Rewarded in a Russian translation circulated as early as the 1750's. The sentimental novels of Prevost and sentimental comedies by Diderot, Beaumarchais, Gellert, and Marivaux were popular in the 1760's and 1770's. Translations from English moralistic weeklies appeared in great numbers in Russian journals in the middle of the century. Original Russian novels by Fedor Emin, comedies by Kheraskov, Nikolev, and the light poetry of Sumarokov and Kheraskov appeared in the 1760's and 1770's. The last two decades of the 18th century saw an increased emphasis on the emotional and esthetic effect of literature on the reader. Moralistic and didactic elements were less obtrusive. Sentimental literature of this later stage could be described as sentimental estheticism, with Dmitriev, Karamzin, Murav'ev as its main representatives. Sentimental estheticism continued into the 18th century and exerted a strong influence on early romanticism (especially as represented by Zhukovskii).

Moralistic-didactic sentimental influences combined with classicist poetics in the works of Hugh Blair, Charles Batteux, and Jean-François LaHarpe, three writers and critics who were widely popular in Russia during the first two decades of the 19th century. This combination of early sentimental and classicist features is usually described as neo- or pseudoclassicism in Russian literature.

Sentimental literature rested on a well-defined body of philosophical assumptions. Its basis was sensualistic philosophy (J. Locke, D. Hume, A. Smith, F. Hutcheson), and the so-called Moral Sense School in ethics.

As early as 1759, Sumarokov had given a brief but substantial outline of John Locke's sensualistic theories. The heart (i.e., passions) was assigned a superior place in comparison with the head (i.e., reason). "Razum est' ne chto inoe, kak tol'ko soderzhatel' voobrazhenii, poruchennykh emu chuvstvami." All human experiences were assumed to be based on sensual impressions. The mind had only the function of ordering and associating 
these experiences. Since there were no inborn ideas in man, it followed that "nravouchenie osnovano na chuvstvakh, a ne na razume! Sovest' osnovana na churstvakh..."

Sumarokov did not go far enough to accept the expansion of sensualistic theory in Rousseau's writings. Nor did he integrate sensualistic philosophy with his literary work. This was left to the literature of the last quarter of the 18th century. The basic understanding of the origin and development of ideas and thought, both in the area of scientific knowledge and that of morality, was further developed in the course of the last two and a half decades of the century in the writings of Murav'ev, Karamzin, and their contemporaries. In sensualist philosophy, our world appeared as consisting of two spheres-the world of matter and nature, and the world of ideas and emotions, the latter being derived from the former. The principle of the analogous nature of the world outside and the world inside us, particularly with regard to morality, was established in an article which appeared in a Russian periodical in 1762 and was entitled "Sravnenie pritiagatel'noi sily $v$ bol'shikh telakh sveta $s$ onoiu, kotoraia usmatrivaetsia mezhdu dush chelovecheskikh." The basic and central force which held together the universe of emotions and ideas in man, akin to the force of gravity in the material universe, was defined as an ethical emotion-as sympathy and compassion. This application of sensualist and empiricist theories to ethics is usually discussed under the heading of the Moral Sense School. The "inner sentiment or feeling" (Adam Smith) that caused our emotional reaction to goodness and produced sympathy became known as the moral sense. This sense found its aim and fulfilment in the achievement of virtue and happiness. Just as the structure of the natural world was characterized by order, harmony, and beauty, so was that of human responses by sympathy, virtue and happiness. At least, this was the divinely ordained order of the world. Contradictory facts-such as natural catastrophes or moral evilhad to be explained as aberrations, or as the result of "neprosveshchennyi vkus," i.e., as a temporary stage on the arduous path of realizing the divinely intended onder.

Sentimental literature was already being parodied in the 1790's. Its place as an avant-garde literary movement was occupied by a new trend which had been evolving since the 1780's-preromantic literature. 


\section{SENTIMENTAL ESTHETICS}

1792 П. П.Чекалевский. Рассуждение о свободных художествах с описанием некоторых произведений Российских художников (Санкт-Петербург, 1792).

Между творениями природы, все служит к наслаждению зрения наших чувств. Все, что определено для нашего употребления, одарено красотою . . природа, стараясь таким образом, влиять в нас отовсюду приятные чувствования, без сомнения имела предметом возбудить и вкоренить чувствительность, которая бы в состоянии была укротить стремление страстей и чрезмерность нашего самолюбия.

P. P. Chekalevskii (1751-1817), a secretary, later vice-president of the Academy of Fine Arts in St. Petersburg, defines the relationship between nature and the individual in the sentimental manner. Nature exerts a positive moral influence on him who has become attuned to her and whose refined sensibilities allow him to understand her.

1793 Н. М. Карамзин, „Нечто о науках, искусствах и просвещенин” Аглая, I(1794).

Искусства и науки, показывая нам красоты величественной натуры, возвышают душу, делают ее чувствителнее и нежнее, обогащают сердще наслаждениями, и возбуждают в нем любовь к порядку, любовь к гармонии. добру, следственно ненависть к беспорядку, разгласию и порокам, которые расстраивают прекрасную связь общежития. Кто через мириалы блестящих сфер, кружашихся в голубом небесном пространстве, умеет возноситься духом своим к престолу невидимого Божества: кто внимает гласу Его и в громах и в зефирах, в шуме морей и - собственном сердие своем; кто в атоме видит мир и в мире атом беспредельного творения; кто в каждом шветочке, в каждом движении и дсйствии природы чувствует дыхание вышней благости, и в алых небесных молниях лобызает край саваофовой ризы: тот не может быть злодеем. На мраморных скрижалях истории, между именами извергов, покажут ли нам имя Бакона, де Карта, Галлера, Томсона, Геснера? . . .

Karamzin's essay signified a return to the sentimental concepts of his youth, from which he departed in his writings between the late 1780's and 1794 when he became ever more inclined to follow the preromantic trend. His essay expresses the sentimentalist's belief in the harmony of the universe which ought to be reflected in the harmonious structure of society. As in Chekalevskii's lines, there is a noticeable trend to deism.

Karamzin names the philosophers Francis Bacon $(1561-1626)$ and Rene Descartes (1596-1650), who laid the theoretical and mathematical foundations for the scientific study of nature, and the sentimental authors Albrecht Haller (1708-1777), a Swiss scholar (founder of experimental physiology) and a nature poet, James Thomson (1700. 
1748), a Scottish poet whose descriptive poem The Seasons influenced Karamzin's own nature poetry (he translated part of Thomson's poem), and Salomon Gessner (17301788), a popular Swiss poet of idylls and pastorals.

1790 s М. Н. Муравьев, „Удовольствне и скорбь” Полное собрание сочинений, III (Санкт-Петербурr, 1820).

Так как есть красота физическая, поражающая чувства наши в творениях природы; так и есть красота нравственная, ощутительна одному разумению нашему, во правах, в поступках людей, в их чувствованиях и словах ...

Внешняя красота есть только обещание прекрасной души.

M. N. Murav'ev (1757-1807) wrote several essays in which he outlined the concepts of the Moral Sense School in English sensualistic philosophy. He based himself mainly on Francis Hutcheson (1694-1746), author of Inquiry into the Ideas of Beauty (1725) and Treatise on the Passions (1728). His essays and poems illustrate the manner in which the philosophical concepts of the Moral Sense School were utilized by the sentimental writer. Note that Murav'ev identified beauty and moral goodness. The identity of these two basic concepts became a central tenet in sentimentalism.

1802 Н. М. Карамзин, „Мысли об уеднненни”, Вестник Езропы. 10 (1802).

Но временние уединение бывает сдадостно и даже необходимо для умов деятельных, образованных для глубокомысленных соцерзаний. В сокровенных убежищах натуры душа действует силнее и величественнее; мысли возвышаются и текут быстрее; разум в отсутствии предметов лучше ценит их; и как живописец из отдаления смотрит на ландшафт, который должно ему изобразить кистию, так наблюдатель удаляется иногда от света, чтобы тем вернее и живее представить его в картине. Жан-Жак Руссо оставил город, чтобы в густых тенях парка размышлять об изменениях человека в гражданской жизни, и слог его В сем творении имеет свежесть природы.

Временное уединение есть также необходимость для чувствительности. Как скупец в тишине ночи радуется своим золотом, так нежная душа. будучи одна с собою, пленяется созерцанием внутреннего своего богатства; углубляется в самое себя; оживляет прошедшее, соединяет его с настоящим, и находит способ украшать одно другим. - Какой любовник не спешил иногда от самой любовнищы своей в уединение, чтобы, насладившись блаженством, в кротком покое души насладиться еще его воспоминанием, и на свободе говорить с сердщем о той, которую оно обожает? По крайней мере чувствительные женщины должны иногда 
отсылать любовников в уединение, которое свонми размышлениями и мечтами питает страсти.

Karamzin emphasizes the sentimentalist's proclivity to self-analysis which went back to freemasonic influences and was stimulated by Rousseau's Confessions. He refers to Rousseau (1712-1778) who left Paris in the 1760's in order to live with the Duke of Luxemburg at Montmorency where he wrote his novel Emile. There he maintained that man was good by nature and should be educated in a manner which allowed for the free and natural development of his abilities in close contact with nature.

1812 В. Филимонов, „Отрывок из переписки Валерия с Реасом" Труды общества любителей российской словесности, IV (1812).

Мы занимались словесностию. С каким восторгом мы читали Клопштока, Делиля, Клейста, Державина, Дмитриева! Как радостно поверяли описания стихотворные с живыми картинами природы! Как часто на горе высокой, вокруг которой протекает река извилистая, мы встречали солнще восходящее! Как часто на прекрасном холму, ближнем от дома, мы прощались с последними его лучами, и в тихом веселии приходили в уединенное жилище наше! Здесь вечером, когда вся природа погружалась в приятный покой, унылые звуки фортепиан, или арфы, прекрасный голос Алевтины, умножали тот восторг, который возбуждал в нас величество природы. Непостижимое действие музыки, красоты поззии, божественная дружба - какое таинственное слияние всех лучших, совершеннейших чувствований человеческих!

V. Filimonov (1787-1858) was a popular romantic writer of poems, romances, novellas, and plays in the 1820's and 1830's. He translated F. G. Klopstock's (1724-1803) tragedy Der Tod Adams. In his younger years, Filimonov was a typical representative of the cliches of sentimental literature. Another German poet mentioned above is Ewald Kleist (1715-1759), author of anacreontic songs and nature poetry in imitation of Thomson. Jacques Delille (1738-1813), professor of Latin poetry at the College de France, a neoclassicist poet known in Russia mainly for his idyllic, descriptive and didactic poem Les jardins ou l'art d'embellir les paysages (1782; translated in 1814 and 1816).

1823 И. И. Дмитриев, Взгляд на мою жизнь

(Москва, 1866).

Одну только плавность стиха и богатую рифму я считал красотой и совершенством поэзия. Но в то время у нас едва ли не также думали не только читатели, но самые первостепенные стихотворцы. . . .

Поззия, порождение неба, хотя и склоняет взор свой к земле, но 
- здесь она проницает во глубину сердец; наблюдает сокровенные их изгибы, и живописует страсти, держась всегда нравственной цели, воспламеняет к добродетели, ко всему изяшному и высокому, воспевает доблести обреченных к бессмертию. А там - изливается в удивлении к мирозданию, В трепетном благоговении к непостихимому. Вот назначение истинной поззии!

Dmitriev's lines refer to the 1790's when sentimentalism had reached its climax in Russian literature. The overriding concern of the sentimentalist for style and esthetic effect soon led to a reaction against the overly refined language and often trifling subject matter of sentimental works. As Dmitriev's definition of poetry shows, the esthetic effect remained firmly linked to the moral aim: poetry, beauty and virtue were but three aspects of man's striving towards knowledge of the divine. 


\section{CRITICISM OF SENTIMENTAL LITERATURE}

В. Л. Пушкин, „Писъмо И. И. Дмнтриеву”

Аониды. I (1796).

Ты прав, мой милый друг! Все наши стиходеи

Слезливой лирою прославиться хотят;

Все голубки у них к красавицам летят,

Все вьются ласточки, и все одни затеи.

Все хнычут и ревут, и мысль у всех одна:

То вдруг представится луна

Во бледной - палевой порфире;

То он один остался в мире;

Нет милой! Нет драгой! Она погребена

Под камнем серым, мшистым;

То вдруг под дубом там ветвистым

Сова уныло закричит,

Завоет сильный ветр, любовник побежит,

И слезка на струнах родится. . . .

Pushkin enumerates sentimental motives which had become cliches in the 1790's: the escape to a solitary life at the bosom of nature; the imagined loss of a dear persor; stylistic features of the "graveyard school" (Gray), Ossianic poetry (Macpherson), and an overly tearful language.

1797 Н. М. Карамзнн, [ Преднсловие ]

Аониды. II (1797).

. . . Я осмелюсь только заметить два главные порока наших юных муз: излишнюю высокопарность, гром слов не у места, и часто иритворную слезливость. Поззия состоит не в надутом описании ужасных сцен натуры, но в живости мыслей и чувств. Если стихотворец пишет не о том, что подлинно занимает его душу; если он не раб, а тиран своего воображения, заставляя его гоняться за чуждыми, отдаленными, несвойственными ему идеями; если он описывает не те предметы, которые к нему близки и сообственною силою влекут к себе его воображение; если он принуждает себя или только подражает другому (что все одно) : то в произведениях его не будет никогда живости, истины или той сообразности в частях, которая составляет целое . . . Молодому питомцу муз 
лучше изображать в стихах первые впечатления любви, дружбы, нежных красот природы, нежели разрушение мира, всеобщий пожар натуры и прочес в сем роде . . . Не надобно также беспрестанно говорить о слезах, прибирая к ним разные эпитеты, называя их блестящими и бриллиянтовыми - сей способ трогать очень ненадежен - надобно описать разительно причнну сих слез; . . .

Karamzin himself turned against the exaggeration of sentimental style, although he continued to write in this vein. His own sentimental attitude is revealed in his advice to young writers. His lines were directed equally against tearful sentimentalism and preromantic exaggeration (as it appeared in the Gothic novel and German Storm and Stress dramas) which disrupted the harmonious unity of sentimental style and world view as understood by Karamzin and his poet-friend Dmitriev. Pushkin's and Karamzin's statements show that sentimentalism had passed its climax in the 1790's and had ceased to be part of the literary avant-garde.

1803 Н. М. Кармзин, „Моя исповедь"

Сочинения (Москва, 1803).

Я намерен говорить о себе: вздумал и пишу - свою исповедь, не думая приятна ли будет она для читателей. Нынешний век можно назвать веком откровенности в физическом и моральном смысле: взгляните на милых наших красавиц! . . . Некогда люди прятались в темных домах и под шитом высоких заборов. Теперь везде светлые домы и большие окна на улицу: просим смотреть! Мы хотим жить, действовать и мыслить в прозрачном стекле. Ныне люди путешествуют не для того, чтобы узнать и верно описать другие земли, но чтобы иметь случай поговорить о себе; ныне всякой сочннитель романа спешит как можно скорее сообшить свой образ мыслей о важных и неважных предметах книг под титлом: мои опыты, тайный журнал моего сердыа! Что за перо, то и за искреннее признание. Как скоро нет в человеке старомодного варварского стыда, то всего легче быть автором исповеди. Тут не надобно ломать головы; надобно только воспомнить проказы свои, книга готова.

Однакожь не думайте, чтобы я хотел оправдываться примерами: нет, такая мысль оскорбительна для моего самолюбия. Следую только собственному движению, и замечаю мимоходом, что оно некоторым образом согласно с обшим; не сохрани меня Бог казаться рабским подражателем! Для того, в противность всем исповедникам, наперед сказываю, что признания мои не имеют никакой моральной цели. Пишу - так! Еще и другим отличаюсь от моих собратий-авторов; а именно, краткостию. Они умеют расплодить самое ничто: я самые важные случаи жкзни своей опишу на листочке. 
Karamzin castigates a feature which characterized both sentimental and early romantic literature-the desire to reveal one's innermost feelings in writing. Rousseau's Confessions-already imitated by Fonvizin-were the literary model. Karamzin's tale from which the above excerpt comes may have been intended as a polemic, or a parody, of Rousseau's novel Emile (cf. Iu. M. Lotman, "Russo i russkaia kul'tura XVIII v.," Epokha prosveshcheniia [Leningrad, 1967], pp. 275-277).

1805 Журнал российской словесности, IV, 12 (1805), стр. 173-174.

Одному сантиментальному писателю потребно для сочиняемого им романа немалое количество притворной чувствительности. ложного сострадания. любовных вздохов и страстных восклицаний . . . Сантиментальный путешественник, бродя по улицам и собирая материялы для своего сочинения, выронил нечаянно две слезы, которые были нужны ему для нового его путешествия; а как теперь в глазах его совершенная засуха, то он просит поднявшего сии две сердечные слезки доставить в его дом, состояний в Юдоли плача. Приметами ж оные слезы: цвету синеватого, вкусом горьки и, положенные на бумагу, возбуждают смех в читателях.

The Zhurnal Rossiiskoi slovesnosti (1805) was published by N. P. Brusilov (died 1849) who (like most of his collaborators) was a member of the Vol'noe obshchestio liubitelei slovesnosti, nouk $i$ khudozhestv (founded in 1801). The journal was characterized by a liberal, patriotic attitude, and a critical view of sentimental literature. The anonymous author refers to the genre of the sentimental journey (Sterne) and the inclination of sentimental poets to tearfulness.

1817 М. Н. Загоскин, [ Журнальные статьн ] Северный наблюдатель (1817).

Было время - и это еше не так давно, когда всякий писатель должен был поневоле казаться чувствительным. Сотни книжек, наполненных сантиментальными фразами, сладкими описаниями романтических прогулок и чувствительных путешествий, наводнили нашу словесность. Общая болезнь всех модных писателей была милая меланхолия, алмазные слезы лились жемчужною рекою на бумагу, тяжелые вздохи вырывались из груди, и только одно воззрение на прелести любезной матери натуры услаждало их скорбь дущевную. Писатели сии старались подражать одному известному и всеми уважаемому сочинителю. Описывая пленительным слогом природу, он говорил иногда о ней с пламенным восторгом поэта, и все последователи его начали наперерыв восхищаться природою и описывать ее дурной прозою. В стране чужой он вздыхал иногда о друзьях своих и родных, и все подражатели его 
принялись, не расставаясь ни с кем, оплакивать разлуку с мильмми сердиу и проливать слезы над прахом живых друзей своих.

M. N. Zagoskin (1789-1852), author of historical novels, refers to Karamzin who had traveled in Europe in 1789-1790 and subsequently published his Pis'me russkogo pute. shestvennika (1791-1792, Moskovskii zhumal), which were imitated widely. Karamzin also followed the European trend of nature poetry represented by Thomson, Haller, E. Kleist, and Delille, all of whom were widely popular with sentimental authors in Russia.

1819 А. Глаголев, „Сновиденне, или суд на Геликоне”

Труды Обиества любителсй российской словесности, Летопнси , 4 ( Москва, 1819).

„На что стихотворцу правила?” кричала другая толпа, выступившая вперед. „Не сам ли Аполлон дал нам пиитическую вольность?” Кто вы? - спросил их Аполлон важным тоном. „Мы, позты," ответствовали юноши. - Каким родом поззии занимаетесь? - „Тем, для которого рождены мы." - Јирическим? - „Нет." - Эпическим? „Нет.” - Сатирическим? Драматическим? - „Нет, нет.” - Конечно баснями, элегиями, песнями или эпиграммами? - „Нет; мы пишем в новом и особенном роде, на пр. в альбом, к Нине, к Лиде, к Ней, и тому подобное."

Аполлон. И так, молодые люди, вы любите? -

Поэты. „Увы! Мы носим в сердщах своих стрелы любви ... безнадежной.” Апо:лон. Конечно ваши красавищы, подобно моей Дафне, превратились в деревья или камни?

Поэты. „Нет, наши красавицы никогда не сушествовали в физическом мире." - При сих словах Аполлон не мог не засмеяться; а поэты, тяжело вздохнув, продолжали: „Да они никогда не существовали в целом, но существуют по частям; на пр. нам понравились Лизанькины глазки, Аннушкины шечки, Надинькины губки и Сашинькин стан.

A. G. Glagolev (died 1844) was a minor writer and critic of neoclassicist convictions. His essay is an example of a neoclassicist's criticism of sentimentalism. 


\section{V \\ PREROMANTIC LITERATURE}

\section{Introduction}

Preromantic literature in Russia is closely related to similar West European literary trends. The foremost influence was the increasing concern for national, folkloric features which expressed itself in collections of fairy tales, folksongs, and national mythologies (e.g., Scandinavian sagas) that replaced the universal mythology of Greek and Roman antiquity. Macpherson's Songs of Ossian, Herder's collection of German, British, and Scandinavian songs, and similar Russian collections prepared the ground for the new trend. A new concept of nature linked to the Northern setting of Celtic, Germanic and Scandinavian folklore and the genre of nature poetry (J. Thomson, J. Delille, and E. Kleist to name the major representatives in England, France, and Germany) replaced the sentimental understanding of idyllic nature. Edward Young's Night Thoughts and Thomas Gray's "graveyard poetry" were further strong influences stressing the tragic and cataclysmic nature of man's fate in the world. The events of the French revolution had both the effect of increasing the sense of human insecurity which sometimes reached the intensity of modem existential anxiety in preromantic writing, and providing a powerful impetus to an anti-despotic, republican-minded literature.

The preromantic author had lost the security of sentimental concepts concerning the harmony of the world, the confidence in a future golden age, and the innate goodness of man. Nature was no longer the well-meaning mentor of mankind, but a fateful, irresponsible force, eternally creative and eternally destructive. The individual was subject to her forces. The laws of society were no longer considered obligatory and in harmony with nature. In fact, the well-intentioned laws of society could be contradictory to the laws of nature, as Karamzin pointed out in the "Island of Bornholm." Unlike the sentimental hero, preromantic man often did not accept the order of the world, but rebelled. It was no longer possible to classify such heroes as virtuous or vicious, as they could be both, depending on the point of view. Shakespeare's heroes corresponded to this concept, and so did the heroes of German Sturm und Drang dramas. Karamzin praised "the savage excitement of the soul" painted by Shakespeare's "gigantic" brush. Shakespeare appeared as a genius and this term in itself received new meaning approximating the romantic understanding. An influential statement of the 
early romantic view of the genius, Lavater's description of Goethe, was published in translation in Vestnik Evropy in 1808. Other relevant statements had appeared much earlier, e.g., in a review of Bobrov's poem "Tavrida" in Severnyi vestnik $(3 / \mathrm{V}, 1804)$.

Influenced by Rousseau's Confessions, literature became increasingly identified with life, and life romanticized in literature. D. V. Davydov's autobiography and his poems of the early 1800's are examples of this romantic feature. Karamzin accepted preromantic motives in his poetry and prose of the early 1790's. Under the impact of the death of his close friend Petrov and the political events in France (revolution) and Russia (increasing oppression), Karamzin returned to his earlier sentimentalism.

The preromantic trend was continued by the Turgenev brothers, Andrei and Alexander, A. F. Merzliakov who together with Andrei Turgenev founded the short-lived Friendly Literary Society (1801), Rodzianko, the philosopher of the Society, as well as some members of the Free Society of Lovers of Literature, the Arts and Sciences (founded in 1801), especially G. B. Kamenev. Several Russian writers who later went different ways in their evolution began in the preromantic vein. Outstanding among them were V. T. Narezhnyi, N. I. Gnedich, and D. V. Davydov. Most of them were conscious of the incompatibility of preromantic concepts with the sentimental trend. Andrei Turgenev complained that sentimental writing had inclined writers to effeminacy. He thought that writers should have "meshali s velikim, urodlivoe, Gigantskoe, chrezvychainoe." The members of The Free Society also opposed Karamzinian sentimentalism. Several of them were strongly influenced by the stylistic devices and motives of Sturm und Drang dramas and novels in Germany. Young Narezhnyi's tragedies and young Gnedich's prose and poetry are good examples of this trend. Narezhnyi wrote seven dramas and one book of tales before 1810. They all correspond to the preromantic mood and style. Some of his dramas were characterized by an exaggerated heaping of preromantic devices. Gnedich published five books in 1802 and 1803, two of which were entirely in the preromantic spirit as was the greater part of the third. In 1808, Gnedich published a translation of Shakespeare's King Lear, a tragedy which appealed to the preromantic frame of mind. Gnedich's novel Moritz, or the Victim of Revenge was structured after Schiller's Die Räuber. Two inimical brothers, both representatives of the "dämonische Mensch" of early romantic literature, vied for the possession of a girl. Their boundless passion drove them to extreme deeds.

Narezhnyi's tragedies and Gnedich's prose were only two examples of a trend which found fertile ground in Russia during the first decade of the new century. Apart from the influences already listed, mention should be made also of the Gothic novel which became popular at the turn of the century.

Russian writers and critics became increasingly aware of the novelty 
of the new trends and identified them as romantic. Critics spoke of Wieland's "romanicheskie epopei," of German "romanicheskie dramy," the "chudesnyi romanicheskii mir opery." Although the basic meaning of the adjective was related to the translated sentimental novel ("roman") as suggested by Professor Harder, it seems to have acquired a more specific meaning in the course of the early 1800's expressive of preromantic trends in German and English literature. As early as 1805 , "romanicheskii" appeared in a Russian text as a translation of the German adjective romantisch denoting a literary trend.

The German idealistic philosophers whose works contributed to the romantic trend were also introduced into Russia during the first two decades of the century. Kant's esthetic writings appeared in translation as early as 1804, Schelling's ideas were interpreted by Vellanskii, in 1805. Fichte's philosophy was popularized by Professor J. B. Schaad at Kharkov University between 1804 and 1816.

The preromantic trend was mainly confined to the 1790's and the first decade of the new century. Parodies of preromantic literature began to appear from the middle of the first decade of the 1800's onwards. 


\section{PREROMANTIC ESTHETICS}

О Филалет! Где теперь сия утешительная система?. . . Она разрушилась в своем основании!' . . . Мы надеялись скоро видеть человечество на горней степени величия, в венце славы, в лучезарном сиянии, подобно ангелу Божию, когда он, по священным сказаниям, является очам добрых, - с небесною улыбкою, с мирным благовестием! ${ }^{2}$ Но вместо сего восхитительного явления видим . . . фурий с грозными пламенниками!

Где люди, которых мы любили? Где плод наук и мудрости? Где возвышение кротких, нравственных сушеств, сотворенных для счастия? - Век просвещения! Я не узнаю тебя - в крови и пламени не узнаю тебя - среди убийств и разрушения не узнаю тебя! ${ }^{3} \ldots$ Небесная красота прельщала взор мой, воспаляло мое сердще нежнейшею любовью, в сладком упоении стремился $\mathrm{K}$ ней дух мой, но - небесная красота исчезла - змеи шипят на ее месте! - Какое преврашение! . . .

... Я не знаю, что мне думать о феноменах нравственного мира, чего ожидать н надеяться! . . .

Вечное движение в одном кругу, вечное повторение, вечное смена дня с ночью и ночи со днем, вечное смешение истин с заблуждениями и добродетелей с пороками, капля радостных и море горестных слез . . .

Суди о хаосе души моей, который представляет мне все творение в беспорядке!

Karamzin's verse and prose from the late 1780 's to 1794 show the influence of the preromantic trend. Under the impact of the death of his closest friend, the freemason A. A. Petrov (1766-1793), the events of the French revolution, and the increasingly repressive atmosphere at home, Karamzin returned to his youthful sentimental convictions which had been shared by Petrov. Two essays "Chto nuzhno avtoru?" and "Nechto o naukakh, iskusstvakh i prosveshchenii" (both 1793), illustrate this withdrawal to the comforting system of sentimental concepts. The increasing ferocity and bloodshed of the revolution in France led to a renewed crisis which found expression in the fictive letter "Melodor k Filaletu" (1794). This is the fullest statement of Karamzin's views as a preromantic author. The ideas of the letter, its pervading mood of gloom and despair, and the author's scepticism were paralleled in his preromantic stories "Ostrov Borngol'm" and "Sierra Morena." Karamzin's rebellious attitude was soon replaced by a modified version of his earlier sentimentalism. His new, conservative views were expressed in the second letter "Filalet k Melodoru," and in his verse and prose after 1794.

1. Karamzin refers to the system of sentimental concepts which he had outlined in the essay "Nechto o naukakh..."

2. As can be seen from Karamzin's correspondence and some of his early prose, 
he originally shared the enlightened sentimentalist's belief in continued progress eventually leading to the establishment of a golden age on earth which would see the flowering of the sciences and the arts.

3. Karamzin refers to the events of the French revolution. Marie Antoinette, the French queen, was beheaded in the fall of 1893; mass executions followed. This was the time when Karamzin began to write his letter.

1800 Ан. И. Тургенев, „К портрету Гете”

Поэзия начала 19-го века (Ленннград, 1961), стр. 260.

Свободным геннем натуры вдохновленный,

Он в пламенных чертах ее изображал,

И в чувстве сердща лишь законы почерпал,

Законам никаким другим не покоренный.

For Andrei Turgenev (1784-1803) as for most Russians of the time, Goethe was the author of The Sorrows of Werther, his early preromantic novel which made him famous throughout Europe. Turgenev, together with A. Merzliakov and V. Zhukovskii, translated part of the novel. Goethe was for him, as for Lavater earlier, the image of an unfettered genius, not limited by any moral or esthetic considerations.

1800 С. Родзянко, „Разговор между философом и натурою” Утренняя заря, 1 (1800), стр. 183-185.

„Я [ природа ] великое целое - я больше ничего сказать не имею ... Я вся - искусство."

Rodzianko (1782-1808) was the philosopher of the Druzheskoe literarurnoe obshchestvo. He went insane in 1803 at the age of twenty-one. In a typically romantic manner, he identifies nature and art.

1801 Ан. И. Тургенев, „О поэзин и о злоупотребления оной” (речь) Журнал Министерства народного просвещения, 3, 11 (1913).

. . . Проходя в мыслях все роды изящных искусств и наук, мы не найдем ничего важнее, ничего священнее поэзия. . . .

От чего же поэты, законодатели смертных, изъяснители таинств божества, теперь ничто иное, как подлые льстещы пышности, рабы суетности и тщеспавия?

In the early romantic understanding, the writer was exalted to the position of a prophet, and his craft was identified with the divine creative force in the universe. 
1801 Ан. И. Тургенев, „О русской лнтературе” (речь)

Русский библиофил, 1 (1912), стр. 29.

Карамзин сделал эпоху в нашей литературе и вопреки русскому характеру и климату и пр. ... .

Он слишком склонил нас к мягкости разнеженности. Ему бы надлежало явиться веком позже, тогда когда бы мы имели уже более сочинений в важнейших родах; тогда пусть бы он в отечественные дубы и лавры вплетал цветы свои.

Скажу откровенно: он более вреден нежели полезен нашей литературе, и с тою-же откровенностию признаюсь что и сам я, и может быть не я один лучше желал написать то что он, нежели все эпические наши поэты. Он вреден потому еще более, что пишет в своем роде прекрасно; пусть бы русские продолжали писать хуже и не так интересно, только бы занимались они важнейшими предметами, писали бы оригинальнее, важнее, не столько применялись к мелочным родам, пусть бы мешали они с великим, уродливое, гигантское, чрезвычайное; можно думать что это очистилось бы мало, по малу.

Turgenev favored themes of national significance embodied in major genres. He preferred the powerful language of Lomonosov and Derzhavin to that of Karamzin. His demand for the inclusion of the "ugly" and "gigantic" paralleled the concepts of German Storm and Stress authors.

1801 А. Ф. Мерзляков, „Письмо Вертера к Шарлоте”

Стихотворения (Ленинград, 1958).

Сколь добродетели мала над смертным власть,

Когда его влечет сильная сердца страсть!

... Отчаянье во мне все чувства задушило.

Я презирал людьми. и небом, и землей,

Раскаяньем моим, природой и - тобой.

На гнусность сих убийств без ужаса взирая,

Свирепости моей границ не полагая,

Себя еще во всем я правым почитал. . . .

. . . Скучая жизнию, хочу оставить свет,

. . Ч Что делать в свете мне? Я в жнзни все прошел

И счастья ни в чем прямого не нашел. 
... Я целый свет моим рассудком обнимал,

Все видеть, все познать, все испытать желал.

.... А я - а я теперь в ночь вечную иду,

... Не к вечному отцу - в ничтожность обратиться.

Imitations of Goethe's novel The Sorrows of Werther were numerous in all major European literatures. In his poem, Merzliakov (1778-1830), a prominent member of the Druzheskoe lit. obshchestvo, continued the tradition of rewriting Werther's last letter. In his version, Werther left home after the marriage of Charlotte and Albrecht, traveled all over the world, and, finally, returned in order to avenge himself by murdering both Albrecht and Charlotte. He did not execute his plan, but, disappointed and bored by life, committed suicide. Merzliakov's description of Werther illustrates the early romantic concept of the demonic individual whose passions cause him to transgress social and moral laws. He is an early example of the Prometheus-like romantic hero who ended in disillusionment as did Byron's heroes or the superfluous men of Russian romantic literature.

1810 Д. В. Давыдов, Стихотворения (Ленннтрад, 1959), стр. 41.

Нет поззии в безмятежной и блаженной жизни! Надо, чтобы что-нибудь ворочало душу и жгло воображение.

Denis Davydov (1784-1839) wrote his military lyrics during the first two decades of the 19 th century. He created the image of the warrior-poet, partisan, and poet-dilettante in his verse and autobiography (Nekororye cherty iz zhizni Deniso $V$. Davydova) in a romantic setting of camp fires and battle scenes. Life and literature merged completely. Davydov's poetry became a diary of its fictionalized author hero, an intimate lyrical record of the partisan hussar Davydov and his exploits. The hussar of his poems was yet another incamation of the strong individual of preromantic literature. 


\section{CRITICISM OF PREROMANTIC LITERATURE}

---, „О некоторых новейшнх романах"

Любитель словесности, II (1806).

Многие полагают, что нет ничего легче, как написать роман в новом английском вкусе, где (как говорит один иностранный журналист) невероятное, основанное на невозможном, превосходит все чудесное, и гнушается правдоподобным!

Особливо мертвешы в такую пришли моду, что горе тому, кто бы захотел наполнить свое сочинение одними только людьми живыми! . . .

Кажется, на русском языке нет еще таких сочинений; за то мы имеем множество переводов: Таинства удольфские, Полночный колокол. Монах, Итальянеи. Гробница, Лес, Замок Алберта. Живой мертвеи. и ирочие творения госпожи Радклиф, давно уже обогатили нашу словесность.

The anonymous reviewer referred to the Gothic novels of Mrs. Radcliffe. All the novels mentioned above were translated between 1802 and 1804. Matthew Gregory Lewis' Gothic novel The Monk was falsely ascribed to Mrs. Radcliffe as were several other titles (Polnochnyi kolokol. Grobnitsa. Zamok Alberta, and Zhivoi mertuets). Mrs. Radcliffe's novels had appeared originally in the 1780's and 1790's. They became a powerful influence on Russian preromantic literature.

1806 ---, „О каталоге книг, прнвозимых на Лейтцигскую ярмарку” Вестник Езропы. 28 (1806), стр. 100.

Трансцендентализм и Шеллингианизм скрываются под щегольскими шапочками с развиваюшими перьями; . . . молодые мужчины соблазнают девушек; а девушки даются в соблазн, следуя образцам, начитанным в романах и драмах.

The author links the concepts of German idealistic and romantic philosophy (Kant, Fichte. Schelling) with the romantic trend in literature and blames the supposedly immoral influence of contemporary writing on the philosophic currents of the time. Admiral Shishkov used similar arguments against the adherents of the new style (Karamzin and his followers). 
$1808---$, Критнка

Драматический вестник, 2/36 (1808), стр. 76-77.

Почти все герои Шиллеровых трагедий кажется с ним вместе воспитывались в немецком университете, где они напитались новой философией, от которой избави господи всякого честного человека. Большая часть действующих лиц в новых французских драмах, мелодрамах и трагедиях, кажется родились вместе с их револющиею. Римляне и греки господина Легуве и Шенье не похожи на римлян Корнелевых и греков Расиновых; герои Волмеранжов и Пиксерикуров выбраны из толпы бунтовшиков, наполнявших ужасом последние годы прошедшего столетия.

The Dramaticheskii vestnik (1808) was the first Russian periodical wholly devoted to the theater. It was published on the initiative of the playwright Shakhovskoi. Krylov was among the contributors. The journal defended neoclassicist views and attacked sentimental and preromantic literature.

Gabriel Legouvé (1764-1812) was a poet and author of tragedies. His Éteocle et Polynice was modeled after Racine's Thébaide.

Marie-Joseph Chenier (1764-1811), brother of the more famous poet André Chenicr, was known as a playwright and poet. He was an adherent of the French revolution and Napoleon. In his historical tragedies (e.g., Gaius Gracchus, 1792) he praised the revolution. comedies.

Pierre Comeille (1606-1648) was a classic French author of comedies and tragi-

Jean-Baptiste Racine (1639-1699) was a classic French author of tragedies. Corneille and Racine became the models for classicist and neoclassicist plays in Europe.

Benoit Pelletier-Volmeranges (1756-1824), playwright.

Rene Charles Pixerecourt (1773-1844), a French playwright; wrote comedies and melodramas which were popular after the revolution.

---, „Смесь"

Московский вестник, 1 (1809).

Я не коснусь до содержания (которое почти все выведено с удивительною историческою точностью!!!), не буду говорить ни о слоге, ни о жестоком подражании Шиллеру, которое превосходит всякое ожидание зрителя: яд. множество гробов и все выносятся на сцену; беспрерывные смертеубийства, адские заклинания, все пороки, все варварства, весь тиранизм злой души человеческой - все это кажется должно заставить каждое доброе сердще отвращать взор от сцены, наполненной преступлениями извергов. - Души добрые трепешут и от одного слуху о жестокостях!

Vasilii Narezhnyi (1780-1825), in his youth an adherent of the preromantic trend, especially Storm and Stress drama, wrote seven plays between 1799 and 1810, many of which show the strong influence of Schiller's early plays. Dmitrii Samozvanets was written in 1800 and published in 1804. It is this play which is discussed in the above review. 
1810 Е-- Ок--, „Мысли стелного жнтеля из города Боброва" Русский вестник, 4 (1810), стр. 80-88.

Новый философ не имеет никаких оснований: по его мнению совесть предрасуждение; вера - узда младенцев; добродетель - мечта! . . .

Новые умники не терлят начальства; не любят ни гражданских, ни божественных законов. Люди состаревшиеся в опытах и подвигах полезных для них - ноль. . . .

Новые философы все переменили; Бога, природу и общество. На словах сулят они вечное блаженство. На деле верят только личной корысти своей. Кружением голов своих перекружили они миллионы голов.

The author-possibly S. N. Glinka, the editor-refers to philosophies considered dangerous by conservatives, i.e., French materialism and atheism of the 18 th century, Rousseau and Montesquieu, as well as German idealism from Kant to Schelling.

,--- ,Крнтика"

Санкт-Петсрбургский вестник, 2 (1812).

Следствие пылких и необузданных страстей, трагедия в пяти действиях (M. 1811 ).

Ужасная трагедия! В ней беспрестанно рубят, режут, жгут, отравляют ядом! Двенадщать мертвецов, две отрубленные головы, одна голова в ящике - какой богатый предмет для трагика! - На каждой странице сочинитель восклицает: черт! дьявол! дьявольщина! черт побери! Эй! А! О! Ну! Те! Фуй! Та! Гм! Ба! Ха! Ха,ха! --

Этот драматический бред писан прозою; содержание выкрадено из немецкого романа: Куно фон Кибург.

The Sanktpeterburgskii vestnik (1812) was published by the Obshchestvo liubitelei slovesnosti. nouk $i$ khudozhestv. It attacked the idealistic philosophy of Schelling, the mysticism of Eckartshausen, and was generally inimical towards the excesses of the preromantic trend. The end of the furst decade of the 19th century saw the peak of translations and imitations of preromantic dramas of often questionable literary quality. The publication of the tragedy had been preceded by a translation of the original German novel (Heinrich D. Zschokke, Kuno von Kyburg, 1795-1799) as Kuno lon Kyburg vial serebrianyi lokon obezglavlennogo i unichtozhil roinyi sud Inkvizitsii. Istoriio predkol, rosskazyvoemaio sochinitelem Chemykh bratii [Sankt-Peterburg. 1809/, translated by Vasilii Kuzikov). The author of the review was possibly N. I. Grech, a well-known journalist of the 1820's and 1830's. 


\title{
VI
}

\section{ROMANTICISM}

\author{
Introduction
}

Romantic literature in Russia has been treated unevenly. Much of what was written during the period, known also as Russia's Golden Age of Poetry, has become immortal. Although there can be no doubt that the diverse and illdefined complex of romantic esthetics provided the life blood of Russian literature from the 1820's into the 1840's, literary historians have tended to disregard the role of romantic esthetics in Russia. Such outstanding authors as Pushkin, Lermontov, and Gogol have repeatedly been classified as realistic writers and the romantic "portion" of their work has been evaluated as a preliminary step in the evolution towards realism. Prerevolutionary scholars often used the term pseudoromanticism (coined by Nadezhdin) and Soviet scholars speak of Decembrism and "stanovlenie realizma" (the latter dated between 1815 and 1825).

The problem is compounded by the existence of several distinct, often contradictory, trends within the romantic movement, by the continuation of neoclassicism and sentimentalism, and, lastly, the polarization of political views which followed the return of the Russian armies from Western Europe and again made itself felt after the abortive Decembrist uprising.

The main trends may be described as follows:

1. Romantic literature conceived as an individual, spiritual and emotional experience. This trend dominated between the early 1800's and 1820's and was represented by Zhukovskii and his numerous followers. It derived its inspiration from German romanticism.

2. National ("slavophile") romanticism as professed by a group of young critics, writers, and translators, among them Katenin, Zhandr, Griboedov, Kiukhel'beker, who took their inspiration from Russian folklore, admired Krylov's original and powerful language, and deplored the result of Karamzin's and Zhukovskii's ineffectual, soft and purely esthetic approach. In consonance with Admiral Shishkov they protested against the excessive imitation of West European models.

3. Related to the above trend is "Decembrism" as a literary phenomenon. Its main representatives were K. F. Ryleev, the ideologist of the movement, and A. A. Bestuzhev. Close to them were other writers with less revolutionary zeal who admitted, however, the need for a "politicization" of 
literature. Prince Viazemskii and young Pushkin were close to this view in the early 1820 's.

4. Philosophic romanticism. The adherents of German romantic and idealistic philosophy (particularly Schelling), known as wisdom lovers ("liubomudry"), turned away from the occupation with everyday questions and approached an art for art's sake attitue. Several future slavophiles began their literary careers in this manner.

5. The main current of romantic literature, which in the 1820's was characterized by the influence of English romantic authors such as Byron in poetry and Walter Scott in the area of prose. In the 1830's it developed into the ultraromantic trend associated commonly with the tales of Bestuzhev-Marlinskii. Victor Hugo and other French authors, usually grouped together in Russian criticism of the time as the "école frénétique" of "la jeune France," became a major influence for this stage of the romantic movement. The literature of the late 1830's and early 1840's increasingly assumed "realistic" elements, which may justify the use of the term "romantic realists" for writers of this time.

It must be realized that this schematic overview will not do justice to the variety of literary forms, concepts, and patterns that existed in Russian literature of the period. The hellenism of Gnedich's and Delvig's poetry, the trend towards classicist forms (analogous to German Klassik) which we find in the poetry of these two authors, but also in many works by Pushkin, has to be seen as a constituent part of the romantic age. The development of Russian prose writing from the historical novel (Zagoskin and Lazhechnikov) and the novel of manners (Narezhnyi and Bulgarin) to the tales of Pushkin and Gogol does not lend itself easily to classification. It will also be obvious to the student of Russian literature that many writers reflected the influence of more than one trend. The romantic axiom of absolute freedom for the creative spirit (genius) could not but lead to a diversification of literary forms and views.

Literary influences coming from Germany, England, and France were part of the Russian literary scene throughout the romantic age. In the early 1820's it was mostly English authors who were popular in Russia. Besides Shakespeare it was not only Byron but also two American authors, Washington Irving and J. F. Cooper, who were widely read in Russia. The novels of Walter Scott led to the establishment of the historical novel in Russia towards the end of the 1820's. From the middle 1820's on, German idealistic and romantic literature (Schelling, August and Friedrich Schlegel, the tales of E. T. A. Hoffmann) became of considerable importance. French poets such as A. Chénier, De Vigny, and Pamy, and French prose writers (Lamartine, Benjamin Constant), were a continuous influence in Russia. Hugo became well-known with his preface to the romantic drama Cromwell (1827). In addition to Hugo whose popularity increased in the 1830's, it was Balzac, Sand, Sue, Soulie and Paul de Kock whose works became known in Russia 
in the 1830's. Dickens' novels and Goethe's works were also translated in the late 1830's and 1840's.

Romantic literature was published in a number of journals and almanacs. Romantic esthetics were discussed there, polemics for and against this literary movement took place there. One of the most important early statements of romantic esthetics. Somov's three essays "O romanticheskoi poezii" (1823), appeared in Sorevnovatel' prosveshcheniia $i$ blagotvoreniia (18181825), the journal of the Vol'noe obshchestvo liubitelei rossiiskoi slovesnosti. Many writers who were close to the Decembrist movement collaborated there and in Bestuzhev's and Ryleev's joint publication, the almanac Poliarnaia zvezda $(1823,1824,1825)$ which popularized the romantic trend in the spirit of Decembrist nationalistic literature. Mnemozina (1824-1825), close to the Decembrist movement, expressed the views of the "liubomudry" circle, i.e., German idealism and romanticism. Kiukhel'beker's programmatic article, "O napravlenii nashei poezii. . .," appeared there. Polevoi's journal Moskovskii telegraf (1825-1834) propagandized French romantic writers, especially Victor Hugo, and defended the romantic movement. Bestuzhev became a close collaborator of the joumal in 1829.

Baron Del'vig's almanac Sevemye tsvety (1825-1832) might be considered the most important periodical of the romantic movement. It united a group of authors known as the "Pushkinskaia pleiada." Excerpts from Pushkin's Evgenii Onegin were first published there (1827). Somov published annual reviews of Russian literature in the joumal (1828-1831).

M. P. Pogodin, a former member of the "liubomudry" circle, began a new journal, Moskovskii vestnik, in 1827, which continued the idealistic and philosophical trend of the circle. Collaborators were Venevitinov, Khomiakov, Shevyrev, and the two brothers Kireevskii. During the four years of its existence, the journal published both original romantic works and translations from Goethe, E.T.A. Hoffmann, Jean Paul, Tieck, Schiller, and A. Schlegel.

The 1830's began in a promising manner. M. A. Maksimovich launched the almanac Dennitsa (1830-1834) which published the works of well-known romantic authors including Pushkin. F. I. Tiutchev's poems appeared on its pages. Del'vig (later replaced by Somov) began to publish a Literatumaia gazeta (1830-1831) with the assistance of Pushkin and Viazemskii. Gogol first appeared in print there. Katenin's "Razmyshleniia i razbory" (an important discussion of romantic esthetics ) appeared in its pages. Nadezhdin who had started his journalistic career in the anti-romantic journal Atenei (1828-1830) inaugurated his own journal Teleskop in 1831. His position falls between Polevoi's romanticism and the conservatism of Severnaia pchela (1825-1864), edited by Bulgarin, who was joined by Grech in 1831, and Syn otechestva (1812-1844), edited at various times by Grech, Voeikov, Bulgarin, Senkovskii, and others. Belinskii's first articles appeared in Teleskop and its supplement Molva (1832-1836). Nadezhdin also published 
Balzac's Père Goriot, Heine's Reisebilder, and excerpts from Zagoskin's and Lazhechnikov's historical novels. In 1836, Nadezhdin printed Chaadaev's "Filosoficheskoe pis'mo" which led to the closing of the journal. Nadezhdin himself was exiled. Ivan Kireevskii's short lived journal Evropeets (1832) was forbidden after the second issue, since the editor's article "XIX vek," "podryval osnovy sushchestvuiushchego stroia." The Moskovskii nablüudatel" (1835-1839) represented the views of slavophile writers. Shevyrev was responsible for the literary section of the journal until 1837. Belinskii became its unofficial editor in 1838. The last major journal of the romantic period was founded by Pushkin in 1836. The first issue of Sovremennik contained Gogol's major article "O dvizhenii zhurnal'noi literatury v 1834 i 1835 godakh." In 1847, the joumal was taken over by Nekrasov and Panaev. Belinskii became its literary critic and advocated the realistic style of the new "Natural School" on its pages.

The great number of periodicals, each representing its own understanding of romantic literature, illustrates the breadth of this literary movement. Belinskii already differentiated between two types of romanticism, "v dukhe srednikh vekov" and "novyi romantizm." For the former the world was tragically split into the world of the ideal ("neopredelennoe, tainstvennoe tam") and reality ("preziraemoe zdes" "). Concerning the new romanticism, Belinskii said that "dva prostranstva slivaiutsia $v$ odno real'noe nebo istoricheskogo progressa, istoricheskogo bessmertiia." This basic scheme, which opposes Zhukovskii's sentimental-romantic views to the romanticism of the Decembrist writers, is still current in Soviet literary histories under the names of passive and active romanticism (these are also Gorkii's characteristics of the two romantic trends). Gukovskii has suggested similar terms, "psikhologicheskii" and "grazhdanskii romantizm." Prerevolutionary scholars developed various schemes of classification. Pypin in the 1870's deduced two kinds of romanticism from the attitude of writers to the French revolution. Zamotin differentiated between three trends characterized by the concepts of "individualism" (Bestuzhev-Marlinskii), "nationalism" (Zagoskin), and "universalism" (Odoevskii). Zamotin's scheme was further developed by Sakulin who spoke of four kinds of romantic literature: (a) sentimental romanticism, (b) philosophical romanticism, (c) individualistic romanticism, and (d) "romantizm narodnosti."

Attempts to define the essential traits of romanticism have emphasized various aspects: Veselovskii defined romanticism as "liberalism in literature" (as did Victor Hugo in his Preface to Hernani), Sipovskii saw its most characteristic trait in "individualism," Zamotin stressed the idealistic world view of romantic authors, while Sakulin defined its essence as a denial of reality, as escape into the irrational. Under the influence of formalistic theories, Beletskii sought the essence of this literary movement in the area of style, particularly the quality of the "pit toresque" which was expressed in the metaphoric style of romantic writing. 
Marxist critics have emphasized "subjectivism" (Kogan), and "individualism" (Gukovskii), both of which were linked to the social evolution (Volkov). More literary definitions have been provided by Meitakh who characterized the essence of romantic writers as "mechta" (dream, longing), and Gei who sees the essential feature of romanticism in the striving for the ideal as something which "is not, although it ought to be."

These definitions bring us closer to Western attempts to define the elusive nature of the European romantic movement. René Wellek's assertion that "we find throughout Europe the same conceptions of poetry and of the workings and nature of poetic imagination, the same conception of nature and its relation to man and basically the same poetic style, with a use of imagery, symbolism and myth..." applies to Russia as well. Wellek has stipulated three criteria for a definition of romantic literature: "imagination for the view of poetry" (i.e., poetry as knowledge of the deepest reality accessible to the genius alone); "nature for the view of the world" (i.e., nature as a living whole, eternally creative and destructive, the embodiment of the spirit); and "symbol and myth for poetic style" (i.e., literature as reaching for the ideal which is unaccessible in reality in the symbols of nature and national mythologies).* Part III of the Anthology will further illustrate these aspects.

"Cf. Problemy romantizma. Sbomik I, "Iskusstvo" (Moskva, 1967); and R. Wellek, "The Concept of Romanticism," in his book Concepts of Criticism (New Haven: Yale U. Press, 1963), pp. 160 ff. 


\section{TERMINOLOGY: „ROMANICHESKII” AND „ROMANTICHESKII”}

1805 --, „06 опере” (перевод с немещкого)

Северный вестник, IV, 4 (1805).

Романическое есть само по себе чудесное, а все чудесное есть само по себе стихо творческое. ...

Романическое требует свойственного ему выраження; удобнейшее же к тому средство есть соединение музыки с стихотворством. Музыка всегда есть отголосок друтого мира, мира волшебного, которого мы ни точно понять, ни чувствовать не можем. Громко отзывается она в нас; но отзыв ее, кажется, нисходит от высших стран. В таком же точно содержании и романическое. Оно находится в нас, в мире наших чувств, в нашем верования, во внутреннем нашем рассматривания; а чтоб ему живое иметь над нами действие, - надобно, чтоб оно связано было с чувственными приключениями, с чудесными явлениями, с предметами и разговорами. . . .

The term "chudesnoe" which was usually associated with romantic literature corresponds to what German writers, especially of the Jena school, called "das Wunderbare." According to Novalis, it was the novel which poetized life; the novel was incomprehensible, marvelous (urunderbar). and transferred the reader into another sphere of life (see his Fragmente, no. 2022). It is this view which is here applied to another genre, the opera. The opera became a popular form of entertainment for the rococo style of life during the last third of the 18 th century in Russia. In 1804, Derzhavin complained in a letter to Kapnist that public taste was raving with operas. In his long essay "O liricheskoi poezii" (1811), Derzhavin stressed the romantic features of the opera in a manner similar to the above excerpt. The adjective "romanicheskii" is a translation of the German term romantisch.

1805 И. И. Мартынов, [ Прнмечания к статье „06 опере”] Северный вестник, IV, 4 (1805).

Если все романическое есть чудесное, то две третие доли лучших гишпанских романов не заключают в себе ничего романического.

The above lines are part of a footnote to the translation of the essay $O b$ opere. They illustrate well the ambiguous usage of the term "romanicheskii." 1 . I. Martynov, the editor of the joumal and writer of the note, applied the term both in the sense of a literary-poetic quality and in the meaning of novelistic.

1808 А. А. Шаковской (?), Рецензня на „Рекрутский набор” Драматический вестник, 8 (1808).

Даже и самый род сих сельских происшествий, уступающий правильной комедии, должен взять преимущество перед немецкими романическими драмами, где почти всегда сказка сплетена чудесным образом, где действие нередко бывает без причин, где оно останавливается пुя 
получасу, чтобы дать время какому-нибудь низкорожденноблагородному нравоучителю высказать все то, что автор затвердил из новых философов и чем он наполняет две трети драмы, оставляя последноюю для узнания законно или незаконно рожденных детей, для обмороков, утоплений, грому, дождя, завтрака, ужянов, курения табаку, описания ничтожных подробностей и, наконец, немых картин, которыми кончаются действия.

A. A. Shakhovskoi (1777-1846), a prolific playwright who parodied the sentimental trend in his popular comedy Novyi Stem (1807), described typical characteristics of German romantic dramas of the Storm and Stress period. The adjective "romanicheskii" seems to denote a literary trend rather than the quality of being novelistic.

1817 П. А. Вяземский, [ Предисловие ]

Сочинения В. А. Озерова. (Санкт-Петербург, 1817).

... [ Трагедия Озерова] уже несколько принадлежат к новейшему драматическому роду, так называемому романтическому, который принят немцами от испанцев и англичан.

P. A. Viazemskii seems to have been the first Russian to use the neologism "romanticheskii" formed by analogy with the German adjective romantisch.

1825 В. Олин, [ Ответ на прнмечания Булгариня]

Русский инвалид, 52 (1825).

. . . Поззию романтическую можно иначе назвать романическою. потому что все обстоятельства, все положения, приличествующие роману, приличны также и поэме романтической . . Итак, поэма романтическая есть роман в стихах, или, роман поэтический. И если план должен находиться в романе, то без сомнения должен находиться также и в поэме романтической; если романист обязан также выдерживать страсти и рисовать характеры, то само собою разумеется, что и поэт романтический не увольняется от сей обязанности.

In the opinion of some critics, the romantic writer did not create according to a preconceived plan; he did not consciously organize his material. His works were characterized by "genial'naia nebrezhnost" " (cf. p. 95). Compare Olin's view to the opinions held by Viazemskii and Bulgarin (p. 95f). The introduction of the new term "romanticheskii" as denoting the characteristics of the new literary trend led to a narrowing of the meaning of the earlier term. As in the 18th century, "romanicheskii" once again was used to mean novelistic. 
Помню, что в каком-то чувствительном журнале, кажется, в 1813 году, было напечатано, что в Англии явился поэт, Бирон, который пишет в каком-то романтическом роде и особенно прославился своею позмою .Шильд Гарольд": вот вам и все тут.

Belinskii was inaccurate. Byron was first mentioned in 1815 in the joumal Rossiiskii muzeum, ili Zhumal Evropeiskikh novostei (No. 1, pp. 37-42). Belinskii also substituted the later term "romanticheskii" for the adjective "romanicheskii" which had been used by the reviewer as a definition of Byron's poetry. Number three of the same journal discussed Woverley by "odin Val'ter Skott" (Walter Scott). 


\section{CHRONOLOGICAL LIMITS}

Ф. Ф. Витель, Записки, I (Москва, 1928).

Вместо Геро, с нежным трепетом ожидающей утопающего Леандра, представить нам бешенострастную Ленору со скачушим трупом любовника! Надобен был его [ т.е. Жуковского] чудный дар, чтобы заставить нас не только без отвращения читать его баллады, но, наконец, даже полюбить их. Не знаю, испортил ли он наш вкус; по крайней мере создал нам новые ощущения, новые наслаждения. Вот и начало у нас романтизма.

F. F. Vigel' (1786-1856) was the author of valuable memoirs which provide an insight into the cultural and intellectual life of the first three decades of the 19th century. Hero and Leander were two legendary lovers of Greek mythology living on opposite shores of the Dardanelles. According to Greek tradition, Leander drowned in the attempt to cross the sea. The theme of love trying to overcome all obstacles appealed to the sentimentalist. I. I. Dmitriev ridiculed the theme in an epigram,

Леандр. в последннй раз возникнув из валов.

Молил взираюиих сквозь зарево богов:

О боги, боги! допустите

Взглянуть мне на нее и после потопите! (1797)

Vigel' contrasted the sentimental interpretation of the story with Zhukovskii's ballad "Liudmila" (1808) which was a slightly Russified version of Bürger's romantic medieval ballad "Lenore." Zhukovskii's poem became very popular and was said to mark the beginnning of romanticism in Russia. It popularized motives of medieval, knightly romance which became an almost obligatory ingredient of the genre in early romantic poetry.

1822 Н. И. Греч, Опыт краткой истории русской литературы (Санкт-Петербург, 1822).

В это время явились два человека, которые совершенно овладели языком поззия. Оня наши современники; они с царствования Александра I (эпохи блистательнейшей в истории отечества) начали новый период русской поззии: я говорю п Жуковском и Батюшкове.

Чистота, свобода и гармония составляют главнейшие совершенства нового стихотворного языка нашего. . . .

Жуковский, воспитанник и основатель в Россий романтической школы поззии, совершенно постигнул прекрасную в ней сторону. Глубокие чувства, смелая мечтательность, богатство, или, лучше сказать, роскошь самых свежих картин природы, составляют настоящие красоты романтической и вместе Жуковского поззии. Изображая чувствования сердща человеческого, он доходит до самых сокровеннейших. Как анатомик, он знакомит нас со свеми изгибами нашего сердща. 
Grech's view was commonly held at that time. Cf. A. Bestuzhev's views as expressed below.

1822 П. А. Вяземскй̆, „О Кавказском пленннке”

Сын отечества, 49 (1822).

Неволя была, кажется, музою вдохновительницею нашего времени. ІІильонский узник и Кавказский пленник, следуя один за другим, пением унылым, но вразумительным сердиу, прервали долгое молчание, царствовавшее на Парнассе нашем. . . . Явление упомянутых произведений, коими обязаны мы лучшим поэтам нашего времени, означает еше другое: успехи посреди нас поззии романтической.

Two important publications in 1822 were Zhukovskii's translation of Byron's poem "The Prisoner of Chillon" and Pushkin's poem "Kavkazskii plennik." Viazemskii's article was an important statement of romantic views. Pushkin referred to it in a letter to Viazemsky (February 6, 1823) saying that Viazemskii "pervyi vozvysil golos za romanticheskuiu poeziju."

1823 А. А. Бестужев, „Ответ на крнтику Полярной звезды, помещенную в №ㅇ 4, 5, 6 и 7 Русского инвалида 1823 года"

Сын отечества. 4 (1823).

(Оригинал) „С Жуковского и Батюшкова начинается новая школа нашей поэзии." - (Инвалид) „Что разумеет автор под новою школою? Если романтическую, то разве он не знает, что сия последняя имеет по крайней мере столь же многих противников, как и защитников, между нашими литераторами? Далее: думали ли Ж. и Б. быть основателями новой школы. одинаковым ли шли к сему путем и проч." - Все эти вопросы нейдут к делу. Для чего прицеплено замечание о противниках школы романтической? И почему Г. К. вздумал, что я под Ж. и Б. разумею основателей оной? Не полагает ли он, что романизм и романти зм одно и тоже? - Конечно Жуковский принадлежит к школе романтической, но более, как переводчик, нежели как автор; что же до Батюшкова, то В романтическом роде у него написаны только три пьесы: Переход через Рейн. Пленный и Замок в ІІвеции. Впрочем, вероятно что ни Б., ни Ж. не думали быть основателями школы, но к счастию русского языка и гармонии, ими были и суть. 
A. A. Bestuzhev-Martinskii (1797-1837) and K. F. Ryleev (1795-1826) published three volumes of an almanac, Poliamaia zvezda (1823-1825), for each of which Bestuzhev wrote extensive critical essays on the state of Russian literature. In the above text, Bestuzhev quotes the criticism of the reviewer in the journal Russkii invalid in addition to the original statements in his own article, and attempts to clarify his position.

1824 В. Кюхельбекер, „О направленни нашей поэзин, особенно лирической, в последне десятилетие"

мнемозина, XI (1824).

Жуковский и Батюшков на время стали корифеями наших стихотворцев и особенно той школы, которую ныне выдают нам за романтическую. . . .

1833 А. А. Бестужев, „О ромаке Н. Полевого „Клятва при гробе Господнем'” Московский телеграф, LII - LIII, $15-18$ (1833).

И вдруг из этого моря миндального молока возник огнедышаший Державин и взбросил до звезд медь и піамя русского слова... Философ-поэт, он первый положил камень русского романтизма не только по духу, но и по дерзости образов, по новости форм. Прочитав его „Ласточку”, его оду „Бог”, его оду .К счастью”, его „Фелицу”, „Вельможу”, ;Водопад" - и вы назовете их романтическими поэмами . . .

Жуковский . . . плененный чистою мечтательностью Ilиллера и легендами немешкой старины, пересадил романтизм в девственную почву русской словесности.

A. A. Bestuzhev's view of Derzhavin was shared by Gogol who said of the poet, "U nego est' chto-to eshche bolee ispolinskoe i pariashchee, nezheli u Lomonosova. Nedouinevaet um reshit', otkuda vzialsia $v$ nem etot giperbolicheskii razmakh ego rechi. . . Dike, gromadno vse. . ." (Vybrannye mesta iz perepiski s druz iami. 1816). Belinskij held a similarly high opinion of Derzhavin: "s Derzhavina nachinaetsia novyi period russkoi poezii, i kak Lomonosov byl pervym e imenem, tak Derzhavin byl vtorym." Concerning Zhukovskii, the critic said. "Zhukovskii vvel v russkuiu poeziiu romantizm." (Otechestvennye zapiski. XXVIII, 6 [1843]).

1843 А. И. Герцен, „Дилетантизм в науке"

Отечественные записки. 3 (1843).

. . Кто нынче говорит о романтиках, кто занимается ими, кто знает их? Они поняли ужасный холод безучастья и стоят теперь с словами черного проклятия веку на устах - печальные и бледные, видят, как рушатся замки, где обитало их милое воззрение, видят, как новое 
поколение попирает мимоходом эти развалины, как не обращает внимания на них, проливаюших слезы; слышат с содроганием веселую песню жизни современной, которая стала не их песнью, и с скрежетом зубов смотрят на век суетный, занимаюшийся материальными улучшениями, общественными вопросами, наукой, и страшно подчас становится встретить среди кипящей, благоухающей жизни этих мертвецов, укоряюших, озлобленных и не ведаюших, что они умерли! Дай им Бог покой могилы: не хорошо мертвым мешаться с живыми.

Werden sie nicht schaden, So werden sie schrecken. (Although they do not harm, they will frighten us)

The journal Otechestvennye zapiski (founded 1818) was taken over by Kraevskii (18101889 ) in 1839. Kraevskii invited Belinskii to be literary critic. The joumal came to represent the outlook of the Westernizers. Herzen published there his Zapiski odnogo molodogo cheloveka and Part I of Kto vinovat? The early work of Dostoevskii, SaltykovShchedrin, and Turgenev was also published in this joumal.

The two lines in German come from a poem by Goethe, entitled "Drei Oden an meinen Freund Behrisch. Zwote Ode" (published first in 1836), sixth stanza, and refer to snakes and toads as symbols of the evil aspects of nature. 


\title{
DEFINITIONS OF ROMANTICISM
}

\section{5}

\author{
---, „06 опере" \\ Северный вестник, IV (1805).
}

Романяческое есть само по себе чудесное; а все чудесное есть само по себе стихотворческое. Романическое требует свойственного ему выражения: удобнейшее же к тому средство есть соединение музыки с стихотворством.

* Примечание редактора: О сем можно читать Жана Пауля в начальном учснии о превосходном романическом (Vorschule über das Romantische Trefliches [sic])... . . . Романическое для стихотворческого денствия есть утонченная возможность. - а утончение сие не требует смешения с чудесным. - Романическим делается предмет, когда приобретает он вид чудесного. не теряя притом истнны.

1. I. Martynov (1771-1833), the editor of the joumal and a member of the Volinoe obshchestvo liubitelei slovesnosti, nauk $i$ khudozhestv, polemicized against Jean Paul, who had defined romanticism as "das Schone ohne Begrenzung, oder das schöne unendliche.. . . romantisches Dichten. . . ist. . . das Ahnen einer grösseren Zukunft als hienieden Raum hat" Vorschule der Aesthetik. 1804; the title is incorrectly quoted by Martynov). It seems that Jean Paul's definition did not agree with the Russian critic's sense of realism. Martynov's definition demands that the romantic writer poetize life by lending it the appearance of the wondrous or marvelous-yet do so without undue encroachment on the realistic nature of his object. Martynov's note is the first definition of romantic as the distinguishing trait of a new literary trend in Russian.

1821 П. А. Вяземский, [ Письмо А. И. Тургеневу от 25 февраля, 1821 ] Остафьевский архив князей Вяземских, II (Санкт-Петербург, 1899).

И конечно, у Жуковского все душа, и все для души. Но душа, свидетельница настоящих событий, видя эшафоты, которые громоздят для убиения народов, для зарезания свободы, не должна и не может теряться в идеальности Аркадии. Шиллер гремел в пользу притесненных; Байрон, который носится в облаках, спускается на землю, чтобы грянуть негодованием в притеснителей, и краски его романтизма сливаются часто с красками политическими. Делать теперь нечего. Поэту должно искать вдохновения в газетах. Прежде поэты терялись в метафизике; теперь чудесное, сей великий помощник поззии, на земле.

Viazemskii, well known literary critic and poet, a close friend of Pushkin, represented the aspects of romanticism which had been foreshadowed in Andrei Turgenev's speeches of two decades earlier: the demand for a national romantic literature concerning itself with concrete reality and not being afraid of combining literary and political aims. 
Поэт [ романтик ] не знает пределов, пламенное воображение его объемлет всю вселенную, его гений - деспот, распологающий все по своему произволению; вкус его отличен от других; образ выражения особенный, если хотите странный и даже иногда неудобопонятный, ибо самая темнота имеет свою прелесть; в творенки его видна гениальная небрежность, и от сего-то оно не имеет определнного цвета, но сливает в себе, так сказать, все цветы.

Nikolai Tsertelev (died 1869) was primarily an ethnographer who collected Russian and Uk rainian folklore. In his literary views he inclined towards neoclassicism.

1824 П. А. Плетнев, „Письмо к графнне С. И. С. о русских поэтах“ Северные иветы (1825).

І Іоэт умел овладеть нашею душою, потому что он сам глубоко чувствует предмет свой. ІІленяя все наши чувства, он не забывает сердща, которое не может наслаждаться настоящим, не вспоминая прошедшего: а в прошедшем всегда больше для нас прелести, нежели в настояшем. Наконец, он доставляет приятную пищу самому воображению, накидывая покрывало на свой мечтательный мир. Он настраивает все способности души к одному стремлению: из них, как из струн арфы, составляется гармония. Вот в чем заключена тайна романтической поззии! Она основывается на познании поэтического искусства и природы человека. С гаким направлением поэзии Жуковский соединяет высочайшее искусство живописи всех картин природы в которых каждая черта проникнута, освещена его душою.

Peter Pletnev (1792-1865), a romantic poet and critic, later professor of literature, was a close friend of Pushkin, Zhukovskii and other romantic authors. His understanding of romanticism was derived from and applicable to the romantic poetry of Zhukovskii.

1824 П. А. Вяземский, [ Предисловие к „Бахчнсарайскому фонтану”] А. Пушкин, „Бахчнсарайский фонтан” (Санкт-Петербург, 1824).

Легкие намеки, туманные загадки: вот материалы, изготовленные романтическим поэтом, а там читатель делай из них что хочешь. 
Романтический зодчий оставляет на произвол каждому распоряжение и устройство здания - сущего воздушного замка не имеющего ни плана, ни основания.

Viazemskii's essay was of programmatic significance for the romantic movement. The question whether or not a romantic work had a definite plan or structure was frequently discussed by critics and answered in various ways (see below). Already during the first decade of the 19th century Russian critics had defined the loose structure of prose and dramas as "romanicheskii."

\section{4 Ф. Б. Булгарнн, [ Прнмечання к статье Олнна ]}

Литературные листки, 7 (1824).

В диких и разнообразных красотах природы, средь бурь и вьюги, между гор и утесов, в непроходимых дебрях нет связного плана, но есть гармония, это взаимное согласие и соответственность разнородных предк метов . . . И так в поззии, называемой ныне романтическою (которую я назову природною), должно искать, по моему мнению, не плана, но общей гармонии или согласия в целом; не полного очертания характеров, но душевных движений, заимствуюших характер. Если в сочинении происшествия не связаны между собою, - это недостаток природного действия, и поэт накрывает покров на промежутки.

Note that Bulgarin, later known as one of the most conservative writers (linked to the secret police), editor of the journal Severnaia pchela, was close to romantic views in the early 1820's.

1825 Н. М. Рожалин, „Нечто о споре по поводу Онегина" Вестник Европы, 17 (1825).

. . . Сушность романтической поззии состоит в стремлении души $к$ совершенному, ей самой неизвестному, но для нее необходимому стремлении, которое владеет всяким чувством истинных поэтов сего poda.

Pushkin's publication of the first chapter of his novel in verse Evgenii Onegin in 1825 led to a literary polemic. Polevoi published a review in Moskovskii Telegraf where he maintained that " $v$ neopredelennom, neiz"iasnimom sostoianii serdtsa chelovecheskogo zakliuchena i taina, i prichina tak nazyvaemoi romanticheskoi poezii" (No. 5,1825 ). This view was disputed by Venevitinov in Syn otechestva (No. 8, 1825) who wanted to defme romanticism in accordance with the philosophy on which it rested. According to Venevitinov (and Schelling) the poet did not create art out of an "undefined state 
of the heart," but out of a combination of subconscious and conscious strivings arising out of a merging of the principles of freedom and necessity in the artist (or, in Scheiling's terminology, "die Identitaet des Bewussten und Unbewussten im Ich"). N. M. Rozhalin, a close friend of Venevitinov, attempted to use Venevitinov's criteria and provided the above definition which was more in accordance with German, especially Schellingian, romantic philosophy.

-_, „Основное начертанне Эстетикн”

Московский вестник, IV, 92 (1828).

Три рода художественного представления не только определяют основные формы искусства: пластику, музыку и поззию, но и в историческом образовании искусства означают различные его моменты. Объективное или пластическое представление господствует в древнем (Эллинском) искусстве; напротив музыкальное в романтическом; и поелику пластическое и музыкальное представление взаимно дополняются и совершенствуются в пиитическом, как высшем их единстве, так равно и искусство в историческом своем образовании только чрез соединение музыкального романтизма и пластического антицизма может достигнуть совершенства и соделаться поззиею искусства. Всякий особенный род искусственного представления в своей особенности для себя совершенно, но самое искусство, как всеобщее совокупление своих форм, как высшее единство его стихий, может совершенствоваться только гармонией различных родов представления.

The unknown author expressed a commonly held view among romantic writers who distinguished between lower and higher forms of art according to their degree of spinituality. Already Zhukovskii had maintained that "vse drugie khudozhestva ne inoe, kak poeziia v raznykh vidakh," and "iskusstvo-poeziia v raznykh formakh" (V. A. Zhukovskii, Polnoc sobranie sochinenii v 12-i tt. (Sankt-Peterburg, 1902), XI, Pp. 27 and 83).

1832 Н. А. Полевой, „О романах Виктора Гюго, и вообще о новейших романах"

Московский телеграф, XLIII, 1-3 (1832).

. . . Романтизм . . . составлен стремлением духа, решительно противоположным классицизму, стремлением проявить творящую самобытность души человеческой. Вследствие сего,

1-е, романтизм образовывался не только отдельно каждым народом, но даже отдельно каждым великим писателем. Мы не можем сказать, чтобы современный нам романтизм был франиузский, немецкий, английский, испанский: он многообразен, всемирен, всеобъемлющ; сообразуется только с истиной каждой формы; облекается же в формы 
по времени, духу, местности народа, в котором явился тот или другой романтик: содержание его находится в организации времени, общества и писателя. А потому -

2-е, романтизм отвергает все классические условия и формы, смешивает драму с романом, трагедию с комедиею, историю с поззиею, делит творения, как ему угодно, и свободно создает по неизменным законам духа человеческого.

Да не подумает кто-либо, что романтизм есть после сего решительный беспорядок и безначалие. Нет! Противоположный классицизму, отвергнувший его ограниченный обзор и сбросивший цепи его условий, романтизм гораздо правильнее классицизма и требует систему более и строже.

Первое условие его: истина изображений. Вследствие сего романтику потребно глубокое познание человека в мнре действительном, и высокая философия, и всемирность в мире фантазкн.

... Оставив условные формы и выражения классической трагедии, комедии, поэмы, классического романа, он предписывает условий гораздо более: позволяет свободу в родах и видах творений, но требует глубины и полноты в том, что писатель берется изобразить. Отсюда пронсходит то благоговение, с которым романтизм в одно время и оцинаково смотрит на творения простонародные, и на создания II]експира, Байрона, Кальдерона.

. . Вот все основные законы, все главные положения романтизма. Ими, по нашему мнению, определяется и будущая его история.

Polevoi defended the national originality of literature in the spirit of Herder and early romanticism. Note also Polevoi's demand that romantic literature should provide truthful images. His view that every great writer contributed to the formation of romanticism parallel's Stendhal's opinion as expressed in his essay on "Racine and Shakespeare" (1823): "all great writers were true romantics in their own day." The understanding of romantic art as expressing the essence or spirit of a nation was common after Herder and A. Schlegel (cf. also Polevoi's annotation to his essay on p. 108 below).

1833 А. А. Бестужев-Марлинскиһ, „О романе Н. П. Полевого, ,Клятва при гробе Господнем' "

Московский телеграф, $15-18$ (1833).

. . . Мы живем в веке романтизма, сказал я: это во-первых. Мы живем в веке историческом; потом в веке историческом по превосходству. История была всегда, свершалась всегда. Но она ходила сперва неслышно, будто кошка, подкрадывалась невзначай, как тать. Она буянила и 
прежде, разбивала царства, ничтожила народы, бросала героев в прах, выводила в князы из грязи; но народы, после тяжкого похмелья, забывали вчерашние кровавые попойки, и скоро история оборачивалась сказкою. Теперь иное. Теперь история не в одном деле, но и в памяти, в уме, на сердце у народов. Мы ее видим, слышим, осязаем ежеминутно; она проницает в нас всеми чувствами.

Вот ключ двойственного направления современной словесности; романтическо-исторического. Надобно сказать однажды навсегда, что под именем романтизма разумею я стремление бесконечного духа человеческого выразиться в конечных формах. А потому я считаю его ровесником душе человеческой. . . . А потому я думаю, что по духу и сущности есть только две литературы: это литература до христианства и литература со времен христианства. Я назвал бы первую - литературой cyдьбы, вторую - литературой воли. В первой преобладают чувства и вещественные образы; во второй царствует душа, побеждают мысли. Первая - лобное место, где рок - палач, человек - жертва; вторая поле битвы, на коем сражаются страсти с волею, над коим порой мелькает тень руки провидения. Ничтожные случайности дали древней литературе имя классической, а новой имя романтической, столь же справедливо, как новый свет окрестили Америкой, хотя открыл его Коломб.

A. A. Bestuzhev-Marlinskii provides an accurate definition of the historical attitude of the romantic writer. Beginning with Herder, romantic writers developed a demand for historical truthfulness, the ability to understand the past on its own terms and in historic perspective. This same striving is also evident in Pushkin's work, and in Somov's essay on the nature of romantic literature. The juxtaposition of ancient classical art and "modern" Christian art was common in romantic thinking. F. Schlegel said in Athenäum (1800), "I must place the real center, the essence of romantic fantasy, in Shakespeare. From there I seek and find the romantic in the older modern writers; in Shakespeare, Cervantes, Italian poetry, in every age of chivalry, in love, in fairy tales-in all those items from which both the thing itself and the word are derived. Up to the present time, this is the sole means possible to provide an antithesis to the classical poetry of antiquity." In Russia it was Nadezhdin who took this view to its last consequences, maintaining that the term romantic could be applied to European medieval literature only (cf. p. 105). Added to this is the Schellingian understanding of beauty as the infinite represented in the finite.

1834 В. Г. Белинский, „Литературные мечтания" Молва. 38-52 (1834).

. . . Всем известно, как все это сделалось, и потому не хочу распространяться о том, что Шатобриан был крестным отщом, а г-жа Сталь повивальною бабкою юного романтизма во Франции. Скажу только, что этот романтизм был не иное что, как возвращение к естественности, а следственно, самобытности и народности в искусстве, 
предпочтение, оказанное идее над формою, и свержение чуждых и тесных форм древности, которые к произведениям новейшего искусства шли точно так же, как идет к напудренному парику, шитому камзолу и выбритой бороде греческий хитон или римская тога. Отсюда следует что этот так называемый романтизм был очень старая новость, а отнюдь не чадо 19-го века; был, так сказать, народностью нового христианского мира Европы. Германия была искони веков романтическою страною по преимушеству, как по феодальным формам своего правления, так и по идеальному направлению своей умственной деятельности. Реформация убила в ней католицизм, а вместе с ним и классицизм. Эта же самая реформация, хотя несколько в другом виде, развязала руки и Англии: Шекспир был романтик.

Belinskii's view was not original. Similar thoughts had already been advanced by $\mathrm{Na}$ dezhdin (see above and p. 105). 


\section{THE FEUD BETWEEN NEOCLASSICISM AND ROMANTICISM}

1819 Н. А. Цертелев, „Отрывок из писыма к ..."

Благонамеренный. 23-24 (1819).

. . . Как будто непременно закон, читая Письма русского путешественника не развертывают Рассуждения о старом и новом слоге; любя Озерова, ненавидеть Сумарокова, и уважая гекзаметры, предавать проклятию русские меры.

Tsertelev refers to Karamzin's Letters, and Shishkov's well-known treatise on the old and new styk. Ozerov's dramas were praised by P. A. Viazemskii as romantic works (see above, p. 88). Russkie mery referred to the meter of Russian folk poetry which was investigated by Vostokov in his Opyt o russkom stikhoslozhenii (1812), one of the first serious studies of Russian tonal versification. Vostokov attacked the poetics of French classicism and the system of syllabic versification.

$1824--$, , О новых одах Виктора Гуго'а ...” (перевод) Вестник Европы, 13 (1824).

. . . Существенное несходство между тем и другим родом состоит в том. что писатели классические берут свон образщы, свои формы и краски из натуры, из вещественного мира, между тем как романтики ищут свонх в мире идеальном и мечтательном.

... Классики остаются в пределах мира вещественного, между тем как романтики блуждают в идеальном: вот черта пограничная, вот истинное различие между обеими школами.

The author expressed the romantic view that Greek poetry referred to the corporeal, material world, while romantic poetry dealt with spiritual subject matter, emotions, and reflection (cf. Schiller's view of the naile and sentimental attitude, and A. Schlegel's view's in his Berlin Lectures).

1824 П. А. Плетнев, „Орлеанская дева Шиллера”

Труды Вольного общества любителей российской словесности. XXVIII (1824).

Этот взгляд на содержание Орлеанской девы показывает нам, что 
Шиллер не заботился о соблюдания известных трех единств, о которых упоминают в пиитиках, как о необходимых условиях трагедии. Такое нарушение Аристотелевых правил давно сделалось обыкновенным в романтических трагедиях. Оно основывается на высших требованиях драматической поэзии.

The three unities of time, place, and action in drama had been obligatory for classicist authors. Beginning with the late eighteenth century their validity was increasingly doubted. Romantic authors often disregarded the first two unities.

1824 П. А. Вяземскнй, ,Вместо предисловия к Бахчисарайскому фонтану, разговор между издателем и классиком Выбогргской стороны или с Васнльевского острова"

Бахчисарайский фонтан, Соч. А. Пушкина (Москва, 1824).

Кл. Уж вы, кажется, хотите в свою вольницу романтиков завербовать и древних классиков. Того смотри, что и Гомер и Виргилий были романтики.

Изд. Назовите их как хотите; но нет сомнения, что Гомер, Горащий. Эсхил имеют гораздо более сродства и соотношений с главами романтической школы, чем с своими холодными, рабскими последователями. кои силятся быть греками и римлянами задним числом. Неужели Гомер сотворил Илиаду, предугадывая Аристотеля и Лонгина и в угожение какой-то классической совести, еще тогда не вымышленной? Да и позвольте спросить и у себя и у старейшин ваших, определено ли в точности. что такое романтический род и какие имеет он отношения и противоположности с классическим? Признаюсь, по крайней мере, за себя, что не случилось мне отыскать ни в книгах, ни в уме своем, сколько о том не читал, сколько о том ни думал, полного математического, удовлетворительного решения этой задачи. Многие веруют в классический род потому, что так им велено; многие не признают романтического рода потому, что он не имеет законодателей, обязавших в верности безусловной и беспрекословной. На романтизм смотрят как на анархию своевольную, разрушительницу постановлений, освященных древностию и суеверием. . . .

$К л$. Вы так много мне здесь наговорили, что я неуспел кстати сделать отпор вам следующим возражением: доказательством, что в романтической школе нет никакого смысла, может служить то, что и самое название ее не имеет смысла определенного, утвержденного общим условием. Вы сами признались в том, что такое классическая литература, чего она требует . . .

Изд. Потому что условились в определении, а для романтической 
литературы еще не было времени условиться. Начало ее в природе; она есть, она в обращении; но не поступила еще в руки анатомиков. Дайте срок! Придет час, педантство и на ее воздушную одежду положит свое свинцовое клеймо. В котором-нибуды столетии Байрон, Томас Мур, как ныне Анакреон или Овидий, попадутся под резец испытателей и цветы их яркой и свежей поззии потускнеют от кабинетной пыли, от лампадного чада коментаторов, антиквариев, схоластиков; прибавим, если только в будущих столетиях найдутся люди, живущие чужим умом и кои, подобно вампирам, роются в гробах, гложут и жуют мертвых, не забывая при том кусать и живых. . . .

Кл. Позвольте, между тем, заметить вам мимоходом, что ваши отступления совершенно романтические. - Мы начали говорить о Пушкине, от него кинуло нас в древность, а теперь забежали вы и в будущие столетия.

Изд. Виноват! Я и забыл, что для нашего брата-классика такие походы не в силу. Вы держитесь единства времени и места. У вас ум домосед. Извините - я остепенюсь; чего вы от меня желаете? . . .

Viazemskii's title refers to the critics of the romantic school who published in the journal Blagonamerennyi using pseud onyms like "klassik" or "zhitel' Vasil'evskogo ostrova" and "zhitel" Vyborgskoi storony" (two districts of St. Petersburg). M. A. Dmitriev, a minor writer of classicist convictions, answered Viazemskii, and the ensuing polemic continued with three more exchanges of articles. Viazemskii juxtaposed two concepts, imitation and originality, which were considered fundamental for neoclassicism and romanticism respectively.

1825 Н. П., [ Крнтнка ]

Московский телеграф. I (1825).

[Принципы классической зстетики.]

1. Изяшные искусства в самом начале произошли от склонности человека подражать видимым предметам природы. Он услышал пение птичек и начал петь, очертил свою тень на стене и стал рисовать; ударил во что-нибудь звонкое и узнал музыку.

2. А посему все изяшные искусства суть подражание природе. Но как в природе не все изящно, то и надобно подражать природе изящной, т.е. или тому что нам нравится в собственном его виде, или украшенному человеком.

3. В этом руководствует нас вкус, т.е. способность узнавать изящное, или украшать не-изящное и делать его изящным.

[Приншипы новой зстетики и критика старой. ]

1. . . . Boт где заключается начало поззии и музыки - в первых 
выражениях духа человеческого, а не в слепом подражании видимой природе. . . .

2. . . . Эстетики велят подражать изящной природе, но природа одна: в ней многоразличие сливается в единство и обратно разливается в многоразличие. . . .

3. . . . Вкус судит о том, что говорит гений: гений творит, спрашиваяся вкуса - откуда-же возьмут: один материалы для суждекия, другой творическую свою силу? Явное противоречие!

Polevoi, the editor of the journal, outlined classicist principles as stated by Batteux and other theoreticians of literature of the middle of the 18th century in Western Europe and still popular in Russia throughout the 1820's, opposing them to the principles of German romantic philosophy.

1825 А. С. Пушкин, „О поэзни классической и романтической” ГІолное собрание сочинений, XI (Москва, 1937-1959).

. . . Наши критики не согласились еще в ясном разлигии между родами классическим и романтическим. Сбивчивым понятием о сем предмете обязаны мы французским журналистам, которые обыкновенно относят к романтизму все, что им кажется ознаменованным печатью мечтательности и германского идеологизма или основанным на предрассудках и преданиях простонародных: определение самое неточное. Стихотворение может являть все сии признаки. а между тем принадлежать $к$ роду классическому.

Если вместо формы стихотворения будем брать за основание только $\partial y x$, в котором оно писано, то никогда не выпутаемся из определений. Гимн Ж.-Б. Руссо духом своим, конечно, отличается от оды Пиндары, сатира 10венала - от сатиры Горация, Освобожденный Иерусалим - от Энейды, однако же все они принадлежат к роду классическому.

К сему роду должны отнести те стихотворения, коих формы известны были грекам и римлянам или коих они нам оставили; следственно сюда принадлежат; эпопея, поэма дидактическая, трагедия, комедия, ода, сатира, послание, ироида, эклога, элегия, эпиграмма и баснь.

Какие же роды стихотворения должны отнести к поэзии романтической?

Те, которые не были известны древним, и те, в коих прежние формы изменились или заменены другими. 
Pushkin's definition is in consonance with A. Schlegel's concept of classical and romantic as expressed in his Berlin lectures (1801-1804). There he opposed the literature of antiquity to modern poetry, which he said began with the tales and legends of the Middle Ages. Nadezhdin expressed similar views in his dissertation (see below).

1830 Н. И. Надежднн, ---

Вестник Европы. CLXIX, 1 (1830), стр. 1415.

Человек классический был покорный раб влечению животной своей природы; человек романтический был своенравный самовластитель движений своей природы. И там, и здесь упирался он в крайности: или как невольник вещественной необходимости, или как игралище призраков собственного своего воображения. Наш век как будто соединяет или по крайней мере стремится к соединению сих двух крайностей, чрез упрочение. просветление и торжественное, на алтаре истинной мудрости, освящение уз общественных.

Nadezhdin advocated an art which would unite the qualities of classical Greek art with those of medieval romantic art. In the usual romantic manner, he characterized classical art as corporeal (plastic), and romantic (medieval) art as spiritual. Nadezhdin has been claimed as an early precursor of realistic art.

1830 Н. И. Надеждин, „О начале, суцности и судъбах поэзин, романтическоһ называемой"

Атеней. І (1830).

Классическая поэзия воплощала преизбыточествующую полноту духа в творениях, сооруженных по величественному образцу видимого мира; тогда как романтическая поэзия [ т.е. поззия средних веков] - как бы подслушивала внутреннюю гармонию мира незримого, сокрываюшуюся во глубине человеческой души, и отглашала ее в своих гармонических произведениях.

Atenei (1828-1830) was published by M. G. Pavlov. The above excerpt is part of Nadezhdin's dissertation on classicist and romantic poetry. In his understanding, romanticism belonged to medieval times only and was not an acceptable literary form for contemporary writing. 
Март 6. Читаю курс литературы Лагарпа. Какой он раб Аристотеля! Аристотель, Батте, Лагарп, Блер - все эти господа рассуждают о литературе как о каком-то ремесле. Вот так и изготовляются сочинения: трагедии, комедии, речи и проч., как башмаки, платья, мебель. . . . Правило: подражай природе, относится к самой низкой стороне искусства и заключает в себе лишь малейшую часть его. Это то, что мы читаем в пиитиках и риториках в статье: о правдоподобии.

Aristotle was the fundamental authority for the classicist writer. In addition, Russian neo-classicist authors usually referred to Nicolas Boileau (1636-1711) and his $L^{\prime} A r t$ poétique (1674; translated by Trediakovskii, and again by Count Khvostov in 1804), Hugh Blair (1718-1800), professor of rhetoric at Edinburgh, and his Lectures on Rhetoric (1783; translated in 1791 , and several times thereafter), Charles Batteux (17131780) and his Les Beaux Arts réduits a un même principe (1746) and Cours de Belles. Lettres (1765; translated during the first decade of the 19th century), and, finally, to Francois de la Harpe (1739-1803) and his major work, Lycee ou cours de litierature ancienne et modeme (1799-1805; translated 1810-1814).

The above authors continued classicist poetics as outlined by Boileau, but accepted early sentimental influences. This combination of French classicism and moralistic-didactic sentimentalism provided the basis for Russian neoclassicism of the early 19 th century. The works of Batteux, Blair, and LaHarpe had already become widely known at the turn of the century.

1831 - И. И. Панаев, Литературные воспоминания (Москва-Ленннград, 1950), 1832 гл. 2.

В то время (1831-32) в Европе была в самом разгаре война классиков с романтиками. Имена французских сподвижников романтизма - Гюго, Дюма, Барьбе, Сулье, Сю, де Виньи, Балзака - начинали приобретать у нас громкую известность. Гюго своим предисловием $\kappa$,Кромвелю" нанес последний удар классицизму. как выражался Кречетов, приходивший в неистовый энтузиазм от этого предисловия и всегда носившийся с „Кромвелем”. От Вальтер-Скотта я перешел к французским романтикам и читал их с жадностию. Борьба классищизма с романтизмом несколько раздражила мои умственные способности, давно требовавшие какой-нибудь пищи. Я не задумьваясь тотчас же стал под знамена романтизма, представителями которого у нас считал Полевого, Пушкина и его школу, и торжествовал победу романтиков, имея, впрочем, очень слабое понятие о том, что за звери классики. Под словом классищизм я неопределенно разумел вообще все отжившее, старое, обветшалое, и наоборот, под словом романтизм - все живое и новое, $к$ которому начинал чувствовать инстинктивное, непреодолимое влечение. . . . 
... После появления "Notre Dame de Paris" я почти готов был идти на плаху за романтизм. Я узнал о "Notre Dame de Paris" из Московского телеграфа. Вскоре после этого весь читающий пофранцузски Петербург начал кричать о новом генияльном произведении Гюго. ... .

I. I. Panaev (1812-1862), a minor novelist of the 1840 's, left valuable Literatumye vospominaniia describing the literary and cultural life of Russia from the 1820 's to the 1850 's. Panaev mentions the names of French romantic authors, also known in Russia as representative of "la jeune France": Victor Hugo (1802-1885), A. Dumas (pere; 1802-1871), Henri Auguste Barbier (1805-1882), Melchior Frédéric Soulié (1800-1847), and Eugene Sue (1803-1857). lar in Russia.

Alfred de Vigny (1797-1863), romantic poet of the 1820's and 1830's, was popu-

N. Kh. Krechetov (1806?-1886), a medical doctor with literary interests, was a personal friend of Herzen and was close to the literary circles of his time (Belinskii and Stankevich circles). In 1840 he undertook the translation of Shakespeare's plays in prose.

1832 Н. А. Полевой, „О романах Виктора Гюго, и вообще о новейших романах” Московский телеграф. XLIII, 1-3 (1832).

Они хотели математически разделить и самые впечатления и роды изящного. Комедия должна была непременно смешить, трагедия плакать, сатира смеяться. басня заключать в себе нравоучительную мысдь, идиллия описывать пастухов. Вследствие сего определили не только формы каждого рода, но даже предметы, коих должно касаться в каждом роде, даже слова. которые должно употреблять в том или другом роде. Ничего не может быть забавнее разделения слога на высокий, средний и низкий, и определений, что такое высокое, трогательное, страстное, нежное. и когда оно употребляется, где оно прилично, и проч. и проч.

Связав таким образом душу поэта, спутанные в изысканном. ложном обществе своем тысячу мелких обязанностей, приличий, условий. они перенесли ограниченные понятия о нравственных приличиях и в творения изяшные. . . . человек исчез; явились тираны и герои в трагедии. любовники и отщы в комедии, и непременно надобно было тирану умереть. любовнику жениться, герою страдать, а потом торжествовать. отцу говорить сентенции, а шалуну исправляться. Вот пиитика классищизма!

. . . Могут подумать, что мы решительно отвергаем нравственность в изящном. Избави нас Бог! Нет! Мы отвергаем ее только в том близоруком объеме, какого требует классицизм. 
1832 Н. А. Полевой, [ Примечанне к статье „О романах Виктора Гюго, . . ”] Московский телеграф, XLII, 2 (1832), стр. 212-213.

Классическою литературою мы называем вообще литературу древнюю, т.е. греческую и латинскую, и литературу, образованную по ложно понятым основаниям древней литературы, т.е. французскую, перенятую у французов другими народами. В сем последнем, ограниченном смысле мы употребляем в статье нашей слово: классицизм. Романтическою литературою называют собственно народную литературу христианской Европы средних времен; но вообще можно принимать слово романтизм для означения всех литератур востока и севера, а также для означения литературы современной, составившейся из соображения литературы древней классической и литератур северных, южных и восточных.

1833 ---, „Русская литература. Новые книги. Сочинения и переводы в стихах Павла Катеннна"

Московский телеграф, II (1833).

От начала нынешнего столетия существовали у нас в литературе две главные партии, или школы: карамзинистов и славянофилов. Многие люди, даже с дарованием, увлеченные гармоническою, прелестною прозою Карамзина, сделались подражателями его во всем, даже в недостатках, которых у Карамзина было довольно. Аханье, вздохи, словесный филантропизм, однообразие напева, и безотчетное, излишнее употребление слов и оборотов иностранных, были отличительными признаками первой партии. . . .

Славянофилы хотели все обратить к славянскому языку, к древним обычаям и навыкам, и несправедливо почитая современников своих славянами, хотели доказать, что надобно оставить нностранцев, и заимствовать все силы души и слова у родного, как полагали они, источника.

. . . Есть две новые, происшедшие от них, измененные временем партии. Карамзинисты породили новую школу . . . они полагают, что нельзя идти далее его; . . . И школа славянофилов . . . они убежденные что прежде всего надобно быть чистым сыном своего отечества, заимствовав силу и краски у своего народа, и воскрешать старинный, а если можно то и древний быт, древний язык, древние понятия, потому что все это в нынешнем русском мире образовано слишком по иностранному. . . . К этому разряду писателей принадлежат почтенныё имена русской литературы: Грибоедов, Жандр, автор Ижорского [ Кюхельбекер ] , и некоторые другие. К ним принадлежит и г-н Катенин. 
The unknown critic differentiated between romanticism as represented by Zhukovskii, which he linked to Karamzinian sentimentalism, and a more nationalistic and indigenous romantic literature as represented by Katenin, Kiukhel'beker, Viazemskii, Somov and some of the Decembrist poets, which he linked to Shishkov's slavophile views. The different concepts of Zhukovskii and the "mladoarkhaisty" (as the second group has been called by the Soviet critic Iurii Tynianov) led to a literary polemic when Katenin published his adaptation of Bürger's ballad "Lenore" as "Ol'ga" (1816). See also pp. 24 and $35 f$.

1834 В. Г. Белинский, „Литературные мечтання" Moльва, 38-52 (1834).

КАассицизм и романтизм - вот два слова, коими огласился пушкинский период нашей словесности; вот два слова, на кои были написаны книги, рассуждения, журнальные статьи и даже стихотворения, с коими мы засыпали и просыпались, за кои дрались на смерть, о коих спорили до слез и в классах и в гостиных, на площадях и на улицах! Теперь эти два слова сделались как-то пошлыми и смешными; как-то странно и дико встретить их в печатной книге или услышать в разговоре. А давно ли кончилось это тогда и началось это теперь?

1836 Н. В. Гоголь, „Петербургская сцена в 1835/36 годах" Н. В. Гоголь о литературе (Москва, 1952).

Но что такое романтизм? О нем толковали во все окончание первой четверти 19-го столетия и даже сделали его каким-то родом сочинений, так что называли: „зта пиеса романтическая, а это - не романтическая". Ему в противуположность противупоставляли классицизм. Странную несообразность зтого всякий знает. Но что такое то, что называли романтизмом? Это было больше ничего, как стремление подвинуться ближе к нашему обществу, от которого мы были совершенно отдалены подражанием обществу и людям, являвшимся в созданиях писателей древних, - то же стремление, которое имели все государства древнего и нового мира. - Переход к этому стремлению, то есть первые взрывы и попытки производятся обыкновенно людьми отчаянными, дерзкими. какими производятся мятежи в обществах. Они видят несвойственные формы. не соответствуюшие нравам и обычаям правила, и ломятся напролом через все преграды. . . .

. . Много писателей в творениях своих этою романтической смелостью даже изумляли оглушенное новым языком, не имевшее время одуматься общество. 
Compare Gogol's views as expressed here to his evaluation of Pushkin (p. 46), and to Belinskii's evaluation of Gogol (p. 48f). Gogol's understanding also reflects his view of the role of the theatre in society, especially with regard to comedies, of which he had said: "Esli komediia dolzhna byt' kartinoi i zerkalom nashei zhizni, to ona dolzhna otrazit' ee v vsei vernosti."

1840 В. Г. Белинский, „Горе от ума"

Отечественные записки, VIII, 1 (1840).

Стоило присесть на часок да прочесть любую пиитику - и потом рассуждать об искусстве вдоль и поперек. В этих пиитиках основою была идея искусства, как подражания природе, с приличными, впрочем, украшениями вроде мушек, белил и рюмян или вроде подстриженных аллей регулярного сада. Объяснив так премудро и так глубоко значение искусства, приступали к разделению его на роды. Поззия разделилась на лирическую, эпическую, драматическую, дидактическую, описательную, эпистолярную, пастушескую, сатирическую, эпиграмматическую и проч. и проч. , - всего не перечтешь. На чем основывалось это разделение? На внешних признаках, на условной форме, существовавшей отвлеченно от идеи, из которой необходимо должна выходить всякая форма. Что такое, например, драматическая поззия? Вы думаете, что это вопрос важный, для решения которого требуется время, размышление, изучение, наука, о котором можно писать рассуждение, целую книгу? - Ничего не бывало! Не успеете перечесть по пальцам десяти, как вам уже и готов самый точный и самый удовлетворительный ответ. По мнению одних - не слишком бойких, - драматическая поззия есть театральное зрелище, с некоторым подражанием природе, к наставлению и увеселению служащее; позамысловатее и в пиитических хитростях наиболее искушенные - говорят, что драматическая поззия есть выражение настоящего времени, как эпическая - прошедшего, а лирическая - будущего. Коротко и ясно!

Belinskii refers to the numerous manuals of literature which were usually entitled Pravila krasnorechiia, Piitika (poetika), or Ritorika, and listed literary definitions and norms for the benefit of writers and students. Belinskii parodies the style of such works in the participle phrases of the last sentences quoted. 


\section{CRITICISM OF ROMANTIC LITERATURE}

1817 ---, [ Разбор сужденнй де Сталь]

Дух хурналов, 27 (1817).

... [Сторонники романтизма являются] раскольниками литературы, которые предались душою и телом, развратным музам романтического Парнасса.

The accusation of immorabity had been raised earlier by Shishkov against the adherents of Karamzin. It was a frequent accusation and was used again when Pushkin's poem Ruslan $i$ Liudmila appeared in print, leading to the first polemic concerning the new literary school of romantic writing (cf. pp. 113 and 128.)

1819 И. Снядецкий, .О творениях классических и романтических" Вестник Европы. 7.8 (1819).

... [ [Романтический род в поэзии] состоит в жалобных воспоминаниях, в тоске сердиха по минувшем или в возобновлении тех событий, которыми люди занимались во времена рыцарства.

The critic refers to sentimental-romantic poetry as represented by Zhukovskii's romances and the genre of the ballad (see below, p. 112). 
1820 А. Г. Глаголев, „Житель Бутырской слободы. Еще критика" Вестник Европы, CXI, 11 ; and CXII, 16 (1820).

Посмотрите на наш Парнасс: это кладбище, где валяются черепы, кости, полуразвалившиеся гробнишы и кресты могильные; где бродят духи, привидения, мертвешы в саванах и без саванов; где слышны крики вранов, шипение змей, вой волков. . . .

... Не одни баллады имел я в виду, но вообще уклонение многих поэтов от истинного пути, ведущего к совершенству; безмерное подражание не бессмертным красотам классиков, которые у нас вовсе забыты, но блестяшим, нередко ложным прелестям романтизма, если не ошибаюсь, германического.

The journal Vestnik Evropy (originally founded by Karamzin in 1802) was a conservative organ of neoclassicist views in the 1820's.

1820 М. Т. Каченовскнй, ---

Вестник Европы. CXI, 11 (1820).

У нас в такой моде смертность, что даже луч солнечный трепетен и бледен умииает на горе. Ни слова о рыцарях, которые беспрестанно прощаются с красавицами и погибают; ни слова о чащах пенистого вина, о тайном шепоте невидимого, о туманном небосклоне полей. о лазурном крове безоблачного приюта, о пустынной тишине дубрав. о зыбучих берегах, где плачут красные девицы и проч. и проч. 
Трепеща хладною рукой,

Он вопрошает мрак немой. . . .

Вопрошает немой мрак - смело до непонятности, и если допустить сие выражение, то можно будет написать: говорящий мрак, болтающий мрак, болтун мрак; спорящий мрак, мрак, делающий неблагопристойные вопросы и не краснея на них отвечающий: жалкий, пагубный мрак.

$$
\text { С ужасным, пламенным челом. }
$$

То есть с красным, вишневым челом.

A. I. Voeik ov (1779-1839) quoted from Pushkin's Ruslan i Liudmile which had just appeared in print. His criticism points out the novelty of romantic style. The neoclassicist was unwilling to accept this-to him-inaccurate and faulty usage.

1824 П. А. Вяземский, [ Письмо Жуковскому от 13 декабря, 1824 года] Русский архив. I, 2 (1900).

. . Романтизм, как домовой, - многие верят ему: убеждение есть, что он существует, но где его приметы, как обозначить его?

1825 А. С. Пушкин, [ Письмо П. А. Вяземскому ] O suтературе (Москва, 1962), стр. 90-91.

Кстати: я заметил, что все даже и ты имеют у нас самое темное понятие о романтизме. Об этом надобно будет на досуге потолковать, но не теперь; мочи нет, устал.

1825 А. С. Пушкин, [ Письмо А. А. Бестужеву ]

O литературе (Москва, 1962), стр. 102.

Я написал трагедию и ею очень доволен; но страшно в свет выдать робкий вкус наш не стерпит истинного романтизма. Под романтизмом у нас разумеют Ламартина. Сколько я ни читал о романтизме, все не то; даже Кюхельбекер врет.

Alphonse Marie-Louis Prat de Lamartine (1790-1869) was the author of Meditations 
poétiques (1820), based on his love for Mme.'Julie Charles who had died in 1817. His romantic, elegiac verses were famous throughout Europe. Melancholy, disappointment in life, and mysticism were some of the features of his harmonious, melodious, lyrical verse. Concerning Kiukhel'beker see below.

1825 --, „Пнсьмо в Тамбов о новостях русской словесности" Благонамеренный, 7 (1825).

[Период, который начался с Жуковского] был самый несчастный для русской поэзия: славянизмы, галлицизмы, германизмы, мистицизмы, романтизмы, дьяволизмы нападали на нее, голубушку, попеременно. как орды татарские на Россию.

1825 В. Кюхельбекер, „Разбор фон дер Борговых переводов русских стихотворенни"

Сын отечества, CIII, 17 (1825).

В нашем стихотворстве, с одной стороны, слишком много описательного, с другой - слишком мало простоты, слишком много умничанья и поучения. Дадим волю чувству, которого мы лишены, но которого стыдимся. благодаря привитым нам правилам французской поэтики, сплошь составленным из приличий, жеманства и принуждения, - правилам, господствующим еще более в образе мыслей и предрассудках наших светских юношей, нежели даже в книгах учебных. У нас люди светские и поныне раболепствуют перед сими чужеязычными законами, вопреки романтическому лепетанию, коим с некоторого времени бьют в уши встречному и поперечному, ибо теперь, конечно, быть или, по крайней мере, казаться романтиком - обязанность всякого любезника. ${ }^{*}$ Да решатся наши поэты не украшать чувств своих - и чувства вырвутся из души их столь же сильными, нежными, живыми, пламенными, какими вырывались иногда из богатой души Державина!

* Но что же зато и романтизм всех их, пищущих и непишуших? Он обыкновенно останавливается на Ла Мартине, на французском переводе Байрона. на романах Вальтера Скотта. Некоторые только когда-то и как-то заглядывали в мелкие стихотворения Шиллера и даже знают, что Гете написал „Фауста”. Одни смельчаки поговаривают иногда о Шекспире. грозятся прочесть его и охотно бранят Раснна. ибо не в силах ему простить. что лет за пять. буде желали прослыть людыми с умом и со вкусом. буде желали участвовать в светских прениях о словесности. непременно должны были знать .наизусть тирады две-три из его „Федры" или .Гофолии".

V. K. Kiukhel'beker, a "mladoarkhaist," i.e., adherent of modified neoclassicist views, 
reviewed Karl Friedrich von der Borg's translation of Russian poetry, published as Poetische Erzeugnisse der Russen in Riga and Dorpat (1821-1823), and put forward his own view of the necessity of a civic romanticism conscious of its patriotic duties. He criticized von der Borg's preference for poems of the Karamzinian sentimental school. Pushkin said of Kiukhel'beker's articles: “...ego stat'i...napechatannye v 'Mnemozine,' posluzhili osnovaniem vsego, chto skazano bylo protiva romanticheskoi literature $v$ poslednie dva goda" (A. S. Pushkin, Sobranie sochinenii, [Moskva, 1962]). Cf. Kiukhel'beker's trenchant criticism of romanticism, pp. $182 \mathrm{f}$.

1827 Ю- К-В, „Письмо к Лужннцкому старцу о быстрьх успехах русской поэзни"

Дамский журнал, XX (1827).

\author{
Обременительные цепи \\ Упали с рук моих - и вновь \\ Я вижу вас, родные степи, \\ Моя начальная любовь. \\ [Баратынскнй, „Стансы”|
}

Не правда ли, что печальный станс превосходен? Вы может быть, спросите: Из каких цепей вырвался поэт? Где он находится? Читателю нет надобности знать об этом; первые два стиха картинны, новы и, следовательно, чудесны! Далее вы, верно, скажете, что родные степи не могут быть ни начальною, не среднею, ни конечною любовью, равно как любовь не бывает ни степью, ни лугом, не полем. Согласен: да это постаринному; мир романтический есть мир превращений: там небылищы являются в лицах.
Но мне увидеть было слаще
Лес, на покате двух холмов,
И скромный дом в садовой чаще -
Приют младенческих годов.

Чувствуете ли. чувствуете ли, мой почтенный, сладость первого стиха, истинно пиитического? Где найдете вы подобные? Ах, слаще, слаще! Нам не было бы вкуснее теперешнего, аще не следовала бы за тобою в садовой чаще. . . . рифма - тиран.

1828 А. А. Бестужев, [ Письмо к сестре Елене от 10 июня 1828 г.] Полное собрание сочинений Марлинского (Санкт-Петербург, 1847).

. . . Пушкин, бог моды настоящего, весьма мало имеет в себе идеального. т.е. романтического. Все толкуют, все превозносят 
романтизм, и никто не дал себе труда спросить, что это за зверь!

$1828--$, [ Современная русская бнблнографня ]

Московский телеграф, II (1828).

Рецепт составления романтической трагедии из Евгения Онегина:

Общие правила:

1-е. Должно заставить все лица охать, восклицать и бредить громкими словами, чего нет у Пушкина.

2-е. Сцену позволяется переменять до 40 раз.

3-е. Все, что Пушкин говорит от себя, можно заставить говорить действующие лица.

4е. Перенести можно заднее на перед, вставить от себя, исковеркать все, как угодно.

5-е. Включить должно хоры, арии, песни.

1829 П. А. Вяземскнй, „О Московскнх журналах” Вестник Европы (1829).

. . . Наша романтическая поззия есть настоящее лобное место, настоящая торговая площадь. Один поэтический взмах проливает ныне более крови, чем грозная муза Шекспира во всех своих мрачных произведениях: сам Аретин закраснелся бы, глядя на беспутство и наглость, обнажающую себя столь незастенчиво на торжищах литературного нашего мира. . . . . . . - Даже невероятным кажется, чтобы поэма могла иметь поэтический цвет, если она не смочена кровью, - чтобы здание ее было прочно, если оно не сооружено на черепах, подобно древнему Капитолию. Насилия, грабежи, разбои, убийства, братоубийства, отцеубийства, самоубийства, одним словом, все неистовства, до каких только может низвергаться человеческая природа в минуты преступного самозабвения, составляют венец и украшение настоящей поэзии.

Viazemskii refers to the works of the "satanic school" of romantic poetry, and the ultraromantic tales of Bestuzhev-Marlinskii in Russia. His Russkie povesti $i$ rasskazy (1VIII) were collected and published in 1832-34. Pietro Aretino (1492-1556), Italian poet, was the author of obscene writings.

1831 М. Е. Лобанов, „Мненне о духе словесности как иностранной, так и отечественной"
А. С. Пушкин, Собрание сочинений, Vl
(1937-1959), стр. 135.

Ужели жизнь и кровавые леда разбойников, палачей и им подобных, 
наводняюших ныне словесность в повестях, романах, в стихах и прозе, и питающих одно только любопытство, представляются в образец для подражания? Ужели отвратительнейшие зрелица, внушающие не назидательный ужас, а омерзение, возмушающее душу, служат в пользу человечеству? Ужели истощилось необъятное поприще благородного, назидательного, доброго и возвышенного, что обратились к нелепому, отвратному (?), омерзительному и даже ненавистному? . . .

. . . Нынешние, напротив, любят выставлять порок всегда и везде торжествующим и в сердце человеческом обретают только две струны: згоизм и тщеславие. Такой поверхностный взгляд на природу человеческую обличает,конечно, мелкомыслие и вскоре так же будет смешон и приторен, как чопорность и торжественность романов Арно и г-жи Котен. Покаместь он еще нов, и публика, то есть большинство читателей, с непривычки видит в нынешних романистах глубочайших знатоков природы человеческой. Но уже „словесность отчаяния” (как назвал ее Гете), „словесность сатаническая" (как говорит Соувей), словесность гальваническая, каторжная, пуншевая, кровавая, цигарочная и пр., эта словесность, давно уже осужденная высшею критикою, начинает упадать даже и во мнение публики. . . .

Останавливаясь на духе и направлении нашей словесности, всякий просвещенный человек, всякий благомыслящий русский видит: в теориях наук сбивчивость, непроницаемую тьму и хаос несвязних мыслей: в приговорах литературных - совершенную безотчетность, бессовестность, наглость и даже буйство. Приличие, уважение, здравый ум отвергнуты, забыты, уничтожены. Романтизм, слово до сих пор неопределенное. но слово магическое, сделался для многих эгидою совершенной безотчетности и литературного сумасбродства. Критика, сия кроткая наставнища и добросовестная подруга словесности, ныне обратилась в площадное гаерство, в литературное пиратство, в способ добывать себе поживу из кармана слабоумия дерзкими и буйными выходками, нередко даже против мужей государственных, знаменитых и гражданскими и литературными заслугами. Ни сан, ни ум, ни талант, ни лета, ничто не уважается. Ломоносов слывет педантом. Величайший гений, оставивший в достояние России высокую песнь Богу, песнь, которой нет равной ни на одном языке народов вселенной, как бы не сушествует для нашей словесности: он, как бы бесталанный оставлен без внимания. Имя Карамзина, мудреца глубокого, писателя добросовестного, мужа чистого сердием, предано глумлению. . . .

M. E. Lobanov's (1787-1846) essay represented the views of the members of the Russian Academy of Sciences, of which Lobanov, a minor writer of neoclassicist convictions, was a member. Pushkin ridiculed his views (A. S. Pushkin, Sobranie sochinenii, VI [M. 19621, p. 135).

Robert Southey (1774-1843), poet. 
François Thomas de Baculard d'Arnaud (1718-1805), author of many sentimental-romantic novels, was widely translated and read in Russia in the late 18 th century.

Marie (Sophie) Cottin (1770-1807), author of novels such as Elizabeth, or the Exiles of Siberia (1806), Mathilde, and others.

1847 Н. А. Некрасов, „Москва, поэма . . . , Слава о вещем Олеге. . . . Страшный гость ..."

Современник, 4 (1847).

Еще не очень давно в русском государстве, богатом всякими дивами, на каждом шагу попадались юноши, которых в наше время зовут вообше романтиками, - идеальные юноши. Племя было многочисленное и самоцветное, и от него то вели свой род покойные русские позты. Идеальные юноши отличались презрением к земле, на которой, по их словам, было им и тесно и душно, и рвались все туда ... куда? - тайна. которую унесли они с собою; будучи добрыми и смирными малыми и только с виду страшными, - потому что не имели привычки стричь и прочесывать волосы, - они громили проклятиями толпу, презренную, тупую чернь, и в каждом человеке видели врага, с которым будто бы нужно было им бороться (известно, однако ж, из достоверных источников, что никаких битв, кроме карточных, бильярдных и шахматных, они не вели) : изредко покучивая и даже иногда предаваясь пьянству, они считали долгом своим показывать пренебрежение к вещественным благам жизни, и человек, обнаруживштй при них аппетит, навсегда становился в глазах их ничтожным и пошлым. Все они были большие охотники и мастера проклинать судьбу свою, но если верить им, - горячо любили свои страдания и жадно желали их для того чтоб не дать очерстветь дуще; они полагали, что призвание их - страдать. и если невзначай чувствовали себя весело, приходили в отчаяние: за самих себя, за достоинство своих глубоких и высших натур делалось им стыдно. И в книгах и в жизни любили они все необыкновенное, исключительное, - и ничто простое, как бы оно не было поразительно в простоте своей, им не понравилось. Сильно наклонные к дружбе, дружбу понимали они совершенно по-своему: дружба их начиналась с того, что два существа, влекомые друг к другу таинственной симпатией, сперва признавались во взаимной дружбе, потом клялись в верности, как водится, до гроба и за гробом, на словах или даже и на бумаге, для чего у них водились альбомы, памятные книжки, дневники. Затем уже подружившиеся входили во взаимные права свои, права тоже особенные: друг, по их понятиям был такой человек, которому безнаказанно, даже с несомненной надеждой на участие, позволялось всегда и во всякое время пересказывать (переливать в душу) мелкие досады и неудачи свои, огорчения и ропот раздражительного самолюбия. Любовь тоже играла немаловажную роль в их жизни, но любовь особенная, не похожая на обыкновенную. Возвращаясь после дружеских 
попоек обыкновенно утром на другой день, они тем не менее пылали вулканическою страстию к недоступным (непременно недоступным) красавицам. 


\section{PART THREE}

\section{Interpretations II - Poetics}




\section{VII \\ DEFINITIONS OF LITERATURE}

\section{Introduction}

For the classicist, literature had been a means towards an end: to instruct and/or entertain. Early sentimentalism had accepted this view entirely, but shifted the emphasis from the head (reason) to the heart (senses) as the source of literary inspiration. In late sentimental estheticism and early romanticism, literature became the expression of individual emotive reaction and had the aim of affecting the senses in a pleasant manner. The increasing emphasis on emotional and sensual processes led to the acceptance of irrational elements. Preromantic and romantic literature tended to disregard rational thinking as superficial. For them the essence of the world was inaccessible to reason, as it consisted of a kind of spirituality permeating all forms of organic life and revealing itself to man's senses only in a succession of symbols in nature. Speaking of the "realm of invisible forces" in "divine nature," Herder said of this universal spirituality that "dispersed in a thousand and millions of organs, this divine stream of fire is more and more refined to more subtle forms" (Book 5 of Ideen zur Geschichte der Menschheit, translated into Russian in Vestnik Evropy, XVI, 14 [1804], pp. 71 ff.).

Nature appeared as a set of symbols and analogies which only the genius could interpret. Literature was seen in analogy to nature. Baumgarten, the founder of modern esthetics, had already stipulated in his dissertation, Meditationes philosophicae. . (1735), that "nature and the poet produce in a like manner" (Nos. 109-110). Both were expressions of spirit. Professor Galich in St. Petersburg could say that "priroda predstavliaet soboi so storony deiatel'nosti vysochaishee iskusstvo, tak kak so storony bytiiavseob"iatnoe ego izdelie" (A. Galich, Opyt nauki iziashchnogo [SanktPeterburg, 1825], p. 72). For Schelling all nature was a poem.

The concept of nature underwent an evolution in the course of the romantic movement. While initially it had remained confined to picturesque landscapes, it later expanded to include all reality. The organic forms of life in human society became of equal significance and interest to the writer. E. T. A. Hoffmann in Germany and N. V. Gogol' in Russia concentrated on the study of human relationships stressing the demonic, irrational background of life. Literature became the area where the poet could freely recreate the 
universe, where he could approach the ever-receding ideal which was out of reach for him in reality. The search for the ideal-which was often identified with beauty and truth-led the writer to the study of early periods in the history of mankind, accessible to him in myths, folklore, and the primitive life of exotic countries, e.g., North America which Chateaubriand described in his novels. Many romantic writers, among them Gnedich and Del'vig in Russia, glorified ancient Greece, the mother of art, the land of gods and life (A. Musset), where, as A. Schlegel said, life was still wholesome, and man was in harmony with himself and his environment. The increased interest in national mythologies, fairy tales, and folklore in general, stimulated by Herder's writings, led to a growing appreciation of national features in literature. The dissatisfaction with concrete reality (especially in its political aspects) which did not stand up to the exalted dreams of the ideal gave rise to a distinct anti-despotic trend which was prominent in early romantic literature (e.g. Narezhnyi's dramas, and the work of Decembrist poets). One should not overlook the fact that the romantic age coincided with the growth of various utopian-socialist systems which aimed at establishing an ideal social order on earth. Victor Hugo could justifiably say "romanticism and socialism are identical." The esthetic utopia (which sought to effect a change towards a more ideal order via the appeal to man's esthetic sense) of romantic writers, the social utopias of Saint Simon, Fourier, and others, and the unbounded will to achieve liberation from political shackles had a common root in romantic thinking.

Beginning with Rousseau's Confessions, writers tended to identify literature with their personal life. Literature became an account of the poet's most intimate experiences. The poet, being endowed with finer sensibilities than ordinary man, assumed an exalted position in romantic literature. He became a seer whose prophetic vision opened new vistas into the spiritual reality behind visual reality. Being closer to the ideal of beauty, truth, and the absolute, the poet demanded greater rights for himself. Victor Hugo said that the only limits for the poet were those which he set himself in the choice of his goal, that he should not recognize any other force nor any other necessity but that of his idea. The absolute autonomy of the creative individual had been supported by German idealistic philosophy, especially the teachings of Fichte who was popularized in Russia by Professor Schaad at Khar'kov University (1806-1816). A part from sensibility and imagination, the genius depended on inspiration which empowered him to realize the ideal in art, and irony which expressed his superior knowledge of the impossibility of any perfect realization of the ideal in the finite forms of reality (Solger).

Sometimes, as with English Romantic writers, imagination was raised even above inspiration. Coleridge saw in it a creative faculty by which the poet "gains insight into reality, reads nature as a symbol of something behind or within nature not ordinarily perceived" (I. A. Richards, quoted in R. Wellek, Concepts of Criticism [Yale, 1963] , p. 179). Imagination, beauty and 
truth merged in Keat's view of the poet's creative act. The role of creative imagination is emphasized by Venevitinov (voobrazhenie, fantaziia). The young Belinskii defined inspiration (vdokhnovenie) as the "energy" of the soul, a gift of nature which could not be explained further, the source of all creativeness.

The significance of literature for the romantic writer, then, is revealed through the mutual relationship between the concepts of genius, inspiration, imagination, and beauty (as denoting the esthetic ideal) against the background of a my thopoeic, pantheistic concept of nature. 
Натура: Я великое целое - и больше ничего сказать не умею . . Я вся Искусство ... Я составляю все сущее.

Rodzianko, the philosopher of the "Druzheskoe literatumoe obshchestvo" (1801), published poems on philosophical subjects and translations in Utrenniaia zaria (1800-1808), the periodical of students of the University Secondary School ("Blagorodnyi pansion") in Moscow. Zhukovskii began his literary activity there. The above lines illustrate a central concept of romanticism: the mystic unity between nature and art. Nature embodied the creative spiritual essence of the world. Her eternal forms were symbols which only the artist and poet could interpret.

$1805---$, ,.О древней и новой поэзии" Aspopa. I (1805).

Там где предписаны гранишы и самой природе, не оканчиваются еще пределы поззия. Она сама создает миры, вымыслам своим придает жизнь и действие, а изящностью своих картин превосходит красоты света нас окружающего.

The view expressed by the anonymous critic was common at the time. A. F. Merzliakov professed similar views in his lectures of 1812-1813 (printed in Vestnik Evropy). They go back to Baumgarten and his followers in Germany. In his dissertation of 1735, Baumgarten had defined nature as intrinsecum mutotionum in universo principium (the internal principle of all change in the universe) and had pointed out the analogy between nature and the poet. Both were seen as equally creative forces. In Baumgarten's words. "natura et poeta producunt similia" (see paragraphs 49, 109, and 110 of his Medito. tiones philosophicae... [Halle, 1735]).

1812 А. Ф. Мерзляков, „Рассужденне о российкой словесности в нынешнем ее состоянин"

Труды Общества любителей российской словесности при Московском yн-re, 1 (1812).

Образование языка совершается вместе с образованием народа, но оно наипаче видимо в писателях, ибо словесность . . . есть знамение народных успехов и нравственных и политических. 
Merzliakov's treatise was read on the occasion of the first meeting of the "Obshchestvo liubitelei russk oi slovesnosti" in 1812 and expressed the author's fundamental views on literature. Despite a strong neoclassicist bias, Merzliakov was aware of romantic concepts (he had been an adherent of early German romanticism in his youth). His view of the evolution of language as analogous to the growth of a nation reflected Herder's views on language.

1814 Н. И. Гнедич, „Рассужденне о причнах, замедляюших успехи нашей словесности"

Описание торжественного открытия Императорской публичной библиотеки (Санкт-Петербург, 1814).

Без сомнения, что поставлять древнюю словесность образцом во всех отношениях для нашей было бы все равно, что хотеть нашему миру дать образ древнего мира. Различие древних и новых времен неизбежно и различие между поззией сих времен естественно. Но как древняя, так и новая словесность подчинены одному и тому же закону вкуса; и новая, признавая свою соперницу превосходнейшею, должна избирать ее образцом единства, истины, силы и простоты, а особенно в поззия; ибо в поззии греков никто превзойти не может. . . .

Есть также частный вкус народный, зависящий от характера, духа, законов и других местных обстоятельств; он разнообразен, как племена человеческие, но чувствование души нежной и образованной, но изящный вкус, как сама изящность - один, общий, неизменный.

N. I. Gnedich was a member of Shishkov's "Beseda" and simultaneously a friend of Zhukovskii and Batiushkov. His moderate views were well expressed in the above speech. which has been described as a declaration of neoclassicism (N. I. Mordovchenko, Rus. skaia kritika pervoi chetverti XIX veka (M.-L. 1959/. p. 133). Gnedich called upon writers to study Greek literature as a source of inspiration for Russian literature.

1817 К. Н. Батюшков, „Вечер у Кантемнра“

Опыты в стихах и прозе (Москва, 1817).

Полуденные страны были родиною искусств: но сии прелестные дети воображения были часто вытесняемы из родины своей варварством. суеверием, железом завоевателей и, как быстрые волны, разлились по лицу земному. Музыка, живопись и скульптура любят свое древнее отечество, а еше более - многолюдные города, роскошь, нравы изнеженные. Но поэзия свойственна всему человечеству: там где человек дышит воздухом, питается плодами земли, там, где он существует, там же он наслаждается и чувствует добро или зло, любит и ненавидит, укоряет и ласкает, веселится и страдает. Сердще человеческое есть лучший 
источник поззии.

Batiushkov's essay reflects his acquaintance with a work of great influence on the romantic movement, Simonde de Sismondi's De la littérature du midi de l'Europe (1813; partly translated in Syn otechestva, 1823, Nos. 6-8). According to Sismondi, romantic literature began among the Arabs. Among European nations it was the Italians who first wrote in the romantic spirit. Sismondi referred to Tasso, Ariosto, and Dante. These views were shared by $\mathrm{O}$. M. Somov (cf. his essay "O romanticheskoi poezii," Sorevnovatel' prosve. shcheniia i blagotvoreniia [1823]).

1817 К. Н. Батюшков, „Нетто о поэте и поэзнн"

Опыты в стихах и прозе К. Батющкова. I (1817), стр. 81.

Поззия - сей пламень небесный, который менее или более входит в состав души человеческой, сие сочетание воображения, чувствительности, мечтательности, - поззия не редко составляет и муку и услаждение людей, единственно для нее созданных. Вдохновением гения тревожится поэт.

1817 А. С. Пушкин, I Заметки на полях статьн П. А. Вяземского „О жнзни и сочинениях В. А. Озерова"] O ıитературе (Москва, 1962).

Поззия выше нравственности - или по крайней мере совсем иное дело.

1820 М. А. Дмнтриев, „О нравственной целн поэзни" Труды Общества пюбителей российской словесности, XX V II, $17-18$ (1820).

Излишним почитаю занимать внимание ваше размышлением о том, должны ли непременно изящные искусства иметь в виду цель сию [-нравственность]. Некоторые считали ее необходимой. Так и сам знаменитый Тасс, гений, но не теоретик, видел в бессмертной поэме своей ничто иное, как аллегорическую одежду нравственной истины. Другие требовали только от искусств, чтоб они не возбуждали чувствований, противных нравственности, или не расслабляли души. Подобно сему мы видим в Истории изгнание из Лакедемона Стихотворца, прибавившего струну к лире своей и извлекавшего игрой своей слишком нежные и сладострастные звуки. -Наконец, третьи исключают из изящных искусств всякую другую цель, кроме удовольствия. „Искусство говорят новейшие эстетики никогда не рассматривает своего произведения, как средство к достижению какой-либо полезной, или 
нравственной цели. Оно рассматривает его в нем самом." Но самое удовольствие, которого требуют от искусств изяшных, сие удовольствие благородное и возвышенное не есть ли уже цель нравственная? . . .

Я думаю, что единственно от сего местного соединения с природой мы можем достигнуть до поэзии, пронзводящей ту высокость чувства, которая, по моему мнению, составляет всю нравственную цель ее. - Одно глубокое рассматривание природы физической и нравственной, одно философическое наблюдение их взаимных отношений может приучить поэта видеть в каждом неразделимом ее творении, как говорит Ансильон, мысль, облеченную в видимый образ. - И сколь благородна, сколь величественна будет для нас тогда сия природа, когда каждое творение будет для нас не отдельной красотой, но звуком общей гармонии, сия природа, столь немая иногда для души нашей, при всей красоте своей!

M. A. Dmitriev (1796-1866), author of interesting memoirs (Melochi iz zapasa moei pamiati (Moscow, 1869]) and a participant in many literary polemics of the 1820 's, was a newphew of the sentimental poet I. 1. Dmitriev. Himself a minor poet and adherent of neoclassicist views, he at tacked romanticism in general and Pushkin's poems in particular. In the 1840's and 1850's he published polemical articles in the slavophile journal Moskvitianin, in which he attacked the Natural School. The publication of Pushkin's Ruslan i Liudmila in 1820 led to accusations of immorality against the young author.

"Noveishie estetiki"-idealistic and romantic philosophers.

Jean Ancillon (1767-1837) was the author of a treatise on esthetics translated as Esteticheskie rassuzhdeniia in Petersburg in 1813. The same author's Essai sur la différence de la poésie ancienne et de la poesie moderne was used by Somov in his essay on romanticism. (Cf. also pp. 111, 137f.)

1822 П. А. Плетнев, „Рыбаки, идиллия Гнедича"

Труды Вольного общества любителей российской словесности. 28 (1822).

Какая цель каждого произведения искусства? На этот вопрос трудно отвечать вдруг. Первое произведение искусства, каже гся, родилось без цели. Оно было следствием сильного ощушения души, которая не в состоянии была отказать себе в потребности излияния оного. точно так, как мы не можем удержаться от улыбки, когда слушаем что-нибудь истинно забавное. . . . Таким образом и произведения искусств назначены были для возбуждения в других точно такого же удоволствия. какое находили художники, изображая в чувственном виде душевные свои ощущения. . . .

. . . Если сии замечания справедливы, то из них можно вывести следствие, которое определит, какое произведение поэзии, или другого искусства, должно почитать совершенным. Когда оно в состояния совершенно овладеть нашим сердием и направить волю нашу $к$ 
какой-нибудь прекрасной решимости, то каким бы орудием ни образовал его художник и в какую бы страну оно перенесено ни было, везде и всегда будут почитать его совершенным. В общем отношении не одно удивление, но самое живейшее участие оно будет возбуждать во всех истинно образованных людях.

Pletnev's statement on the origin of the arts has to be seen against the background of classicist doctrine which said that the arts originated from the imitation of nature, as well as sensualistic and sentimental concepts (cf. Introduction, II, 1, pp. 62-63).

1823 О. М. Сомов, „О романтической поэзин” Соревнователь просвещения и благотворения. 11 (1823).

. . . Словесность народа есть говорящая картина его нравов, обычаев и образа жизни. В каждом писателе, особливо в стихотворце, как бы невольно пробиваются черты народные. Таким образом почти можно угадать сочинение немца, англичанина или француза, хотя бы даже переводчик скрыл имя автора и утаил, с какого языка переложено сочинение. ... .

Новость поэзия, качества, отличающие ее от стихотворства других племен, состоят не в названиях родов ее, но в духе языка, в способе выражения, в свежести мыслей, в нравах, наклонностях и обычаях народа, в свойствах предметов окружающих и более действуюших на воображение. Докажите мне, что русские не одарены живым, пламенным воображением; уверьте меня, что в нравах наших нет никакой отмены от других народов; что у нас нет, можно сказать, своих добродетелей и пороков, что язык русский весь вылит в формы чужеземные, - и тогда я соглашусь. что у нас нет и не будет своей народной поззик.

O. M. Somov's (1793-1833) essay in three parts, "O romanticheskoi poezii" (published in book form in Moscow in 1823), is an essential document of romantic literature in Russia. Somov defended the notion of an indepedent national Russian literature closely linked to folklore. In his essay he characterized the romantic trend in other national literatures, especially English and German. Several of his characterizations came from Mme de Stael's book De l'Allemagne (1810, published London, 1813).

Somov was also one of the first professional writers in Russia who lived on income derived from his literary activity. In his poetry and prose he often chose themes and motifs from Ukrainian peasant life. In his critical writings he at tacked neoclassicists and defended romantic writers. Somov's insistence on close relationships between literature and society was echoed by many critics. P. A. Viazemskii had been an early proponent of such a view: .литература должна быть выраженисм характера к мнснкй народа..." (..Замсчание на критическое обозрение русской литературы 1820-го года в N. 5 Северного архива 1823-го года", Полное собрание сочинений. 1, СанктПетер6ург, 1878). 
Polevoi had said, "vse mneniia obshchestva dolzhny vyrazhat'sia v literature" (Moskov. skii telegraf, XXXVII/1 [1831], p. 86). N. I. Nadezhdin maintained that "literatura est' pul's vnutrennei zhizni naroda" (Teleskop, XIX [1834], p. 10), and said:

„литература есть глас народа; она не может быть привнлегиею одного класса. одной касты; она есть общий капитал, в котором всякий участвует, всякнй должен участвовать. Если может быть какос-нибудь общенне, какоя-нибудьдружныя. братския союз между разными сословиями, разными классами народа, так это в литературе и через литературу. Основание народного единства есть язык; стало, он должен быть всем понятен, всем доступен" (.Европеизм и народность . . .", Tелескоп, XXXI [1836]).

1824 П. А. Плетнев, „Анакреонтическая ода Державина: Мечта” Труды Вольного общества любителей российской словесности, XXVI, (1824).

Поэзия есть язык сердща. В ней отражаются чувствования, производимые В нас внешними предметами. Характер поззии зависит от характера человека, подобно как иветное стекло, сквозь которое мы смотрим, наводит свой цвет на все предметы.

1825 А. С. Пушкин, „О предисловин г-на Лемонте к переводу басен И. А. Крылова"

Московский телеграф. 17 (1825).

Поэзия бывает исключительно страстью немногих, родившихся поэтами: она объемлет и поглощает все наблюдения, все усилия, все впечатления их жизни. . . .

1827 В. П. Титов, „0 достоннстве поэта" Московский вестник, II, 2 (1827).

. . . Пусть думают невежды, что поззия есть собрание пустых вымыслов.

В сих вымыслах, как в радуге блестяшей, отражается божественный луч истины. Все, говорят нам мудрещы, проистекало от одного всеблагого начала, и все возвратится к нему же; следственно, все благо, изящно, совершенно, - и противоречия мирские суть не иное что, как оптический обман, происходяший от нашей низкой точки зрения. В том же убеждают нас творендя истинных позтов.

. . . Смертный! Ты, который борешься с судьбою и препятствиями в сей долине изгнания, взойди на священный холм поззи, возложи на алтарь ее горести сердечные, как чистую жертву: она укажет тебе солнце тишины, сияющее из твоей небесной отчизны - и ты сойдешь к подвигам 
с силой обновленною. . . .

V. P. Titov (1807-1891), a diplomat and archeologist, was Russian ambassador to Constantinople, and a member of the State Council. In his younger years, he wrote on literary topics in the spirit of German idealistic and romantic philosophy, with which he had become acquainted in the circle of the "liubomudry" in Moscow.

1827 И. Я. Кронеберг, „Мысли об изяшных искусствах” Московский телеграф. III (1827).

10. Поззия не имеет никакой внешней цели. Всякое пиитическое творение есть необходимое произведение природы, и посему и органическое целое, жизнь.

11. Поззия сама по себе совершенна и каждое пронзведение ее есть нечто целое, имеющее душу и тело, существо ограниченное и бесконечное, живое и животворящее . . . есть отдельный органический мир идей и созерцаний.

I. la. Kroneberg (1788-1838), professor and rector of Khar'kov University, wrote widely on subjects derived from Latin literature. A collection of his works appeared in two volumes in 1825-26. In 1830, he published Broshurki in nine installments where he expressed his romantic views. He was a follower of German esthetic concepts.

1828 О. М. Сомов, „Обзор словесности за 1828 год” Атеней. I - IV (1829).

Поэзия также принадлежит к изящным искусствам . . . Изящные искусства все сами для себя цель.

Somov expresses a principle which had been stated by A. Schlegel in his Lectures on Art (Part I, Introduction, 1801-1802).

$1828 \mathrm{X} .$, „O направленин поэзин в наше время" Атеней. 1 - IV (1828).

Недовольный местом в ряду с прочими существами в природе, он [человек ] поставил себя в центре: и природа получила для него значение относительное. Следствием было то, что мы отказали бы даже в названия поэта тому, кто решился бы, по следам Гезиода и Виргилия, 
описать Дни и Работы. Этого не довольно. Занятый самим собою, человек везде хотел видеть только самого себя таким, каким он есть, или каким был. Напрасно некоторые силились восстановить достоинство идеалов в поэзия: век их, кажется, минул невозвратно. Мы требуем теперь человека действительного, с его слабостями, страстями, заблуж:дениями, странностями. Новые потребности указали и на новые источники. Мы начали отыскивать забытые, кинутые предания, памятники народного невежества и легковерия, события времен нестройной гражданственности или вымышленные причудливым младенчествовавшим воображением. Расчетом века охлажденные, не позволяя себе необдуманных порывов души, мы за то с большим жаром стали собирать. как некое сокровище, неясные, но живые, свободные чувствования простой старины, звучашие еще в народных песнях и преданиях . . . .

. . . Произведения поэзии, так названной романтической, основою своею действительно принадлежащие народу, не требовали тех сведений и той степени образованности вкуса, какие необходимо нужны, не только чтобы судить о стихотворении классическом, но даже просто, чтоб понимать оной. Федру Расинову поймут немногие, Руслана читают все. . . .

Мы же теперь имеем занятий стопько разнообразных чисто прозакческих, направление века так материально, что если бы и искусство уметь наслаждаться требовало труда: то, и без того потерявшее много своей значительности, оно совершенно было бы кинуто, в наше полезное время. . . .

Выросшая в веке гибельных переворотов, поззия нашего времени отсвечивает всеми красками, пятнавшими действительную жизнь человека в сем периоде. УМ мятежный и упрямый перенес теперь в беззащитную область поззии ту наклонность к нововведениям, которую с такими пожертвованиями и трудом обуздали на поприще политическом Европь. За нсимением действительнейшего, он тут теперь своенравно осуществляет мечты и грезы свои, порожденные в веке, видевшем во всем крайности. Правкла пиитики, принятые и освященные веками, показались ему теперь ярмом тягостным; он отверг их, как бесполезные, указывая в оправдание на посредственность некоторых талантов, коим правила не помогли возвыситься; позабыв, что правила действуют отрицательно, не дают силы таланту, но сокращают время его младенчества, избавляют от напрасных опытов, представляя собою результаты опытов многолетних, повторенных многократно в разные времена при разных условиях гражданственности, всегда постоянно производивших одинакие действия.

В этой же современной наклонности к нововведениям таится причина и той ничем неуспокойваемой мечтательности, которая, проглянув в Вертере, развернулась в Рене, созрела в поэзии Байрона и 
приметно теперь более или менее в большой части лирических стихотвоений. Заменив мечтами истинные движения души, многие вз позтов закрыли ими ее холод. А как сущность, или простее, содержание сих мечтаний, так резко противоречит всему действительному, то поэты или должны думать, чувствовать и писать одно, а делать другое, или желая согласить мысль с волею, принести мечтам на жертву жизнь действительную со всеми ее приманками выгод и суетности. Вот причина: от чего поэзия многих так холодна и многие поэты, на глаза людей, так безрассудны. . . .

Поэт сосредоточнвает чувствования на самом себе. Та же бесправная самоуверенность, та же гордыня, то же кичение, которые заметны и в наших нравах. Кумир собственного почитания, теперь редкий из поэтов почтет нескромностию много говорить о себе.

Эгонзм пиитический не отстал от современного нравственного. Теперь можно затрудниться искавши какого-нибудь из лирических стихотворений, где бы я не был осью, на коей утверждено движение прочих чувствований. Я решился бы сказать, что современная лирическая поэзия этим ближе к сущности своей, нежели древняя; если бы в наших поэтах столько же было искренности, столько охоты говорить o ceбe.

Verter - Goethe's novel Die Leiden des jungen Werther (1774, translated 1781); RenéChateaubriand's novel (1803, translated 1805).

Arenei (1828-30), edited by M. Pavlov, published neoclassicist poems and plays. Pavlov himself, however, was an adherent of Schelling's view on nature. The journal was one of the first to attack Pushkin. It also polemicized against romantic critics.

1831 А. С. Пушкин, „В газете, Le Furet' напечатано ...” Литературная газета, 32 (1831).

Поэзия, которая по своему высшему, свободному свойству не должна иметь никакой цели, кроме самой себе, кольми паче не должна унижаться до того, чтоб силою слова потрясать вечные истины, на которых основаны счастие и величие человеческое, или преврашать свой божественный нектар в любострастный, воспалительный состав.

1831 Н. И. Надеждин, „Современное направленне просвещення” Teлескоп. I, 1 (1831).

... В настоящие времена творческая деятельность, очевидно, принимает новый характер, неведомый временам бывалым; и искусства 
красуются новою оригинальною физиономиею. Сия физиономия не успела еще выкрепиться резко на всех художественных изделиях нашего века; но ее главное выражение ощутительно везде выливается. Всякое искусственное создание образуется ныне - не по односторонной модели, снимаемой фантазиею с той или другой фазы миросоздания, но по всеобъемлющему идеалу полной жизни. Греко-римская древность работала собственно с натуры; отсюда - высочайше пластический характер всех ее художественных пронзведений; гений средншх веков рождал из головы; и потому все искусственные изделия, ими нам завещанные, отличаются музыкальною мечтательностию. Там списывалась одна видимая природа, во всей роскошной прелести цветущих форм ее; здесь невидимый дух только что вскрывал таинственную глубину свою, волнующуюся неукротимо кипящей жизнию. И то и другое совмещается ныне творческою деятельностию, которая в своих произведениях развивает полную картину бытия, изображая человека в природе и указывая природу в человеке. . . . Отличитевьный характер современного духа образовательных искусств состоит, следовательно, в том, что они не представляют только, но вместе и говорят нам - имеют тон внятный и выразительный. . . . Состояние поззии в наши дни действительно такое. что самый поверхностный взгляд не может не различить в ней волнений новой пробуждающейся жизни. Отсюда - всеобщее восстание против старых поэтических форм, распространяющееся быстро и шумно, под несчастным именем войны романтизма с классицизмом. Новая эпоха настоит действительно для поэзии. Конечно - не мрачное зарево байронизма. обагряющее зловешим сиянием поэтический горизонт наш . должно считаться зарей нового дня, коего рассвет уже празднуется. . . . Истинное направление нового поэтического духа выражается в том постоянном стремлении ко всеобщему уравнению с беспредельною полнотою жизни, которое обнаруживается во всех движениях современной поэзии. Нельзя не видеть, что в настоящее время сия всегдашняя подруга вымыслов вступает в решительное состязание с историей. Она не хочет уступить ей ни в полноте, ни в зерности; и оставляет за собой одно только преимущество - распологать волнующиеся явления действительности в идеальной перспективе. Ее девиз есть истина; ее идеал - вся беспредельная пучина бытия.

See above, p. 105.

1832 И. В. Кнреевский, „Обозренне русской словесности 321831 год” Полное собрание сочинений. II (Москва, 1911).

Наша литература - ребенок, который только начинает чнсто выговаривать. Несмотря на то, ни в какой земле текушая словесность не имеет такой значительности, как в России; и между тем как в других 
государствах литература есть одно из второстепенных выражений образованности, у нас она главнейшее, если не единственное. . . . . . . Литература наша в первой весне: каждый цвет ее пророчит новый плод и обнаруживает новое развитие. Между тем как в других государствах дела государственные, поглощая все умы, служат главным мерилом их просвещения, у нас неусыпные попечения прозорливого правительства избавляют частных людей от необходимости заниматься политикой, и таким образом единственным указателем нашего умственного развития остается литература. Вот почему в России следовать за ходом словесности необходимо не только для литератов, но и для каждого гражданина, желающего иметь какое-нибудь понятие о нарвственном состоянии своего отечества.

I. V. Kireevskii (1806-1856) had been to Germany in 1830 , where he became acquainted with Hegel and Schelling. Soon after his retum in 1832, he began to publish the journal Evropeets which was forbidden by the government during its first year of publication.

1833 В. А. Жуковский, [Пнсьмо И. И. Козлову, 27-го января (8-го февраля) 1833]

Собрание сочинений, IV (Москва-Ленннград, 1960).

Что такое истинная поззия? Откровение в теснейшем смысле. Откровение божественное произошло от Бога к человеку и облагородило здешний свет, прибавив к нему вечность. Откровение поззии происходит в самом человеке и облагораживает здешнюю жизнь в здешних ее пределах.

1834 В. Г. Белинский, „Литературные мечтания" Moлва. 39, 41 (1834).

. . . Литературою называется собрание такого рода художественнословесных произведений, которые суть плод свободного вдохновения и дружных (хотя и не условленных) усилий людей, созданных для искусства, дышащихся для одного его и уничтожающихся вне его, вполне выражающих и воспроизводящих в своих изяшных созданиях дух тоrо народа, среди которого они рождены и воспитаны, жизнию которого дышат, выражающих в свонх творческих произведениях его внутреннюю жизнь до сокровеннейших глубин и биений. . . .

Какое же назначение и какая цель искусства? . . Изобрахать, воспроизводить в слове, в звуке, в чертах и красках идею всеобщей жизни природы: вот единая и вечная тема искусства! Поэтическое одушевление есть отблеск творящей силы пророды. Посему поэт, более 
нежели кто-либо другой, должен изучать природу физическую и духовную, любить ее и сочувствовать ей; более, нежели кто-либо другой, должен быть чист и девствен душою; ибо в ее святилище можно входить только с ногами обнаженными, с руками омовенными, с умом мужа и сердщем младенца, ибо только сии наследят иарствие небесное, ибо толь ко в гармонии ума и чувства заключается высочайшее совершенство человека! . . .

Да - искусство есть выражение великой идеи вселенной в ее бесконечно разнообразных явлениях!

Belinskii expressed the romantic views of Schelling and A. Schlegel in his first major article.

1835 В. Г. Белинския,, „О русской повести и повестях Н. В. Гоголя” Телескоп. XXVI, 7-8 (1835).

Поззия двумя, так сказать, способами объемлет и воспроизводит явления жизни. Эти способы противоположны один другому, хотя ведут к одной цели. Позт или пересоздает жизнь по собственному идеалу, зависящему от образа его воззрения на вещи, от его отношений к миру, к веку и народу, в котором он живет, или воспроизводит ее во всей ее наготе и истине, оставаясь верен всем подробностям, краскам и оттенкам ее действительности. Поэтому поэзию можно разделить на цва, так сказать, огдела - на идеальную и реальую.

. . . Поозия также имеет свои возрасты, которые всегда параллельны возрастам народа. Век поэзии идеальной оканчивается младенческим и юношеским возрастом народа, и тогда искусство должно или переменить свой характер, или умереть. С искусством человечества нашего, новейшего, случилось, как увидим ниже, первое; с искусством человечества древнего случилось последнее, ибо народу, которого поэзия вначале была идеальная, вследствие его идеальной жизни невозможно перейти к поззии реальной. . . .

Простота вымысла в поззии реальной есть один из самых верных признаков истинной поззии, истинного и притом зрелого таланта. . . .

Почти то же самое можно сказать и об оригинальности; как и народность, она есть необходимое условие истинного таланта. . . .

Один из самых отличительных признаков творческой оригинальности или, лучше сказать, самого творчества состоит в этом типизме, если можно так выразиться, который есть гербовая печать автора. У истинного таланта каждое лищо - тип, и каждый тип, для читателя, есть знакомый незнакомеи. 
Note that Belinskii characterized Gogol as a genius and leader of a new literary trend even in this early essay. Belinskii's emphasis on the "real" and the importance of "literary types" led him in due course to formulate his well-known characterization of the "natural school" as the new and adequate literary embodiment of contemporary life. See also pp. $259 f$.

1835 В. К. Кюхельбекер, [ Письмо Н. Г. Глинке 5-го марта 1835] Литературное наследствие, LIX (1954).

Позводены ли поэту картины сладострастные? - Этот вопрос довольно сложен: не забудь, что он разрешается только самою поззиею, а не нравоучением; ибо теория, которая свободное искусство покоряет чему-нибудь постороннему, вместе уничтожает самое искусство. Если картина такова, что смущает нас, что возбуждает в нас скотскую похоть,будь уверен, что тут и самая поэзия улетела: дело поэзия одухотворять вещественную природу, а не подавлять дух веществом. Впрочем, нередко виноват не поэт, а сам читатель: его воображение уже грязно, вот почему оно марает картину поэта. Не смешон ли вопрос: благопристойная ли нагота в Венере Медищейской? И что скажешь о ханже или фавне, который вздумает разбить дивный истукан, дабы он не соблазнял его? Те же нагие истуканы - больщая часть сладострастных картин древних. Гомер, например, говорит о любви Гелены и Александра так же бесстрастно и спокойно, как о щите Ахиллеса; он говорит о ней, потому что того требует его повесть, а не думает любоваться этою картиною, не мешкает на ней, не старается возбудить в слушателе (в его время еще читателей не было) вожделение. Иное дело новые; например, Вијанд, для него сладострастная сцена - находка; он до гадости медлит на самых мелочах, на самых неблагопристойных подробностях. Но повторяю, поэт ли Виланд? - Впрочем, сладострастные картины у древних не советую читать никому, кто к ним не приступит с намерениями и с душой художника. Другая крайность - антипоэтическая - представлять, например, в драме, в романе пицо порочное совершенным дьяволом, променять долг живописца на роль проповедника (говорю роль. ибо для поэта проповедовать - только роль. сверх того роль не в его характере); разумеется, что и тут прэзию убивают наповал, а вместе с нею и истину, потому что человеческих дьяволов нет, не было и никогда не будет. Представляй, художник, припроду, какова она есть; не хвали порочного, но не лишай его и того, что в нем не порок, что в нем прекрасно. Мщение самое адское и страшное чудовище, но в душе мстительной есть знергия, совершенно не зависящая от самой мстительности, хотя мстительность и привита к ней; не лишай же Маргериты де Валоа этой энергии; будь она фурия, но фурия мощная. Нравственность - самое святое дело; но чтобы ты 
сказал о портном, который, не сшив тебе в срок мундира, стал бы говорить тебе: „Николай Григорьевич, не горячитесь! Вспыльчивость порок”. Не так ли, - ты бы отвечал ему: „Предоставь моему духовнику читать мне поучения; твое дело - игла, нитки, ножницы". Тот же портной - поэт: его дело изображать, а не учить. Но польза поззии? Польза, друг мой, великое слово, если только понять, как должно это слово. Часто поэт полезнее всякого проповедника: не могу поверить, чтобы тот легко стал мерзавцем, кто раз полюбил наслаждения, какие дает нам поззия, - разумеется, истинная. Поззия возвышает душу, отвлекает ее от мелких хлопот, попечений, суеты ежедновной жизни, пересе.. ляет ее в мир красоты, покоя, картин и звуков и тем самым омывает, облагораживает ее - вот польза поззии; другой не знаю и не постигаю. Может ли существовать нравоучительная или религиозная поззия? О первой скажу решительно: нет; где учение - там уж нет поэзии. Поззия религиозная совсем не то: если невольное излияние чувтсв, если кто обращается к Богу, говорит об истинах религии, потому что иначе не может, - он, без сомнения, - поэт, и в самом высоком значении этого слова. Но очинить перо, разложить бумагу и сказать самому себе: „Напишу-ка я поэму дидактическую, в которой поражу всех противников католической церкви", - в нравственном отношении очень похвально, но вместе очень и не поэтически; а это-то и сделаr Louis Racine. А этото забывают очень часто наши аристархи.

Venere Meditseiskaia - Medicean Venus; Viland - Ch. M. Wieland (1733-1813); Louis Racine (1692-1763) translated Milton's Paradise Lost into French, and was also the au. thor of Réflexions sur la poésie (1747); Aristarkh - Aristarchus of Samothrace, philologist, symbol of scholarly, welt-meaning criticism. (Cf. also pp. 111, 127f.)

1836 А. С. Пушкин, „Мнение М. Е. Лобанова о духе словесности как иностранной так и отечественной"

Современник, 3 (1836).

Мелочная и ложная теория, утвержденная старинными риторами, будто бы польза есть условие и цель изящной словесности, сама собою уничтожилась. Почувствовали, что цель художества есть идеал, а не нравоучение.

Concerning Lobanov see above, pp. $116 f$. 
1830 's И. И. Панаев, Литературные воспоминавия, гл. 8 (Москва-Ленинтрад, 1950).

Мысль, что искусство должно служить самому себе, что оно составляет отдельный, независимый мир, что чем художник безучастнее в своих произведениях или чем он объективнее, как выражались тогда, тем выше - эта мысль была самою рельефною и господствующею в литературе тридцатых годов. Пушкин развивал ее в своих звучных, гармонических стихах и довел ее до пиющего эгоизма в своем стнхотворения „Позт и чернь”, которое мы декламировали с восторгом и считали чуть ли не лучшим из его лирических стихотворений. Все замечательные литературные деятели тогдашнего времени вслед за Пушкиным и кипевшая около них молодежь были ревностными, горячими зашитниками искусства для искусства.

В последние годы жизни Пушкина, и еше резче после его смерти, Кукольник, принадлежавший также к поклонникам этой теории, проповедывал, как мы видели, еще о том, что истинное искусство не должно обращать внимания на обыденную, современную, пошлую жизнь, что оно должно парить высоко и изображать только героические, исторические и артистические личности.

1840 В. Г. Белинсккй, „Горе от ума" Отечественные записки, VIII/7 (1840).

Поззия есть истина в форме созерцания; ее создания - воплотивияеся идеи, видимые, созерцаемые идеи. Следовательно, поззия есть та же философия, то же мышление, потому что имеет то же содержание абсолютную истину, но только не в форме диалектического развития идеи из самой себя, а в форме непосредственного явления идеи в образе. Поэт мыслит образами; он не доказывает истины, а показывает ее. Но поэзия не имеет цели вне себя - она сама себе цель; следовательно поэтический образ не есть что-нибудь внешнее для поэта, или второстепенное, не есть средство, но есть цель: в противном случае он не был бы символом. Поэту представляются образы, а не идея, которой он из-за образов не видит и которая, когда сочинение готово, доступнее мыслителю, нежели самому творцу. Посему поэт никогда не предпологает себе развить ту или другую идею, никогда не задает себе задачи: без ведома и без воли его возникают в фантазия его образы, и, очарованный их прелестью, он стремится из области идеалов и возможности перенести их в действительность, то есть видимое одному ему сделать видимым для всех. Высочайшая действительность есть истина; а как содержание поззии - истина, то и произведения поззии суть высочайшая 
действительность. Поэт не украшает действительность, не изображает людей, какими они должны быть, но каковы они суть.

The above essay was written soon after the end of Belinskii's Hegelian period (1837. spring 1840) during which he believed in the necessity and rationality of all that existed.

1841 В. Г. Белинский, „Стихотворения М. Лермонтова” Отечественные записки, XIV/2 (1841).

Поэзия есть выражение жизни, или лучше сказать, сама жизнь. Мало этого; в поэзии жизнь более является жизнью, нежели в самой действительности. . . .

Поддобно истине и благу, красота есть сама себе цель и по праву царствует над вседенной только властию своего имени, неотразимым обоянием своего действия на души людей. . . .

Как красота. так и поэзия - выразительница и жрица красоты, сама себе цель и вне себя не имеет никакой цели. Если она возвышает душу человека к небесному, настраивает ее к благим действиям и чистым помыслам, - это уже не цель, а прямое действие, свойство ее сущности; это делается само собою без всякого предначертания со стороны поэта. ПОэт есть живописец, а не философ. Всегдашний предмет его картин и изображений есть ,полное славы творенье” - мир со всею бесконечностью и разнообразием его явлений.

1842- В. Г. Белинский, „Общее значение слова литература”

1844 Сочинения, XII (Москва, 1859-1962).

Под литературою в точном и определенном значении этого слова, должно разуметь сознание народа, исторически выразившееся в словесных произведениях его ума и фантазии, - а так как сознание есть высшее проявление жизни народа, то литература необходимо должна быть его общим достоянием, чем-то таким, что до всех равно касается, всех равно интересует, всем равно доступно. Словом: литература должна быть в отношении к народу вместе и сценою и спектаклем, который на ней разыгривается, а народ в отношении к литературе должен быть публикою, которая не сводит глаз со сцены, созерцая представляемое на ней зрелище. Лучшее для этого средство, повторяю, есть книгопечатание. 
1844 Н. В. Гогољь, „Учебная кннга словесности для русского юношества" 1845 О литературе (Москва, 1952).

Родник поззия есть красота. При виде красоты возбуждается в человеке чувство хвалить ее, песнословить и петь, - хвалить такими словами, чтобы и другой почувствовал красоту им восхваляемого. Поэт только тот, кто более других способен чувствовать красоту творения. Потребность поделиться своими чувствами воспламеняет его и превращает В поэта. (В минуту же такого превращения она освящает самую душу, потому что самое желание заставить и других сочувствовать красоту Божьего творения есть уже желание высокое, восперяющее его и дающее ему силу). Двумя путями передает он другим ошущения: или от себя самого лично, - тогда поззия его лирическая; или выводит других людей и заставляет их действовать в живых примерах, - тогда поэзия его драматическая и повествующая. Третий род - так называемый описательный, или дидактический, - может входить равно в оба рода, но не есть сам по себе путь, которым передает свои впечатления поэт.

The above lines express Gogol's esthetic utopian idea (Zenkovskii) of the fundamental purifying role of beauty. His view is related to German romanticism, especially of the Jena school.

1845 П. А. Плетнев, „Опыт история русской литературы профессора Нвкитенко"

Современник, XXXVIII (1845).

. . . .Литература, по определению r. Никитенка, есть мысль человеческая, возникающая у народа вместе с ним из него духа, жизни, исторических и местных обстоятельств, и посредством слова выражающая свое народно-человеческое развитие под совокупным влиянием верховных и всеобщих идей истинного и изящного". влиянием верховных и всеобщих идей истинного и изящного". ... Итак литература есть духовная жизнь народа, выразившаяся его словом.

. . . Сочинение тогда только становится чисто литературным. когда автор вырахает в нем человеческое свое призвание и неотразимую потребность сосредоточить всего себя в мысли. . . .

A. V. Nikitenko (1804/5?-1877), son of a serf, studied at St. Petersburg University, where he later became a professor of literature (1834). One year earlier he had been appointed censor. In 1836, he defended his doctoral dissertation. " $O$ tvorcheskoi sile $v$ poezii ili poeticheskom genii." In his literary views he was a romantic, in politics a liberal. 
Between 1839 and 1841, he edited the joumal Syn otechestva. In 1845 he published Opyt istorii russkoi literatury. His diary, Moia povest' o samom sebe $i$ chemu svidetel' $v$ zhizni byl (St. Petersburg, 1893), is a valuable literary and cultural document for the 1830 's and 1840's in Russia.

1846 Н. В. Гоголь, „О современнике”

Н. В. Гоголь о литературе (Москва, 1952).

Поззия есть чистая исповедь души, а не порождение искусства или хотения человеческого; поэзия есть правда души, а потому и всем равно может быть доступна.

1847 К. С. Аксаков, „Петербургский сборник, изд. Некрасовым” Московский лит. и учебный сборник на 1847 год (Москва, 1847).

Искусство требует полной преданности себе, и тогда оно облекает избранника дивною силою и высоко становит его над людьми. ІІоговорим здесь о самом впечатлении или создании искусства. После художественного произведения у вас не остается тяжелого, сказали мы. впечатления: если, напр. бедный человек изображен в нем, - в вас не пробуждается даже сострадание: оно пробудится при встрече с бедным человеком в жизни; но это впечатление частное; художник идет глубже. Не возбуждая в вас никакого частного движения, он производит на вас общее впечатление; он действует на начало, на тот общий недостаток, который мешал вам видеть в бедном человеке человека; он истребляет самый зародыш зла, он перерождает вас. - Такова ,ШШинель” Гоголя, способная переродить человека, но не остается после нее тяжелого впечатления: вам не жаль Акакия Акакиевича. Глубокая, примиряющая красота художественного произведения обняла и внесла, между тем, в вашу душу новую жизнь, новое начало; светлее и чище, радостнее стало в вашей груди; впечатление, принятое вами, подействовало на всю душу вашу, и новая великая мысль поселилась в ней. которая на всю вашу жизнь будет иметь влияние. Такое творчество - удел немногих. Для истинного художника необходима полная преданность искусству, полная искренность, полное беспристрастие; только при отсутствии всякой задачи может он решить великую задачу искусства.

K. S. Aksakov (1817-1860), the eldest son of S. T. Aksakov, was a literary critic, journalist. and poet. At Moscow University he was a member of the Stankevich circle and under the strong influence of Hegel's philosophy. Apart from literature he studied philoso- 
phy and history. After graduation (1835) he collaborated in various joumals /Teleskop, Molva, Moskovskii nabliudatel'). Towards the end of the 1830's, Aksakov became one of the slavophile group and a propagandist of national Russian traditions and antiquities. In the 1840's he published several dramatic works, mostly on themes from Russian history. Aksakov also published essays on philological subjects where he pointed out the originality and national individuality of the Russian grammatical system. In his literary articles, he at tacked the Natural School.

Ф. М. Достоевскнй, [ Показання ]

Н. Ф. Бельчиков, Достоевский в процессе Петрашевиев (Москва-Ленинград, 1936), стр. 83-86.

Искусство не нуждается в направлении, . . . искусство само себе целью, . . . автор должен только хлопотать о художественности, а идея придет сама собою; ибо она необходимое условие художественности. . . литература есть одно из выражений жизни народа, есть зеркало общества. С образованием, с шивилизашией являются новые понятия, которые требуют определения, названия - русского, чтоб быть переданными народу; ибо не народ может назвать их в настоящем случае, затем что цивилизация не от него идет, а свыше; - назвать их может только то общество, которое прежде народа приняло цивилизащию, т.е. высший слой общества, класс уже образованный для принятия этих идей. Кто же формулирует новые идеи в такую форму, чтоб народ их понял - кто же, как не литература!

After F. M. Dostoevskii had been arrested for participation in the meetings of the Petrashevskii Circle, where he had read Belinskii's famous letter to Gogol, he was asked by the Investigating Commission to write down his views on the subjects discussed at Petrashevskii's. In the above lines, Dostoevskii polemicized against Belinskii, who, said Dostoevskii, had tried to give literature an unworthy aim, reducing it to the description of journalistic facts ("odnikh gazetnykh faktov") or scandalous events. In Dostoevskii's view it was more important for the writer to concern himself with style and form than with the selection of subject-matter. Dostoevskii expressed similar views in a later article, "Gospodin-ov i vopros ob Iskusstve" (1861). 
THE WRITER AND GENIUS

1801 Ан. И. Тургенев, „О поэзин и о злоупотреблениях оноһ” (речь)

В. М. Истрин, „Из документов архнва братьев Тургеневых", Журнал министерства народного просвещения, XLIV, 3 (1913), стр. 8.

Проходя в мыслях все роды изящных искусств и наук, мы не найдем ничего важнее, ничего священнее поэзии . . . поэты, законодатели смертных, изъяснители таинств божества. . . .

1804 И. И. Мартынов, „О критнке” Северный вестник, 4 (1804).

IІравила суть средства хорошо выполнить то, что критика предписывает дарованию, оставляя ему всю свободу делать еще лучше. Тот хорошо делает, кто, не следуя правилам, делает лучше. Тот худо делает, кто, следуя правилам, делает хуже. Нет ничего обыкновеннее худых сочинений, писанных по правилам, - так, как нет ничего труднее и необыкновеннее хороших сочинений, писанных не по правилам. Говорят, что несколько строк гения полезнее для дарования, нежели целые курсы учения, с трудом писанные профессорами. И это вероятно, когда хотят воспламенить и возвысить душу. Но самые лучшие образщы освешают один только предмет тогда, когда сии ученые правила освещают целый путь. Из сего следует: первое, что не должно иметь к сим рабским правилам ни рабского почтения, ни гордого презрения; второе, что нет всеобщей критики, кроме той, когда все общество, более или менее просвещенное, смотря по месту и времени, но всегда почтенное, состоящее из лучших умов своего народа, соединит, наконец, вместе все голоса пля составления всеобщего мнения; третие, что хороший критик красноречия и поэзия должен быть сам красноречив и поэт.

Severyni vestnik expressed the views of the members of the "Vol'noe obshchestvo" (Free Society). Martynov's lines illustrate the moderate views of the Society. While accepting many tenets of the early romantic trend, they spoke out against stylistic abuses of both sentimental and preromantic literature. 
1805 Н. П. Бруснлов, --

Журнал российской словесности, 12 (1805).

. . . Писатель, дурной или хороший, есть человек общественный - он трудится не для одного человека: сочинение его принадлежит целому обществу.

The journal Zhurnal rossiiskoi slovesnosti (1805), edited by N. P. Brusilov (died 1849), was one of the organs of the Free Society. Brusilov's emphasis on the social obligations of writers characterized the thinking of the majority of the Society's members. 
Личей, 1, 1(1806).

. . . Обязанности писателя не в том только состоят, чтобы писать много и писать обо всем; но надобно стараться произведениями свонмн посеять какие-либо полезные истины нравственности. Возбудить в нас страсти легче, нежели нас просветить, но самое возбуждение страстей должно направлять к неминуемой пользе. Итак, тот, кто желает с пользою возбудить страсти в человеке, желает проложить кратчайший путь $K$ добродетели.

Истинные писатели суть те, котррые весь свой дар ума употребили в пользу своего отечества и для народной нравственности; правительству остается только ободрять деятельность таковых умов.

A. A. Pisarev (1780-1848), a curator of Moscow University, and later military governor of Warsaw, was a literary critic and member of the Free Society in his youth. He expresses neoclassicist views in his essays.

Личей. 11 (1806), стр. 35.

... В „Историческом обозрении художеств”, которое также читанось на заседании .,Вольного общества” 18 ноября 1805 г., говорится:

„Всякий художник, сверх совершенного знания своего искусства . . . обязан знать все, относящееся до отечества своего. Пусть кисть художника избирает в истории яркие предметы, которые могут служить прнмерами для сограждан его. Пусть резец художника изображает черты великих мужей, бывших во славу его отечества."

The journal Litsei (1806) was edited by 1. I. Manynov, a member of the Free Society. The views expressed here correspond to a trend which became increasingly evident in literary discussions of the first decade of the 19 th century. Both the preromantic young poet Andrei Turgenev and the sentimentalist Karamzin (the latter particularly after 1800), as well as conservative authors of Admiral Shishkov's convictions, stressed the desire to rely in literature more on subjects taken from national history.

1808 В. А. Жуковскй, „Письмо из уезда к издателю” Вестник Европы, XXXVIII, 1 (1808).

. . . Любить истинное и прекрасное, наслаждаясь ими, уметь их изображать, стремиться к ним самому и силою красноречия увлекать за собою 
других - вот благородное назначение писателя! Счастлив, когда провидение, наградивши его талантом, одарило и сердцем, способным любить высокое, чуждым привязанностей унизительных.

. . . Наш друг, посвящая себя трудам писателя, должен забыть приятную рассеяность большого светского круга: желание в нем блистать противно спокойным занятиям автора.

. . . Но можно ли, ты скажешь, совершенно отделиться от людей, заключить себя в четырех стенах, жить с одними безмолвными идеями, с одними воздушными созданиями воображения? Дает ли одиночество счастие? Кто ж награждает писателя, когда не люди, и где же слава его, когда не в обществе? - Мой друг! Я не хочу запереть приятеля нашего в келью, но говорю ему: чем менее круг, тем связи привлекательнее и сильнее. Иши людей, которые способнее других ценить твои работы; их суд есть голос современников и приговор потомства.

. . . Кто неспособен опереться на благородные достоннства; кому не довольно утешительной хвалы немногих, но просвешенных судей, . . . для кого все равно производить хорошее или худое, лишь бы похитить успех. тот должен отказаться от мнимых своих прав на славу! Он будет торжествовать, благодаря невежеству и легкомыслию, но торжество его не оставит и признака следов: никогда не достигнет он благородной цели писателя пользы, распространения идей. благодетельных для человечества, наслаждений, совершенствуюших душу.

For two years (1808-1809) Zhukovskii was editor of the prestigious Vestnik Eiropy. During this time he occupied himself with literary theory, including German esthetics. In his views. he is still close to sentimentalism, which demanded that the writer exert a positive moral influence on his readers. thereby contributing to the general harmony of society.

В. А. Жуковский, „Писатель в обществе” Вестник Квропы. 22 (1808).

ПІрибавим: Писатель имеет в обществе существенное преимущество пред людьми более светскими; он может порядочнее и лучше мыслить. От умственной работы, которой посвящена большая часть его дня, приучается он обдумывать те предметы, которые светский человек только что замечает; будучи весьма часто один с собою, он имеет гораздо более времени возобновлять воспоминанием то, что видел глазами; привычка приводить в порядок, предлагать в связи и выражать с точностию свои мысли дает понятиям его особенную ясность, определенность и полноту. которых никогда не могут иметь понятия человека, исключительно занимающегося светом: последний по причине разнообразия предметов, мелькающих мимо него с чрезвычайною быстротою, 
принужден, так сказать, ловить их на лету и устремлять на них внимание свое только мимоходом. Уединение делает писателя глубокомысленным; в обществе приучается он размышлять быстро и, наконец, занмствует в нем искусства украшать легкими и приятными выражениями самые глубокие свои мысли. Конечно, всякий писатель от образа своей жизни, более или менее ограниченного, должен быть несколько от других отличен - но разве отличие и странность одно и то же?

Отчего же, спросите вы, большая часть писателей не имеет никакого успеха в свете, неловки в обращении и вообще менее уважаемы; нежели их книги? От трех причин, из которых две - общие писателю со всеми: от страстной привязанности к своему искусству, от самолюбия, от ограниченности состояния.

Всякая страсть наполняя человеческую душу предметом единственно ей любезным, отделяет ее от всего внешнего и сему предмету чуждого. . . .

. . . Он обитает в особенном, ему одному знакомом или им самим сотворенном мире; существа идеальные всегдашние его собеседники; он ограничен в самых естественных своих потребностях: все то, что ему нужно, находится в нем самом, в его идеях, в мечтах его воспламененного воображения.

Другою причиною неуспехов тисателя в свете полагаю чрезмерность самолюбия, свойственного ему со всеми другими людьми, но вообще в писателях более ослепленного, приметного и смешного. . . .

. . . Самолюбие автора гораздо заметнее и смешнее самолюбия прелестников, остряков и им подобных, тонкого, искусного и более скрытого. Они всегда в свете, следовательно и самые странности их менее разительны; их суетная гордость прикрыта маскою простоты; они только изредка себе изменяют. Напротив, писатель, будучи весьма часто один и, следственно, сохранив более собственного в своем характере и обращении, отличнее от других и в смешном и в странном.

Третья причина случайная: ограниченность состояния. Она может мешать писателю наравне с другими пользоваться выгодами и удовлетворять требованиям светской жизни. Лишенный способов играть одинакую роль с людьми, одаренными избытком, и будучи не в состоянии доставлять им те удовольствия, которых сам от них получает, писателькоторому вместе с дарованием досталась в удел и бедность - принужден являться в общество изредка, и то не иначе, как зритель, не имеющий никакой тесной связи с действующими на сцене его лицами. Сия необходимость быть простым зрителем препятствует ему приобрести искусство обхождения,познакомиться с приличиями, узнать все нужные обряды светской жизни. . . .

. . . Писатель с дарованием истинным щедро вознагражден природою за все обиды пристрастной фортуны. Имея в виду одни благородные 
занятия мыслящего, богатого чувством и любовию ко всему прекрасному человека, он будет в тишине души довольствоваться скромным своим уделом, своею деятельностию в малом круге; он будет довольствоваться распространением своего ума и ограничением своего сердца. Утрату разнообразия в удовольствиях заменит он продолжвтельностию их и полнотою. Для него человеческое общество разделено будет на два круга: один обширный, В которьй он входит взредка с твердою решимостию быть просто зрителем спокойным, холодным, без всяких честолюбивых требований и надежд, без всякого соперничества с людьми, желающими в нем торжествовать, равнодушный к собственным свонм неуспехам, желающий единственно приобретения некоторых новых понятий, некоторой образованности, необходимой его таланту; он будет не замечен, это верно; зато не будет и странен: ибо в свете находят странными одни усилия самолюбивых, безполезно желающих отличить себя пред другими каким-нибудь превосходством; тихая скромность будет его украшением. Вся деятельность его в сем круге ограничится единственно тем влиянием, которое он.не может иметь на него посредством своего таланта. Другой круг - тесный, есть тот, в котором он счастлив, любим и любит, где он имеет успех без всякого усилия, не прибегая к утонченному и коварному искусству; там его уединение, где он наслаждается жизнию, в труде безмятежном и полез. ном, где он беседует с самим собою, где он высокими чувствами и мыслями совершенствует душу свою, где он вверяет бумаге сокровище собственных мыслей и чувств для пользы современников, быть может и для пользы потомков; там его друзья, соединенные с ним одинакою деятельностию, сходством жребия, склонностей, дарований; их строгая разборчивость его образует, их благодетельное соревнование животворит в нем творческий пламень, в их искренней похвале его воздаяние и слава; там, наконец, его семейство. Для писателя, более нежели для кого-нибудь, необходимы семейственные связи; привязанный к одному месту своими упражнениями, он должен около себя находить те удовольствия, которые природа сделала необходимыми для души человеческой; в уединенном жилище своем, после продолжительного умственного труда, он должен слышать трогательный голос свонх любезных; он должен в кругу их отдыхать, в кругу их находить новые силы для новой работы; не имея вдали ничего, достойного искания, он должен вблизи, около себя, соединить все драгоценнейшее для его сердца; вселенная, со всеми ее радостями, должна быть заключена в той мирной обители, где он мыслит и где он любит.

Zhukovskii propounds sentimental-romantic views of the writer who withdraws from society and is rewarded by nature with a rich reflective and imaginative life. In Zhukovskii's view, the writer who is not distracted by society and lives in loneliness develops a more 
sensitive attitude. His peculiarities and idiosyncracies, arising from his isolated way of life and his manners, not molded by constant social intercourse, will become more prominent. What might be considered a negative result becomes a positive feature of the writer's lifehe does not need society, as he lives in his own world of fiction and ideals. His withdrawal to this world is furthered by his introverted character and gives rise to an overdeveloped egocentric emotional attitude. Such views are mainly rooted in 18 th century sentimentalism, but include significant features of early romanticism, especially with regard to the opposition of society and the poet's solitary existence, and his withdrawal to an ideal world of imagination. Zhukovskii's demand of a small circle of friends and a well ordered family life is again quite in the spirit of sentimentalism.

1812 А. Ф. Мерзляков, „О генни, об изученни поэта, о высоком и прекрасном” Вестник Европы. VI (1812).

Талант обладает искусством и дает образ; гений изобретает и дает существо; заслуга одного в тщательной разборчивости. - другого в вымыслах; один велик в подробностях. другой - в составе целого. Человек с талантом пишет обыкновенное, всеми повторяемое, но гораздо более украшенное и с лучшим вкусом расположенное. Человек с гением. нарротив того, имеет свой собственный способ видеть, слышать и чувствовать ... О. Обыкновенные люди часто смотрят и не видят: гений видит чрезвычайно быстро, не смотря.

The distinction between talent and genius was a common one in romantic writing (cf. Pushkin's "Mozart and Salieri"). A welt-known definition of the genius had been provided by Lavater in his essay on Goethe translated in 1808 /Vestnik Evropy. XLII, 21, pp. 44. 48). Russians could read there:

..гения есть цслос, столь обширнос. что умственныя взор наш не в силах обня вдруг разнообразных частең его . . . гнев его . . . приводит в трепет безумиј. которы осмелился воспламенить его. и никогда уже не подумает он вооружиться против ьеликого человека. им оскорбленного. . . Не знаю никого столь снизчодительного и в то же время столь ужасного. как Гете."

1813 А. Ф. Мерзляков, „Об изящном, или о выборе в подражания” Вестник Европы. 111 (1813).

. . . Поэт посредством слова подражает предметам и их действиям. описывает столь живо и неоживленные, что вы их видите пред собою. как будто в самой существенности. Поэма его представ.яет маленькую вселенную, а сам кажется твориом своего мира. Но во всех случаях только подражает и не более. 
... Прнводит нас в приятное, любезное полохение; та же прнрода, которая не говорит нкчего сердиу или возмущает нас неприятными впечатлениями, противна намеренням поэта и долхска быть изгнена из поззии.

See above, p. 144. In the last paragraph above, Merzliakov repeats a principle of neoclassiciam, announced by Batteux as the imitation of beautiful nature (cf. Ch. Batteux, Les beaux arts réduits'alun même principe [Paris, 1746] , Pt. I, Chapter 1, paragraph XII).

1814 И. М. Муравьев-Апостол, „Писыма из Москвы в Нижнй Новгород” Сын отечества, 1, 7 (1814).

Везде, только не у нас, есть сословия писателей, к которым люди готовятся и в оные вступают, точно так, как мы вступаем в военную или гражданскую службу: у нас того вовсе нет: мы все пишем, так сказать, ad libitum, мы dillettanti, а не virtuosi; точно то в сравненив с писателями по состоянию, что в музыке охотник к настоящему музы:канту. ...

Ivan Muraviev-Apostol (1765-1851), writer and diplomat, served in Hamburg and Madrid. In 1811, he was elected a member of the Russian Academy of Sciences. As an active member of Shishkov's "Beseda," he published his works, mostly translations, in the proceedings, Chteniia) of the Society. His Pis'ma iz Moskvy v Nizhnii-Novgorod (Syn otecheswo. XVII, 40,1814) expressed the views of the more nationalistically inclined romantic writers who later participated in the Decembrist uprising. Three of his sons were involved in the rebellion. Cf. pp. $147 \mathrm{ff}$.

1815 К. Н. Батюшков, „Две аллегорин”

Сочинения, III (Санкт-Петербург, 1886).

- Напишите. сказал бы я живописиу (который до сих пор не написал ничего оригинального, а только рабски подражал Рафаелю, но который может изобретать ибо имеет ум, сердще и воображение), напишите мне гения и фортуну, обрезывающую у него крылья.

Художник: А, я вас помню! (немного подумав). Вы хотите изобразить жестокую победу несчастия над талантом, гения живописи. . . .

Я: Я не назначаю именно какого генвя; от вас зависит выбор гения поэзии, гения войны, гения философни, науки или художества, какого вам угодного; только гення пламенного, пылкого, наполненного гордости и себяпознания, которого крылья неутомимы, которого взор орлиный проницает, объемлет прнроду, ему подчиненную, которого сердие утопает в сладострастии чнстейшем и не изъяснимом для 
простого смертного, при одном помышления о добродетели, при одном именовании славы и бессмертия.

Худохник: (С радостию взяв мел, подбегает к грунтованному холсту). Я вас понимаю, очень понимаю ...

Я: Я уверен, что художник меня поймет, когда дело идет о славе.

Худохник: (Взяв меня за руку и краснея при кахдом слове).

Вы не поверите, как я люблю славу: стыдно признаться; но вы хотите (чертит мелом абрис фигуры), вы хотите . . .

Я: . . . напитавши воображение идеалом величия во всех родах, пишите смело: ваш гений будет гений, а не фигура академическая. Теперь вообразите себе, что он борется с враждебным роком; запутайте его ноги в сетях несчастия, брошенных коварною рукою фортуны; пусть слепая и жестокая богиня обрезывает у него крылья с таким же хладнокровием, как Лахезиса прерывает нить жизни героя или лучшего из смертных - Сократа или Моро, Лас-Казаса или Еропкина, благодетеля Москвы. . . .

Я: Слава отдает свои крьлья гению; любовь зажигает его пламенник; гений прощает изумленной фортуне и в лучах торжественного сияния воспаряет медленно к небу.

Batiushkov opposes his own romantic concept of the genius to the neoclassicist and academic image. Lachesis - one of the three goddesses of fate in Greek mythology. Moro Jean Michel Moreau (1741-1814), French painter and print-maker, taught for two years at the Academy of Fine Arts in St. Petersburg. Bartolome de las Casas (1474-1566), Spanish prelate, accompanied Columbus on his second voyage, and distinguished himself by his humane conduct towards Indians. Petr D. Eropkin was a general and senator who suppressed a popular uprising in Moscow in 1771 at the time of the plague.

1815 К. Н. Батюшков, „Нечто о поэте и поэзии”

Опыты в стихах и прозе Константина Батюшкова, I

(Санкт-Петербург, 1817).

. . . Некто сравнивал душу поэта в минуту вдохновения с растопленным в горниле металлом: в сильном пламени он долго остается в первобытном положении, долго недвижим; не раскаленный - рдеется, закипает и клокочет; снятый с огня - в одну минуту успокаивается и упадает. Вот прекрасное изображение позта, которого вся жизнь должна приготовлять несколько плодотворных минут: все предметы, все чувства. все зримое и незримое должно распалять его душу и медленно приближать сии ясные минуты деятельности, в которые столь легко изображать всю историю наших впечатлений, чувств и страстей. . . .

... Надобно, чтобы вся жизнь, все тайные помышления, все пристрастия клонились к одному предмету, и сей предмет должен быпь 
искусство. Поззия, осмелюсь сказать, требует всего человека.

Я желаю (пускай находят странным мое желание!), чтобы поэту предписали особенный образ жизни, пинтическую биэтику: одним словом, чтобы сделали науку из жизни стихотворца. Эта была наука для многих едва ли не полезнее всех Аристотелевых правил, по которым научаемся избегать ошибок, но как творить изяшное никогда не научимся!

Первое правило сей науки должно быть: живи, как пишешъ, и пиши, как живешъ. . . .

... Эпическому стихотворцу надобно все испытать - обе фортуны. Подобно Тассу, любить и страдать всем сердщем; подобно Камоэнсу, сражать за отечество, обтекать все страны, вопрошать все памятники искусства, всю природу, которая говорит всегда красноречиво и внятно уму возвышенному, обогащенному опытами, воспоминаниями. Одним словом, надобно, забыв все ничтожные выгоды жизни и самолюбия, пожертвовать всем - славе; и тогда только погрузиться (не с дерзостию кичливого ума, но с решимостью человека, носящего в груди своей внутреннее сознание собственной силы), тогда погрузиться в бурное и пространное море эпопеи. . .

Toss - Torquato Tasso (1544-1595), mainly known as the author of the epic poem Gerusalemme liberate (1581); Kamoens - Luis de Camoes (1524-1580), author of the epic poem Os Lusiades (1572). Both writers were considered examples of "modern" (romantic) European literature. Batiushkov, at the threshold of the romantic age in Russia, already gave an exact description of the romantic genius. Note as typical features the romanticizing of life and the identification of the poet's life with his poetry.

1817 П. А. Вяземский, „О жнзнн и сочннениях В. А. Озерова”

В. А. Озеров, Сочинения, I (Санкт-Петербург, 1817).

. . . Обязанность его и всякого писателя есть согревать любовию $к$ добродетели и воспалять ненавистию к пороку, а не заботиться о жребии и приговоре провидения.

1821 Н. И. Гнедич, „Речь о поэзин и поэтах, пронзнесенная в июое 1821 года" Соревнователь просвещения и благотворения, XV (1821).

... Если соединяющие силы рук своих то врагов покоя общественного достойны хвалы граждан и венцов славы, то люди, соединяющие силы разумы, сии безоружные воины, ведушие брань с пороками, предрассудками. невежеством, со всеми невидимыми, но опаснейшими врагами 
общества человеческого, имеют не менее прав на его признательность. Но когда еще люди сии как труды, так и плоды трудов свокх приносят в жертву общую, когда они упражняют силы свои не для выгод, какие могут приобресть, но для добра, какое могут сделать, кто откажет в уважении сим добродетелям гражданским? И в то же время, видя самый источник сих добродетелей - науки и просвещение, кто не признает божественности их вдохновения, святости их наслаждений? Чистые и невинные, они принадлежат всем возрастам, всем годинам жизни; свободные, они сообщаются с каждым, простирающим к ним руку; благородные, они ведут вас к наслаждениям совершеннейшим, к наслаждениям добродетели.

. . . Как в древности пламенник игр священных быстро переходил из рук в руки, переходит теперь от народа к народу пламенник искусств и познаний. В такое время перо писателя может быть в руках его оружием более могущественным, более действительным, нежели меч в руке воина. Я не о тех говорю писателях, людях, впрочем, с дарованием. которые, усилием и навыком приобретая известную легкость в слоге, заставляют читать себя и слушать. Такой писатель есть почти каждый образованный гражданин в странах просвещенных, они обыкновенно составляют так называемую литературу света, - и, ласкатели его, уголники всех прихотей моды и духа времени, они рабы мнения. . . .

. . . Писатель своими мнениями действует на мнение общества. и чем он богаче дарованием, тем последствия неизбежнее. Мнение есть властитель мира. Да будет же перо в руках писателья то, что скипетр в руках царя: тверд, благороден, величествен! Перо пишет, что начертается на сердщах современников и потомства. Им писатель сражается с невежеством наглым, с пороком могущим и сильных земли призывает из безмолвных гробов на суд потомства. Чтобы владеть с честию пером, должно иметь более мужества, нежели владеть мечом. Но если писатель благородное оружие свое преклоняет перед врагами своими. если он унижает его, чтобы ласкать могуществу, или если прелестью цветов покрывает разврат и пороки, если вместо огня благотворного он возжигает в душах разрушительный пожар и пищу сердец чувствительных превращает в яд, - перо его . . . или оружие убийства! Чтобы памяти своей не обременить сими грозными упреками, писатель не должен отделять любви к славе своей от любви к благу общему. - Да будет же первою страстию, нас одушевляющею, вдохновением нашего ума и сердца - любовь к человечеству, сия любовь незнакомая, непостижимая сердщам необразованным, сие чувство небесное, которое даже одним желанием сделать счастливыми нас окружаюших, делает и нас самих более счастливыми.

. . . Наконец, писатель да любит более всего язык свой. Могущественнейшая связь человеческих обществ, узел, который сопрягается 
с нашими вравами, с нашими обычаями, с нашими сладостнейшими воспоминаниями, есть язык отцов наших! И величайшее уничижение народа есть то, когда язык его пренебрегают для дыка чуждого. Да вопиет противу зла сего каждый, ревнуюший просвещению, да гремит неумолкно и поззией и красноречием! Пусть он в желчь негодования омачивает перо и всем могуществом слова защищает язык свой, как свои права, законы, свободу, свое счастие, свою собственную славу!

. . . Чтобы имя писателя переживало века и народы, да посвящает он перо свое предметам, которые составляют неизменную пищу ума и сердца во всех веках, у всех народов! Пусть он пишет не для человека, но для человечества.

. . . Пробудить, вдохнуть, воспламенить страсти благородные, чувства высокие, любовь к вере и отечеству, к истине и добродетели вог что нужно в такое время, когда благороднейшими свойствами души жертвуют эгоизму, или так называемому свету ума, когда холодный ум сей опустошает сердще, а низость духа подавляет в нем все, что возвышает бытие человека. В такое время нужнее чрезмерить величие человека, нежели унижать его, лучше подражать тем ваятелям древности, которые произведениям свонм дали образы благороднейшие и величество, превосходящее природу земную, чем поззию уподоблять Цирщее, превратившей в животных спутников Одиссея.

Plamennik igr sviashchennykh - torch of the Olympic games of ancient Greece. Gnedich was close to the "mladoarkhaisty" (see above p. 3). He assigned to the poet the task of enlightening the nation and formulating public opinion. The poet's pen is compared to the scepter of the Tsars. Like Katenin he insisted on the preservation of the character of the national language. Compare his views to those of Andrei Turgenev (p. 144). Tsirtseia - Circe. Odissei - Odysseus.

1823 О. М. Сомов, „О романтической поэзин”

Соревнователь просвещения и благотворения, 11 (1823).

. . . Весь мир видимый и мечтательный есть собственность поэта, он везде собирает щветы, везде пьет жизнь и силу, и в тайнственном своем вдохновении являет мысленным взорам свет незримый и дивный.

See above, p. 129. 
1824 П. А. Вяземский, [ Пнсьмо Бестужеву от 20 января, 1824 года ]

Русская старина (ноябрь, 1888), стр. 324.

Достоинство писателя у нас упадает с каждым днем, и если малому числу избранных не поддерживать его, то литература сделается какоюто казенною службою, полищейским штампом или и того хуже - какимто отделением министерства просвещения. Независимость - вот власть, которой должны мы служить верою и правдою. Без нее нет писателю спасения: и ум, и сердие его, и чернила - все без нее заплеснеет.

1825 В. К. Кюхельбекер, „Отрьвок из путешествия по полуденной Франция” мнемозина. IV (1825).

Поэт некоторым образом перестает быть человеком, для него уже нет земного счастья. Он постигнул высшее сладострастие, и наслаждения мира никогда не заменят ему порывов вдохновения. . . Он блуждает по земле, как изгнанник, ищет и никогда не находит успокоения. . . .

... [[Іоэт] учит времена и народы и разгадывает тайны провидения, он точно есть полубог без слабостей, без пороков, без всего земного. - Но самая способность к вдохновениям предполагает пламенную душу, ибо только пламя может воспыл ать к небу! . . . Поэт предпочитает страдание вялому, мертвому спокойствию. . . .

. . . Вернейший признак души поэтической - страсть к высокому и прекрасному: для холодного, для вялого, для сердца испорченного необходимы правила, как цепь для злой собаки, а хлыст для ленивой лошади: но поэт действует по вдохновению и столь же мало гордится своею жизнию, как своими творениями, ибо чувствует, что все ему данное есть дар свыше, а он только бренный сосуд той божественной силы. которая обновляет и возрождает человечество!

V. K. Kiukhel'beker (1797-1846), Decembrist poet, was a "mladoarkhaist" in Iu. Tynianov's definition (sce above, pp. 3, 39).

1825 А. А. Бестужев, „ Взгляд на русскую словесность в течение 1824 и начале 1825 годов"

Полярная звезда на 1825 год (Санкт-Петербург, 1825).

Гомер, нищенствуя. пел свои бессмертные песни; Џекспир под лубочным 
навесом возвеличил трагедию; Мольер из платы смешил толпу; Торквато из сумашедшего дома шагнул в Капитолий; даже Вольтер лучшую свою поэму написал углем на стенах Бастилии. Гении всех веков и народов, я вызываю вас! Я вижу в бледности изможденных гонением или недостатком лиц ваших-рассвет бессмертия! Скорбь есть зародыш мыслей, уединение - их горнило. Порох на воздухе дает только вспышки, но сжатый в железе он рвется выстрелом и движет и рушит громады. .. . И в этом отношении к свету мы находимся в самом благоприятном случае. Уважение или, по крайней мере, внимание к уму, которое ставило у нас богатство и породу на одну с ним доску, наконец, к радости сих последних исчезло. Богатство и связи безраздельно захватили все внимание толпы, - но тут в проигрыше, конечно, не таланты! Иногда корыстные ласки меценатов балуют перо автора; иногда не достает собственной решимости вырваться из бисерных сетей света - но теперь свет с презрением отверг его дары или допускает в свой круг не иначе, как с условием носить на себе клеймо подобного, отрадного ему ничтожества; скрывать искру божества, как пятно, стыдиться доблести, как порока!! Уединение зовет его, душа просит природы; богатое нечерпанное лоно старины и мощного свежего языка перед ним расступается: вот стихия поэта, вот колыбель гения!

A. A. Bestuzhev-Marlinskii (1797-1837) wrote reviews for his almanac Poliarmaia zvezda (1823, 1824, 1825; edited together with Ryleev), the legal publication of Decembrist writers. Bestuzhev's views, that the evolution of literature led from an age of geniuses to an age of mediocrity, and that Russia had literary criticism yet not literature of its own, were disputed by Pushkin (see his Polnoe sobranie sochinenii, 13 [1937], pp. 177-80.).

1825 К. Ф. Рылеев, [ Писымо А. С. Пушкину от первой половины июня, 1825 ] ІІолнос собрание сочинений (Москва-Ленинтрад, 1934).

. . . Сила душевная слабеет при дворах и гений чахнет; все дело добрьх правительств состоит в том, чтобы не стеснять гения. Пусть он пронзводит свободно все, что внушает ему вдохновение. Тогда не надобно ни пенсий, ни орденов, ни ключей камергерских; тогда он не будет без денег, следовательно без пропитания; он тогда будет обеспечен. Гений же немного и требует в жизни. Тогда потерпят, быть может, только одни самозваншы-гения. Прощай гений. 
1827 А. И. Кронеберг, „Мысли об изяшных искусствах" Московский телеграф. III (1827).

14. Гений, не только образ, но часть творческого духа природы, и действуя сообразно ее законам, имеет в искусстве свою автономию. 15. Великому поэту известны все народы, все времена, все состояния; природа для него открыта, и он видит не только ее сокровища, но постигает и душу всякого явления. . . .

See above, p. 131.

1827 В. П. Титов, „О достоннстве поэта” Московский вестник, II, 7 (1827).

Поэт не создан жить во внешности; все силы души его соединены в его всеобъемлющей фантазии, которая в минуты вдохновения рисует ему все, что есть великого, утешительного в судьбе и назначении человека. Добродетельный всегда забывает самого себя, думая о благе ближнего. В высокие минуты поэт свободнее его переносится во все времена и во всех людей и повсюду открывает ту гармонию, которой верит его любящее сердце. Вот почему поззия назидательна: превратности житейские могут истребить в нас ту любовь к человечеству и к жизни, без коей нельзя быть добродетельным; поэзия, представляя жизнь в истинном. лучшем ее виде, мирит с нею.

See above, p. 131.

1829 Д. В. Прутиков (А. М. Полторацкй), „Новый жявописец общества н литературы"

Московский телеграф, VI (1829).

Гений, ныне модное слово, и люди бегут на добычу сего имени; . . . все хотят иметь какую-то печать особенности, и, как-бы то ни было и чем-бы то ни было, не походить на других. . . .

Мне часто попадаются 20-ти летние юноши, на выбор все гении: обо всем чудесном и необыкновенном судят; все чрезвычайно знают: будущее пророчат, как календари погоду; прошедших и настоящих обстоятельств в подробности ведать не хотят, как дело обычайное, а к делу они неспособны, потому что это было бы вещь обыкновенная. Они утверждают, что участь гения вновь созидать, не следуя опытом начертанной стезе и соблюдению порядка. 
1830 И. В. Киреевский, „Обозренне русской словесности 1829 года” Деннича - альманах на 1830 год (Москва, 1830).

... Как мысль зовет звук, так народ ищет поэта. Ему необходим наперсник, который бы сердцем отгадывал его внутренную жизнь, а в восторженных песнях вел дневник развитию его господствующего направления. Поэт для настоящего, что историк для прошедшего: проводник народного самопознания.

1830 П. А. Катенин, „Размышленкя и разборы. О поэзия вообще” Литературная газета, 4 (16 янв., 1830).

Чем ближе поэт новый, наш, обрабатывая предмет древний или чуждый, подойдет к свойству, быту и краске избранного им места, времени, народа и лица, тем превосходнее будет его произведение; чем менее сумеет он туда перенести себя и читателя, тем опыт его будет хуже и неудачнее.

Предписывать поэту выбор предметов, несправедливо и вредно; кто может по чужим внушениям действовать так свободно, горячо и успешно, как по собственным?

One of the achievements of romantic literature was a historistic at titude, the need to see events and people in historical perspective. This was accomplished by the use of local color and the study of historical documents.

1832 Н. А. Полевой, „О романах Виктора Гюго, и вообще о новейших романах"

Московский телеграф. XLIII, 1-3 (1832).

. . Собственно изящное не есть истина, не есть и благо: красота есть прямой симбол и настоящая цель оного. Истина и благо совершенно слиты с ним; но если их будем иметь преимущественно в виду, мы ошибемся, точно так же, как жертвуя ими единственно для красоты. Поэт, художник, будучи гражданином, будучи философом, должен быть собственно поэтом, собственно художником; но он не будет ни тем, ни другим, если откажется в произведениях своих от прав философа и гражданина.

В произведениях его путеводитель - восторг, коим руководствует в мире фантазии ум и сердце. Мир представляется художнику загадкою; его творение есть решение сей загадки. Он действует притом как художник; не решает как философ, не судит как гражданин того или другого 
общества, но воссоздает свои идеи в образах, взятых из природы и человека, следственно, необходимо впадает в идею истины и блага, если только изящное у него совершенно.

Polevoi echoes romantic views of literature. Schelling had said of beatuy, "finally, the idea which unites all other ideas, the idea of beauty.... I am now convinced that the highest act of reason, the one by which reason encompasses all ideas, is an esthetic act, and that truth and goodness ("Gute") are related only in beauty" (H. Zeltner, Schelling [Stuttgart, 1954], p. 65). Similarly, Polevoi reflects the romantic view of nature as a symbol and a mysterium accessible to the poet alone.

1832 --, „Современная библиография. Стихотворения Дениса Давыдова” Московский телеграф, IV (1832).

Вся жизнь Давыдова есть поззия, начиная от благословения, данного ему Суворовым, и до последних походов. Он тратил вдохновения свои не на писанье, а на действия. Стихи его суть немногие лучи того света. коим озарена его жизнь . . . поэтическая душа находит во всем поззию. . . . Он во всем видел идеальное ...

D. V. Davydov (1784-1839) began to write in the early years of the 19th century. As his poetry was first published only in 1832 he is usually associated with that time, and his innovative activity of the first two decades of the 19th century is overlooked. Davydov created the image of the partisan and poet-dilettante. Poetry and life merged in the image of the daredevil hussar who lived for the glories of the battlefield, love, wine, and cards. He was the incarnation of the strong individual of preromantic literature who lived by his passions, disregarding the limits of conventional morality.

1835 В. Г. Белинский, „О стихотворениях г. Баратынского” Tелескоп. XXVII, 9 (1835).

. . . В числе необхојцимых условий, составляющих истинного поэта, должна непременно быть современность. Поэт больше, нежели ктонибудь, должен быть сыном своего времени.

1836 Н. В. Гоголь, [Пнсьмо М. П. Погоднну ] Полное собрание сочинений, XI (Москва, 1937-52).

... Грустно, когда видишь, в каком еще жалком состоянии находится у нас писатель. Все против него, и нет никакой сколько-нибудь равносильной стороны за него. „Он зажигатель! Он бунтовщик!” И кто же говорит? Это говорят люди государственные, люди выслужившиеся, 
опытные люди, которые должны бы иметь на сколько-нибудь ума, чтоб понять дело в настоящем виде, люди, которые считаются образованными и которых свет, по крайней мере русский свет, называет образованными.

Gogol refers to a letter of May 31, 1836 by F. F. Vigel' (a highly placed official in the Department of Foreign Affairs) to Zagoskin, in which Vigel' said: "Ia znaiu g. avtora 'Revizora', -eto iunaia Rossiia, vo vsei ee naglosti $i$ tsinizme."

1837 П. А. Плетнев, „История поэзни, сочннение Шевьрева” Отчет Академии Наук о шестом присуждении Демидовских премий (Санкт-Петербург, 1837).

Жизнь, природа дают богатое вещество поэту; но идея художественная, идея бессмертная есть собственность бессмертной души его. Бесконечная душа поэта принимает в себя жизнь и природу, несушие к нему все свои сокровища, все врсменные дары свон: он силою мысли творческой претворяет их в стройные и вечные создания; ибо он один посвящен В тайны гармонии жизни и слышит ее чутким слухом. Он один из смертных существ способен в нестройную массу, в мертвое вещество, вдохнуть мысль, душу живу.

Stepan Shevyrev (1806-1866), poet, critic, and historian of literature (whose book is reviewed here by Pletnev), was a member of the Moscow "liubomudry" circle where he studied Schelling's romantic philosophy. Together with Titov and Mel'gunov he translated Tieck's and Wackenroder's Herzensergiessungen eines kunstliebenden Klosterbruders (1797) as $O b$ iskusstve $i$ khudozhnikakh (1826). In 1834 he began to lecture at Moscow University on the theory and history of literature. His lectures were published as /storiia poezii (1835). In the 1840 's he turned to slavophile views.

1838 А. И. Герцен, „Литература и общество” ПІолное собрание сочинений (АН СССР, 1954), стр. 326.

. . . Великий художник не может быть несовременен. Одной посредственности предоставлено право независимости от духа времени. . . .

1841 В. Г. Белинский, „Стихотворения М. Лермонтова” Отечественные записки. XIV, 2 (1841).

Поэт - благороднейший сосуд духа, избранный любимеи небес, тайник природы, золова арфа чувств и ощущений, орган мировой жизни. Еще 
дитя, он уже сильнее других, сознает свое родство с вселенной, свою кровную связь с нею; юноша - он уже переводит на понятный язык немую речь, ее таинственный лепет . . .

Когда он говорит - он царь, он властелин вселенной, поверенный таин природы, прозираюший в таинства неба и земли, природы и духа человеческого, только ему одному открытые; но когда он находится В обыкновенном земном расположении - он человек, но человек, который может быть ничтожным, но никогда не может быть низким, который чаще других может падать, но который так же быстро восстает, как падает, - который всегда готов отозваться на голос, несушийся к нему от его родины - неба.

.. . Чем выше позт, тем больше принадлежит он обществу, среди которого родился, тем теснее связано развитие, направление и даже характер его таланта с историческим развитием общества. . . .

Свободный, как ветер, он повинуется только внутреннему своему призванию, таинственному голосу движущего им Бога, а на крик тупой черни. которая бы стала приставаґ к нему, в своей дикой слепоте:

Нет, если ты небес избранник, Свой дар, божественный посланник, Во благо нам употребляй: ....

Поэт не подражает природе, но соперничествует с нею, - и его создания исходят из того же источника. и тем же самым процессом. как и все явления природы, с тою только разницею, что на стороне процесса его творчества есть еще и сознание которого лишена природа и ее деятельность. Вся природа со всеми ее явлениями есть плод вдохновенного порыва духа - из идеальной области возможного перейти в реальную область действительного, стать фактом, чтоб потом, в разумнейшем своем явлении - человеке, взглянуть на себя, как на нечто особое. сознать себя. И всякое произведение искусства есть плод вдохновенного усилия художника - вывести наружу, осушествить вовще внутренний мир своих бесплотных идеалов.

See above p. 125.

Назначение гения - проводить новую, свежую струю в поток жизни человечества и народов. Но брошенная гением идея принималась бы слишком медленно, если 6 не подхватывали ее на лету таланты и 
дарования, роль и назначение которых - быть посредниками между гениями и толпою.

1844 В. Г. Белинский, „Сочннення Александра Пушкина” (ствтъя V) Отечественные записки, XXXII, 2 (1844).

Всякий истинный поэт, на какой бы ступени художественного достоинства ни стоял, а тем более всякий великий поэт, никогда и ничего не выдумывает, но облекает в живые формы общечеловеческое. . . .

. . . Чем выше поэт, то есть чем общечеловечественнее содержание его поззии, тем проще его создания, так что чнтатель удивляется, как ему самому не вошло в голову создать что-нибудь подобное: ведь это так просто и легко! . . .

Наше время преклонит колени только перед художником, которого жизнь есть лучший комментарий на его творения, а творения - лучшее оправдание его жизни.

1846 ---ин, ,Непризнанный поэт”

Первое апреля (Санкт-Петербург, 1846), стр. 74.

Поэт, непременно должен смотреть бурею: лицо его всегда пасмурно, мрачно; следы страстей, самых пламенных, утрат самых горестных, видны на нем. При этом во всем непременно должно быть нечто рыдающее, вопиющее, чтоб всякий видел, что наш поэт непростой, что он жил, страдал, дрался в кровопролигной битве с железным роком, и потому носит на себе все следы этой несчастной битвы!

1848 В. Г. Белинский, „Взгляд на русскую литературу 1847 года" Современник, 1-2 (1848).

Личность поэта не есть что-нибудь безусловное, особо стоящее, вне всяких влияний извне. Поэт прежде всего - человек, потом гражданин своей земли, сын своего времени. Дух народа и времени на него не могут действовать менее, чем на других. . . . Вот отчего теперь ис ключительно эстетическая критика, которая хочет иметь дело только с поэтом и с произведением, не обращая внимания на место и время, где и когда писал поэт, на обстоятельства, подготовившие его к поэтическому поприщу и имевшие влияние на его поэтическую деятельность, потеряла теперь всякий кредит, сделалась невозможною. Говорят: дух партий, сектантизм вредят таланту, портят его произведения. Правда! И потому-то он должен быть органом не той или другой партии или 
секты, осужденной, может быть, на эфемерное существование, обреченной исчезнуть без следа, но сокровенной думы всего общества, его может быть, еще не ясного самому ему стремления. Другимн словами: поэт должен выражать не частное и случайное, но общее и необходимое, которое дает колорит и смысл всей его эпохе.

Belinskii defended a view of the writer which he had already outlined in his introduction to an edition of Kol'tsov's poetry (St. Petersburg, 1846), where he had ascribed the poet's greatness to his ability to assimilate national Russian features. Belinskii was opposed by Valerian Maikov who maintained that a poet had to overcome national traits in order to become of univereal significance. See alsu pp. $58 \mathrm{f}$. 
1806 А. А. Писарев, „Рассуждение о словесности”

Лицей, I, I (1806).

Упадок словесности означает слабость воображения, слабость воображения означает уменьшение способностей ума; с уменьшением способностей ума уменьшают все способности души и сердща и человек пресмыкается! . . .

A. A. Pisarev (1780-1848), a member of the Free Society, expresses views which were close to neoclassicism. See above, p. 146.

1809 В. А. Жуковскнй, „О басне и баснях Крылова"

Вестник Европь. 9 (1809).

Что называют дарованием поэта? Воображение, представляющее предметы живо и с привлекательной стороны, способность изображать сии предметы для других приличными им красками и так, чтобы они представлялись им с такою же ясностию, с какою и нам самим представляются; способность (в особенности необходимая баснолисцу) рассказывать просто, приятно, без принуждения, но рассказывать языком стихотворным, то есть украшая без всякой натяжки простой рассказ выражениями высокими, поэтическими вымыслами, картинами и разнообразя его смелыми оборотами.

Zhukovskii retained many sentimental features, as can be seen from this and the following text. His views hark back to the 18 th century when imagination had been conceived as the power of visualization or the inventive power of the poet (D. Hume), "a combination of innate sensibility, the power of association, and the faculty of conception" (Walter J. Bates, From Classicism to Romanticism [Cambridge, Mass., 1946], p. 113). In contrast to these sentimental and neoclassicist views, the romantic writer emphasized imagination as the central creative force in the poet which allowed him to read the symbols of nature (for example, Shelley defined poetry as "the expression of the imagination" in his Defense of Poetry). 
. . . Что нужды стихотворцу, действующему на одно воображение, если рассудок, по строгом понятии, найдет веши совсем не такими, какими представляются они воображению? Что нужды ему до противуречий логических, если они не ощутительны для чувства? . . . И если стихотворец умел прикрыть противоречне; дал вымыслу наружность справедливого искусством, нигде не отступил от главного предположения, на котором основал он свой вымысел, - то он в совершенстве исполнил предписанное законами его искусства; и если во многом погрешил он противу здравой логики, то, без сомнения, не сделал ни одной ошибки как стихотворец.

... Чего требует от поэта его искусство? Чтобы он не оскорблял непосредственно чувства морального, чтобы он не противоречил морально-изящному, которое почитается одним из главных источников красоты стихотворческой, - но существенною моральною красотою занимается он столь же мало, как и сушественною логическою истиною. . . .

The conflict between "heart" and "head" (or emotion and reason) was a central point in disputes between 18 th century classicists and sentimentalists. The sentimentalist, basing himself on sensualist philosophy from Locke to Hume, gave more weight to the heart, i.e., sensual cognition. Note again Zhukovskii's sentimental views, which demand that literature be in consonance with moral values. Zhukovskii expresses the attitude of late sentimentalism (or sentimental estheticism), according to which the overt teaching of morals was frowned upon in preference to a more subtle approach. The overall moral orientation of literary works, however, was still considered obligatory.

1809 В. А. Жуковский, „Пнсьмо к издателям ,Вестннка Европы “ Вестник Европы. XLVIII, 21 (1809).

Дсбро, красота мораяьная в самой натуре, отвечает тому, что называется изящным в подражаниях искусства; следовательно, с усовершенствованием одного соединяется и усовершенствование другого. Из всего, мною сказанного, можете заключить, что звание критика и весьма важное и весьма трудное. Вот идеал, составленный мною о его характере: истинный критик будучи одарен от природы глубоким и тонким чувством изящного, имеет проницательный и верный ум, которым руководствуется в своих суждениях; чувство показывает ему красоту там. где она есть. во всех ее оттенках - и самых нежных и самых нечувствительных; рассудок определяет истинную цену ее и не дает ему ослепляться ложным блеском, иногда заменяющим прямо изящное. Он знает все правила искусства, знаком с превосходнейшими образцами изящного; но в суждениях своих не подчиняется рабски ни образцам, ни 
правилам; в душе его существует собственный идеал совершенства, так сказать, составленный из всех красот, замеченных им в произведениях изяшного, идеал, с которым он сравнивает всякое новое произведение художника, идеал возможного, служащий ему верным указателем для определения степеней превосходства. Этого не довольно: чтобы судить о произведениях искусства, которые не иное что, как подражание природе, надлежит хорошо быть знакомым и с самым предметом подражания - с природою.

. . . Истинный критик должен быть и моралист-философ и прямо чувствителен к красотам природы. Скажу более: он должен быть и сам морально добрым или, по крайней мере, иметь в душе своей решительное расположение к добру; ибо доброта моральная, как я уже сказал прежде, служит основанием чувству изящного, и последнее, не будучи соединено с первым, никогда не может иметь надлежащей верности. Наконец, хочу найти в нем пламенную любовь к искусству: он должен иметь о нем понятие высокое; в противном случае никогда не составится в голове его тот идеал совершенства, без которого мысли его не будут ни живы, ни убедительны. . . .

The identity of the esthetic and cthic ideal, the merging of beauty and the good, was an important tenet of late sentimentalism, based on the view that God had endowed nature with beauty so as to exert a moral influence on man. Beauty in nature was conceived as analogous to beauty of the human soul (i.e., virtue). Romantic philosophy gave beauty an even more exalted status. According to Schelling, beauty was the infinite in finite representation, i.e., reflecting absolute identity in art. Compare Zhukovskii's concepts of beauty to those of a Russian adherent of Schelling, Professor A. I. Galich (1783. 1848). Between 1808 and 1813 he studied in Germany. After his return he taught philosophy and literature. His book Opyt nouki iziashchnogo (St. Petersburg, 1825) outlines his views of literature in the spirit of Schelling. Galich said of beauty:

.прекрасное творение искусства происходит там, где свободныи гений человека, как нравственно совершенная сила. запечатлевает божественную. по себе значительную и вечную идею в самостоятельном, чувственно-совершенном. органическом образс" (см. вышс, стр. 75-76).

Beauty was also defined as the synthesis of the good (dobro) and truth (istina). Zhukovskii pointed out this link:

„красота в тесном смысле есть истина, то есть верное сходство изображения с изображасмым . . . В обширном смысле красота есть истина идеальная, то есть не одно ошутительное сходство выражения с выражаемым. но и соединение с ним тоro. что неощутительно, что единственно существует в душе человеческой. по. стигающей нечто высшее, вне видимой материальной природы существуюшее и свойственное ее божественной природе" (В. А. Жуковския. Полное соброние сочинений [Санкт-Петербурr, 1902 ], XV, стр. 27). 
1811 Г. Р. Державин, „Рассужденне о лнрнческой поэзни ити об оде” Чтение в Беседе любителей русского слова, 2 (1811); 6 (1812); 14 (1815).

Вдохновение не что иное есть, как живое ощушение, дар Неба, луч Божества. Поэт, в полном упоении чувств своих разгоряясь свышним оным пламенем или, простее сказать, воображением, приходит в восторг, схватывает лиру и поет, что ему велит его сердие. . . Вдохновение рождается прикосновением случая к страсти поэта, как искра в пепле, оживляясь дуновением ветра; воспламеняется помыслами, усугубляется ободрением, поддерживается окружными видами, согласными с страстью, которая его трогает, и обнаруживается впечатлением, или излиянием мыслей этой страсти, или ее предметов. которые воспеваются. В прямом вдохновения нет ни связи, ни холодного рассуждения. ... .

. . . Лирическое высокое заключается в быстром парении мыслей, в беспрерывном представления множества картин и чувств блестяших, громким, высокопарным, цветушим слогом выраженное, который приводит в восторг и удивление.

1815 В. А. Жуковский, [ Письмо Вяземскому, 19-го сентября 1815 г. ] Собрание сочинений, IV (Москва-Ленннград, 1960).

. . П Поззия есть добродетель, следовательно счастие! Наслаждение какое чувствует прекрасная душа, производя прекрасное в поэзия, можно только сравнить с чувством доброго дела; и то и другое нас возвышает, нас дружит с собою и делает друзьями со всем, что вокруг нас.

1816 В. А. Жуковский, [ Письмо А. И. Тургеневу (лето 1816 г.)] Письма В. А. Жуковского к А. И. Тургеневу (Москва, 1895).

.. Во всяком искусстве, во всякой науке (сказал не помню кто) надобно иметь два или три главных и фундаментальных правила, таких, которые бы можно было применять ко всем или почти ко всем случаям. Жизнь - искусство. И вот два правила, которые едва ли не ко всему пригодятся: совершенствуй волю, все в жизни к прекрасному средство. Первое есть цель всей жизни; последнее может служить масштабом для всякого случая жизни. Нет такого положения, счастливое ли оно или несчастное, которое бы не могло быть средством к прекрасному.

The identification of life with art which led to the stylization of life (e.g., Davydov's 
poetry) and the romanticizing of reality was a central tenet of romanticism, as was the understanding of beauty as the highest guide for life and art. Cf. Novalis: "The world must be romanticized. This way one will find the original meaning again. Romanticism is nothing but a qualitative potentialization. In this process, the lower self becomes identified with a better self." (Novalis, Schriften, III, [Stuttgart, 1960], p. 545).

1815 А. С. Грибоедов, „О разборе волього перевода Бюргеровой баллады Ленора'"

Сын отечества, XXXI, 30 (1816).

Если разбирать творение для того, чтобы определить, хорошо ли оно, посредственно или дурно, надобно прежде всего искать в нем красот. Если их нет - не стоит того, чтобы писать критику; если ж есть, то рассмотреть, какого они рода? Много ли их или мало? Соображаясь с этим только, можно определить достоинство творения.

Griboedov's "beauties" (note the plural) refer to neoclassicist teachings concerning adornments (ukrasheniia) in art. Griboedov, toge ther with Katenin and Kiukhel'beker, was a prominent mladoarkhaist (see above, pp. 3, 39).

1821 В. А. Жуковский, „Дневник, 1821" Дневник (Санкт-Петербург, 1903).

Красота не в природе, а в душе человека.

1823 А. С. Пушкин, [Письмо П. А. Вяземскому ]

О литературе (Москва, 1962), стр. 35.

. . . А романтический трагик принимает за правило одно вдохновение.

1825 Д. В. Веневнтинов, „Утро, полденъ, вечер и ночь” Урания на 1826 год (1826).

Не изгоняйте, друзья мои, из области рассудка фантазии, этой волшебнишы, которой мы обязаны прелестнейшими минутами в жизни и которая, облекая высокое во всю радужную одежду, не искажает светлого луча истины, но дробит его на всевозможные цветы. Не то ли самое делает природа? Но ежели в ней все явления, все причины и действия сливаются в одно целое, в один закон неизменный, - не для того ли созданы все чувства человека, чтоб на богатом древе жизни породить мысль, сей 
божественный плод, приуготовляемый цветами фантазия?

Приятно с верным понятием о природе обратиться к самой же природе, в ней самой искать выражения для того, что она же нам внушила. Все для нас поясняется; всякое явление - эмблема; всякая эмблема - самое целое. . . . Так думал я, пробегая однажды те священные памятники, которые век передает другому и которые свидетельствуя о жизни и усилиях человечества, возрастают с каждым столетием, и, всегда завещанные потомству, всегда представляют новое развитие. Так думал я, пробегая эту цепь превратностей и разнообразия, в которой каждое звено необходимо, которой направление неизменно. И что же представилось разгоряченной фантазия? Простите ли вы, друзья мои, сон воображения, быть может, слишком любопытного, и потому, быть может, обманутого?

Venevitinov, a member of the Moscow circle of tiubomudry, was a follower of Schelling and German romanticism. He expresses essentially romantic views conceming the function of nature as sy mbol and the central role of imagination. Cf. A. W. Schlegel: "Poetry is. if I may say so, speculation of the imagination (fantasy); just as philosophical speculation ascribes the ability to abstract to the mind, so does the poetic speculation attach itself to imagination (fantasy)" (A. W. Schlegel, Kritische Schriften und Briefe. II [Stuttgart, 1963], p. 246).

1828 А. С. Пушкнн, „Отрьвясн из пнсем, мысли и замечания" Северные иветы на 1828 год

Вдохновение есть расположение души к живейшему приятию впечатлений и соображению понятий, следственно и объяснению оных. Вдохновение нужно в геометрин, как и в поэзия.

1835 В. Г. Белинский, „О русской повести и повестях г. Гоголя” Tелескоп. XXVI, 7,8 (1835).

Вдохновение есть страдательное, можно сказать болезненное, состояние души, и его симптомы теперь хорошо всем известны. Человек в горячке. без труда, без усилий и без вреда себе, поднимает ужасные тягости: это называется у медиков энергиею, или напряженным состоянием жизненной деятельности. . . . Вдохновение, в этом смысле, есть энергия души, возбужденная не волею человека, но каким-то не зависящим от него влиянием, и поэтому оно непринужденно и свободно. Есть еще другого рода вдохновение - вдохновение, усиленное волею, желаннем, целию, расчетом, как будто приемом опию. Плоды этого вдохновения иногда блестящи на вид, но их блеск есть блеск фольги, а не золота, блеск, 
тускнеюший от времени. Правда, в ком нет таланта, тому нельзя приходить даже и в напряженный восторг, ибо напрягать можно только что-нибудь существуюшее, положительное, хотя и слабое; напрягать или натягивать чувство, фантазию, словом талант, может только тот, кто, хотя в некоторой степени, владеет всем этим . . .

Способность творчества есть великий дар природы; акт творчества в душе творящей есть великое таинство; минута творчества есть минута великого священнодействия; творчество бесцельно с целит, бессознательно с сознанием, свободно с зависимостию: вот основные его законы. Они будут очень ясны, когда выведутся из акта творчества.

Художник чувствует потребность творить. Это потребность приходит к нему вдруг, нежданно, без спросу и совершенно независимо от его воли. . . .

1842 В. Г. Белинскй, „Речь о критнке"

Отечественные записки, XXIV, 9; XXV, 11 (1842).

Что красота есть необходимое условие искусства, что без красоты нет и не может быть искусства - это аксиома. Но с одною красотою искусство еще не далеко уйдет, особенно в наше время. Красота есть необходимое условие всякого чувственного проявления идеи. Это мы видим в природе. в которой все прекрасно, исключая только те уродливые явления, которые сама природа оставила недоконченными и спрятала их во мраке земли и воды (моллюски, черви, инфузории и т. п.). Но нам мало красоты эмпирической действительности: любуясь ею, мы все-таки требуем другой красоты и отказываем в названии искусства самому точному копированию природы, самой удапной подделке под ее произведения. Мы называем это ремеслом. Какая же та красота, которой жаждет наш дух, не удовлетворяющийся красотою природы, и которой мы требуем от искусства? Красота мира идеального. мира бесплотного, мира разума, где от века заключены все прототипы живых образов, откуда исходит все, реально существенное. Следовательно, красота есть дщерь разума, как Афродита - дщерь Зевеса.

1848 В. А. Жуковский, [Письмо к Гогопю от 20-го января, 1848 г.] Полное собрание сочинений, X (Санкт-Петербург, 1902), стр. 82.

. . Прекрасное существует, но его нет, вбо оно, так сказать, является нам единственно для того, чтобы исчезнуть, чтобы нам сказаться, оживить и обновить душу - но его не удержать, ни разделять, ни постигнуть 
мы не можем . . . оно посещает нас в лучшие минуты жизни - величественное зрелище природы; еще более величественное зрелище души человеческой - поззия; счастие, но еще более несчастия дают нам сии высокие ощущения прекрасного; и весьма понятно, почему почти соединяется с ними грусть, - но грусть, не приводящая в уныние, а животворная, сладкая, какое-то смутное стремление. Это происходит ot его скоротечности, от его невыразимости, от его необъятности. Прекрасно только то, чего нет . . . Эта грусть убедительно говорит нам, что прекрасное здесь не дома, уто оно только мимо пролетающий благовеститель лучшего, оно есть восхитительная тоска по отчизне! Оно действует на нашу душу не настоящим, а темным, в одно мгновение соединенным воспоминанием всего прекрасного в прошедшем и тайным ожиданием чего-то в будущем:
А когда нас покидает,
В дар любви у нас в виду
В нашем небе зажигает
Он прощальную звезду.

Это верное сравнение! Это прощальная и навсегда остающая звезда в нашем небе есть знак того, что прекрасное было в нашей жизни, и вместе того, что оно не к нашей жизни принадлежит! Звезда на темном небе - она не сойдет на землю, но утешительно сияет нам из дали: и некоторым образом сближает нас с тем небом, с которого неподвижно нам светит! Жизнь наша есть ночь под звездным небом - наша душа в минуты вдохновения открывает новые звезды; эти звезды не дают и не должны давать нам полного света, но, украшая наше небо, знакомя с ним, служат в то же время и путиводителями по земле.

Zhukovskii expresses the romantic feeling of longing for an ideal (beauty) whose intangible nature leads the poet to melancholy, if not despair. Friedrich Schlegel had defined Sehnsuch (longing) as the basis of the feeling of beauty. Dissatisfied with reality, the romantic poet searched for the ideal which appeared to him in beauty, yet due to its ideal nature remained out of his reach. 


\section{PART FOUR}

\section{Interpretations III - Style and Genres}




\title{
STYLE AND GENRES
}

\author{
Introduction
}

An essential aspect of early romanticism was an at tempt to define the individuality of European nations as opposed to the abstract models of antiquity which had dominated classicist literature. Greek and Roman mythology were replaced by indigenous Germanic, Scandinavian, Celtic and Slavic mythologies. Folklore and fairy tales were investigated and collected. Macpherson's Ossianic poems (1765, translated 1788), Bishop Percy's Reliques of Ancient Poetry (1765), Mallet's collection of Scandinavian sagas (Monuments de la mythologie et de la poésie des Celtes, et particulièrement des anciens Scandinoves, 1756, translated 1785), and Herder's Volkslieder (1778.1779) were powerful stimuli in the at tempt to define national literatures.

Initially, two national cultural types were opposed to each other, Greek civilization of antiquity and Northern or Ossianic culture. Each cultural type had its own specific stylistic characteristics. According to Herder, both were of equal significance and stature. Mme de Stael spread her understanding of two cultural and literary types in her book De la littérature considérée sous ses rapports avec les institutions sociales (1800) and again in De l'Allemagne (1813), especially in the chapter "Concerning Classical and Romantic Poetry." This view had been prepared by the geographical theory of Montesquieu who had stressed the influence of climate and geographical environment in the evolution of nations.

Romantic authors redefined Greek culture. In contrast to the abstract and artificial views of classicist authors, they stressed the primitive nature of ancient Greece, the heroic and natura' way of life. Katenin's poems ("Sophocles," "Achilles and Homer," "Sappho") and his tragedy Andromache express this romantic view which we also find in the poetry of Gnedich. Another frequently met opposition was that of Northern, Ossianic style with the literature of romance countries (Spain, Italy, and France) which were described as constituting the Souther cultural and stylistic type. In the romantic understanding, ancient Greek civilization and literature was also assigned to the Southern type. Simonde de Sismondi's study of Italian literature, De la littérature du Midi de l'Europe (1813), stressed the role of Southem European literature in the evolution of romanticism.

A third cultural and literary type was defined as Eastem. The 18th century had already shown an interest in Eastern countries such as Persia, India, and China. Sanskrit epic poems (Sakontala) were studied and trans- 
lated. Jean François Champollion deciphered Egyptian hieroglyphs. Scholars began to study Arabic literature (e.g., Senkovskii in Russia). The Koran became a fashionable book. Hebrew literature, the Bible and especially the psalms were considered examples of Eastern style. The biblical image of the poet-prophet, the liberator of the Israelites from pagan domination, was used by early romantic writers to express their own desire for freedom from oppression. The strong anti-despotic trend in preromantic literature often availed itself of biblical motifs.

Russian romantic writers stressed the geographical situation of the Russian Empire which included all three cultural types within its borders, from the North (Finnish possessions) to the South (Crimea and Bessarabia), and the East (the deserts of Asiatic Russia). The conclusion was that Russian romantic writers were in a particularly advantageous position, since all three cultural types were part of their national heritage.*

Another fundamental stylistic division was based more on chronological than on geographic criteria. Friedrich Schiller (as before him Rousseau) stressed the different attitudes to writing exhibited by the Greeks and the European nations of modern times. The Greek attitude, being the expression of a people in close contact with nature, at the threshold of civilization, was defined as naive, in contrast to the European attitude where civilization had made it impossible for the writer to preserve the same immediacy and closeness to his environment. The modern writer was considered mostly sentimental (in the sense of reflective). Zhukovskii echoed these views in his essay "O poezii drevnikh i novykh" (1811).

In the area of genres, considerable changes took place in the course of the literary evolution. Sentimentalism had already brought about essential changes in the classicist system of well-defined genres. In the area of poetry, the ode lost its cumbersome adornments in the work of Sumarokov, Kheraskov, and Murav'ev. It was gradually replaced by light poetry, anacreontic verse, and lyrical poetry of an intimate and personal type. The serious drama of Diderot introduced a similar change in the dramatic genre. Classicist tragedies and comedies were replaced by the middle-class tragedy and the tearful comedy. Prose, admitted by the classicist only in form of didactic novels, sermons, and orations, came to assume a prominence unprecedented in Russian literary history. The sentimental and romantic novel stressed the analysis of individual emotions. It often exhibited a confessional character and a loose and essayistic structure, especially in the popular travelogue.

In the eyes of the romantic writer all arts and genres merged and constituted one whole, which corresponded to another such organic wholenature. Art was discussed under three aspects: the picturesque, musical, and plastic. The brothers Schlegel in Germany maintained that Greek and Roman art had been plastic, while modern, romantic art (including the middle-ages)

- Cf. G. A. Gukovskï, Pushkin i russkie romantiki (Moskva, 1965), pp. 233, 237, 258-259, 271. 
exhibited the characteristics of the picturesque and the musical. The plastic arts of architecture and sculpture were considered lower in rank, since their form was determined by their material (corporeal or veshchestvennyi) nature. Painting and music, expressing a higher degree of spirituality, were closer to the heart of the romantic. The main point, however, was that all arts were one and any given art included elements of all others. Genres were no longer strictly separated. Classicist "rules" were disregarded.

The lyrical, poetical element arising from the romantic author's intense consciousness of his subjective individuality and the exalted role assigned to him by nature came to dominate all genres. Karamzin had already defined all works of imagination as "poema," and Zhukovskiii even considered all arts "poeziia $v$ raznykh formakh." It was natural to write "a novel in verse" (Pushkin's Evgenii Onegin), or "a poem in prose" (Gogol's Mertvye Dushi). The romantic age began as an age of poetry, Russia's Golden Age of Poetry.

Despite its leading role in preromantic literature (corresponding to German Storm and Stress), drama was a minor genre in romantic literature. In the romantic understanding, the essence of the comic consisted in the contradiction between the real and the ideal (Schelling)-in Galich's words, "protivorechie veshchi s ee poniatiem i naznacheniem" (A. Galich, Opyt nauki iziashchnogo [Sankt-Peterburg, 1825], p. 45). By revealing the contrast between an imperfect reality and an intangible ideality, the romantic playwright evoked laughter. E. T. A. Hoffmann said that only he who was able to laugh understood the genuine meaning of life. However, the comic and tragic were closely related. E. T. A. Hoffmann spoke of this unity: "Comic and tragic elements will merge willingly only in the truly romantic so that both will become one in their total effect, and will captivate the mind and heart of the audience in a peculiar, and wonderful manner" (cf. his Gesammelte Schriften [Berlin, 1871-1873] , I, p. 87), and Gogol's "laughter through tears" gave further expression to it. As one reviewer said of Gogol's Revizor, "Da, ona smeshna, tak skazat', snaruzhi; no vnutri eto gore gorevan'itse, lykom podpoiasano, mochalami isputano. . ." ("Teatral'naia khronika," Moiva, 9, 1835, p. 257).

The tragic was defined by Schelling as the contradiction between the subjective freedom of the individual and objective necessity, both of which simultaneously triumph and suffer defeat. This understanding of the tragedy was particularly well-suited for historical tragedies, a genre which was popular in the 1830's in Russia.

It was also in the 1830's that the importance of prose increased. The historical novel, stimulated by translations from Walter Scott, unfolded in the works of Zagoskin and Lazhechnikov. Lermontov's book Geroi nashego vremeni (1840) and Gogol's Pokhozhdeniia Chichikova, ili Mertvye dushi (1842) indicated the victory of prose over the other genres. F. Schlegel had once described the novel as "an encyclopedia of the entire spiritual 
life of an individual of genius" (Kritische Fragmente, no. 78). The novel, a central genre in German romanticism, represented human life, struggle, achievement and failure in an organic totality analogous to life itself and inaccessible to any other genre. The novel was "a romantic book" per se (F. Schlegel, Athenëum, 1800).

Apart from the confessional element (going back to Rousseau's Confessions, 1765-70), the novel was characterized by a structural design which was described by a term from architecture-the arabesque ("a complex and elaborate design of intertwined flowers, foilage, geometrical patterns..." (Webster's Dictionary/). F. Schlegel called the arabesque in literature "the most original form of human imagination," "an artificially ordered confusion," "the delightful symmetry of contradiction," "the wonderful, eternal change from enthusiasm to irony" (Athenäum). Its purpose was described as "suspending the course and the laws of rationally thinking nature to transfer us back again to the beautiful confusion of imagination, the original chaos of human nature" (ibid.). Gogol's collection of stories of 1835 was characteristically entitled Arabeski.

Towards the end of the 1830's and in the course of the 1840's a new prose genre, the physiological sketch, reached Russia from France. These popular sketches of social and professional types, types of environiment, and institutions heralded the approaching age of realism. The Natural School (the name natural'naia shkola seems to have been coined by Bulgarin in 1846) merged with the physiological sketch in the middle 1840's. Nekrasov's publication of the miscellany Fiziologiia Peterburga in 1845, and Peterburgskii Sbomik a year later, indicated the beginning of realism in Russian literature. Belinskii's introduction to the volume Fiziologiia Peterburga was the manifesto of the new Natural School. The passage from romanticism to realism was marked by the final victory of prose over poetry and drama. 


\section{THREE ROMANTIC STYLES}

1809 Г. Р. Державин, [Предисловие к трагедин]

Ирод и Мариамна (Санкт-Петербург, 1809).

Впрочем, жестокие кровожаждущие выражения, а также восточный слог употребил я нарочно, дабы сколько возможно ближе и изобразительнее представить характер еврейского народа.

Irod $i$ Mariamna. Derzhavin's furst tragedy, was written in 1807. Derzhavin used Josephus Flavius' account of the Judean war as his source (translated as $O$ woine Iudeiskoi [SanktPeterburg, 1786-1787|). The "Eastern style" also referred back to works of French authors like Montesquieu's Lettres persannes (1721) and Voltaire's novels and taks which often used the devices of oriental fairy tales. This style often served the purpose of concealing incisive criticism of the conditions of the age in the guise of an exotic tale. Krylov's story "Kaib" (1792) and Benitskii's tales of the early 1800's (e.g., "Vizir," "Beduin," "Na drugoi den'," "Indiiskaia skazka") were examples of this style in Russian literature. Cf. p. 180 below.

1810 К. Н. Батюшков, [Письмо Н. И. Гнедичу от мая 1810 г.] Сочинения. III (Санкт-Петербург, 1885-1887)

ПІарни признан лучшим писателем в роде легком (этот род сочинений весьма труден). Его поэма Les Scandinaves прекрасна: стихи мною переведенные, были внесены профессором Ноэлем. членом парижского института, в примеры прекрасного и живописной поэзии. Теперь: мой перевод дурен? . . .

Кажется, перевод мой не хуже подлинника. . . .

Это все в тоне северной поззии, которую, конечно, отличать должно от греческой; это все у места, и кажется, нет ничего надутого. ложного; притом же и язык чист и благороден.

Parni-Evariste Désiré de Forges, Vicomte de Parny (1753-1814). French poet known for his sensual love poems (Poésies érotiques. 1778-1784).

1815 К. Н. Батюшков, „Нечто о поэте и поэзнн"

Опыты в стихах и прозе К. Н. Батюшкова. I (Санкт-Петербург, 1817).

Климат. вид неба, воды и земли - все действует на душу поэта, 
отверстую для впечатлений. Мы видим в песнях северных скальдов и зрских бардов нечто суровое, мрачное, дикое и всегда мечтательное, напоминающее и пасмурное небо севера, и туманы морские, и всю природу, скудную дарами жизни, но всегда величественную, прелестную и в ужасах. Мы видим неизгладимый отпечаток климата в стихотворцах полуденных: некоторую негу, роскошь воображения, свежесть чувств и ясность мыслей, напоминающих и небо и всю благотворную природу стран южных, где человек наслаждается двойною жизнию в сравненин с нами, где все питает и нежит его чувства, где все говорит его воображению. Напрасно уроженец Сицилии или Неаполя желал бы состязаться в песнях своих с бардом Морвена и описывать, подобно ему, мрачную природу севера; напрасно северный поэт желал бы изображать роскошные долины, прохладные пещеры, плодоносные рощи, тихие заливы и небо Сицилии, высокое, прозрачное и вечно ясное. Один Тасс, рожденный под раскаленным солнцем Неаполя, мог описать столь.верными и свежими красками ужасную засуху, гибельную для крестовых воннов. По сему описанию, говорит ученый Женгене, можно узнать полуденного жителя, который неоднократно подвергался смертному влиянию ветров африканских, неоднократно изнемогал под бременем зноя.

Stikhotvortsy poludennye refers to Southern style, especially Italian poetry (Torquato Tasso, 1544-1595).

Bard Morvena-Ossian.

Zhengene-Pierre-Louis Ginguené (1748-1816), French poet and critic, lectured on Italian literature and published a Histoire litteraire d'tralie (1811-1824).

1817 П. А. Вяземский, „О жнзни и сочннениях Озерова” Сочинения Озерова, I (Санкт-Петербург, 1817).

Воображение Омера богато, роскошно и разноцветно, как вечная весна, царствующая на отеческих его полях. Воображение Оссиана сурово, мрачно, однообразно, как вечные снега его родины. И у него одна мысль, одно чувство: любовь к отечеству, и сия любовь согревает его в холодном царстве зимы и становится обильным источником его вдохновения. Его герои - ратники. Поприще их славы - бранное поле. Алтари - могилы храбрых. Северной поэзии прилично искать источников в баснословных преданиях народа, имеющего нечто общее с ее народом, когда разборчивая строгость не дозволяет ей дополнить своими вымыслами скудные средства открытые отечественной историей. Северный поэт переносится под небо, сходное с его небом, созерцает природу, сродную его природе, встречает в нравах сынов ее простоту, в подвигах их мужество, которые рождают в нем темное, но живое чувство убеждения, что предки его горели тем же мужеством, имели ту же простоту 
В нравах, и что авойства сих однородных диких сынов севера отлиты были природою в общем льдистом сосуде. Самый язык наш представляет более красот для живописной северной природы. Щвет поэзии Оссиана может быть удачнее обильного в оттенках цвета поэзия Омеровой перенесен на наш язык... Трагедия Фингал - торжество северной поэзии. . . . В Фингале ничто не забыто ни трагиком, ни поэтом. Тот и аругой взял с Оссиана полную дань. Счастливый приемник Озерова может приняться после него за Эдипа, частью сравняться с ним, а частью и превзойти его; но едва ли дерзнет кто-нибудь по следам его искать добычи в поэмах Оссиана. Он найдет поле, уже пожатое и обнаженное рукою счастливою и искусною в выборе. Представление Фингала говорит воображению, сердиу и глазам зрителя. Тут все у места: пение бардов, хоры жрещов, сражения. Все сии принадлежности, во многих трагедиях часто излишние, в Фингале нужные, тесно связаны с главным содержанием и, так сказать, идут не за сочинителем, а за действуюшими лищами.

Гомер/Oмер $=$ Homer .

Ozerov (1769-1816) was a poet and playwright who wrote tragedies based on subjects from Macpherson's Ossianic poems (Fingal. 1805), Greek literature (Poliksena. 1809; Edip y Afinakh. 1804), and Russian history (Dmitrii Donskoi. 1807). Viazemskii defined Ozerov as a romantic writer, which was disputed by Pushkin. See above, p. 88.

1820 А. Ф. Мерзляков, ,Державин"

Труды Общества любителей российской словесности. XXVII, $17-18$ (Москва, 1820).

Два первые наши поэта дышут в стихах своих тем климатом. который воспитал их: - в Ломоносове чаще всего встречиваются картины севера; в Державине, потомке Багрима - повсюду великолепие востока, бесчисленно разновидные изображения благотворений солнща. нега. роскошь. благоуханные розы, пушистой кавыль и тундры.

Derzhavin. potomok Bagrima-Derzhavin's ancestors were Tartars. one of whom (Abragim = Bagrim) joined grandprince Vasilii Vasil'evich (14th century), was baptized, and assumed the name II'ia. Merzliakov links Derzhavin's Eastern style to his family background.

1822 А. С. Пушкин, [Пнсьмо П. А. Вяземскому от 2 января, 1822 г. ] Собрание сочинений. IX (Москва, 1962).

. . . Жуковский меня бесит - что ему понравилось в этом Муре? Чопорном подражателе безобразному восточному 
воображению? Вся Лалла-Рук не стоит десяти строчек Тристрама Шанди; пора ему [Жуковскому] иметь собственное воображение и крепостные вымысли.

Mur - Thomas Moore (1799-1852), Irish poet, author of a verse epic Lalle Rookh (1817), translated by Zhukovskii in 1821 .

The Life and Opinions of Tristram Shandy (1760-1767) is a novel by Laurence Sterne (1713-1768).

1823 О.М. Сомов, „О романтической поэзия” (статъя III ).

Соревнователь просвещения и благотворения, 9 (1823).

Прекрасные стихотворения Пушкина то дышат суровым севером и завиваются в седых его туманах, то раскаляются знойным солнцем полуденным и освещаются яркими его лучами. Поэт обнял все пространство родного края и в своенравных играх своей Музы показывает его нам то с той, то с другой стороны, является нам на хладных берегах Балтийских - и вдруг потом раскидывает шатер под палящим небом Кавказа или резвится на цветуших долинах Киевских. . . .

Упреки, делаемые природе, и того неосновательнее. Где же она разнообразнее, как не в Россин? Несколько зон опоясывают ее пространство, несколько климатов являются в ней, изменяя постепенно вид земли с ее произведениями. . . . Какая из новых стран заключает в себе столько богатств поэтических? Здесь воспоминания юга и предания севера объемляются между собою; природа и человек, прошедшее и настоящее говорят поэту: выбирай и твори!

See above, p. 175.

1824 А. С. Пушкин, [ Письмо П. А. Вяземскому, от 5-го июля 1824 г. ] Пушкин о литературе (Москва, 1962).

Никто более меня не любит прелестного André Cheniér, но он из классиков классик - от него так и несет греческой поззией.

André Chenier (1762-1794), a French poet, initially was an adherent of the French revolution, yet became one of the last victims of Robespierre's reign of terror. His works were published posthumously in 1819 and created a sensation. Greek mythology, a feeling for harmony, grace, simplicity, and plastic beauty characterized his poems. Romantic writers accepted him as their forerunner. Belinskii wrote in 1844, "Andre Shen'e byl otchasti uchitelem Pushkina $v$ drevnei klassicheskoi poezii, i v elegii, oznachennoi imenem frantsuzskogo poeta; Pushkin mnogimi prekrasnymi stikhami verno vosproizvel ego obraz" (V. G. Belinskii, "Sochineniia A. Pushkina," stat'ia piataia. Otechestvennye zapiski, XXXII, 2 [1844], pp. 43-83. 
1824 В. Кзохельбекер, „О направленнн нашей поэзнн,_особенно лнрнческой в последвее десятилетне"

Мнсмозина, 11 (Москва, 1824).

Но что такое поззия романтическая?

Она родилась в Провансе и воспитала Данта, который дал ей жизнь, силу и смелость, отважно сверг с себя иго рабского подражания римлянам, которые сами были единственно подражателями греков, и решился бороться с ними. Впоследствии в Европе всякую поззию свободную, народную стали называть романтическою. Существует ли в сем смысле романтическая поззия между немцами?

Исключая Гете, и то только в некоторых, немногих его творениях, они всегда и во всяком случае были учениками французов, римлян, греков, англичан, наконец, италиянцев, испанцев. Что же отголосок ux произведений? Что же наша романтика?

Не будем, однако же, несправедливы. При совершенном неведения древних языков, которое отличает, к стыду нашему, всех почти русских писателей, имеюших некоторые дарования, без сомнения знание немецкой словесности для нас не без пользы. Так, напр., влиянию оной обязаны мы, что теперь пишем не одними александринами, четырехстопными ямбическими и хореическими стихами.

Изучением природы, силою, избытком и разнообразием чувств. картин, языка и мыслей, народностию своих творений великие поэты Греции, Востока и Британии неизгладимо врезали имена свои на скрижалях бессмертия. Ужели смеем надеяться, что сравнимся с ними по пути, по которому идем теперь? Переводчиков никто, кроме наших дюжинных переводчнков, не переводит. Подражатель не знает вдохновения: он говорит не из глубины собственной души, а принуждает себя пересказать чужие понятия и ощущения. Сила? - Где найдем ее в большей части своих мутных, ничего не определяющих. изнеженных. бесцветных пронзведениях? У нас все мечта и призрак. все мнится и кажется и чудится. все только будто бы, как бы. нсчто. что-то. Богатство и разнообразие? - Прочитав любимую элегию Жуковского, Пушкина или Баратынского, знаешь все. Чувств у нас уже давно нет, чувство уныния поглотиіо все прочие. Все мы взапуски тоскуем о своей погибшей молодости; до бесконечности жуем и пережевываем эту тоску и наперерыв щеголяем своим малодушием в периодических изданиях. Если бы сия грусть не была просто реторическою фигурою, иной, судя по нашим Чайльдам-Гарольдам, едва вышедшим из пелен, мог бы подумать, что у нас на Руси поэты уже рождаются стариками. 
Картины везде одни и те же:луна, которая - разумеется - уныла и бледна, скалы и дубравы, где их никогда не бывало, лес, за которым сто раз представляют заходящее солнце, вечерняя заря; изредка длинные тени и привидения, что-то невидимое, что-то неведомое, пошлые иносказания, бледные, безвкусные олицетворения Труда, Неги, Покоя, Веселия, Печали, Лени писателя и Скуки читателя; в особенности же туман: туманы над водами, туманы над бором, туманы над полями, туман в голове сочннителя.

1825 А. С. Пушкин, [Письмо Вяземскому от марта-апреля 1825 г. ] Собрание сочинений, IX (Москва, 1962).

Кланяйся Давыдову, который забыл меня. Сестра Ольга в него влюблена, и поделом. Кстати или нет: он критиковал ей в Бахчисарайском фонтане Заремины очи.Я бы с ним согласился, если 6 дело шло не о востоке. Слог восточный был для меня образцом, сколько возможно нам, благоразумным, холодным европейцам. Кстати еше - знаешь, почему не люблю я Мура? - Потому что он черезчур уже восточен. Он подражает ребячески и уродливо - ребячеству и уродливости Саади, Гафиза и Магомета. - Европеец и в упоении восточной роскоши должен сохранить вкус и взор европейца. Вот почему Байрон так и прелестен в Гяуре, в Абидосской невесте и проч.

Mur-Thomas Moore (1799-1852), see above, p. 180f. Saadi-Saadi (1215-1292), Persian poet. Gafiz-Hafez (1326-1390), Persian poet. Mogomet-Mohammed. Giaur-"The Giaour" (1813), a tale in verse by Byron. Abidosskaia nevesta - "The Bride of Abydos" (1814), a tale in verse by Byron.

1827 П. А. Вяземскнй, „06 алманахах 1827 года"

Полное собрание сочинений П. А. Вяземского, I (Санкт-Петербург, 1879).

Талант барона Дельвига имеет отличительные свойства, не сливающиеся с господствующими признаками нашего времени. Поэзия еro, как воды Аретузы, сохраняющие свежую сладость свою и при впадении в море, протекает между нами, не заимствуя ни красок, ни вкуса разливавшегося потока. Первобытная простота, запах древности, что-то чнстое, независимое, целое в соображениях и в испольении, служат знамением и украшением лучших его произведений. Его русские песни и стихотворения во вкусе древних, как, например, Друзья и гений-хранитель, напечатанные в Северных иветах нынешнего года, поражают какой-то 
прелестью древней, но никогда не стареющей: так, отыскиваемые драгоценные памятники искусства веков первобытных занимают почетное место и посреди блестящих и гордых свидетельств нового просвещения. Если поэт и здесь продолжатель, то, по крайней мере, он не ученический переписчик: перерождаясь в древних, он дает старине своеобразие новизны.

Aretuze-In Greek mythology the name of a spring, also a nymph near Syracuse. Severnye tsvety (1825-1832), an almanac edited by A. A. Del'vig, published the works of Russian romantic writers. Ivan Kireevskii said of Del'vig's poetry: "Ego muza byla v Gretsii, ona vospityvalos' pod teplym nebom Attiki: ona naslushalas' tam prostykh, estestvennykh, svetlykh i pravil'nykh zvikov liry grecheskoi, no ee nezhnaia krasa ne vynesla by kholoda mrachnogo severa, esli by poet ne prikryl ee nasheiu narodnoiu odezhdoiu. esli by na ee klassicheskie formy on ne nabrosil dushegreiku noveishego unyniia,i ne $k$ litsu li Grechanke nash severnyi nariad?" Polnoe sobronie sochinenii. I [Moskva. 1911 , p. 31).

N. I. Gnedich (1784-1833) was another philhellenic poet. He translated Homer's Miad, also Prostonarodnye pesni nyneshnikh Grekov, and wrote poems on Greek themes.

1831 Е. Мещерский, „О литературе русской” (речъ)

Литературная газета. 7( 31 янв. 1831).

Легко так же доказать, что дух романтизма свойствен и природе российской. Может ли поэзия народная соблюсти характер точный, определенный и общий, там, где одним и тем же языком говорят на диких и безплодных берегах Ледовитого моря, и на злачных, очаровательных холмах Тавриды? Там, где душа посменно раскрывается и уносится за пределы свои при виде природы, источающей наружу все свои растительные силы; и там. где с другой стороны, душа сжимается и как бы прячется в себе самой, когда сочувствует природе угрюмой и сжатой? Отсюда происходит колорит часто восточный либо итальянский, и суровость, глубокость скандинавская в воображении русского. Гранищы поэтического духа в России по необходимости должны быть столь же пространно раздвинуты, как и гранищы империи Российской.

Скажу более: Петербург, с своими инеями и льдами, с своими 18-ти часовыми ночами зимой, и своей весною, зараждающею сего дня шветок на том месте, где вчерась едва растаял снег, - Петербург, со своим летом, когда нескончаемый день беспрерывно освещает величавую поверхность Невы, на которой плавают зеленые острова, покрытые виллами и дворцами итальянскими, - Петербург, с своим чрезмерным зноем, заставляюшим переходить от деятельности жителя севера, $k$ dolce far niente обитателя юra: Петербург один, говорю, есть уже романтизм в том смысле, как мы его разумеем. 
Elim Meshcherskii (1808-1844), a poet writing in French, served with the Russian embassy in Turin and Paris. He published De la littérature russe (Marseille, 1830), Les Boreales. translations in verse of Russian poets, (Paris, 1839), Les poétes russes, traduits en vers francais (Paris, 1846), etc. His speech on Russian literature was partially reprinted in Russian by O. M. Somov in Pushkin's Literatumaie gazeta. Somov had expressed similar views on the Russian nature and climate as beneficial for romantic literature in his three essays on romanticism in 1825 (see above, pp. 129, 181).

1833 А. А. Бестужев-Марлинскй, „О романе Н. Полевого, „Клятва при гробе Господнем' "

Московский телеграф, $15-18$ (1833).

Светлое небо Эллады отражалось не только в водах Эгейского моря, но и в душах, в правах, гармоническом языке героев. Восточная поэзия чувственность и гроза, греческая - вся чувство верное, пылкое чувство, которое пленялось родною, величественною природою, которое рвалось из груди на простор, точно так же как сам грек всю жизнь проводил на воздухе, на раздолье. . . .

. . . Странное дело: Востоку суждено было искони высылать В другие концы мира, с индиго, с кошенилью и пряностями, свои поверья и верования, свои символы и сказки; но Северу предлежало очистить их от грубой коры, переплавить, одухотворить, идеализировать. Восток провещал их в каком-то магнетическом сне, бессвязно, безответно; но Север возрастил их в теплице анализа, - ибо Восток есть воображение, а Север - разум.

Elloda-Hellas (i.e., ancient Greece); Egeiskoe more-Aegean sea.

1834 К. А., „О новом направленин в русской словесностн” Московский телеграф, II (1834).

История наша, соединяющая в себе три рода поэзии - Восток, Запад и Север - представляет такое разнообразие, каким могут похвалиться немногие народы.

K. A. $=$ K. A. Polevoi

1841 В. Г. Белинский, „Римскне элегин"

Отечественные записки, XVIII, 8 (1841).

Первый начал у нас писать в антологическом роде Державин. В свонх так 
называемых анакреонтических стихотворениях он является тем же, чем и в оде, - человеком, одаренным большими поэтическими силами, но не умевшим управляться с ними по недостатку вкуса и художественного такта. В целом, все пронзведения Державина - какие-то безобразные массы грубого вещества, блещушие драгоценными камнями в подробностях. Но целого у него никогда не ишите; превосходнейшие стихи перемешаны у него с самыми прозаяческими, пленительнейшие образы с самыми грубыми и уродливыми. Потому-то Державина теперь никто не читает, хотя и все справедливо признают в нем огромный талант. . . .

Державин только начал; но действительно познакомили нас с духом древней классической литературы, и переводами и оригинальными произведениями, два поэта - Гнедич и Батюшков: первый свонм переводом „Илиады” - этим гигантским подвигом великого таланта и великого труда, переводом ициллии Теокрита „Сиракузянки”, собственною идиллиею „Рыбаки” и другими произведениями. Муза Батюшкова была сродни древней музе. Жаль только, что дух времени и французская зстетика лишили этого поэта свободного и самобытного развития. До Пушкина не было у нас ни одного позта с таким классическим тактом, с такою пластичною образностию в выражении, с такою скульптурною музыкальностию, если можно так выразиться, как Батюшков.

Tcokrit-Theocritos (3rd cent. B.C.), Greek poet, wrote buccolic poetry. Concerning Gnedich see p. 126 above.

1842 Е. Болховнтнов, „О славенорусских лириках" Москвитянин. I (1842).

Древние русские стихотворения, изданные г. Ключаревым с изустных преданий, представляют смесь древних произшествий и обычаев с новейшими, и все почти состоят из повторения одинаковых картин, в которых при всем том заметны порывы северной скандинавской лирической поззии . . . сравнения и противоположения, загадки, аллегории, смелые метафоры, простонародные поговорки и хвастовство удальством составляют также отличительное свойство северной поззии.

E. Bolkhovitinov (1767-1837). Bishop of Kiev, was the author of Slovar rossiiskikh pisatelei (begun 1804, published 1838). F. P. Kliucharev (1754-1820's), civil servant and writer, collaborated with N. I. Novikov. He published poems in a mystical, pietistic spirit. The first edition of Drevnie russkie stikhotvoreniia (Moskva, 1804), collected by Kirsha Danilov, was falsely ascribed to Kliucharev. A third edition appeared in 1818. 
1843 В. Г. Белннския, „Сочнневия Александра Пушкина” (статья III) Отечественные записки, XXX, 9 (1843).

„Отрывок из писем офицера о Финляндии" показывает, что фантазия Батюшкова была поражена двумя крайностями - югом и севером, светлою, роскошною Италиею и мрачною, однообразною Скандинавиею. Эта статья написана как будто бы в соответствие с элегиею „На развалинах замка в Швеции". Язык и слог этой статьи сльли за образцовые, и вообще она считалась лучшим произведением Батюшкова в прозе. А между тем она есть не что иное, как перевод из „Harmonie de la Nature" Ласепеда; отрывок, переведенный Батюшковым, можно найти в любой французской хрестоматии, под названием: „Les forets et les habitants des regions glaciales". Сказанное Ласепедом о Северной Америке Батюшков храбро приложил к Финляндия - и дело с концом!

Batiushkov participated in the Russian war against Sweden (1807-1808) in Finland and noted his impressions in the above-mentioned Otryvok iz pisem russkogo ofitsera $o$ Finlandii (published in vol. II of his Opyty $v$ stikhakh $i$ proze [Sankt-Peterburg, 1817\}).

"Harmonies de la Nature"-poem by Bernard Germain Etienne de la Ville-surIllon, Comte de Lacepede (1756-1825), writer and naturalist.

1843 В. Г. Белинския, „Сочннения Александра Пушкина” (статъя II) Отечественные записки, XXX, 9 (1843).

Восток - колыбель человечества и царство природы. Человек на востоке - сын природы: младенцем лежит он на груди ее и старцем умирает на ее же груди. Восток и теперь остался верен основному закону своей жизни - естественности, близкой к животности. Любовь на востоке навсегда осталась в первом моменте своего проявления: там она всегда выражала и теперь выражает не более, как чувственное, на природе основанное, стремление одного пола к другому. Само собою разумеется, что первый и основный смысл любви заключается в заботливости припроды о поддержании и размножении рода человеческого. Но если 6 в любви людей все ограничивалось только этим расчетом природы, люди не были бы выше животньх. Следственно, это чувственное стремление в любви человека одного пола к человеку другого пола есть только один из элементов чувств любви, его первый момент, за которым, в развитии, следуют высшие, более духовные и нравственные моменты. Востоку суждено было остановиться на первом моменте любви и в нем найти полное осуществление этого чувства. Отсюда 
вытекает семейственность, как главный и основный элемент жизни восточных народов. Иметь потомство - первая забота и высочайшее блаженство восточного жителя; не иметь детей - это для него знамение небесного проклятия, нравственного отвержения. По закону иудейскому, бесплодные женшины были побиваемы каменьями, как преступнишы. Отшы там женили сыновей своих еще отроками; брат должен был жениться на вдове своего брата, чтобы восстановить семя своему брату. Отсюда же выходит и восточная полигамия (многоженство) . Гаремы существовали на Востоке всегда, и их нельзя считать исключительно принадлежащими исламизму. Обитатель Востока смотрит на женщину как на жену или как на рабыню, но не как на женщину: потому что от женшины мужчина всегда добывается взаимности, как необходимого условия счастливой любви, - от жены или рабы он требует только покорности. Для него это вещь, очень искусно приноровленная самою природою для его наслаждения; кто же станет церемониться с вещию? Мифы - самое верное свидетельство романтической жизни народов. В мифах Востока мы не находим еще ни идеала красоты. ни идеала женщины. Все мифы его по преимуществу выражают одно неутолимое вожделение, одно чувство: слалострастие, - одну идею: вечную производительность природы.

1844 В. Г. Белинския, „Сочннения Александра Пушкина“(статья V) Отечественные записки. XXXII, 2 (1844).

Подрахания корану, вполне передаюшие дух исламизма и красоты арабской поэзии - блестяший алмаз в поэтическом венце Пушкина! „В крови горит огонь желанья”, „Вертоград моей сестры”, „Пророк” и большое стихотворение, род поэмы, исполненой глубокого смысла и названной „Отрывком”, представляют красоты восточной поэзии друroro характера и высшего рода и принадлежат к величайшим произведениям пушкинского гения-протея.

"Otryvok" refers to the poem "Odnazhdy stranstruia sredi doliny dikoi. .."

1844 П. А. Плетнев, „Наль и Дамаянти, индеясккая повесть В. А. Жуковского” Современник, XXXIII (1844).

Ныне перешагнул он [Жуковский] в новый мир, столь от нас отдаленный и эпохою событий, изображаемых в нем, и местными красками, которых чудные переливы внесла в поэму восточная природа с 
восточным воображением. Наль и Дамаянти - эпизод Магабараты. . . . Созерцание и ошушение - два источника, из которых и образуется этот характер поэзии, не гоняющейся за драмами страстей и приключениями жизни, а превратившейся в сладостное сознание красоты и бытня.

Magabarata-Mahobharato, in the understanding of romantic writers, is the greatest epic poem of ancient India. " $\mathrm{Nal}$ ' i Damaianti. Indiiskaia povest', podrazhanie Ruckertu" (1843) is part of the Mahobharato. It is indicative that A. Schlegel had high praise for this poem, which was duly noted by Zhukovskii in a footnote to his translation. 


\section{GENRES}

---, „Основное начертанне Эстетикн"

Московский вестник, IV, 92 (1828).

Объективный, пластике соответствующий род есть Эпическая Поэзия, субъективный, музыке соответствующий род - Лирическая, и Поэзия Поэзии, в которой жизнь в ее силе само-определенной, в ее непосредственном движении и образования является. есть Драма.

. . В В трех родах Поззии - Эпопее, Лире и Драме, жизнь является в трех мгновениях времени; ибо прошедшее, совершенная, уже образованная жизнь, господствует в Эпопее; настоящее, непосредственно для духа и в нем самом условленная жизнь, является в Лирической Поззии, и будущее, из прошедшего и настоящего образующееся и из взаимного их содействия происходящее произведение, господствует в Драме. - высшем единстве Эпопеи и Лиры.

. . . Романтическая Эпопея открывает дух, более идеальный и фантастический в искусственном порядке и связи происшествий, в светлом, то восторженном, то ироническом тоне повествования и в перемешанных рифмах. в стансах. . . .

Если в Лирическом творении движение духа представляется чисто внутреннею, свободною и одушевленною жизнию, вот $O d a$. торжественная песнь, которой в романтической поэзии соответствует канцона: еслижь чувствование заключается более в спокойном созерцанин, тогда рождается Элегия, существо которой есть более Эпическое, в романтической Поззии - Балльада. . .

Когда внутренная жизнь духа предоставляется в боренин со внешним миром, следовательно переходит в поступок, тогда Лирическая Поэзия превращается в Драматическую - в единство Эпической и Лирической (объективной и субъективной). . . .

Трагедия есть чистое борение человеческой свободы с судьбою,

' ее цель и развязка - примирение конечного с бесконечным или горестное уничтожение конечного; Комедия есть представление жизни в ее свободно - бесконечной игре. в ее веселии . Или: Трагедия есть действие важное, горесть жизни. очищение конечного и переход его в истиннобесконечное по уничтожении его мнимой безусловности; и так Трагедия научает, что человек смертию только, т. е. очищением от смертного, может достигнуть истинной, безусловной жизни: Комедия напротив есть игра и радость жизни, которая в высшем, одушевленном расположении возвышается над ограниченностию конечного, и созерцает его 
как простую игру случая; она научает равномерно, что только бесконечное есть безусловная, истинная жизнь, но показывает сие непосредственным образом, не уничтожая конечного как Трагедия, но в нем же самом представляя его существом ничтожным. . . .

Человек является в Трагедии существом идеальным, которое чем более на пути к цели встречает трудностей, тем более испытует свою свободную, нравственную силу. . . .

В новой Трагедии борение свободы с судьбою не представляется настоящею противоположностию, но только в поступке Героя, в его борения с трудностями и в конечной победе оных, или в падения Героя означается. . . .

Распространенная басня или увеличенная сказка есть Роман, в котором соединяются вдохновение и поучение; ибо изображенные действия, происшествия и перемены судьбы - в одном лище частном - представляют зеркало жизни человеческой вообще.

The joumal Moskovskii vestnik (1827-1830), founded by the Moscow circle of liubomudry (Venevitinov, Khomiakov, Pogodin, Shevyrev, 1. V. and P. V. Kireevskii, et al.), and edited by M. P. Pogodin, spread romantic views based on German idealistic and romantic philosophy, especially during the first two years of its existence.

Many romantic writers considered music the most romantic art of all (ef., Wackenroder, Schopenhauer, and E. T. A. Hoffmann, or V. F. Odoevskii), since it was considered to partake of the lyrical element (Zhukovskii had said already, "iskusstvo-poeziia $v$ raznykh formakh'). Concerning drama, refer to August Schlegel and his Lectures on Dramatic Art and Literoture (1808; published 1809-11).

Friedrich Schlegel had defined romantic literature as "a progressive universal poetry" (Athenäum. 1800) meaning that poetry would progressively unite the various kinds and genres of art into one.

The elements of the plastic (sculpture), the picturesque (painting), and the musical (music) became integrated with literature. All arts and all genres merged in poetry (Schelling).

The definition of the trogic above is an almost literal rendition of Schelling's definition (cf. "About Tragedy," in Philosophie der Kunst, part II, sect. 4/2 [1859], p. $337 \mathrm{fr}$. . See also "Second Lecture" of A. Schlegel's Lectures on Dramatic Art and Literature.

1833 Бестужев-Марлинския, „О романе Н. Полевого, ,Клятва при гробе Господнем" "

Московский телеграф, XV - XVIII (1833).

Я скажу вам, что, по-моему, первобытная поэзия народов непременно зависит от климата. . . .

. . В Вторая, несомненная степень поззии есть эпопея, то есть на-

родные предания о старине, одеты в шумиху баски. Да, история всех племен всегда начинается баснею. . . .

. . . Видя, что народ не верит уже сказкам, эпопея перекидывается 
в драму. Она требует от истории какое-нибудь частное происшествие и переливает его в сою огромную форму; выхватывает из толпы царей несколько имен, отмеченных природою или молвою, и путает их в невидимые цепи судьбы, бросает им молнию роковых страстей в грудь, растит эти страсти до великанских размеров, заставляет совершать страшные злодейства и потом, неумолимый судия, бичует преступника змеями фурий, рассекает его огненным мечом своим пополам и показывает его сердце наголо зрителям, безмолвным от ужаса, - сердще, на котором вы видите еще зубы совести, которое плачет кровью, которое трепещется от мучений. Такова была трагедия древних, трагедия Эсхила, Софокла и Эврипида.

. . . Напротив, комедия принадлежала собственно народу, ибо она изображала народ в домашнем быту, нараспашку, народ вольный однако $ж$, народ царя наязнанку, народ, который, зашивая дыры на тунике, толковал, как разбить Ксеркса или Югурту.

... Наконец за драмою возникает роман и потом идет об руку с драмою - роман, который есть не что иное, как позма и драма, лиризм и философия и вся поззия в тысяче граней своих, весь свой век на обе корки. Древние не знали романа, ибо роман есть разложение души. история сердаа, а им некогда было заниматься подобным анализом; они так были заняты физическою и политическою деятельностию, что нравственные отвлеченности мало имели у них места. . . .

В полдюжины лет нажили мы не одну дюжину романов, подснежных. пудовых романов, романов, в которых есть и русский квас и русский хмель; есть прибаутки, и пословищы, от которых не отказался бы ни один десятский: есть и лубочные картинки нашего быта, раскрашенные матушкой грязью; есть в них все, кроме русского духа, все, кроме русского народа! Со всем тем почтеннейшая толпа земляков моих верит, что она покупает мумию русской старины во французской обвертке, с готическими виньетками, с картинками, резанными в Вене; верит, что эти романы - ее предки или современники; верит с тупоумием старика или с простоумием ребенка и целуется с этими куклами-самоделками; покупает не накупится; читает не нахвалится.

See above, p. 44.

Eskhil-Aeschylos; Sofokl-Sophocles; Evripid-Euripides; Kserks-Xerxes; lugurtaJugurtha, Vena-Vienna.

Bestuzhev-Marlinskii reflects the romantic understanding of Greek civilization as reflected in ancient Greek tragedies. Like the German romantics, he defined the novel as the central genre of literature. Friedrich Schlegel said of the novel that it was an encyclopedia of the entire spiritual life of an individual of genius /Critical Fragments. no. 78). 
1841 В. Г. Белинскиһ, „Разделение поэзин на роды и вцды” Отечественные записки, XV, 3 (1841).

Здесь не видно поэта; мир, пластически определенный, развивается сам собою, и поэт является только как бы простым повествователем того, что совершилось само собою. Это поэзия эпическая.

... Это царство субъективности, это мир внутренний, мир начинаний, остающийся в себе и не выходящий наружу. Здесь поэзия остается в элементе внутреннего, в ощущающей, мыслящей думе; дух уходит здесь из внешней реальности в самого себя и дает поэзия различные до бесконечности переливы и оттенки своей внутренней жизни, которая претворяет в себя все внешвее. Здесь личность поэта является на первом плане, и мы не иначе, как через нее, все принимаем и понимаем. Это поэзия лирическая.

... Внутреннее перестает оставаться в себе и выходит вовне, обнаруживается в действии; внутреннее, идеальное (субъективное) становится внешним, реальным (объективным). Как в эпической поэзии, здесь также развивается определенное, реальное действие, выходящее из различных субъективных и объективных сил. ... Это высшая поэзия и венец искусства - поззия драматическая.

В драме сила и важность события дает себе знать, как „коллизия”, или та сшибка, то столкновение между естественным влечением сердца героя и его понятием о долге, которые не зависят от его воли, которых он не может ни произвесть, ни предотвратить, но которых разрешение зависит не от события, но единственно от свободной воли героя. Власть события становит героя драмы на распутии и приводит его в необходимость избрать один из двух, совершенно противоположных друг другу путей для выхода из борьбы с самим собою; но решение в выборе пути зависит от героя драмы, а не от события. . . .

Несмотря на то что в драме, как и в эпопее, есть событие, драма и эпопея диаметрально противоположны друг другу по своей сушности. В эпопее господствует событие, в драме - человек. Герой эпоса происшествие; герой драмы - личность человеческая. . . .

Эпос есть первый зрелый плод в сфере поэзки только что пробудившегося сознания народа. Эпопея может явиться только во времена младенчества народа, когда его жизнь еще не распалась на две противоположные стороны - поэзию и прозу, когда его история есть еще только предание, когда его понятия о мире суть еще религиозные представления, когда его сила, мощь и свежая деятельность проявляется только в героических подвигах. . . .

Лучшие попытки в эпопее у новейших народов - без сомнения, „Освобожденный Иерусалим", „Потерянный рай” и „Мессиада”. . . .

Эпопея нашего времени есть роман. В романе - все родовые и 
существенные признаки эпоса, с тою только разницею, что в романе господствуют иные элементы и иной колорит. Здесь уже не мифические размеры героической жизни, не колоссальные фигуры героев. здесь не действуют боги, но здесь идеализируются и подводятся под общий тип явления обыкновенной прозвической жизни. Роман может брать для своего содержания или историческое событие и в его сфере развить какое-нибудь частное событие, как и в эпосе: различие заключается в характере самых этих событий, а следоввтельно, и в характере развития и изображения; или роман может брать жизнь в ее положительной действительности, в ее настоящем состоянин. Это вообще право новейшего искусства, где судьбы частного человека важны не столько по отношению его к обществу, сколько к человечеству.

. . . Задача романа, как художественного произведения, есть совлечь все случайное с ежедневной жизни и с исторических событий, проникнуть до их сокровенного сердца - до животворной идеи, сделать сосудом духа и разума внешнее и разрозненное. От глубины основной идеи и от склы, с которою она организуется в отдельных особностях, зависит ббльшая или меньшая художественность романа. Исполнением своей задачи роман становится на ряду со всеми другими произведениями свободной фантазии. . . .

Повесть есть тот же роман, только в меньшем объеме, который условливается сущностию и объемом самого содержания. В нашей литературе этот вид романа имеет представителем истинного художника - Гоголя. . . .

. . . Все, что занимает, волнует, радует, печалит, услаждает, мучит, успокоивает, тревожит, словом, все, что составляет содержание духовной жизни субъекта, все, что входит в него, возникает в нем, - все это приемлется лирикою, как законное ее достояние. Предмет здесь не имеет цены сам по себе, но все зависит от того, какое значение дает ему субъект, все зависит от того веяния, того духа, которым проникается предмет фантазиею и ошушением.

. . . Наконец, субъект, кроме этих совершенно личных ощущений, выражает в лирических произведениях более общие, более сознательные факты своей жизни, различные созерцания, воззрения, сближения, мысли, весь объективный запас сведений и пр. Сюда, кроме собственно пески, относятся сонеты, стансы, канцоны, злегии, послания, сатиры и, наконец, все те многоразличные стихотворения, которые трудно даже и назвать особенным именем. Все они, вместе с песнею, составляют исключительную лирику нашего времени. Лучшие, задушевнейшие создания лирической музы Пушкина принадлежат к числу их. . . .

Элегия собственно есть песня грустного содержания; но в нашей литературе, по преданию от Батюшкова, написавшего „У мирающего Тасса", возник особый род исторической. или зпической. элегии. Поэт 
вводит здесь даже событие под формою воспомннания, проникнутого грустью.

. . . В балладе поэт берет какое-нибудь фантастическое и народное предание или сам изобретает событие в этом роде. Но в ней главное не событие, а ощущение, которое оно возбуждает, дума, на которую оно наводит читателя. Баллада и романс возникли в средние века, и потому герои европейских баллад - рыцари, дамы, монахи; содержание явления духов, такнственные силы подземногамира; сцена - замок, монастырь, кладбище, темный лес, поле битвы.

. . . Романс отличается от баллады решительным преобладанием лирического зпемента над эпическим, а вследствие этого и гораздо меньшим объемом. Жуковский познакомил нас свонми позтическими переводами и с этим родом лирической поэзии. . . .

Драматическая поэзия есть высшая ступень развития поэзии и венец искусства, а трагедия есть высшая ступень и венец драматической поззии. Посему трагедия заключает в себе всю сушность драматической поззии, объемлет собою все элементы ее, и, следовательно, в нее по праву входит и элемент комический. Поззия и проза ходят об руку в жизни человеческой, а предмет трагедии есть жизнь во всей многосложности ее элементов. . . .

Комедия есть последний вид драматической поэзии, диаметрально противоположный трагедии. Содержание трагедии - мир великих нравственных явлений, герои ее - личности, полные субстанциальных сил духовной человеческой природы; содержание комедии - случайности, лишенные разумной необходимости, мир призраков или кажущейся, но не существующей на самом деле действительности; герои комедии люди, отрешившиеся от субстанщиальных основ своей духовной натуры. Посему действие, производимое трагедиею, - потрясающий душу священный ужас; действие, производимое комедиею, - смех, то веселый то сардонический. Сущность комедии - противоречие явлений жизни с сущностию и назначением жизни. В эгом смысле жизнь является в комедии как отрицание самой себя. Как трагедия сосредоточивает в тесном круге своего действия только высокие, поэтические момевты в событии героя, так комедия изображает преимущественно прозу повседневной жизни, ее мелочн и случайности. . . .

Есть еще особый вид драматической поэзия, занимающий середину между трагедиею и комедиею: это то, что называется собственно драмою. Драма ведет начало свое от мелодрамы, которая в прошлом веке делала оппозищию надутой и неестественной тогдашней трагедии в которой жизнь находила себе единственное убежнще от мертвящего псевдоклассицизма. 
1844 Н. В. Гоголь, „Учебная книта словесности для русского юношества" 1845 Сочинения Гоголя, VI, 10-ое изд. (Москва-Санкт-Петербург, 1889-1896).

\section{О поэзии лирической}

Поззия лирическая есть портрет, отражение и зеркало собственных высших движений души поэта, его самонужнейшие заметки, биография его восторгновений. . . . Словом, она есть чистая личность самого поэта и чистая правда. ... .

\section{Oды. гимны и лирические воззвания}

Ода есть высочайшее, величественнейшее, полнейшее и стройнейшее из всех позтических созданий. Ее предметом может послужить только одно высокое: ибо одно высокое может только внушить душе то лирическое. торжественное настроение души, какое для нее нужно и без какого не произвесть оды поэту, как бы велик он ни был. Посему и предмет од или сам источник всего - Бог или то, что слишком близко высотою чувств своих к божественному. . . .

... Она не летит вверх, как гимн, но как бы пребывает все на равной высоте, паря, а не улетая. И потому всегда в равносильных и равномерных строфах и при свободе своей сохраняет в себе строгий порядок. Гимн не имеет тех качеств. Он есть первое излияние чувств. которые просятся из души в наружу. Он беспорядочен, как самые сильно возбужденные в нас чувства, которые стремятся только поскорей выразиться, не думая о том, откуда и с чего приличнее начать; и начинается он и оканчивается, где ему вздумается, имея вожатым одно вдохновение, которое внушило поэту на ту пору обнявшее его чувство....

\section{Песня}

Песня составляет самый богатейший отдел поззии у народов славянских. Преобладание поэтического элемента в глубине славянской души и особенное мелодическое расположение нашего языка были причиною происхождения бесчисленного множества песен в нашей словесности. которые уже и вдревле, когда слова не записывались и словесность, не переходя в письменность, оставалась в буквальном смысле словесностью. составляли наше достояние. . . .

Песня обнимает все: все чувства и ощущения жизни, и потому может делиться на множество разных родов; может изображать уединение, внутренние движения и поэтические мечты поэта, может выражать страсть и любовь, может быть застольной и выражать веселье души и грусть; может изображать картину или состояние другого, как в 
романсе, переходя от дифирамба до тихой элегической задумчивости. Словом, все, что ни приводит к настроенному состоянию дух, есть уже ее предмет, хотя это.не есть та величавая, высокая восторженность, как в оде, возвышенная уже самым величием взятого предмета. . . .

Сочнняющвй песню должен как бы слышать в то же время ее внутреннюю музыку, дающую тайный размер и стихам и строфам. Лучшие песни сочинялись в самую минуту пляски, пиршества и вызывались ударом смычка, свистом волынки, звоном стаканов, мерным ударом стоп. От этого они получают то невыразимо-мелодическое свойство звуков, составляющее такую прелесть в песнях народных. . . .

\section{Enezus}

Елегия есть как бы покойное изложение чувств, постоянно в нас пребывающих, не тех великих и сильных, которые пробуждаются в нас мгновенно при воззрении на предметы великие, не тех, которые, подобно святыне, сохранно пребывая в глубине души, стремят на великие подвиги человека, - но тихих, более ежедневных, более дружных с обыкновенным состоянием человека. Это сердечная история-то же, что дружеское откровенное письмо, в котором выказываются сами собою излучнны и состояния внутренние души. . . .

Чаще всего носит она одежду меланхолическую, чаще всего в ней слышатся жалобы, потому что обыкновенно в такие минуты ищет сердце высказаться и бывает говорливо.

\section{Дума}

Дума есть род стихотворений, не заимствованный ниоткуда, но образовавшийся у славян. Песни северных конунгов имеют в ней некоторое сходство. Она не есть баллада, которой содержанием избираются таинственные поэтические предания, неясные, шевелящие и пугающие воображение явления. В ней ничего нет такого, что бы было необъясненно, неопределенно и заманивало бы самой поэтической своею неопределенностью. Напротив, в ней все определенно и ясно. Ее предмет - происшествие истинно историческое, действительно бывшее, или же предание, так живо хранящееся в народе, что сама история внесла его в свои странищы. Думы могут быть только об одних исторических лицах. . . .

\section{Поэзия повествовательная или драматическая}

Поэзия повествовательная, В противоположность лирической, есть живое изображение красоты предметов, движения мыслей и чувств вне самого себя, отдельно от своей личности, до такой степени, что чем более автор умеет отделиться от самого себя и скрыться сам за лицами, 
им выведенным, тем больше успевает он и становится сильней и живей В этой поззии; . . .

Значительность поэзии повествовательной или драматической увеличивается помере тото, как позт стремится доказать какую-нибудь мысль и, чтобы развить эту мысль, призывает в действие живые лица, из которых каждое своей правдивостью и верным сколком с природы увлекает вниманье читателя и, разыгривая роль свою, ему данную автором, служит к доказатөльству его мысли. По мере того, чем совершается это естественней, и все происшествие кажется живым, естественным случаем, недавно случнвшимся, - между тем как внутренно двигнуто глубоким логическим выводом ума. Тогда сочинение живое, драматическое и кипящее пред очами всех, становится с тем вместе в высшей степени дидактическое и есть верх творчества, доступного одним только великим гениям. . . .

\section{Эnones}

Величайшее, полнейшее, огромнейшее и многостороннейшее из всех созданий драматическо-повествовательных есть эпопея. Она избирает в герое всегда лицо значительное, которое было в связях, в отношениях и в соприкосновении со множеством людей, событий и явлений, вокруг которого необходимо должен созидаться весь век и его время, в которое он жил. Эпопея объемлет не некоторые черты, но всю эпоху времени, среди которого действовал герой с образом мыслей, верований и даже познаний, какие сделало в то время человечество. Весь мир на великое пространство освешается вокруг самого героя. и не одно частное лищо. но весь народ, а часто и многие народы совокупляются в эпопею, оживают на миги, восстают точно в таком виде перед читателем, в каком представляет только намеки и догадки история. . . .

\section{Роман}

Роман, несмотря на то, что в прозе, но может быть высоким позтическим созданием. Роман не есть эпопея. Его скорей можно назвать драмой. Подобно драме, он есть сочинение слишком условленное. Ои заключает также в себе строго и умно обдуманную завязку. . . .

. . . Все, что ни является, является потому только, что связано слишком с судьбой самого героя. Здесь, как в драме, допускается одно только слишком тесное соединение между собою лиц. . . .

.. . Роман не берет всю жизнь, но замечательное происшествие в жизни, такое, которое заставило обнаружиться в блестящем виде жизнь, несмотря на условленное пространство. 


\section{Повесть}

Повесть избирает своим предметом случаи, действительно бывшие или могушие случиться со всяким человеком, случай почему-нибудь замечательный в отношении психологическом, иногда даже вовсе без желания сказать нравоучение, но только остановить внимание мыслящего или наблюдателя. Повесть разнообразится чрезвычайно. Она может быть даже совершенно поэтическою и получает название поэмы, если происшествие, случившееся само по себе, имеет что-то поэтическое. . . .

Иногда даже само происшествие не стоит внимания и берется только для того, чтобы выставить какую-нибудь отдельную картину, живую, характеристическую черту условного времени, места и нравов, а иногда и собственной фантазии поэта.

\section{Сказка}

Сказка может быть созданием высоким, когда служит аллегорическою одеждою, облекающею высокую духовную истину, когда обнаруживает ощутительно и видимо даже простолюдину дело, доступное только мудрецу. . . . Наконец сказка может быть созданье значительное, когда содержание хотя создано все поэтом, но в духе народном оттаданы дух и время. . . .

The Uchebnaia kniga. . . was not completed by Gogol. The original intention of the author had been to write a major work in two volumes. Part II (chast' prozaicheskaia) and the chapters on drama, tragedy, and comedy are lacking. The completed sections were first published between 1889 and 1896. 


\section{POETRY}

1801 Андрей Тургенев, „Речь о русской литературе” Русский библиофил, 1 (1912).

Теперь только в одних сказках и песнях находим мы остатки русской литературы, в сих-то драгоценных остатках, а особливо в песнях находим мы и чувствуем еще характер нашего народа. Они так сильны, так выразительны в веселом ли то или в печальном роде, что над всяким непременно должны произвести свое действие. В большей части из них, особливо в печальных, встречается такая пленяющая унылость, такие красоты чувства, которых тщетно стали бы искать мы в новейших подражательных произведениях нашей литературы. Но трудно уже переменить то, чего кажется никто и не подозревает.

Russian folksongs had been collected and published in the 18 th century by N. L'vov, Sobranie narodnykh pesen s ikh golosami. Na muzyku polozhil Ivan Prach' (SanktPeterburg. 1790; 2nd ed. 1806. 3rd ed. 1815). Mikhail Chulkov had published songs in 1770-1774. Matvei Komarov's Obstoiatel'noe i vernoe opisanie dobrykh $i$ zlykh del rossiiskogo moshennika. . . Van'ki Kaina. . . (Moskva. 1779) contained 47 folksongs. Mikhail Popor published a collection of songs, Rossiiskaia Erata. in St. Petersburg in 1792. The interest in folklore was furthered by the discovery (1795) of the Song of Igor's Campaign (Slovo o polku Igoreve, going back to the 12 th century) by Count Musin-Pushkin. The song was published in 1800 . Another influential collection, Kirsha Danilov's Dreinie russkie stikhotvoreniia, appeared in 1804.

1808 А. Ф. Мерзляков, Слово о духе. отличительных свойствах поззии первобытной и о влиянии, какое имела она на нравы, на благосостояние народ. Oв (Москва, 1808).

Собирая древности чуждые, не хотим заняться теми памятниками, которые оставияи знаменитые предки наши! В русских песнях мы бы увидели русские нравы и чувства, русскую правду, русскую доблесть! В них бы полюбили себя снова и не постыдились так называемого первобытного своего варварства. Но песни наши время от времени теряются, смешиваются, искажаются и, наконец, совсем уступят блестящим безделкам иноземных трубадуров. Неужели не увидим ничего более, подобного несравненной песне Игорю!

Pesnia Igoriu-Song of Igor's Campaign (see above). 
В. А. Жуковския,, „О нравственной пољъзе поэзни"

Вестник Европы, XL, 3 (1809).

. . . Шоззия действует на одни зстетические силы нашей души - следственно, и ее теория должна иметь отношение к одним только эстетическим силам. Вредмет поэзии - чувственное совершенство, следовательно, и предметом ее теории должно быть сие же самое чувственное совершенство, изображаемое посредством языка, единственного орудия стихотворцев.

Стихотворное искусство имеет в виду одно изящное, действует исключительно на одно чувство, остается довольным, если недостаток морально прекрасного не обратится в совершенное моральное безобразие.

1809 В. А. Жуковский, „О басне и баснях Крылова” Вестник Европы, 9 (1809).

Что в наше время называется баснею? Стихотворный рассказ происшествия, в котором действующими лицами обыкновенно бывают или животные, или твари неодушевленные. Цель сего рассказа - впечатление в уме какой-нибудь нравственной истины, заимствуемой из общежития и, следовательно, более или менее полезной. . . .

В истории басни можно заметить три главные эпохи: первая, когда она была не иное что, как простой риторический способ, пример, сравнение; вторая, когда получила бытие отдельное и сделалась одним из действительнейших способов предложения моральной истины для оратора или философа нравственного, - таковы басни, известные нам под именем Эзоповых, Федровых и в наше время Лессинговых; третья, когда из области красноречия перешла она в область поззии, то есть получила ту форму, которой обязана в наше время Лафонтену и его подражателям, а в древности Горацию.

. . . - Баснописец-поэт составляет один фантастический мир из двух существенных: в одном из сих последних заимствует он характеры, свойства моральные и самое действие, в другом одни только лица. Чего же я от него требую? Чтобы он пленял мое воображение верным изображением лиц; чтобы он своим рассказом принудил меня принимать в них живое участие; чтобы овладел и вниманием моим и чувством, заставлял их действовать согласно с моральными свойствами, им данными; чтобы волшебством поззии увлек меня вместе с собою в тот мысленный мир, который создан его воображением, и сделал на время, так сказать, согражданином его обитателей; в чтобы, наконец, удовлетворил рассудку моему какою-нибудь моральною истиною, которое не иное что, как цель, к которой привел он меня стезею цветушею. 
Таковы басни стихотворцев новейших, и в особенности Лафонтеновы.

Basni Ezopovye, Fedrovye. Lessingovye-fables by Aesop (6th century B.C.), Phaedrus (approx. 15 B.C.), and G. E. Lessing (1729-1781). La Fonten-Jean de Lafontaine (1621-1695), author of fables. Goratsii-Horace.

1810 В. А. Жуковскй̆, „О сатире и стихах Кантемнра” Вестник Европь, 3, 6 (1810).

Какой предмет сатиры? Осмеяние человеческих заблуждений, глупостей и пороков. Смех производит веселость, а веселость почитается одним из счастливейших состояний человеческого духа. Во всех нам известных языках, говорит Адиссон, находим метафору: поля смеются. луга смеются; это служит доказательством, что смех сам по себе есть что-то привлекательное и любезное. Смех оживляет душу, или рассевая мрачность ее, когда она обременяема печалию, или возбуждая в ней деятельность и силу, когда она утомлена умственною, трудною работою. . . .

Философы и позты употребляют оружие насмешки для пользы нравов. Сатирик и комик имеют то сходство с моралистом-философом. что они действуют для одной цели, которой, однако, достигают различными путями. Моралист рассуждает и, убеждая ум. говорит сердцу: напротив, комик и сатирик осмеивают моральное безобразне и тем более привязывают нас к красоте моральной, которая становится ощутительнее от противоположности. Различие между сатирою и комедиею заключается в одной только форме: в комедии мы видим перед глазами те оригиналы и те пороки, которые сатирик представляет одному только вообрахению; там они сами выходят на сцену и сами себя обіичают: и здесь выходит на сцену позт, который или забавляет нас своими колкими шутками, или производит в душе нашей благодетельное негодование. Из всего сказанного выше можно легко составить себе понятие о характере сатирического стихотворца и комика. Они необходимо должны иметь дух наблюдательный, глубокое знание человеческого сердца и редким известное искусство представлять в смешном все то, что не согласно с правилами и понятиями чистой морали. Искусство осмеивать остроумно тогда только бывает истинно полезным, когда оно соединено с высокостию чувств, неиспорченным сердщем и твердым уважением обязанностей человека и гражданина. Истинный сатирик и стихотворец комический должны ненавидеть изображаемые имн пороки.

Сатира должна быть сатирою, снедовательно, иметь собственную, ей одной принадлежащую форму. Сатирик, можно сказать, заимствует 
эту форму у философа; но он заимствует как стихотворец и сверх того пользуется некоторыми особенными способами. Избравши предмет свой, он применяется к нему тоном, слогом и расположеннем; например: нападая на странности, он вооружается легкою и колкою шуткою, смешнт и исцеляет приятным лекарством смеха; напротив, имея в виду какой-ннбуды вредный, заразительный порок, он возвышает тон, выражается с жаром, и тогда самая насмешка его принимает на себя наружность негодования.

Теперь скажем несколько слов о тех̄ предметах, которымн всего приличнее заниматься сатирику. Он доджен из бесчисленного множества пороков, странностей и заблуждений выбирать только такие, которых влияние и общее и самое обширное; частные заблуждения и пороки, будучи малозаметны, потому именно и не могуг быть заразительны: ибо они пронсходят по большей части от некоторых особенных недостатков ума и характера, которые надлежит почитать исключениями. Личность есть тоже, что низкое мщение; она уничтожает нашу доверенность к сатирику, который в глазах наших должен быть проповедником истины и добрых нравов. Один человек не может быть образцом для других ни в добре, ни в зле: стихотворец изображает нам только то, что свойственно всему человечеству, соблюдая, однако, все те отличия, которые человеческая натура заимствует от нравов и обычаев его века, - следовательно, будучи наблюдателем тонким, он должен изображать человека вообще, то есть представлять нам в добродетелях и в пороках идеал целого, составленный из множества мелких, в разное время замеченных им частей - таковы должны быть нравственные картины сатирика.

Addison-Joseph Addison (1672-1719), English poet, essayist, statesman, published moralistic weeklies (Tatler, Spectator). Zhukovskii's definition of satire reflects the late sentimental concept of this genre. Note the emphasis on abstract types and the improvement of morals.

1811 Г. Р. Державин, „Рассужденне о лирической поэзин итн 06 оде” Чтекие в Беседе любителей русского слова. II (1811); VI (1812); XLV (1815).

С сего времени разлился свет новейшей поэзии, появившейся сначала от арабских, испанских и сищилийских границ и час от часу потом более распространявшейся и процветавшей. В исходе того же столетия В Италии восстали самые славные позты: Данте, Петрарк, и Бокаций. Они, подражая древним, образовали свои лирические произведения по их примерам и могут беспрекословно назваться 
возродителями древней и отцами новой поззии в так ими названных канцонах, сонетах, балладах, стансах, мадригалах и других песнях, известньх в Европе. . . .

Ода, слово греческое, равно как и псальм, знаменует на нашем языке песнь. По некоторым отличиям в древности носила на себе имя гимна, пеана, дифирамба, сколии, а в новейших временах иногда она тоже, что кантата, оратория, романс, баллада, станс и даже простая песня. . . . По лире . . . называется ода лирическою поззиею. . . .

Все его (поэта) окружающее: солнце, луна, моря, горы, леса и реки наполняли живым чувством и исторгали его гласы. Вот истинный источник оды; . . . Она не наука, но огнь, жар, чувство.

Derzhavin reflects the romantic view of the origin of "modern" literature in the South of Europe (see above, p. 127). The ode, which had already lost much of its cumbersome classicist conventionality in the poetry of Kheraskov and Murav'ev in the late 18 th century, changed further in Derzhavin's work and became an exalted lyrical poem. Dante Alighieri (1265-1321); Petrark - Francesco Petrarca (1 304-1374); BokatsiiGiovanni Boccaccio (1 313-1375).

1812 А. Х. Востоков, „Отыт о русском стихосложеняи” Санкт-Петербургский вестник (1812).

. . . Сказочный русский стих, будучи сам по себе разнообразнее песенных, был бы удобнее для поэмы, - не для героической, конечно, а для романической. во вкусе Ариоста либо Виланда. Так и песенные размеры не для всякого лирического стихотворения пригодны: никто, конечно, не вздумает написать ими оду или кантату. Главная сему причина может быть та, что русские размеры вообще по своему дактилическому трибрахическому строению слишком игривы для важных предметов; или же что они, доселе быв представлены только простонародной поззией, следовательно, предметом низким и ограниченным, чрез то самое лишены стали в глазах наших и благородства и возвышения. Желательно, чтобы люди с талантом попытались истребить в нас сей предрассудок, если только можно, облагородствовав и возвысив русский размер стихами своими; или бы доказали, что стихосложение русское по несовершенству своему не заслуживает извлечено быть из праха, в каком оно до селе пресмыкалось.

A. Kh. Vostokov (1781-1864), a member of the Free Society and a poet of note during the first decade of the 19th century, became one of the first Russian scholars in Slavic studies (cf. his Rassuzhdenie o slavianskom iazyke, 1820). His interest in Slavic folklore is evident in his own poetry (e.g., Svetlana $i$ Mstislav, bogatyrskaia povest', Bogemskie pesni) as well as in the above study of Russian versification which was one of the first investigations of Russian tonal versification. Pushkin said of Vostokov's work: 
„Много говорили о настоящем русском стихе. А. Х. Востоков определил его с большою ученостыю и сметливостыо. Вероятно, будущия наш эпическия поэт изберет его и сделает народным" (А. С. Пушкин, Полное собрание сочикений. XI [1949], stp. 263).

1813 А. Ф. Мерзляков, „Об изяшном, или о выборе в подражанин" Вестник Европы, III (1813).

В поэме поэт обнимает небо, землю и ад. Поэма его представляет маленькую вселенную, а сам поэт кажется творцом своего мира.

1813 С. С. Уваров, [Письмо Гнеднчу от 1813 г. ] Сочинения Гнедича, I (Москва, 1884).

Одна из величайших красот греческой поззия есть богатое и систематическое ее стопосложение. Тут каждый род поззии имеет свой размер; и каждый род не только свои законы и правила, но, так сказать, свой гений и свой язык. Гексаметр предоставлен эпопее. Этот размер весьма способен к сему роду поэзия.При величайшей ясности, он имеет удивительное изобилие в оборотах, важную и пленительную гармонию. Французы, по необходимости, должны были, всдедствие неподатливости своего языка, изобрести другую систему стихосложения. Но возможно-ли узнать гекзаметр Гомера, когда, сжавши его в александрийский стих и оставляя одну мысль, вы отбрасываете размер, обороты, расположение слов, эпитеты, одним словом все, что составляет красоту подлинника? Когда вместо плавного, величественного гекзаметра, я слышу скудный и сухой александрийский стих, рифмой прикрашенный, то мне кажется, что я вижу божественного Ахиллеса во французском платье. . . .

Героический размер украшается совершеннейшим равновесием всех частей стиха: гекзаметр не подымается и не падает; он изгибается, течет тихо, но без прыжков; свободно, но в строгих границах. - Ему предоставлено обращаться от быстроты к медленности, от силы к мягкости; и все оттенки между сими противоположностями заключенные, вмещаются в стопосложнении гекзаметра.

Gnedich began to translate the lliad in Alexandrines, yet was dissatisfied. In 1813 a polemic began on the pages of Chtenie $\nu$ besede liubitelei slovesnosti conceming the possibility of the hexameter in Russian poetry. S. S. Uvarov advocated the use of this metre. Gnedich responded with a letter in which he described the hexameter as the only possible metre for the liad. Uvarov answered Gnedich with the above lines. More than a decade later, a minor critic, Dubenskii, published an essay, "O vsekh upotrebliaemykh $\vee$ Russkom iazyke stikhotvornykh razmerov" (Atenei, 13-16, 1828), in which he gave this summary: 
„Гораздо с бо́льшим успехом обработали сея размер Гг. Воеиков и Гнедич, особливо последния. Но совету С. С. Уварова, он начал переводить с Греческого Омкрову Илиаду размером подлинника. Первые опыты сего преложения, напечатанные в 13-ой книжке Чтекия в беседе, приняты весьма благосклонно. Прекрасные переводы и сочннения Жуковского, писанные экзаметрами. как-то: Овсякой кисель, Красный карбуккул. отрывки из Энеиды. из Клопштоковой Мессиады, из Превращений Овидиевых и проч.; послание Г. Воеикова к Уварову об экзаметрах, его переводы и Мерзлякова из Георгик, сказка Ф. Глинки, Бедносто и труд. кажется навсегда усвонли сей размер нашему языку."

$1815--,$, ,06 оде"

Сын отечества, XX(1815).

Человек поет только тогда, когда страсть управляет его сердщем. и потому лирические стихи суть излияние чувствительности. - Все что трогает душу и восвышает выше ее самой; все, что производит в ней впечатление нежное, сладостное; одним словом, все чусвтвования, которые она принимает и любит изливать - причнны оде.

Она не отличается от прочих родов поэзия своими предметами, ибо объемлет бесчисленное множество разных предметов. Единственное различие, которое можно сделать между ею и другими позмами, состоит В том, что в сих последних часто находим повествование о действиях. а ода всегда выражает чувство. . . . Ода будучи живым, пламенным излиянием сердца, пораженного каким-нибудь предметом, не может быть продолжительна: восторг, составляющий существенную часть ее, исчезает скоро. Вот почему длинная ода есть самое скучное и самое утомительное сочинение. . . .

Все оды могут быть разделены на четыре разряда. К первому прннадлежат оды духовные или гимны, воспеваемые Божеству: к второму героические, в которых прославляются воинские подвиги и великие дела: таковы оды Пиндары и некоторые Горация. Отличительные свойства сих двух разрядов величие и возвышенность слога. К третьему относятся оды нравственные или философические, посвященные прославлению добродетелей: таковы большая часть од Горациевских и многие произведения новейших лириков. В них представляются нравственные истины и правила, облеченные прелестями поззии; они богатее мыслями, чем описаниями и чувствами, и восторг их несколько спокойнее восторга оды духовной и героической. К четвертому разряду можно причислить те, в которых воспевается веселие и любовь: таковы оды Анакреона, некоторые из Горащиевых и многие песни новейших 
поэтов. Простота, нежность и веселость составляют свойство их.

Мы находим много лирических поэм в Ветхом Завете. Кроме гимнов и песней, рассеянныХ в книгах Бытия и Пророков, целая книга Псалмов может почитаться собранием Духовньх Од, в которых священный Песнопевец, исполненый духа Божня, объемлет не только чудеса природы, но представляет себе руку Творца, извлекающую из сокровищ его могушества всю вселенную, располагающую и повелевающую всем с бесконечною силою и премудростию. . .

Ломоносов, отец Российской Словесности, первый представил нам образщы лирической поэзии, и может стоять на ряду с величайшими лириками всех народов.

Он совершенно постиг свойство оды, и оставил нам истинные образщы вдохновения. Смелость выражений и великолепие слога суть отличительные черты его поззии. . . .

Наконец явился лирик [Державин], творениями которого должны мы гордиться, как лучшим произведением нашей поэзия. . . .

Мы находим в нем, смотря по предметам его, всю выспренность и быстроту Пиндара, всю прелестную философию Горашия, всю легкость и сладость Анакреона. Богатство его воображения непостижимо. . . .

Анакреонтические оды его прелестны. Ни один народ не может похвалиться таким поэтом, который бы лучше Державина постиг дух Теосского певца: Державин подражатель и соперник его; сами Хариты внушили ему пленительную свою нежность.

Teosskii pevets-Anacreon (approx. 580 B.C.), Greek poet born at Teos; KharityCharites (graces), Greek goddesses of fertility, beauty, joy, and feminine grace.

1816 К. Н. Батюшков, „Речь о влиянин легкой поззнн на язык” Труды Общества любителей российской словесности при Московском yн-re, VI (1816).

Главные достоинства стихотворного слога суть: движение, сила, ясность. В больших родах читатель, увлеченный описаннем страстей, ослепленный живейшими красками поззии, может забыть недостатка и неровности слога и с жадностью внимает вдохновенному поэту или действующему лицу, им созданному. ... . В легком роде поззия чнтатель требует возможного совершенства, чнстоты выражения, стройности в слоге, гибкости, плавности; он требует истины в чувствах и сохранения строжайшего приличия во всех отношениях; он тотчас делается строгим судьею, ибо внимание его ничем сильно не развлекается. Красивость в слоге здесь нужна необходимо и ничем замениться не может. 
... Так называемый эротический и вообще легкий род поззия воспринял у нас начало со времен.Ломоносова и Сумарокова. Опыты их предшественников были маловажны: язык и общество еще не были образованы. ... .

Все роды хороши, кроме скучного. В словесности все роды приносят пользу языку и образованности.

Batiushkov formulated his fundamental views on poetry in the above speech. Light poetry in his understanding encompassed several genres and was the area in which the process of stylistic refinement took place.

1816 Н.И. Гнедич, „О вольном переводе Бюргеровой баллады Ленора" ” Сын отечества, XXXI, 27 (1816).

Стихотворения г. Жуковского родили и многих поклонников. и многих противников. и подражателей, и соревнователей. Сердечно желаем, чтоб подражатели, которые до сих пор только его передразнивают, произвели что-нибудь подобное Певиу в стане русских воинов или Светлане: но В ожидании этого - и. может быть, напрасном - сколько мы должны перечитать посланий к друзьям, в которых. кроме рифм, ничего не посылается, романсов и песен, которые поет один их сочинитель. а баллад. баллад - чудесных, невероятных. но ужасных! Ах, любезный творец Светланы. за сколько душ ты должен будешь дать отчет? Сколько молодых людей ты соблазнишъ на душегубство! Какой ряд предвижу я убийц и мертвецов, удавленников и утопленников! Какой ряд бледных жертв смерти балладической, и какой смерти! . . .

Пробегая оглавления журналов и находя и в Вестнике Европы стихотворение Ольгу и в Сыне отечества. Ольгу. я спешил познакомиться вдруг с двумя Ольгами, но с первого взгляда увидел, что эти обе Ольги - одна и та же старая знакомая Бюргерова Ленора. Но с нею давно поознакомил нас г. Жуковский? Как! И после Людмилы зга балладная кокетка хочет еще нравиться под новым именем? И является вдруг в обеих столицах? И, верно, в новом наряде, с новыми ирелестямия . . . Людмиіа есть оригинальное русское, прелестное стихотворение, для которого идея взята только из Бюргера.

. . . И вот, наконец. истинные чудеса баллады! Адские духи, черти. ибо что другое разумеет под адскими духами? У Бюргера просто $\mathrm{G}$ eister, духи, и под именем духов мы принимаем и души умерших. Так прнял и г. Жуковский:

Вдруг усопшие толпою

Потянулись из могил. 
Но у г. Переводчика Ольги, c'est le diable qui prèche la morale, черти проповедуют нравственность, сами черти молят Бога о прощении грешной души! Какие добрые у него черти! Каких прекрасных чертей отыскал он для баллады! Vivent les ballades! И после этого будут говорить мне, что баллады не имеют нравственной цели? Читай Ольгу буду я кричать каждому: в ней и черти учат нравственности!

G. perevodchik Ol'gi-P. Katenin. Pushkin summarized the dispute almost two decades later (see p. 35 above). Zhukovskii's rendering of Bürger's ballad was still close to sentimental biterature. Katenin's version, on the other hand, corresponded more to the preromantic spirit as is also indirectly pointed out by Pushkin above.

1818 А. Ф. Мерзляков, „Пнсымо из Снбирн”

Труды общества любителей российской словесности, XI (1818).

Скажите, м. г. баллада имеет ли какие-нибудь для себя правила, так, как всякий другой род, получивший право гражданства в кругу литературы? Мы знаем пределы для оды, для поэмы, для трагедия и для элегин, и даже для баллады, некогда бывшей или такой, как нам показала ее Италия, а потом Испания и Португалия, после французы и, наконец, у нас некоторые из осторожнейших писателей? Теперь, Бог знает что: ни вероятия в содержании, ни начала, ни конца, ни цели, ни худой, ни доброй, - все достокнство в слоге. Слог хорош, но что остается у меня в голове или сердще? . . .

Le Conservateur Impartial заставляет нас торжествовать и радоваться какому-то преобразованию духа нашей поззия. Он поздравляет нас с тем, что мы исполнились духом германских поэтов и что сей дух нам родственный. . . Значит ли изменение, преображение духа всей поэзии одно введение нового рода баллад? И, наконец, что это за дух, который разрушает все правила пиитики, смешивает вместе все роды, комедию с трагедией, песни с сатирой, балладу с одой?

The absence of rules in the structure of the ballad and the tendency to merge genres was unacceptable to Merzliakov, the neoclassicist professor of literature.

Le Consenvateur Impartial, a semi-official newspaper, was published in St. Petersburg (1813-1824). Kiukhel'beker and Grech were printed there. The newspaper maintained a positive attitude to the new romantic movement. As early as 1814 , excerpts of Mme de Stael's famous study of German life and literature appeared there. In 1824, an extensive survey of Byron's life and work appeared on its pages.

Concerning Merzliakov's negative attitude to the spirit (dukh) of German romantic poetry, see also Pushkin's criticism above (pp. 104f.). 
В 1820 r. позма Руслан и Людмила была кончена. Автор спешил оста: вить столицу, где успел наскучить рассеяностию. Жуковский, прощаясь с ним, подарил ему литографированный тогда портрет свой и шутя написал на нем: Ученику-победителью от побемденного учителя в высокоторхественный день окончания Руслана и Людмилы. Много было журнальных толков во время оно о новой поэме. Все они, как ведется В журналах, не касаются существенвого в искусстве. Одни обращены на событие, другие на рифмы, третьи на фразы, четвертые на шутки, и т.д. Никто не заметил, что это была первая на русском языке позма, которую все прочитали, забывши, что до сих пор позма и скука значили у нас одно и то же.

The baffled and indignant reaction of conservative critics to Pushkin's first major work is described in the following two excerpts. The publication of Pushkin's poem is of ten considered to mark the beginning of the romantic movement in Russia.

1820 А. Г. Глаголев, [ Рецензия на „Руслан и Людмнла”] Вестник Европы, CXI (1820).

Возможно ли просвешенному или хоть немного сведушему человеку терпеть когда ему предлагают новую позму, писанную в подражание „Еруслану Лазаревичу”? Извольте же заглянуть в 15 и 16 №№ Сына отечества. Там неизвестный пиит на образчик выставляет нам отрывок из поэмы своей „Людмила и Руслан” (не Еруслан ли?). Не знаю, что будет содержать целая позма, но образчик хоть кого выведет из терпения Пинт оживляет мужичка сам с ноготь, а борода с локоть, придает еще ему бесконечные усы (Сын отечества. стр. 121), показывает нам ведьму, шапочку-невидимку и проч. Но вот что всего драгоценнее: Руслан наезжает в поле на побитую рать, видит богатырскую голову, под которою лежит меч-кладенец; голова с ним разглагольствует, сражается. . Живо помню, как все это, бывало, я слушал от няньки моей; теперь на старости сподобился вновь то же услышать от поэтов нынешнего времени . . . Для большой точности или чтобы лучше выразить всю прелесть старинного нашего песнословия, поэт и в выражениях уподобился Ерусланову рассказчику, например: 
Каково?

.. . Объехал голову кругом
И стал пред носом молчаливо,
Щекотит ноздри копкем . .

Картина, достойная Кирши Данилова! Далее чихнула голова, и с нею и эхо чихает . . . Вот что говорит рыщарь:

Я еду, еду, не свищу,

А как наеду, не спущу ... .

Потом рыцарь ударяет голову в щеку тяжелой рукавицей . . . Но увольте меня от подробного описания, и позвольте спросить: если бы в Московское благородное собрание как-нибудь втерся (предполагаю невозможное возможным) гость с бородою, в армяке, в лаптях и закричал бы зычным голосом: здорово, ребята! - Неужели бы стали таким проказником любоваться! Бога ради, позвольте мне, старику, сказать публике, посредством вашего журнала, чтобы она каждый раз жмуриіа глаза при появлении подобных странностей. Зачем допускать, чтобы nіоские шутки старины снова появились между нами? Шутка грубая, не одобряемая вкусом просвещенным отвратительна, а нимало не смешна и не забавна. Dixi.

Житель Бутырской слободы.

1820 А. Ф. Воеиков, „О поэме Пушкнна Руслан и Людммила' ” Сын отечества, 3437 (1820).

Он любит проговариваться, избясняться двусмысленно, мамекать, если сказать ему не позволено, и кстати и некстати употреблять эпитеты: нагие, полунагие в одной сорочке; у него даже и холмы нагие и сабли нагие. Он беспрестанно томится какими-то желаниями. сладострастными мечтами. во сне и наяву ласкает младые прелести дев; вкушает восторги и проч. Какое несправедливое понятие составят себе наши потомки, если по нескольким грубым картинам, между прелестными 
картинами расставленым, вздумают судить об испорченности вкуса нашего в X IX столетии!. . .

В новейшие времена, всякий почти рассказ, где слог возвышается пред обыкновенным, называется поэмою, хотя прежде сие имя давали только тем пронзведениям, в кокх отисывались геройские подвиги касательно религин, нравственности или таких пронсшествий, которыми решалась судьба царств, где если не заключалось участия целого человечества, то по крайней мере какого-либо народа, и где причины действий сверхъестественны. В Руслане более грубое простонародное волшебство, а не чудесное, которое составляет сущность поэмы. В нем чудеса без правдоподобия, которое есть основание - первый закон поззия. ... Ныне сей род поззии наывается романтическим.

Voeikov repeats an accusation already advanced by Admiral Shishkov in his losing battle with the literary avant-garde-the argument of the immorality of the new literature. See above. pp. 23, 25.

1820 Н. И. Гнедкч, „Сиракузянкн, ити праздник Адониса”

1821 Сочинения Гнедича (Москва, 1884).

Поззия идиллическая у нас, как и в новейших литературах европейских, ограничена тесным определением поэзии пастущеской; определение ложное. Из него истекают и другие, столько же неосновательные мнения, что поэзия пастушеская (т.е. идиллии и эклоги) в словесности нашей существовать не может, ибо у нас нет пастырей, подобных древним, и проч. , и проч. . . . .

В литературах новейших времен, и особенно в италиянской, когда все роды поззии были испытаны, являлось множество идиллий, посреди народа развращенного; но как мало естественности в Санназаро, какая изысканность в Гварини! О французах и говорить нечего. Геснер, которого много читали при двсре Людовика XV, также не мог выдержать испытания времени: он создал природу сантиментальную, на свой образец; пастухов своих идеализировап, а что хуже, в идиллии ввел мифологию греческую. . . .

До сих пор одни позты германские, нам современные, хорошо поняли Феокрита: Фосс, Броннер, Гебель произвели идиллии истиннонародные; пленительные картины оных переносят читателя к той сладостной жизни В недрах природы, от которой нынешнее состояние общества так нас удаляет; они вселяют даже любовь к сему роду жизни. . . .

Германские поэты поняли, что род поззии идиллической, более нежели всякий другой, требует содержаний народных отечественных; что не одни пастухи, но все состояния людей, по роду жизни близких к 
природе, могут быть предметами сей поэзии. Вот главная причина их успеха. ... .

Наши многообрядные свадьбы, наши хороводы, разные игрища, праздники сельские, даже церковные - суть живые идиллии народные, ожидающие своих поэтов.

Sannazaro-J. Sannazaro (1456-1530), poet; Gvarini-Giovanni Bathiste Guarini (15381612), poet and thetorician; Gesner-P. Gessner (1730-1788), Swiss poet; FeokritTheocritos (3rd. cent. B.C.) wrote buccolic poetry; Foss-Johann H. Voss (1751-1826), author of idylls, translator of Homer into German; Bronner-Franz Xaver Bronner (1758-1850), poet; Liudovik XV-Louis XV;Gebel'-Johann-Peter Hebel (1760-1826), German sentimental poet.

1822 П. А Плетнев, „Два антологическне стихотворения" Труды Вольного общества любителей российской словесности, XIX, 17 (1822).

Антологическая поэзия составляет прекраснейшую часть поэзии эпиграмматической, принимаемой в том значении, какое давали ей древние. У них (по словам издателей драгоценной на нашем языке книжки: O Греческой Актологии) каждая небольшая пьеса, размером элегическим писанная, т. е. экзаметром и пентаметром, называлась эпиграммою. Ей все служит предметом: она то поучает, то шутит, и почти всегда дышит любовию. Часто она не что иное, как мгновенная мысль, или быстрое чувство, рожденное красотами природы, или памятниками художества. Иногда греческая зпиграмма полна и совершенна: иногда небрежна и некончена . . . как звук, вдали изчезающий. Она почти никогда не заключается разительною, острою мыслию, и, чем древнее, тем проще. Этот род поэзия украшал и пиры и гробнищы. Напоминая о ничтожности мимоидущей жизни, эпиграмма твердила: смертный, лови миг улетающий! Резвилась с Лаисою - и, улыбаясь кротко и незлобно, слегка уязвляла невежество и глупость. Истинный Протей, она принимает все виды.

"O Grecheskoi Antologij" (published by S. S. Uvarov in 1820) was based on Anthologio Groeca (also known as Anthologia Palotina), a collection of classical and hellenistic poets, compiled originally by Meleagros of Gadara (approx. 80 B.C.), later re-arranged and enlarged. It contains various kinds of epigrams. 

Мнхайла Мнлонова"

Соревнователь просвещения. XVII (1822).

Элегии Милонова (мы в этот разряд помещаем большую часть и посланий его) совершенно отличны от сочинений других наших поэтов в сем же роде. Мы знаем элегии Жуковского и Батюшкова. Первый есть живописец природы и своего воображения, а другой живописец сердща. В элегиях Милонова говорит душевная боль. Он не мечтает, не страдает от любви, а, кажется, от жизни, в которой нет того, чего он искал. Утраты его невозвратимы: потому что он лишился разделения благородных, высоких чувствований и потерял веру в идеальных людей. которых беспрестанно ищут все поэты. От сего в элегиях Милонова встречаются невольные упреки человечеству. Этот род тем ближе был к нему, что он предавался излиянию нежных своих чувствований после сатирического негодования. Голос уньлой души, особенно в лучших местах его элегий, так силен и трогателен, что невольно возбуждает участие к автору.

Mikhail Milonov (1792-1821), mainly known for his satirical poems ("K Rubelliiu" directed against Arakcheev), occupied a position between the Shishkovites and Karamzinists. In his verse he approached the Decembrist writers. He also translated Schilkr. Milonov's poetry was printed in various journals beginning in 1807. His elegy "Padenie hist'ev" (1810) was widely popular. Pushkin used several lines from it for Lenskii's elegy in Eugene Onegin (chapter VI, stanzas 21-22). Milonov died in poverty.

1823 П. А. Плетнев, „Элегия Батюшкова ,У мнрающия Тасс' ” Журнал изящных искусств, III (1823).

Мы полагаем, что Умирающий Тасс есть лучшее стихотворение Батюшкова. Все его сочинения отличаются необыкновенно-счастливым созданием: в них мысли и чувства поражают читателя своею истиною, ясностию и легкостию; ход их всегда жив и точно обдуман. Но нигде столько не возможно удивляться превосходному составу стихотворения, как в Умирающем Тассе. Едва ли есть на каком-нибудь языке элегия, которая бы, подобно рассматриваемой нами. соединяла в себе столько высокого, трогательного и прекрасного. Одним словом: как целое. она совершенна.

The elegy "Umiraiushchii Tass," dated 1817, expresses the tragic fate of a poet who suffers undeservedly. Batiushkov looked upon Tasso's life as symbolic for the romantic writer who was disenchanted by the world and suffered in the chaos and disharmony of life.

Zhukovskii was often regarded as the creator of the modern elegy in Russian 
literature. Gogol said of him, "Elegicheskii rod nashei poezii sozdan im (Zhukovskim)." (N. V. Gogol, "V chem zhe, nakonets, sushchestvo russkoi poezii i v chem ee osobennost'," Vybrannye meste iz perepiski s druz'iomi, 1846).

Мне не нравится в новых наших поэтах односторонность их: пленясь элегическим родом они предпочитают его всем прочим. Виною этому прекрасные образцы, увлекаюшие за собою волею и неволею. Теперь должно будет еще выдержать натиск легиона узников и пленников которые непременно станут под знамена Байрона и Пушкина.

The elegy had become a prominent genre in the poetry of Zhukovskii and Batiushkov. Grech refers to Pushkin's poem "Kavkazskii plennik" (1821) and Zhukovskii's translation of Byron's poem "The Prisoner of Chillon" (originally published 1816; the Russian translation appeared in 1822).

1823 О. М. Сомов, „О романтической поэзни" Соревнователь просвещения и благотворения, 11 (1823).

Мы восстаем против поэзии классической новых времен, хотим расторгнуть гранищы, коими она стесняет воображение, - и добровольно подчиняемся новым условиям, налагаем на себя новые узы. Что же может быть ограниченнее, однообразнее тех стихов, которыми ежедневно наводняется словесность наша? Все роды стихотворений теперь слились почти в один элегический: везде унылые мечты, желание неизвестного, утомление жизнью, тоска по чем-то лучшем, выраженные непонятно и наполненные без разбору словами, схваченными у того или другого из любимых поэтов. Если бы взлумали составить лексикон сих слов, то, верно бы, он послужил такою ж пользою нашим временным стихотворцам, как лексикон рифм французским поэтам на подряд.

... Ни одна страна на свете не была столь богата разнообразными поверьями, преданиями и мифологиями, как Россия. Поэт может в ней с роскошью выбирать то, что ему правится, и отметить, что не нравится. Скажут, что все сии поверья, предания и мифологии неясны и мало известны. Может быть, но мы имеем две, довольно ясные и с которыми писатели нас ознакомили: мифологию древних славян и мифологию скандинавскую; сколько в России племен, верующих в Магомета и служащих в области воображения узлом, связующим нас с востоком. Итак, поэты русские, не выходя за пределы своей родины, могут 
перелетать от суровых и мрачных преданий севера к роскошным и блестящим востока, от образованного ума и вкуса европейцев к грубым и непритворным нравам народов звероловных и кочующих, от физиономии людей светских к облику какого-нибудь племени полудикого, запечатленного одною общею чертою отличия.

See above, p. 254f. Somov refers mainly to the sentimental-romantic elegy as cultivated by Zhukovskii. In the spirit of Herder, he points to another source of inspirationnational mythology, fairy tales, and folk songs. Note also Somov's understanding of two cultural and stylistic types, reflected in the landscape and the habits of the peoples settling there.

Slavic mythologies had been collected widely in the 18 th century, beginning with Lomonosov's Ancient Russian History (1766), and Mikhail Chulkov's and Mikhail Popov's collections (published in the 1760's and 1770's). A. Kaisarov, a member of Andrei Turgenev's Friendly Literary Society published a Versuch einer slevischen Mythologie in alphabetischer Ordnung (Gottingen, 1804; translated into Russian in 1807). Grigorii Glinka, university professor at Dorpat, and Pavel Stroev published their mythologies in 1808 and 1815 respectively. Romantic writers sometimes used Slavic mythology (largely invented) in place of the traditional Greek and Roman mythologies.

1823 А. А. Бестужев, „Ответ на крнтику Полярной звезды. помещенную в 4,5,6 и 7 нумерах Русского инвалида 1823 года" Сын итечества. LXXXIII (1823).

Русский инвалид:

,Дума есть особливый род поэзии взятый из польской литературы, и который требует еще своей теории.". . .

. . Думы суть общее достояние племен славянских. Русские песни о Владимире, о Добрыне и других богатырях, о взятии Казани: у малороссиян о Мазепе, о Хмельницком. о Сайгадашном; у богемцев вся Кралодворская рукопись; да и самая Песнь о походе Игоря не есть ли Дума? . . .

Но как у нас введена Дума Рылеевым, то по его словам и произведениям, Думу поместить должно в разряд чистой романтической поззии. Впрочем, она составляет средину между геройдою и гимном.

Bestuzhev quotes a line from a review of his article on Russian literature in Poliamaia zlezda. and then proceeds to supplement it with a more detailed description of the genre of the "duma." Ryleev, co-editor of Poliarnaie ziezda, published his "dumy" between 1821 and 1823 . They appeared in book form in 1825 .

Ivan S. Mazepa, Ukrainian hetman, supported the Swedes against Peter the Great; Z. Bogdan Khmel'nitskii, Ukrainian hetman (died 1657); Konashevich-Sagajdachnyi (died 1622), Ukrainian hetman; Kroledvorskaia rukopis'-ancient Czech manuscript supposedly discovered in 1817 in Kraledvor by Vaclav Hanka (1791-1861), a Czech poet and philologist. It is actually a falsification. 
1824 В. К. Кюхељбекер, „О направления нашей поэзни, особенно лирнческой, в последнее десятилетие"

Мнемозина. II (Москва, 1824).

Элегия и послание у нас вытеснили оду. Рассмотрим качества сих трех родов и постараемся определить степень их поэтического достоинства. . . .

Сила, свобода, вдохновение - необходимые три условия всякой поэзии. Лирическая поззия вообще не иное что, как необыкновенное, т.е. сильное, свободное, вдохновенное изложение чувств самого писателя. Из сего следует, что она тем превосходнее, чем более возвышается над событиями ежедневными, над низким языком черни, не знающей вдохновения. Всем требованиям, которые предполагает сие определение, вполне удовлетворяет одна ода, а посему, без сомнения, занимает первое место в лирической поззии, или лучше сказать, она одна совершенно заслуживает название поззии лирической. Прочие же роды стихотворческого изложения собственных чувств - или подчиняют оные повествованию, как то гимн, а еще более баллада и, следовательно, переходят в поззию эпическую; или же ничтожностию самого предмета налагают на гения оковы, гасят огонь его вдохновения. В последнем случае их отличает от прозы одно только стихосложение, ибо прелестью и благозвучием - достоинствами, которыми они по необходимости ограничиваются, - наравне с ними может обладать и красноречие. Ода, увлекаясь предметами высокими, передавая векам подвиги героев и славу отечества, воспоряя к престолу неизреченного и пророчествуя пред благоговеющим народом, парит, гремит, блещет, порабощает слух и душу читателя. Сверх того, в оде поэт бескорыстен; он не ничтожным событиям собственной жизни радуется, не об их сетует; он вещает правду и суд промысла, торжествует о величии родимого края, мещет перуны в супостатов, блажит праведника, клянет изверга.

В элегии - новейшей и древней - стихотворец говорит о самом себе, о своих скорбях и наслаждениях. Элегия почти никогда не окрыляется, не ликует: она должна быть тиха, плавна, обдуманна; должна, говорю, ибо кто слишком восторженно радуется собственному счастию смешон; печаль же неистовая не есть поэзия, а бешенство. Удел элегии умеренность, посредственность (Горациева aurea mediocritas).

. . . Она только тогда занимательна, когда, подобно нищему, ей удается (сколь жалкое предназначение!) вымолить, выплакать участие, или когда свежестью, игривою пестротою цветов, которыми осыпает предмет свой, на миг приводит в забвение ничтожность его. Последнему требованию менее или более удовлетворяют элегии древних и элегии Гетевы, названные им римскими; но наши Греи почти вовсе не искушались в сем светлом, полуденном роде поззии.

Послание у нас или та же элегия, только в самом невыгодном для 
ней облачении, или сатирическая замашка, каковы сатиры остряков прозаической памяти Горация, Буало и Попа, или просто письмо в стихах. Трудно не скучать, когда Иван и Сидор напевают нам о свонх несчастиях; еще труднее не заснуть, перечитывая, как они иногда в трехстах трехстопных стихах друг другу рассказывают, что слава Богу! здоровы и страх как жалеют, что так давно не видались! Уже легче, если по крайней мере ретивый писец, вместо того, чтоб начать:

Милостивый государь NN,

воскликнет :

. . . чувствительный певец,

Тебе (и мне) определен бессмертия венец!

- а потом ограничивается объявлением, что читает Дюмарсе, учится азбуке и логике, никогда не пишет ни ссм(), ни (вам() и желает быть ясным! - Душе легче, - говорю, - если он вдобавок не снабдит нас подробным описанием своей кладовой и библиотеки и швабских гусей и русских уток своего приятеля.

Tеперь спрашивается: выиграли ли мы. променяв оду на элегию и послание?

Kiukhel'beker, a "mladoarkhaist" (see above, p. 3), continued the demand already made by Andrei Turgenev that writers devote themselves to themes of national importance embodied in the major genres.

J. W. Goethe (1749-1832), Thomas Gray (1716-1771), A. Pope (1688-1744), Diumarse-Cesar Chesneau Du Marsais (1676-1756), French philologist and contributor to Diderot's Encyclopedie. His collected works were published by D'Alembert (1797). For Pushkin's reaction to Kiukhel'beker's views, refer to p. 220.

1825 К. Ф. Рылеев, [Первая редакиия преднсловия к „Думам”] Литературное нас.ледство, LIX (Москва, 1954), стр. 15-16.

Цель моя та же самая - то есть распространить между простым народом нашим, посредством Дум сих, хотя некоторые познания о знаменитых деяниях предков, заставить его гордиться славным своим происхождением и еще более любить родину свою. Счастливым почту себя, когда хотя несколько успею в своем предмете; еше счастливейшим, когда люди Благомыслящие ободрят мое намерение - пролить в народ наш хотя каплю света. 
Kondratii Ryleev (1795-1826), army officer and poet, participated actively in the Decembrist uprising (1825) and was hanged following the failure of the rebellion. In his Dumy (modeled after the Polish poet Niemcewicz), the intended to educate his readers in the spirit of Russian nationalism. See also below.:

1825 К. Ф. Рылеев, [ Преднсловие к отдельному изданию „Дум”] Думы, Соч. К. Ф. Рылеева (1825).

Думы - старинное наследие от южных братьев наших, наше русское, родное изобретение. Поляки заняли ее от нас. Еще до сих пор украинщы поют думы о героях своих: Дорошенке, Нечае, Сагайдачном, Палее, - и самому Мазепе приписывается сочинение одной из них. Сарницкий свидетельствует, что на Руси пелись элегии в память двух храбрых братьев Струсов, павших в 1506 году в битве с Валахами. „Элегии сии, - говорит он, - у русских думами называются. Соглашая заунывный голос и телодвижения со словами, народ русский иногда сопровождает пение оных печальными звуками свирели." . .

Peter Doroshenko, hetman of the Ukraine between 1665 and 1676; Nechai-Daniil Nechai-contemporary of Khmel'nitskii, cossack leader; Polei- Cossack leader (18th century); Stanislav Sarnitskii (born 1530), Polish chronicler and geographer; concerning Sogaidachnyi and Mazeppa see above.

Ryleev wrote to Pushkin in March 1825 concerning his "dumy": ,3наю, что ты не жалусшь мои Думы . . Чу Чствую сам, что некоторыс так слабы, что не следовало бы их и печатать в полном собрания. Но зато душевно, что Ермак, Матвеев. Волынския, Годунов и им подобные - хороши и могут быть полезны не для одних детей" (К. Ф. Рылеев. Полное собрание сочинений [1934], стр. 489).

Pushkin answered in May 1825, „Что сказать те6е о Думах? Во всех встречаюотся стихи живыс. окончательные строфы Петра в Острогахске чрезвычайно оригинальны. Но вообще все они слабы изобрстением и изложением. Все они на один покроя: составлены из обших мест (lосі торісі) . Описание места действия, речь героя и - нравоучение. Наинональьного, русского нет в них ничего, кроме имен, исключаю Нвана Сусанина. первую думу, по коей начал я подозревать в тебе истинныи талант. Ты напрасно не поправил в Олеzе гер6 Россия. Древния гер6, святой Георгия. не мог находиться на щите язычника Олега; новеЯшия двуглавыя орел есть герб византияския и принят у нас во время Иоанна III. Не прежде" (А. С. Пушкин. Полное собрание сочинений. XIII [1937-1959]).

1825 Н. И. Гнедич, „Простонародные песни ныпешних греков" Простонародные песни нынешних греков... (Санкт-Петербург, 1825).

Резкая особенность греческих песен исторических, для иностранца, конечно, чуждая, сильно поражает каждого русского, так сильно, что и тот, кто читал вскользь перевод французский, не мог во многих песнях не заметить чего-то знакомого, чего-то похожего на песни русские. 
Нечитающие по-гречечски могут подумать, что переводчик усиливался сообщить дух русский песням греков; так много между ними сходства. Не станем говорить о диких порывах гения и своевольных его переходах, сих свойствах, отличаюших нашу поззию простонародную и находимых в песнях греков; не станем говорить об оборотах, движении стиха, любимых повторениях речей и фраз, о многих чертах, которые составляют особенность песен русских и встречаются в греческвх, но которые приметны знаюшим оба языка.

Gnedich translated twelve Greek songs from a collection of thirty-five songs which had been collected in Greece from insurgents by Claude Ch. Fauriel (1772-1844). They were published in the original with a French prose translation (1824-1825). Gnedich's translation received the enthusiastic praise of Viazemskii, who extolled Gnedich's supreme mastery of various metres and his natural language which was close to that of Russian folklore.

$1826--$, ,Бнблиографня, Эда, фннляндская повесть, и Пиры, описательная поэма, Е. Баратынского"

Москозский телеграфб. ІІ (1826).

Имя Баратынского принадлежит к числу почтеннейших имен нового поколения русских поэтов. В романтической поззии русской, он самостоятельный поэт, не подражатель, но творец, и в том роде, в котором он пишет, доныне никто с ним не сравнялся. Область Баратынского в русской поэзии есть элегия, и оттенок ее наведен на все его сочинения. . . .

1826 - А. С. Пушкин, [Возражение на статьи Кюхельбекера в „Мнемозине“] 1827 ІІолное собриние сочинений. XI (1937-1959).

Нет; решительно нет - восторг исключает спокойствие. необходимое условие прекрасного. Восторг не предлолагает силы ума, располагающей частями в их отношении к целому. Восторг непродолжителен, непостоянен, следственно не в силе произвесть истинное великое совершенство (без которого нет лирической поззии). Гомер неизмеримо выше Пиндара - ода, не говоря уже об злегии. стоит на низших ступенях позм трагидия, комедия, сатира - все более требуют творчества (fantasie) воображения - гениального знания природы.

See above. pp. $217 f$. 
Возможна ли поэма эпическая, которая бы наши нравы, наши обычаи, наш образ жизни так передала потомству, как передал нам Гомер нравы, обычаи, образ жизни троян и греков? „Беппо” и „Дон-Жуан” Байрона и „Онегин” Пушкина - попытки в этом роде, но (надеюсь, всякий согласится) попытки очень и очень слабые, особенно если сравнить с „Илиадою" и „Одиссеею”; и не потому, что самые предметы Байрона и Пушкина малы и скудны (хотя и это дело не последнее), а главное, что они смотрят на европейский мир, как судьи,как сатирики,как поэтыописатели: личность их нас беспрестанно разочаровывает, - мы не можем обжиться с их героями, не можем забыться.

Comer-Homer; Beppo (1818) and Don Juan (1819-1824) are poems by Byron (17881824).

1841 В. Г. Белинскин̆, „Стихотворения М. Лермонтова” Отечественные записки. XIV, 2 (1841).

Как ни пристально будете вы вглядываться в поэму Лермонтова, не найдете ни одного лишнего или недостающего слова, черты, стиха, образа; ни одного слабого места: все в ней необходимо, полно, сильно! В этом отношении ее никак нельзя сравнить с народными легендами, носящими на себя имя их собирателя - Кирши Данилова: то детский лепет, часто поэтический, но часто и прозаический, нередко образный, но чаще символический, уродливый в целом, полный ненужных повторений одного и того же; поэма Лермонтова - создание мужественное, зрелое и столько же художественное, сколько и народное. Безыменные творщы этих безыскуственных и простодушных произведений составляли одно с веющим в них духом народности; они не могли от нее отделиться. она заслоняла в них саму же себя.

See above, pp. 161f. Mikhail Lermontov (1814-1841) published his first collection of poetry in 1840. Various poems had appeared earlier. His first publication, Khadzhi Abrek. had appeared in print in 1835. Belinskii refers here to his poem The Demon. 
1841 В. Г. Белинскй, „Разделенне поэзин на роды и виды” Отечественные записки, XV, 3 (1841).

Поззия есть высший род искусства. Всякое другое искусство более или менее стеснено и ограничено в своей творческой деятельности тем материалом, посредством которого оно проявляется. . . .

Поззия выражается в свободном человеческом слове, которое есть и звук, и картина, и определенное, ясно выговоренное представление. ПІосему поззия заключает в себе все элементы других искусств, как бы пользуется вдруг и нераздельно всеми средствами, которые даны порознь каждому из прочих искусств. Поззия представляет собою всю целость искусства, всю его организацию и, объемля собою все его стороны, заключает в себе ясно и определенно все его различия. . . .

В русских, например, песнях и эпических сказания х много поззии. но эта поззия заключена в тесном и заколдованном кругу народной индивидуальности, лишена общечеловеческого содержания и потому понятно и сильно говорит только русской душе, но безмолвна для всякого другого народа и непереводима ни на какой другой язык. IІо этой же причине наши народные песни и эпические сказания лишены всякой художественности и, сверкая местами яркими блестками поэзии. в то же время исполнены прозаических мест; часто мысль в них не находит своего выражения и лепечет намеками и символами. Только общечеловеческое. мировое содержание может проявиться в художественной форме.

1841 В. Г. Белинский, „Римские элегия” Отечественные записки. XVII, 8 (1841).

..Римские элегия" Гете явно есть то, что у нас в прошлом веке называлось легкою поззиею, а теперь получило название антологическої поэзии. Название это произошло от сборника мелких произведений греческой поэзия, или эпиграмм. . . .

Очевидно, что под антологическими стихотворениями древних должно разуметь то, что мы называем мелкими лирическими пьесами. 
Поззия древних во всех родах и в лирике и в драме, отличается эпическим характером; гимны Гезиода, оды Пиндара похожи на эпические позмы даже по своему объему: почти все они очень велики для лирических пьес. Следовательно, этиграммы древних соответствуют тому; что мы называем песнею, злегиею, сонетом, канцоною, стансами, надписями, эпитафиями и т. П. Оды Анакреона и Сафо - тоже эпиграммы. Отличительный характер эпиграммы - краткость, единство ощущения или мысли, спокойствие, наивность выражения, пластишизм и мраморная рельефность формы. . . .

Эпическая поэзия употребляет образы и картины для выражения образов и картин, в природе находяшихся; лирическая поззия употребляет образы и картины для выражения безобразного и бесформенного чувства, составляющего внутреннюю сущность человеческой природы. . ..

Лирика есть жизнь и душа всякой поззин; лирика есть поззия по преимуществу, есть поззия поззии, - и Жан-Поль Рихтер, сколько остроумно, столько и верно, называя ее обшим злементом всякой поззии, сравнивает ее обращающеюся кровью во всей поззии. Посему лиризм, существуя сам по себе, как отдельный род поззии, входит во все другие, как стихия, живит их, как огонь Прометеев живит все создания Зевеса... Без лиризма эпопея и драма были бы слишком прозанчны и холодно равнодушны к своему содержанию; точно так же, как они становятся медленны, неподвижны и бедны действием, как скоро лиризм делается преобладаюшим элементом их. . . .

Содержание антологических стихотворений может браться из всех сфер жизни, а не из одной греческой: только тон и форма их должны быть запечатлены зллинским духом.

. . . Поэт может вносить в антологическую поззию содержание совершенно нового и, следовательно, чуждого классицизму мира, лишь бы только мог выразить его в рельефном и замкнутом образе, этими волнистыми, как струи мрамора, стихами, с этою печатью виртуозности, которая была принадлежностию только древнего резца. К таким пьесам причисляем мы Пушкина: „Простишь ли мне ревнивые мечты”, „Ненастный день потух”, „Я вас любил" и „Безумных лет угасшее веселье"....

Антологическая поэзия допускает в себе элемент грусти, но грусти легкой и светлой, как таинственный сумрак жилища теней, как тихое безмолвие сада. уставленного урнами с пеплом почивших. . . . Грусть в антологической поэзии - это улыбка красавицы сквозь слезы. . . .

See above, pp. $185 f$.

Zhan-Pol' Rikhter-Jean Paul (Johann Paul Richter, 1763-1825), German romantic writer, published his views of romantic literature in Vorschule der Aesthetik (1804). Antologicheskaia poeziia-see p. 213 above.

Belinskii expresses a view which was central to romantic literature: the conver- 
gence of all genres in poetry. Karamzin had already voiced this tenet in the 1790's in a review of Kheraskov's Kadm i Garmoniia:

„но когда повесть есть не история, а вымысл, то она, кажется, есть поэма - эпическая или нет, но все поэма - стихамн или прозою писанная. но все позма, которая по общепринятому понятию на других языках означает всякое творение вообразительной силы. Таким образом комедия, роман есть поэма."

1843 В. Г. Белинский, „Сочинения Александра Пушкина” (статья II) Отечественные записки, XXX, 9 (1843).

Жуковский начал свое поэтическое поприще балладами. Этот род поззии им начат, создан и утвержден на Руси: современники юности Жуковского смотрели на него преимущественно как на автора баллад. и в одном своем послании Батюшков называет его „балладником". ІІод балладою тогда разумели краткий рассказ о любви, большею частию несчастной; могилу, крест, привидение, ночь. луну, а иногда домовых и ведьм считали принадлежностию этого рода поззии, больше же ничего не подозревали. Но в балладе Жуковского заключался более глубокий смысл, нежели могли тогда думать. Баллада и романс - народная песня средних веков, прямое и наивное выраженис романтизма феодальных времен, произведения по преимуществу ро.мантические. Первою балладою, обратившею на Жуковского общее внимание, была „Людмила", переделанная из Бюргеровой ,.Леноры”. которую он впоследствии перевел (т. IV , стр. 69). .Ленора" Бюргера доставила в Германии громкое имя своему творцу. Золотое то время. когда подобными вещами можно снискивать себе славу! Такое время миновалось даже для России. Но „Людмила” Жуковского явилась кстати: она имела успех вроде того, каким воспользовались ,Душенька" Богдановича и „Бедная Лиза" Карамзина. Для руссской публики все было ново в этой балладе. . . .

Романา ическая лира Эллады умела воспевать не однс только счастье любви, как страстное и изящное наслаждение, и не одну муку неразделенной страсти: она умела плакать еще и над урною милого праха, и элегия - этот удьтра-романтический род поззии - была создана ею же. светлою музою Эллады. Когда от страстно любящего сердца отнимала предмет любви прежде, чем жизнь отнимала любовь, - грек умел любить скорбною памятью сердца.

Впрочем, роматнизм не был преобдадающим элементом в жизни греков: он даже подчинялся у них другому, более преобладающему элементу - общественной' и гражданской жизни. ІІоэтому романтизм греческий всегда ограничивался и уравновешивался другими сторонами элллинского духа и не мог доходить до крайностей нелепого. 
Between 1843 and 1846, Belinskii published a cycle of eleven articles devoted to Pushkin's works in the journal Otechestvennye zapiski. In them the critic addressed himself to many questions regarding literature and literary theory which were not directly related to Pushkin's work. Conceming the ballad, see also pp. 208-211.

1844 В. Г. Белинский, „Сочинения Алесандра Пушкина” (статъя VII) Отечественные записки, XXXIV, 5 (1844).

. . . А есть большая разница между романом или повестью и между поэмою. Поэма рисует идеальную действительность и схватывает жизнь в ее высших моментах. Таковы поэмы Байрона и, порожденные ими, поэмы Іушкина. Роман и повесть, напротив, изображвют жизнь во всей ее прозаической действительности независимо от того, стихами или прозою они пишутся. И потому „Евгений Онегин” есть роман в стихах; но не поэма; а „Граф Нулин” - повесть в стихах, но не поэма. В „Онегине" и „Нулине" мы видим лица действительные и современные нам; в „Цыганках" все лица идеальные, как эти греческие изваяния, которых открытые глаза не блещут светом очей, ибо они одного цвета с лицом: так же мраморны или медяны, как и лищо.

. . Итак, в „ІІолтаве” ему хотелось сделать опыт эпической поэмы в новом духе. Что такое эпическая поэма? - Идеализированное представление такого исторического события, в котором принимал участие весь народ, которое слито с религиозным, нравственным и политическим существованием народа и которое имело сильное влияние на судьбы народа. Разумеется, если это событие касалось не одного народа, но и целого человечества, - тем ближе поэма должна подходить $\kappa$ идеалу эпоса. Так смотрели на эпическую поэму все образованные люди со времен древнегреческой национальности и возникновения алексанрийской школы почти до начала XIX столетия, следовательно, более двуX тысячи лет.

\section{В. Г. Белинский, „Иван Андреевнч Крылов”} Отечественные записки. XXXVIII, 2 (1845).

Роды поэзии всегда были и всегда будут одни и те же; они изменяются, сообразно с национальностями и эпохами, в духе и направлении, но не в форме. ...

Крылов, как гениальный человек, инстинктивно угадал эстетические законы басни. Можно сказать, что он создал русскую басню. И его инстинктивное стремление потом перешло в сознательное убеждение. Крылова басни можно разделить на три разряда: 1) басни, в 
которых он хотел быть просто моралистом и которые слабы по расказу; 2) басни, в которых моральное направление борется с позтическим, и 3) басни чисто сатирические и поэтические (потому что сатира есть поззия басни).

Ivan Krylov (1768-1844) published a volume of fables in 1809. Many of his verses have become proverbial (see also p. 37 above).

The fables were received enthusiastically. Gogol later said, "Ni odin in poetov ne umel sdelat' svoiu mysl' tak oshchutitel'noi i vyrazhat'sia tak dostupno vsem, kak Krylov." In 1811, Krylov was elected a member of Admiral Shishkov's literary society "Beseda."

1847 В. Г. Белкнский, „Взгляд на русскую литературу 1846 года” Современник, 1 (1847).

Один из самых поразительных признаков зрелости современной русской литературы, - это роль, которую играет в ней стихотворная поззия. Стихи играют второстепенную в сравненин с прозою роль. Их читают будто нехотя, едва замечают, хладнокровно похваливают хорошее и ничего не говорят о посредственном. Стихотворцев против прежнего стало теперь несравненно меньше. . . Это значит, что вкус публика к стихам сделалсв разборчивее, требования строже, а это, конечно, успех, а не упадок вкуса. Теперь нужен новый Пушкин, новый Лермонтов. чтобы книжка стихотворений привела в восторг всю публику. в движение - всю литературу.

1850 Н. А. Некрасов, „Русские второстепенные поэты" Созрсменник, 1 (1850).

Стихов нет. Немногие об этом жалеют, многие этому радуются, большая часть ничего об этом не думает. . . Несколько лет тому назад. при оценке литературного произведения, прежде всего обращали внимание на слог. потому что хороший слог был явлением редким; теперь же почти не говорят о слоге. потому что все пишут более или менее хорошо. Пушкин и Лермонтов до такой степени усвонли нашему языку стихотворную форму, что написать теперь гладенькое стихотворение сумеет всякий, владеющий в некоторой степени механизмом языка; и потому гладкость и правильность стиха не составляют уже в наше время ни малейшего достоинства. . . .

Вот главная причина, почему нет стихов вообще. Почему нет хороших стихов, тому другая причвна: нет позтических талантов или их слишком мало и они также обратились к прозе. . . . И сознавая, что 
в наше время только поэтический талант, равный пушкинскому, мог бы доставить автору и Слвву и Деньги, он предпочитает распорядиться иначе: поэтическую искру свою разводит он на множество прозаических статей: он пишет повести, рецензии, фельетоны и, получая за них с журналистов хорошие деньги, без сожаления видит, как поэтическая способность его с каждым годом уменьшается, как даже самая форма, которою он овладел бьло в значительной степени, делается ему с каж:дым годом менее доступною и, наконец, представляет ему трудности непреодолимые. . . .

Наши журналы смотрят и приучили смотреть свокх читателей на всякую новую книжку стихов так недружелюбно, что может случиться, что и человек весьма умный, чувствующий в себе поэтический талант, побоится выступить со своими стихами в такое невыгодное для поэтов время. . . .

Собственно, публика считает у нас за последний литературный период пять поэтических் имен: Пушкина, Жуковского, Крылова, Лермонтова. Кольцова; некоторые причисляли к ним г. Бенедиктова, но о таковых не.следует упоминать. Что касается до первых пяти, то они действительно могут быть названы светилами русской поэзии, из которых каждое светит своим собственным светом, не заимствуя ничего у другого. И нет человека на Руси, сколько-нибудь читающего, который не знал бы их. Их стихотворения много раз почитаны. . . .

В 1836 году ІІушкин основал новый журнал Современкик. Основание этого журнала и появление первых его книжек сопровождалось в нашей литературе весьма замечательными толками, спорами и событиями, о которых мы скоро будем иметь случай говорить в особой статье. Теперь же переходим прямо к нашему делу: с третьего же тома в Современнике начали появляться стихотворения, в которых было столько оригинальности, мысли и прелести изложения, столько, однкм словом, поэзии, что казалось, только сам же издатель журнала мог быть автором их. Но под ними весьма четко выставлены были буквы Ф. T.; носили они одно общее название: Стихотворения, присланные из Германии.

Прежде всего скажем, что хотя они и присылаемы были из Германии, но не подлежало никакому сомнению, что автор их был русский: все они написаны были чистым и прекрасным языком, и многие носили на себе живой отпечаток русского ума, русской души. Подпись $Ф$. Т-B, вместо Ф. Т., появившаяся вскоре под одним из них, окончательно подтвердила, что автор их наш соотечественник. Сделав это замечание для тех, которых могло бы испугать заглавие стихотворений, мы продолжаем. С тех пор (с 1836) время от времени продолжали появляться в Современнике стихотворения за этою подписью, до 1840 года включительно. С 1841 года мы уже не встречали этого имени в Современнике; 
в других журналах оно также не появлялось, и можно сказать, что с того времени оно вовсе исчезло из русской литературы... . .

Между тем стихотворения г. Ф. Т. принадлежат к немногим блестящим явлениям в области русской поэзии. Г. Ф. Т. написал очень немного; но все натнсанное им носит на себе пеуать истинного и прекрасного таланта, нередко самобытного, всегда гращиозного, исполненного мысли и неподдельного чувства. Мы уверены, что если 6 r. Ф. Т. писал более, талант его доставил бы ему одно из почетнейших мест в русской поззии.

F. T.-Fedor Tiutchev (1803-1873), diplomat and poet, had already published poems in the 1820's and early 1830's in the almanacs Uraniia. Severnaia lira. Dennitsa, Galateia. and the journal Teleskop.

Vladimir Benediktor (1807-1843), late romantic poet, wrote in an affected style, overburdened with colorful epithets. 


\section{DRAMA}

1808

---, „Рекрутский набор, соч. И. Ильнва"

Драматический вестник, I, 8 (1808).

Это . . д драма, которая в своем роде очень близко к совершенству.

Даже и самый род сих сельских происшествий, уступающий правильной комедии, кажется должен взять преимущество перед немецкими романическими драмами, где почти всегда сказка сплетена чудесным образом, где действие не редко бывает без причин, где оно останавливается по получасу, чтобы дать какому-нибудь низкорохденно-благородному' нравоучитель высказать все то, что автор затвердил из новых филюсофов, и чем он наполняет две третьи драмы, оставляя последнюю для узнания законно или незаконно рожденных детей, для обмороков, утоллений, грому, дождя, обеда, завтрака, ужинов, курения табаку, описания ничтожных подробностей и, наконец, немых картин которыми кончаются действия.

The play Velikodushie, ili Rekrutskii nabor (1803) by the sentimental playwright N. I. Il'in treated a theme which appeared more than once in early romantic literaturethe selling of recruits to the government (cf. Schiller's play Kabale und Liebe).

The reviewer's wrath was directed against the type of German Storm and Stress (Sturm und Drang) drama which was popular in Russia during the first decade of the 19 th century. Among Russian writers, Narezhnyi and $G$ nedich wrote several such dramas in their early youth.

$1811---$, ,Следствие пылких и необузданньх страстей, трагедия в пяти действиях, 1811"

Санкт-Петербургский вестник, 1,2 (1812).

Ужасная трагедия! В ней беспрестанно рубят, режут, жгут, отравляют ядом! Двенадцать мертвецов, две отрубленные головы, одна голова в ящике - какой богатый предмет для трагика! На кахдой странице сочинитель восклищает: чорт! Дьявол! Дьявольшина! Чорт побери! Эй! А! О! Ну! Ге! Фуй! Га! Гм! Ба! Ха! Ха, ха! Этот драматический бред писан прозою; содержание выкрадено из немецкого романа: Куно фон Кибург. 
The Russian play was based on Heinrich Zschokke's (1771-1848) early novel Kuno von Kyburg (1795-1799), which had been translated into Russian in 1809. The full title was Kuno fon-Kiburg vzial serebrianyi lokon obezglavlennogo $i$ unichtozhil tainyi sud Inkvizitsii (translated by Ivan Kuzikov in St. Petersburg). The novel and the drama were both in the preromantic spirit, characterized by a hyperbolical style and the cruel deeds of powerful, demonic individuals.

1811 Г. Р. Державин, „Рассужденне о лирнческой поэзкн или об оде” Чтение в Беседе любителей русского слова. II (1811); VI (1812); XIV (1815).

Она (опера) . . . сокращение всего зримого мира . . она есть живое царство поззия; ... . в ней представляются сражения, победы, торжества. великолепные здания, хижины, пещеры, бури, молнии, громы, волнующие моря, кораблекрушения, бездны, пламень изрычающие. Или В противоположность тому: приятные рощи, долины, журчащие источники, цветущие луга, класы, зефиром колеблемые. зари, радуги, дожди. луна, в нощи блистающая, сияющее полуденное солнще; в ней нисхоцят на землю облака, сидят на них боги, летают гения, являются привидения, чудовища, звери, рыкают львы, ходят деревья, возвышаются и исчезают холмы, поют птищы, раздается зхо. Словом видим перед собою волшебный, очаровательный мир, в котором взор объемлется блеском, слух гармониею, ум непонятностию. . . .

И человек познает тут все свое величие и владычество над вселенной.

The opera had become a popular genre in the last third of the 18 th century in the wake of the late baroque (rococo) trend in the fine arts and architecture. As Derzhavin noted, its devices and practices lent themselves particularly well to the romantic imagination. The merging of architectural, musical, and picturesque features with poetry and fairy tale subjects corresponded to the romantic taste. Operas were widcly popular during the first decade of the 19th century and were linked with the evolving romantic trend. See above, p. 87.

1813 И. М. Муравьев-Апостол, --Сын отечества. X (1813), стр. 224225.

Если комедия есть живое в лицах представление господствующих нравов. то каждый народ должен иметь свою комедию по той самой причине, что каждый народ имеет свои собственные нравы и обычаи. 
1817 Н. И. Греч, „Обозренне русской литературы в 1815 и 1816 годах” Сочинения Николая Греча, III (1855).

Творения Озерова составили новую эпоху в истории русской драматической поззия. Читатели и зрители обыкновенные могут находить в его трагедиях одно механическое превосходство стихов и слога пред его предшественниками, но прилежный наблюдатель поэзия отечественной должен видеть в них достоинство гораздо важнейшее. До Озерова трагедии наши были не иное что, как рабские, одноцветные копии образцов иностранных. Озеров дал им краски! Он оживил их истинною поэзиею, которая, не довольствуясь вымыслом и расположением происшествий и отделкою слога, находит сушество и превосходство свое в красотах высшего рода. Эдип, Фингал, Димитрий и Поликсена единственны в своем роде, и доныне сочинитель их не имеет даже соперников; эти трагедии останутся украшением Русского Театра.

N. I. Grech (1787-1867) seems to have initiated the custom of publishing annual reviews (obozreniia) of literature in his own joumal Syn otechestva, where the above review first appeared. These annual reviews were originally little more than extensive bibliographical notes. In the 1820 's and later, critics wrote comprehensive studies of the literary evolution under this title. Well-known are Bestuzhev-Marlinskii's surveys in Poliarnaia zvezda. Belinskij's surveys of 1846 and 1847 in Sovremennik, and Ivan Kireevskii's reviews (e.g., in Dennitsa. 1830). Grech, who pioneered this genre, was widely praised for his initiative.

Vladimir A. Ozerov (1769-1816), a well-known poet and playwright of the first two decades of the 19th century, wrote the tragedies Edip $v$ Afinakh (1804), Fingal (1805), Dmitrii Donskoi (1807), and Poliksena (1809). Viazemskii praised Fingal as an example of a romantic drama (see p. 88 and below).

П. А. Вяземскнй, „О...хизнн и сочинениях В. А. Озерова”

В. А. Озеров, Сочинения, 1 (1817).

... Нет сомнения, что чтение романов дало его [Озерова] поэзии ивет романизма. заметный почти на всех его произведениях, и удивительно, как с таким расположением не искал он для содержания трагедий своих повестей из рыцарских веков.

... Трагедия Озерова . . . и в самых погрешностях своих представляют нам отступления от п правил, исполненные жизни и носяшие свой образ. Они уже несколько принадлежат к новейшему драматическому роду, так называемому романтическому, который принят немцами от испанцев и англичан. Оценяя достоинство Озерова как трагика, справедливость принуждает нас заметить, что трагику на равной степени совершенства с другими писателеями должно всегда 
бороться с большими препятствиями для достижения своей цели, а тем более у нас, где и самый язык, еще не смягченный употребленисм, столь упорствует против усилий писателя.

. . . Озеров-трагик может и должен служить образцом на театре нашем. Как позт, хотя и неоспоримо утвердившийся на чреде первейших поэтов, не может и не должен он быть образцовым. В самих красотах слога он более счастлив, нежели правилен. ... .

В 1807 году, когда взоры России устремлены были на борьбу храбрых сынов ее с силою грозного врага, готовившего цепи рабства Европе, Озеров в трагедии Дмитрий Донской напомнил согражданам своим о великой зпохе древней славы России, когда на Задонских полях нанесен был сильный удар власти Мамая, кичливого противника русской свободы. Озеров возвратил трагедии ее достоиство: питать гордость народную священными воспоминаниями и вызвать из древности подвиги великих героев, благотворителей современникам, служащих образом для потомства. Исторические трагедии, или, по крайней мере, трагедии, основанные на вымышленной повести, вставленной в историческую раму, должны всегда иметь преимущество пред другими.

Pushkin commented in 1826, ,.Болышая разница. Карамзин всликия писатель..., а Озеров - очень посредственныя. Озеров сделал шаг вперел в слоге. но искусство чуть не отступило. Геркулевского в нем нет ничето" (А. С. Пушкин. Полное Собрание сочинений. XII | Москва-Ленинград. 1937-1959]. стр. 215).

Already in an earlier letter of February 6,1823 Pushkin had told Viazemskii, „знаю, за что полагаешь его поэтом романтическим: за мечтательныя монолог Фингала. - Нет! Песням никогда надтробным я не внемлю. но вся трагедия написана по всем правилам парнасского православия. "(i.e., classicism.) On the other haרd. Pushkin praised the intention of Viazemskii's essay:

..Все что ты говоришь о романтической поззии. прелестно; ты хорошо сделал. что первыя возвысил за нес голос. - французская болезнь умертвила 6 нашу отроческую словесность" (там же).

P. A. Katenin writing in Syn otechesria in 1822 (LXXVI, "Pis'mo k Izdateliu") took issue with Viazemskii and maintained that Ozerov was more imitative than innovative.

1825 А. С. Пушкин, [O трагедни ]

Полное собрание сочинений. XI (Москва, 1962).

Изо всех родов сочинений самые неправдоподобные (invraisemblables) сочинения драматические, а из сочинений драма гических - трагедии. ибо зритель должен забыть, по большей части, время, место, язык; должен усилием воображения согласиться в известном наречии - к стихам. к вымыслам. Французские писатели зто чувствовали и сделали свои своенравные правила: действие. место, время. Занимательность. будучи первым законом драматического искусства, единство действия должно быть соблюдаемо. Но место и время слишком своенравны: от сего 
происходят такие неудобства, стеснение места действия. Заговоры, изъяснения любовные, государственные совещания, празднества - все происходит в одной комнате! - Непомерная быстрота и стесненность происшествий наперсника . . . а parte столь же несообразны с рассудком, принуждены были в двух местах и проч. И все это ничего не значит. Не короче ли следовать школе романтической, которая есть отсутствие всяких правил, но не всякого искусства?

Интерес - единство.

Смешение родов комического и трагического, - напряжение, изысканность необходимых иногда простонародных выражений.

Pushkin refers to the three unities of time, place, and action which were fundamental for classicist and neoclassicist plays, but were disregarded by many romantic play. wrights (especially the two first mentioned). Already in the 18 th century, sentimental dramatic theory (Diderot, Beaumarchais. Gellert) had advanced two new dramatic genres, the domestic tragedy and the serious comedy (tearful comedy), as dramatic forms which were situated between the extreme poles of classicist tragedy and comedy.

1825 А. С. Грибоедов, [Письмо П. А. Катенину от января 1825 г. ] Ilo.ıное собрание сочинений. III (1913).

ІІишу для подобных себе, а я, когда по первой сцене угадываю десятую, раззеваюсь и вон бегу из театра. „Характеры портретны". Да! И я, коли не имею таланта Мольера, то по крайней мере чистосердечнее его; портреты и только портреты входят в состав комедии и трагедии, в них, однако, есть черты, свойственные многим другим лицам, а иные всему роду человеческому настолько, насколько каждый человек похож на всех своих двуногих собратий. Карикатур ненавижу, в моей картине ни одной не найдешь. Вот моя поэтика. . . .

See pp. $234,238,241 \mathrm{ff}$.

Griboedov's drama Gore of uma was written between 1821 and 1823. Scenes seven to ten from the first act and all of the second act were published in the almanac Russkaio taliia in 1825. Five years later the Bolshoi Theatre in Moscow performed the third act. The entire comedy was first performed in the same theatre in 1831. The same year a German translation of it appeared in Reval. The original Russian version was published in Moscow in 1823 (2nd edition, 1839). The comedy was widely discussed in the periodical press the year preceding the Decembrist uprising, and again in the early 1830's when it was performed and appeared in print. Griboedov maintained the three unities. In this as in other respects his comedy is still part of the 18 th century tradition. 
1825 О. М. Сомов, „Мон мысли о замечаниях г. Мих. Дмитрнева на комедио "Горе от ума' н о характере Чацкого"

Сын отечества, CI, 10 (1825).

Сочинитель ее не шел и, как видно, не хотел идти тою дорогою, которую углаживали и наконец истоптали комические писатели, от Мольера до Пирона и наших времен. Посему обыкновенная французская мерка не придется по его комедии. Здесь нет ни плута-слуги, около которого вьется вся интрига, нет ни јеune prémier, ни grand coquette, ни père noble, ни raisonneur, словом, ни одного сколка с тех лиц, которых полное число служит во франиузских театрах уставом для набора театральной челяди. В первом явлении первого действия не выведены слуга и служанка или два другие из действующих лиц, чтоб высказывать зрителям или читателям характеры главных лии комедии и, вместе с тем, сообщить наперед, в чем состоит завязка пьесы. Здесь характеры узнаются и завязка развертывается в самом действия; ничто не подготовлено, но все обдумано и взвешено с удивительным расчетом.

Piron-Alexis Piron (1685-1773), French poet and playwright.

1828 А.С. Пушкин, „Пнсьмо о Борисе Годунове” Московский вестник (1828).

По примеру ІІЈекспира я ограничился развернутым изображением э1охи и исторических лиц. не стремясь к сценическим зффектам, к романтическому пафосу и т. п. . . . Стиль трагедия смешанный. Он площадной и низкий там, где мне приходилось выводить людей простых и грубых, - что касается грубых непристойностей, не обращайте на них внимания: это писалось наскоро и исчезнет при первой же переписке. Меня прельщала мысль о трагедии без любовной интриги. Но, не говоря уже о том, что любовь весьма подходит к романическому и страстному характеру моего авантюриста, я заставил Дмитрия влюбиться в Марину, чтобы оттенить ее необычайный характер. У Карамзина он лишь бегло очерчен. Но, конечно, это была странная красавища. У нее была только одна страсть: честолюбие. но до такой степени сильное и бешеное, что трудно себе представить. . . .

В Дмитрии много общего с Генрихом IV. Подобно ему он храбр, великодушен и хвастлив, подобно ему равнодушен к религия - оба они из политических соображении отрекаются от своей веры, оба любят удовольствия и войну, оба увлекаются несбыточными замыслами, оба являются жертвами заговоров. . . . 
Создавая моего Годунова, я размышлял о трагедии - если бы вздумал написать предисловие, то вызвал бы скандал - это, может быть, нанменее понятый жанр. Законы его старались основать на правдоподобия, а оно-то именно и исключается самой сушностью драмы; не говоря уже о времени, месте и проч., какое, черт возьми, правдоподобие может быть в зале, разделенной на две части, из кокх одна занята 2000 человек, будто бы невидимых для тех, которые находятся на подмостках.

Pushkin's drama Boris Godunov was written in 1824-1825, but appeared in print only in 1831. The first performance took place in 1870 in St. Petersburg. Excerpts from the play were published in 1827 and 1828 in Moskovskii vestnik and Sevemye tsvety no $1828 \mathrm{god}$. See also below.

1828 А. С. Пушкнн, „Письмо к издателю ,Московского вестника' " Литературное наследство (1934), стр. 697.

С 1820 года, будучи удален от московских и петербургских обществ, я в одних журналах мог наблюдать направление нашей словесности. Читая жаркие споры о романтизме, я вообразил, что и в самом деле нам наскучила правильность и совершенство классической древности и бледные, однообразные списки ее подражателей, что утомленный вкус требует иньх, сильнейших ощущений и ищет их в мутных, но кипящих источниках новой, народной поэзии.

Твердо уверенный, что устарелые формы нашего театра требуют преобразования, я расположил свою трагедию по системе Отца нашего llекспира и принес ему в жертву пред его алтарь два классические единства, едва сохранив последнее. Кроме сей пресловутой тройственности, есть единство, о котором французская критика не упоминает (вероятно, не предполагая, что можно оспоривать его необходимость), единство слога - сего 4-го необходимого условия французской трагедии, от которого избавлен театр испанский, английский и немецкий. Вы чувствуете, что и я последовал столь соблазнительному примеру.

Что сказать еще? Почтенный александрийский стих переменил я на пятистопный белый, в некоторых сценах унизился даже до презренной прозы, не разделил своей трагедии на действия, - и думал уже, что публика скажет мне больщое спасибо.

Отказавшись добровольно от выгод, мне представляемых системою искусства, оправданной опытами, утвержденной привычкою, я старался заменить сей чувствительный недостаток верным изображением лиц, времени, развитием исторических характеров и событий, - словом, написал трагедию истинно романтическую. . . . 
Хотите ли знать, что еще удерживает меня от напечатания моей трагедия? Те места, кои в ней могут подать повод применениям, намекам. allusions. Благодаря французам мы не понимаем, как драматический автор может совершенно отказаться от своего образа мыслей, дабы совершенно переселиться в век, им изображаемый . Француз пишет свою трагедию с "Constitutionnel" или с „Quotidienne" перед глазами.

1830 А. С. Пушкин, [О народной драме и о „Марфе Посаднице” М. П. Потоднна ] Собрание сочинений. IV (Москва, 1962).

Драматическое искусство родилось на площади - для народного увеселения. Что нравится народу, что поражает его? Какой язык ему понятен?

С пиощадей, ярмарки (вольность мистерий) Расин переносит ее во двор. ...

Что развивается в трагедии? Какая цель ее? Человек и народ Судьба человеческая, судьба народная. Вот почему Расин велик, несмотря на узкую форму своей трагедии. Вот почему ІІекспир велик, несмотря на неравенство, небрежность, уродливость отделки.

Что нужно драматическому писателю? Философия, бесстрастие, государственные мысли историка, догадливость, живость воображения, никакого иредрассудка любимой мысли. Свобода.

. . . Народ, как дети, требует занимательности, действия. Драма иредставляет ему необыкновенное, странное происшествие. Народ требует сильных ощущений, для него и казни - зрелище. Смех. жалость и Іжас суть три струны нашего воображения, потрясаемые драматическим волшебством. Но смех скоро ослабевает, и на нем одном невозможно основать полного драматического действия. Древние трагики пренебрегали сею пружиною. Народная сатира овладела ею исключительно и приняла форму драматическую, более как народную. Таким образом родилась комедия, со временем столь усовершенствованная. Заметим. что высокая комедия не основана единственно на смехе, но на развитии характеров, и что нередко близко подходит к трагедии.

Трагедия преимущественно выводила тяжкие злодеяния, страдания сверхъестественные, даже физические (напр. Филоктет, Эдип, Лир). Но привычка притупляет ощущения - воображение привыкает к убийствам и казням, смотрит на них уже равнодушно, изображение же страстей и излияний души человеческой для него всегда ново, всегда занимательно, велико и поучительно. Драма стала заведовать страстями и душою человеческою. 
Истина страстей, правдоподобие чувствований в предполагаемьх обстоятельствах - вот чего требует наш ум от драматического писателя.

... [Шекспир] творец трагедии народной был образованнее своих зрителей, он это знал, давал им свои свободные произведения с уверенностию своей возвышенности и признанием публики, беспрекословно чувствуемым. При дворе, наоборот, поэт чувствовал себя ниже своей публики. Зрители были образованнее его; по крайней мере так думали и он и они. Он не предавался вольно и смело своим вымыслам. Он старался угадывать требования утонченного вкуса людей, чуждых ему по состоянию. Он боялся унизить такое-то высокое звание, оскорбить таких-то спесивых своих зрителей.

Romantic writers differentiated between two concepts of people-the negative rabble (chern\%, and the positive nation (narod). While they tended to look down upon the uneducated masses, they idealized the more abstract concept of the nation.

Filoktet-Philoctetes, Greek archer who slew Paris in the battle for Troy. The legend was dramatized in a play by Sophocles; Edip-King Oedipus, the principal character of three plays by Sophocles; Lir-King Lear, hero of Shakespeare's tragedy; Shekspir-William Shakespeare.

1831 Н. И. Надеждин, ---

Телескоп. I (1831), стр. 35-38.

Нынешняя драма есть совершенная история; только - она повторяет на деле то, что история воспоминает в рассказе. . . .

Своей беспредельной всеобъемлемостью допускающей все формы представления и все тоны выражения, она представляет просторную раму для свободного живописания беспредельной пучины жизни.

Pushkin and Nadezhdin, the authors of the above two excerpts, discussed M. P. Pogodin's historical drama Marfa Posadnitsa which had been published in 1830. Nadezhdin said of it later, "ona predstavliaet soboi pervyi opyt russkoi istoricheskoi dramy i ukazyvaet novoe poprishche russkomu natsional'nomu teatru" (Teleskop, VII [1832], p. 312). Pogodin's drama had followed Pushkin's Boris Godunov and Khomiakov's historical drama Ermak (performed 1827, printed 1832). Khomiakov's second historical drama, Dmitrii Somozvanets, was performed in 1833. Pogodin wrote another historical tragedy, Petr I (1831). Other similar works were M. V. Kriukovskii's Pozharskii (1832), V. Kiukhel'beker's Prokofii Liapunor (written 1834), and several plays by N. V. Kukol' nik (1809-1868), Ruka vsevyshnego otechestvo spasla (1834), Kniaz' M. V. SkopinShuiskii (1835), and others. Like the historical novel, the drama using events from Russian history came to prominence in the course of the 1830's. 
1833 В. К. Кюхељбекер, Дневник В. К. Кюхельбекера (Ленинтрад, 1929).

8 февраля.

.Нет действия в „Горе от ума!" - - говорят гг. М. Дмитриев, Белугин и братия. Не стану утверждать, что это несправедливо, хотя и не трудно было бы доказать, что в этой комедия гораздо более действия или движения, чем в большой части тех комедий, которьх вся занимательность основана на завязке. В „Горе от ума”, точно, вся завязка стостоит В противоположности Чацкого прочим лицам; тут, точно, нет никаких намерений, которых одни желают достигнуть, которым другие противятся, нет борьбы выгод. нет того, что в драматургии называется интригою. Дан Чацкий, даны прочие характеры, они сведены вместе, и показано, какова непременно должна быть встреча этих антиподов, - и только. Это очень просто, но В сей-то именно простоте - новость, смелость, всличие того поэтического соображения, которого не поняли ни противники Грибоедова, ни его неловкие зашитники. Другой упрек касается неправильностей, небрежностей слога Грибоедова, и он столь же мало основателен. ... .

С одной стороны, опущения союзов, сокращения, подразумевания. с другой плеоназмы, - словом, именно то, чем разговорный язык отличается от книжного.

1834 В. Г. Белинскнй, „Лятературные мечтаняя" Mosksa. 38-52 (1834).

. . . Лиризм, эпопея, драма: отдаете ли вы чем-нибудь из них решительное прелпочтение или все это любите одинаково? Трудный выбор? Не правда ли? Ведь в мощных строфах богатыря Державина и в разнообразных напевах Протея Пушкина преображается та же самая природа. что и в позмах Байрона или романах Вальтера Скотта, а в сих последних та же самая, что и в драмах Шекспира и Шиллера? И, однако же. я люблю драму предпочтительно, и, кажется, это общий вкус. Лиризм выражает природу неопределенно и, так сказать, музыкально; его предмет - вся природа во всей ее бесконечности; предмет же драмы есть исключительио человек и его жизнь, в которой проявляется высшая, духовная сторона всеобщей жизни вселенной. Между искусствами драма есть то же, что история между науками. Человек всегда был и будет самым люболытнейшим явлением для человека, а драма представляет этого человека в его вечной борьбе с своим $я$ и с своим назначением, в его вечной деятельности, источник которой есть стремление к какому-то темному идеалу блаженства. редко им постигаемого и еще реже 
достигаемого. Сама эпопея от драмы занимает свое достоинство; роман без драматизма вял и скучен. В некотором смысле эпопея есть только особенная форма драмы. Итак, положим, драма есть если не лучший, то ближайший к нам род поззии. . . .

Предмет комедия не есть исправление нравов или осмеяние каких-нибудь пороков общества; нет: комедия должна живописать несообразность жизни с целию, должна быть плодом горького негодования, возбуждаемого унижением человеческого достоннства, должна быть сарказмом, а не эпиграммою, судорожным хохотом, а не веселою насмешкою, должна быть писана жельчю, а не разведенною солью словом, должна обнимать жизнь в ее высшем значении, то есть в ее вечной борьбе между добром и злом, любовию и згоизмом. . . .

Комедия, по моему мнению, есть такая же драма, как и то, что обыкновенно называется трагедиею; ее предмет есть представление жизни в противоречии с идеею жизни; ее элемент есть не то невинное остроумие, которое добродушно издевается над всем из одного желания позубоскалить; нет: ее элемент есть этот желчный гумор, это грозное негодование, которое не улыбается шутливо, а хохочет яростно, которое преследует ничтожество и эгоизм не эпиграммами, а сарказмами.

Belinskii expresses romantic views of the comic. Schelling said that the essence of the comic consisted in the contradiction between reality and the ideal. This view was expressed by Galich in Russia (see Introduction to Part IV, p. 176).

1836 В. П. Андроссов, „Ревизор, комедия в пяти Действнях, соч. Н. Гоголя” .Носковский наблюдатель. VII, 1 (1836).

. . . Комедия есть дело общественное. Это подвиг, это происшествие. Истинная комедия - это или исповедь или жалоба общества. И, смотря по тому, сколько она захватывает свонм влиянием общественных интересов. она - или подымается на степень истинной комедии, или делается просто зрелищем, более или менее забавным, с невинною целию занять праздное внимание и несколько праздных минут нашей жизни.

... Взглянувши так на комедню, мы найдем, что „Ревизор” есть явление. чрезвычайно важное в нашей словесности. Кто знает, как тяжело у нас добывается современность, тот будет уметь ценить труд Гоголя.

. . . Есть две драматические истины: истина действительного и истина возможного. Первая - когда берутся лица так, как они представляются наблюдательному вниманию в известное время, в известных отношениях, со всеми иддивидуальными свойствами своими. - это 
просто отрывок из жизни, повторяемый сценическим искусством. А потому здесь, как в подражании, чем более будет удержано сходства с подлинником, тем произведение будет выше, тем оно совершеннее. Тут материальная верность есть цель и мера успеха. Произведения этого рода то же самое в искусстве драматическом, что портрет в живописи.

. . . Сила этого рода таланта есть поразительное правдоподобие. и как сравнение вообще вещь нетрудная, то и достоинство этих талантов легче постигается и согласнее признается. В „Горе от ума" мы имеем образцовое произведение такого таланта. Другая драматическая истина истина возможного - глубже, реже встречается и еще реже увенчивается общим согласным успехом. Она не в том состоит, чтобы создать лица, составить правдоподобно действие, снять отпечаток действительной, моментной жизни общества, или, по крайней мере, не имеет всего этого исключительного в виду, - нет, она силится выразить сущности. или, как говорят, типы лиц, изобразить не то, что думал, говорил, или как действовал тот или другой, в том или другом положении, но то, что каждый из них по свойству своей природы мог и должен был бы чувствовать, мыслить, или как поступать в данных обстоятельствах. Тут не В том дело: действительно ли так было; но в том, так ли бы былю, если бы данные лища поставить в те соотношения. в каких автор их выводит на сцену.

Vasilii P. Androssov (1803-1841), statistician, became known by translating an essay on Kant's philosophy, published in Vestnik Evropy (1826). In 1828 he participated in editing the joumal Atenei. and in 1835 he was editor of the Moskorskii nabliudatel: The polemic concerning Gogol's comedy lasted from 1836 in to the 1840's. I. I. Panaev recalled in his Literaturnye vospominaniio that

". „Ревизор' Гоголя имел успех колоссальный, но в первыс минуты этого успеха никто даже из жарких поклонников Гоголя не понимал вполне значения этого произведения и не предчувствовал, какоЯ огромны персворот должен совершить автор этоя комедии. Кукольник после представления .Ревизора только иронически ухмылялся, и не отрицая таланта в Гоголе. замечал: .а все-таки это фарс. недостоиный искусства'. ...НовыЯ. свежия̆ дух уже веет в литературе."

1837 Н. В. Гоголь, „Петербургские записки 1836 года"

Современник, VI (1837).

Странное сделалось сюжетом нынешней драмы. Все дело в том, чтобы рассказать какое-нибудь происшествие, непременно новое, непременно странное, дотоле неслыханное и невиданное: убийство, пожары, самые дикие страсти, которых нет и в помине в теперешних обществах! Как будто в наши европейские фраки переоделись сыны палящей Африки! Палачи. яды - зффект, вечный зффект, и ни одно лицо не возбуждает 
никакого участия! Никогда еще не выходил из театра зритель растроганный. в слезах; напротив того, в каком-то тревожном состоянии торопливо садился он в карету и долго не мог собрать и сообразить своих мыслей. И среди нашего утонченного, образованного обшества такой род зрелища!

Gogol's criticism was directed against melodramas and vaudevilles, which were popular on the Russian stage. The vaudeville had first appeared in Russia in the early 1800's (A. A. Shakhovskoi). Young Griboedov, N. I. Khmel'nitskii, and A. I. Pisarev wrote vaudevilles between 1817 and 1825 . In the 1830's and 1840's the vaudeville became a popular genre reflecting many features of Russian life, often in a satirical vein. In the second half of the 19th century, the vaudeville all but disappeared from the Russian stage.

1840 В. Г. Белинскнй, „Горе от ума"

Отечественные записки. VIII, 1 (1840).

Разделение поэзия на три рода - лирическую, эпическую и драматическую - выходит из се значения как сознания истины и, следовательно, из взаимных отношений сознающего духа - субъекта, к предмету сознания - юбъекту: Лlирическая поэзия выражает субъективную сторо ну человека, открывает нашему взору внутреннего человека, и потому вся она - ощущение, чувство, музыка. Эпическая поззия есть объективное изображение совершившегося во времени события, картина, которую показывает вам художник, выбирая для нас лучшие точки зрения, указывая на все ее стороны. Драматическая поззия есть примирение этих двух сторон, субъективной, или лирической, и объективной, или эпической. Перед вами не совершившееся, но совершающееся событие; не поэт вам сообщает его, но каждое действующее лицо выходит к вам само, говорит за самого себя. . . .

Мы показали, что элементы трагического находятся в действительности, в положения жизни, так сказать; а элементы комического в призрачности, имеющей только объективную действительность, в отрицании жизни. Трагедия может быть и в повести, и в романе, и в позме, и в них же может быть комедия. Что же такое, как не трагедия, „Тарас Бульба" [Гоголя ] „Цыганы” Пушкина, и что же такое „Ссора Ивана Ивановича с Иваном Никифоровичем" [ Гоголя ] „Граф Нулин” Пушкина, как не комедия? . . . Тут разница в форме, а не в идее. . . .

Трагическое заключается в столкновении естественного влечения сердиа с идеею долга, В проистекающей из того борьбе и, наконец, победе или падения. Из этого видно, что кровавый конец тут ровно ничего не значит: Иван Иванович мог бы зарезать Ивана Никифоровича, а потом и себя, но комедия все бы осталась комедиею. . . . 
Обратимся к комедии, . . . она изображает отрицательную сторону жизни, призрачную деятельность. Как величие и грандиозность составляют характер трагедии, так смешное составляет характер комедии. Грандиозность трагедии вытекает из нравственного закона, осуществляющегося В ней судъбою ее героев, - людей возвышенных и глубоких или отверженцев человеческой природы, падших ангелов; смешное комедия вытекает из беспрестанного противоречия явлений с законами высшей разумной действительности. Как основа трагедии - на трагической борьбе, возбуждаюшей, смотря по ее характеру, ужас, сострадание или заставляющей гордиться достоинством человеческой природы и открывающей торжество нравственного закона. так и основа комедии на комической борьбе, возбуждающей смех; однако ж в этом смехе слышится не одна веселость. но и мшение за униженное человеческое достоиство, и, таким образом, другим путем, нежели в трагедии. но опять-таки открывается торжество нравственного закона. . . .

С 1823 года начала ходить по рукам публики рукописная комедия Грибоедова „Горе от ума”. Она наделала ужасного шума, всех удивила, возбудила негодование и ненависть во всех, занимавшихся литературою ex officio и во всем старом поколении; только немногие, из молодого поколения не приналлежавшие к записным литераторам и ни к какой литературной партии, были восхищены ею. Десять лет ходила она по рукам. распавшись на тысячи списков: публика выучила ее наизусть. враги ее уже потеряли голос и значение, уничтоженные потоком новых мнений, и она явилась в печати тогда уже, когда у ней не осталось ни одного врага, когда не восхищаться ею, не превозносить ее до небес. не признавать гениальным произведением считалось образцовым безвкусием. ...

ПІредставьте же себе, что комедня Грибоедова, во-первых, была написана не шестиногими ямбами с пиитическими вольностями, а вольными стихами, как до того писались одни басни; во-вторых, она была нагиясана не книжным языком, которым никто не говорил, которого не знал ни один народ в мире, а русские особенно слыхом не слыхали, видом не видали, но живым, легким разговорным русским языком; в-третьих, каждое слово комедии Грибоедова дышало комическою жизнию, поражало быстротою ума, оригинальностию оборотов, поззиею образов, так что почти каждый стих в ней обратился в пословицу или поговорку и годится для применения то к тому, то к другому обстоятельству жизни, - а по мнению русских классиков, именно тем и отличавшихся от французских, язык комедия, если она хочет прослыть образиовою. непременно должен был щеголять тяжелостию, неповоротливостию, тупостию, изысканностию острот, прозаизмом выражений и тяжелою скукою впечатления; в-четвертых, комедия Грибоедова отвергла искуственную любовь, резонеров, разлучников и весь пошлый. 
истертый механизм старинной драмы; а главное и самое непростительное в ней было - талант, талант яркий, живой, свежий, сильный, могучий . . . Да, литераторам не могла понравиться комедия Грибоедова; они должны были ожесточиться против нее! . . . За что же общество так сильно осердилось на нее? За то, что она была самою злою сатирою на это общество. Она заклеймила остатки XVIII века, дух которого бродил еще, как заколдованная тень, ожидая себе осинового кола, которым и было „Горе от ума”. Новое поколение вскоре не замедлило объявить себя за блестящее произведение Грибоедова, потому что вместе с ним оно смеялось над старым поколением, видя в „Горе от ума" злую сатиру на него и не подозревая в нем еще злейшей, хотя и безумышленной сатиры на самого себя, в лице полоумного Чащкого . . .

Итак, в комедии нет целого, потому что нет идеи. Нам скажут, что идея, напротив, есть, и что она - противоречие умного и глубокого человека с обществом, среди которого он живет. . . .

Очевидно, что идея Грибоедова была сбивчива и неясна самому ему, а потому и осуществилась каким-то недоноском. И потом: что за глубокий человек Чащкий? Это просто крикун, фразер, идеальный шут, на каждом шагу профанируюший все святое, о котором говорит. Неужели войти в обшество и начать всех ругать в глаза дураками и скотами - значит быть глубоким человеком? Что бы вы сказали о человеке, который, войдя в кабак, стал бы с одушевлением и жаром доказывать пьяным мужикам, что есть наслаждение выше вина - есть слава, любовь, наука, поэзия, Шиллер и Жан-Поль Рихтер? . . . Это новый ДонКихот, мальчик на палочке верхом, который воображает, что сидит на лошади . . . Глубоко верно оценил эту комедию кто-то, сказавший, что это горе, - только не от ума, а от у'мничанья . . .

Вообш் „Горе от ума" - не комедия в смысле и значении художественного создания, целого единого, особного и замкнутого в себе мира. в котором все выходит из одного источника - основной идеи, и все туда же возвращается, в котором поэтому каждое слово необходимо, неизменимо и незаменимо; в котором все превосходно и ничего нет слабого, лишнего, ненужного, словом - в котором нет достоинств и недостатков, но одни достоинства. Художественное произведение есть само себе цель и вне себя не имеет цели, а автор „Горя от ума" ясно имел внешнюю цель - осмеять современное общество в злой сатире, и комедию избрал пля этого средством. . . .

Но „Горе от ума” есть в высшей степени поэтическое создание, ряд отдельных картин и самобытных характеров, без отношения к целому, художественно нарисованных кистию широкою, мастерскою, рукою твердою, которая если и дрожала, то не от слабости, а от кипучего, багородного негодования, с которым молодая душа еще не в силах была совладеть. В этом отношении „Горе.от ума”, в целом, есть 
какое-то уродливое здание, ничтожное по своему назначению, какнапример, сарай, но здание, построенное из драгоценного паросского мрамора, с золотыми украшениями, дивною резьбою, изящными колоннами . . . И в этом отношении „Горе от ума" стоит на таком же неизмеримом и бесконечном пространстве выше комедии Фонвизина, как и ниже „Ревизора".

Грибоедов принадлежит к самым могучим проявлениям русского духа. В „Горе от ума" он является еще пылким юношею, но обещающим сильное и гпубокое мужество.

Belinsky's essay still reflects the influence of Hegelian philosophy which influenced the critic between 1837 and 1841 . His understanding of tragedy was also determined by the doctrines of German romantic thinkers. Belinskii defined the tragic in terms which reflect the views of Schelling and Schlegel (cf. Introduction to Part IV).

Conceming Griboedov's comedy, see above, p. 233.

$18+6$ И. С. Тургенев, „Смерть Ляпунова. Драма в 5-и действиях в прозе.

Соч. С. А. Гедеонова, СПб. 1846"

Отечественные записки. 8 (1846).

. . Нравственно-сатирические и исторические романы старого иокроя убиты; но исторические драмы существуют ... И потому-то мы должны заняться „Смертью Ляпунова” г. Гедеонова.

Исторический роман, историческая драма . . . Если каждого из нас так сильно занимает верное изображение развития самого обыкновенного человека, то какое впечатление должно производить на нас воспроизведение развития нашего родного народа, его физиономии, его сердечного, его духовного быта, его судеб, его великих дел? Вспомните драматизированные хроники Шекспира, „Геца фон Берлихинген”, романы Вальтера Скотта. . Кто решается - не смиренно и терпеливо пересказать судьбы своего народа. следуя современным бытописаниям. но в живых образах и лицах воссоздать свонх предков, избегнуть холода аллегорий и не впасть в сухой реализм хроники, действительно, представить некогда действительную жизнь, - тому мало даже большого таланта. если в сердие его не кипит русская кровь, если народ смV не близок и не понятен, прямо, непосредственно, без всяких рассуждений. пусть он лучше не касается святыни старины . . . Но великие дела тем и отличаются от малых, что они кажутся легкими для всех, хотя действительно легки для весьма немногих; оттого-то такое множество людей у нас и берется за исторические драмы. 
Gets fon Berlikhingen-Goetz von Berlichingen (1773), drama by the young Goethe. Walter Scott (1771-1832), Scottish poet and author of historical novels, widely imitated in Russia. Stepan A. Gedeonov (1816-1878), historian and writer, author of historical plays.

1847 Н. В. Гогољ, „Отрывкн из ,Авторской исповедн' "

С. П. Шевырев (изд.), Сочинения Н. В. Гоголя, найденные после смерти (Москва, 1855).

Если смеяться, так уж лучше смеяться сильно и над тем, что действительно достойно осмеянья всеобщего. В „Ревизоре” я решился собрать в одну кучу все дурное в России, какое я тогда знал, все несправедиявости, какие делаются в тех местах и в тех случаях, где больше всего требуется от человека справедливости, и за одним разом посмеяться над всем. Но это, как известно, пронзвело потрясающее действие. Сквозь смех, который никогда еще во мне не появлялся в такой силе, читатель услышал грусть. Я сам почувствовал, что уже смех мой не тот, какой был прежде, что уже не могу быть в сочиненьях моих тем, чем был дотоле и что самая потребность развлекать себя невинными, беззаботными сценами окончилась вместе с молодыми моими летами. После „Ревизора" я почувствовал, более нежели когда-либо прежде, потребность сочиненья полного, где бьлло бы уже не одно то, над чем следует смеяться. 


\section{PROSE}

1793 М. М. Карамзин, „Кадм н гармония (Хераскова)”

Московский журнал, 2-ое изд., (1803)

(цитата из Северного вестника. III, 8 [1804], стр. 141-158).

. . . но когда повесть есть не история, а вымысл, то она, кажется, есть

поэма - эпическа или нет, но все поэма - стихами или прозою писанная, но все позма, которая пообщепрннятому понятию на других языках означает всякое творение вообразительной силы. Таким образом комедия, роман есть поэма.

The distinction between historically truthful accounts and imaginary events in fiction was an important one. The 18th century called the latter "skazka" or "romany" and was liable to look down upon them. Sumarokov, Kheraskov, and Lomonosov condemned novels. It was only in the 1760's and 1770's that fiction became a major genre in Russian literature. English and French novels by Richardson, Sterne, Fielding, Defoe, Prevost, Arnaud, Mercier and others prepared the way. Towards the end of the century, it was especially Sterne (Sentimental Journey). Goethe (The Sufferings of Young Wer. ther). Mme de Stael (Delphine and Corinne), and Chateaubriand (René. Atala) who became influential in Russia. The imaginary travel, based on $X$ de Maistre (Voyage autour de mo chambre, 1794; translated 1802), and the Gothic novel of Mrs. Radcliffe were further powerful influences on Russian prose in the early 1800's. In all these works the lyrical element was strong and justified the application of the term poem. The trend to see in poetry the highest art form, to endow all other genres with lyrical, poetic features, became an important characteristic of romantic literature. See also, p. $175 f$.

-- , ,О сказках и романах"

Aвpopa. 11 (1805).

Цель романа состоит в том, чтобы изобразить человєка и явле:няя прсисходящие в душе его...

Во всех сих случаях романист предполагает себе цель психологическую или антропологическую.

The sentimental trend had led to an increased emphasis on the individual and his emotional responses. As a consequence. there developed a greater interest in psychology in literature which is noticeable in all genres. The analysis of emotions and passions became the main theme of the early romantic novels of Goethe, Mme de Stael, and Chateaubriand (see above). The anonymous author of the above text divided novels into three groups: (1) novels which depicted the heart in all truthfulness with all its passions (as in the works of Wieland, Fielding, and Sterne); (2) novels which described one main trait of the heart, e.g., love (as in the works of Rousseau); (3) novels which exposed 
a ruling vice or folly (as examples the critic mentioned Cervantes and Goldsmith). Above all, the anonymous author stressed psychological truth, and the inner logic of contemporary novels.

1810 ---, [Крнтика]

Вестник Европы, LI (1810), стр. 72 и далее.

Мои Петербургские сумерки (Ник. Страхова) составлены из отделенных под разными заглавиями статей: сентиментальных, сатирических, топографических, исторических и моральных. Не ищите в них ни взаимной между собой связи, ни плана, ни последовательного порядка. От Надежды внезапный переход к Осени, от Осени к Невской улиие, от Фейерверков к Обелиску Румянцева, от Переплетчика к Памятнику Суворова. от Кондиторов к Потемкину, от Городской полночи к Ивану Великому и т. д.

The novel appeared in various forms. Apart from the "psychological" novel of the type of Goethe's Werther, or the novels by Mme de Stael and Chateaubriand which were extremely popular during the first decade of the 19th century in Russia, there was the Gothic novel (Mrs. Radcliffe), the German Räuber- und Schauerroman (Spiess, Zschokke, et al.)-all of which were widely translated and imitated-the travelogue, and essayistic prose. The travelogue appeared in two forms, as an account of an actual journey (the model for this type was Dupaty's Lettres sur l'Italie en 1785, 1788; translated by I. Martynov 1800-1801), and as an account of a sentimental joumey on the pattern of Steme's novel. The lat ter form was continued by Xavier de Maistre's imaginary journey, Voyage autour de ma chambre (1794, translated 1802), and his numerous imitators in France and Russia. Karamzin's Letters of a Russian Traveler were widely imitated in Russia. Apart from travelogues, there existed popular collections of essayistic prose, such as Mercier's Songes philosophiques (translated 1780-1781), Mon bonnet de nuit (1783; translated 1784), and his monumental Tableau de Paris (1781-1788; translated 1786). The loose form of sketches on various themes appealed to the romantic imagination. Strakhov's collection continued this form which was defined as "romantic" by a Russian reviewer in 1806 who said of Jean Paul (who wrote in a similar style), "он пишет романические сочинения. в которых содержание и происшествия почти ничего не значат, н служат только к соединению множества отрывков хороших и худых, замысловатых и простых, высоких и площадных, оригинальных и обыкновенных" (Лицей. III, 3 [1806], р. 91).

Apart from the authors and subgenres mentioned above, one should not forget the many popular sentimental novels of Mme Genlis which were read widely at the time. 
Полное собрание сочинений, XI (1949).

Д’Аламбер сказал однажды Лагарпу: не выхваляйте мне Бюфона, [этот человек ] пишет: „Благороднейшее изо всех приобретений человека было сие животное, гордое, пьлкое и проч." Зачем просто не сказать лошадь? - Лагарп удивляется сухому рассуждению философа. Но д’ Аламбер очень умный человек - и, признаюсь, я почти согласен с его мнением.

Замечу мимоходом, что дело шло о Бюфоне - великом живописце природы. Слог его, цветуший, полный, всегда будет образцом описательной прозы. Но что сказать о наших писателях которые, почитая за низость объяснить просто веши самые обыкновенные, думают оживить детскую прозу дополнениями и вялыми метафорами? Эти люди никогда не скажут дружба, не прибавя: „Сие священное чувство, коего благородный пламень и проч." - Лопжно бы сказать: „Рано поутру”, - а они пишут: „Едва первые лучи восходящего солнца озарили восточные края лазурного неба"; - ах, как зто все ново и свежо, разве оно лучше потому только, что длиннее? . . .

Точность и краткость - вот первые востоинства прозы. Она требует мыслей и мыслей - без них блестяшие выражения ни к чему не служат; стихи - дело другое (впрочем, в них не мешало бы нашим поэтам иметь сумму идей, гораздо позначительнее, чем у них обыкновенно водится. С воспоминаниями о протекшей юности литература наша далеко вперед не поввинется).

Вопрос, чья проза лучшая в нашей литературе? - Ответ: Карамзина. Это еще похвала не большая - скажем несколько слов об сем почтенном. . . .

In the 1820's, prose was replaced by poetry as the leading genre. The above text shows Pushkin groping for a new prose style which was subsequently realized in his tales of the 1830 's.

D'Alamber-Jean le Rond d'Alambert (1717-1783), mathematician and writer, an editor of the Encyclopédie (1751-80); Lagarp-Jean Francois de La Harpe (1739. 1803); Biufon-Georges Louis Leclerc de Buffon (1707-1788).

1825 П. А. Вяземскиһ̆, „Письмо в Парно“ Московский телеграф. VI, 22 (1825).

Не удовлетворяя вполне зстетическим требованиям искусства, Нарежный победил первый, и покамест один, трудность, которую, признаюсь, почитал я до него непобедимою. Мне казалось, что наши нравы, что 
вообще наш народный быт не имеет мало оконечностсй живописных, кои мог бы охватить наблюдатель для составления русского романа. Правда, что автор наш наблюдатель не совершенно русский, а малороссийский и что два его лучшие романа: „Бурсак” и „Два Ивана” относятся к эпохе, когда Малороссия еще имела свою особенную и характеристическую физиономию; правда и то, что Нарежный не берется быть живописцем природы изяшной, а сбивается более на краски Теньера или Гогарта или Пиго. Картины его имеют обыкновенно черты карикатурные, но не менее того обнаруживается везде ум оригинальный, веселый, сметливый в наблюдениях, а кое-где и прорываются искры истинной чувствительности. Он не дает читателю в первых страницах романа отгадать загадку, которая становится утомительною, когда любопытство удовлетворено прежде-временно; но он довольно искусно заводит читателя и при конце дает отчет ясный и сбыточный. Не все романисты поступают так добросовестно с читателями своими. Жаль, что язык неприятный, грубый, иногда даже дикий, вкус неочищенный, или - справедливес - совершенное отсутствие вкуса, много вредят достоинству сих романов; но со всем тем они занимают место в числе замечательных произведений нашей ленивой и малоурожайной словесности.

Ten'er-David Teniers (1582-1649), Flemish artist; Cogart - William Hogarth (16971764), English painter and engraver; Pigo-Pigault-Lebrun (1753-1835), French novelist, popular in Russia.

Vasilii Trofimovich Narezhnyi (1780-1825) published his first prose work in 1809 (Slavenskie vechera; a collection of romantic sketches from Russia's distant past). His novels depicted Russian life and manners. They were Rossiiskii Zhilblaz, ili Pokhozhdeniia kniazia Gavrily Simonovicha Chistiakova (1814), Chernyi god, ili Gorskie knaz ia (1818), Ariston, ili Perevospitanie (1822), and three novels from Ukrainian life, Bursak, Zaporozhets, and Dva Ivana. They exerted a definite influence on Gogol's tales.

1826 П. А. Вяземский, „Записки графнни Жанлис. Париж, 1825 года” Полное собрание сочинений, I (Санкт-Петербург, 1878).

Наш век есть, между прочим, век записок, воспоминаний, биографий и исповедей вольных и невольных: каждый спешит высказать все, что видел, что знал, и выводить на свежую воду все, что было поглощено забвением или мраком таинства.

J. J. Rousseau's Confessions (1781; translated 1797) began an almost endless stream of literature devoted to lyrical accounts of individual emotional experiences. Viazemskii himself contributed to this genre with his transiation of Benjamin Constant's autobiographical novel Adolphe, anecdote trouve dans les papiers d'un inconnu (1816; translated 1837). 
1828 В. П. Титов, „О романе как представителе образа жизни новейших европең̆щев"

Московский вестник, VII, 11 (1828).

Роман, преимущественно пред другими родами сочинений, пользуется всеобщей любовью и потому действует сильнее на народные нравы.

... На чем же основано неодолимое влияние, которое сии книги, сколько во вред, столько и в пользу, имеют уже в продолжение веков на наши души. Вопрос равно занимательный и важный. На том отвечаю, что сей род сочинений согласнее всех других с нашими обычаями, духом и господствующим направлением ума.

. . . Это единственный род, пребывший свободным от подражания древним и сохраняюший все признаки образа мыслей и способа изложения чисто новейшего.

. . . Определим во всей строгости черты, составляющие его характер. Сии черты немногочисленны: хотя с первого взгляда творения сего рода представляют бесконечное разнообразие характеров, приключений. завязок, игры случаев; но вся пестрота сих изобретений приводится к двум предметам, которые можно назвать постоянными производителями романа. потому что в каждом романе повторяются. Сии два предмета - любовь и описание семейственной жизни. Иногда любовь, как в Новой Элоизе, составляет главное; иногда служит она только основою в ткани повествования, как во многих творениях В. Скотта. Несмотря на сии изменения и насмешки, заслуженные иными романистами от критиков, должно сказать без исключения, что роман без любовной завязки существовать не может. Описание домашней жизни есть другая, до того необходимая стихия, что когда романист покидает область любви и чувства, тогда его внимание неизбежно приковывают мелочные подробности об увеселениях, обычаях, способах поддерживать бытие телесное, употребительных в том уголке земного шара. где расположена сцена повествования. Сии подробности драгоценны для наблюдателя и друга человечества.

. . - Бедствия, встречаемые в таких обстоятельствах, состоят большею частью из приключений маловажных по причинам своим, хотя и решительных для участи человека по последствиям. Оттого и в романе судьба не выстувает в явную борьбу с героем, как напр. в трагедии, но, как бы невидимо, запутывает его в сеть неприятных случаев. - Важнейшая и лучшая эпоха в нравственном развитии частного человека есть любовь. . . И. Итак, не удивительно, если писатели романов, желая как можно живее изобразить человека в частной жизни, выбирают именно ту пору, когда пламенник любви освещает его душу.

. . . Ни одно творение поэзия так верно, как роман, не представляет духа той земли, где написано. . . . 
V. I. Titov, a member of the Moscow circle of liubomudry (see above, p. 131), defined the novel according to German romantic esthetics as the central genre of literature. A. Schlegel had defined the novel as "the point where literature touched upon bife in greatest immediacy" Athenäum, no. 149). His brother Friedrich called the novel "a compendium of the whole spiritual life of an individual of genius." The novel was understood to contain a universal mythology, an ordered chaos, which permitted unlimited play with the irrational.

1829

---, „Современная библиография. Русская литература" Московский телеграф. VI (1829).

-Юрий Милослевский, или русскне в 1812 году.

Соч. М. Н. Загоскина.

Извешая читателей наших о скором появлении исторического романа, сочиненного Ф. В. Булгариным, мы сказали, что Дмитрий Самозванеи будет первый, по времени появления своего в свет русский исторический роман. Теперь, честь сия принадлежит роману, сочиненному М. Н. Загоскиным.

... Юрий Милославский роман совсем в роде В. Скоттовых. Если-бы надобно было искать образца, по которому он создан, то мы скорее могли-бы найти его в романах Купера.

The historical novel began in Russia with the above-mentioned two novels by Zagoskin and Bulgarin. The model had been provided by numerous translations of historical novels by Walter Scott, one of the most popular authors in Russia in the second half of the 1820 's. Bulgarin had borrowed liberally from published scenes of Pushkin's drama Boris Godunov.

Kuper-James Fenimore Cooper (1789-1851) was popular in Russia in the late 1820's and throughout the 1830's. The Spy (Shpion) was translated and printed in 1825; Prairie (Amerikanskie stepi) was published in 1829; The Pilot (Lotsman) appeared in translation in 1832. At this time, Cooper's fame had been established firmly in Russia. The same year, his Pioneers (Pionery) and The Red Rover (Krasnyi morskoi razboinik) were published in Russia, followed by The Last of the Mohicans (Poslednii iz Mogikan) in 1833, and Bravo (Bravo) in 1839. The Path finder (Sledopyt) followed in 1841. Cooper's novels were highly acclaimed by Belinskii. The joumal Moskouskii telegraf popularized the American writer in the 1820's and 1830's.

Mikhail N. Zagoskin (1789-1852) had started as a journalist and au thor of comedies. In the late 1820 's he turned to the historical novel and, together with Ivan Lazhechnikov (1792-1869), became Russia's major historical novelist of the first half of the 19 th century.

---, [Сочннення Бударарина. Иван Выжягин. 1829 ] Московский телеграф. IV (1829).

В кабинетах, в гостиных, на бирже, в городах, в деревнях, в целой России сочинения r-на Булгарина, и особенно Иван Вьцсигин, составляют предмет разговоров. Просвешенные и невежды, умные и неразумные, 
дамы, старики, офицеры, купцы, чиновники, даже девушки и дети толкуют о Булгарине, о его успехах литературных. . . .

Сатирические описания нравов родились в Англии. . . .

Честь и славу r-ну Булгарину, что он первый решился испытать скл своих у нас в наблюдении нравов . . .

Говорят, что он односторонен, повторяет всегда одно и то же, и что все его описания нравов кружатся вокруг одной общей всем аксиомы: надобно делать добро и избегать всего дурного.

В Вымигине много несовершенного, лишнего и недосказанного, но, прибавляем, это самое громкое и блестящее явление в современной нам прозаической словесности русской где все спят спокойным сном.

Faddei Bulgarin (1789-1859), a conservative journalist, editor of the journal Severnaia pchele (1825-1859), was also a major representative of the satirical novel of manners. His novels had little literary merit. A review in the almanac Dennitse (1830) said that Ivan Vyzhigin was characterized by "lazyk bolee gladkii, khotia bestsvetnyi i vialyi. . . Pustota, besvkusie, bezdushnost', nravstvennye sententsii, vybrannye iz detskikh propisei, nevernost' opisanii, pritomost' shutok. .." However, Bulgarin's novel was received well by the Russian reader. For the first time, a Russian writer had reproduced the life of provincial bureaucracy and landowners with great exactitude and a sense of reality. The considerable success of the novel prompted Bulgarin to write a sequel, Petr Ivanovich Vyzhigin (1831), which related the life of the son of the original Ivan Vyzhigin. A third novel of the same type. Posmertnye zapiski tituliarnogo sovernika Chukhina. appeared in 1835. Bulgarin's novels could be considered the link between Narezhnyi's novels and Gogol's novel Dead Souls.

1830 С. А., [ Рецензия на книту Юрй Милославский, или Русские в 1612 году. Исторнческий роман в 3-х частях. Сочннение М. Н. Загоскина . . . Москва . . . 1829 ]

Московский вестник, I-II, 159 (1830).

Радуясь прекрасному явлению в литературе нашей, как общему добру, мы с большим удоволствием извещаем читателей, что наконец словесность наша обогатилась первым историческим романом, первым творением в этом роде, которое имеет народную физиономию: характеры, обычая, нравы, костюм, язык. . . .

Это небывалое явление на горизонте нашей словесности: романы Нарежнего хотя показывают некоторое дарование в сочинителе, но выполнены слишком дурно во всех отношениях; в других новых наших романах нет ничего национального, русского.

See also, pp. $248 f ., 251$. 
1830 А. С. Пушкин, „Юрнй Милославский, или русскне в 1612 году” Литературная газета, 5 (1830).

Г-н Загоскин точно переносит нас в 1612 год. Добрый наш народ, бояре, козаки, монахи, буйные шиши - все это угадано, все это действует, чувствует, как должно было действовать, чувствовать в смутные времена Минина и Авраамия Палищына. Как живы, как занимательны сцены старинной русской жизни! Сколько истины и добродушной веселости в изображении характеров Кирши, Алексея Бурнаша, Федьки Хомяка, пана Копычинского, батьки Еремея! Романическое происшествие без насилия входит в раму обширнейшую происшествия исторического. Автор не спешит своим рассказом, останавливается на подробностях, заглядывает и в сторону, но никогда не утомляет внимания читателя. Разговор (живой, драматический везде, где он простонароден) обличает мастера своего дела. Но неоспоримое дарование r. Загоскина заметно изменяет ему, когда он приближается к лицам историческим. Речь Минина на нижегородской площади слаба: в ней нет порывов народного красноречия. Боярская дума изображена холодно. Можно заметить цва-три легких анахронизма и некоторые погрешности противу языка и костюма Например, новейшее выражение: столбовой дворянин употреблено в смысле человека знатного рода (мужа честна, как говорят летописшы) ; охотиться вместо ездить на охоту; пользовать вместо лечить. Эти два последние выражения не простонародные, как, видно, полагает автор. но просто принадлежат языку дурного общества. Быть в ответе значило в старину: быть в посольстве. Некоторые пословишы употреблены автором не в их первобытном смысле: из сказки слова не выкинешь вместо из песни. В песне слова составляют стих, и слова не выкинешь, не испортив склада; сказка - дело другое. Но сии мелкие погрешности и другие, замеченные в 1 № Московского вестника нынешнего года, не могут повредить блистательному, вполне заслуженному успеху ..Юрия Милославского" ....

В наше время под словом роман разумеем историческую эпоху, развитую в вымышленном повествовании.

Pushkin himself had been studying archival material for his own historical tales (especially Kapitanskaia dochka). His concern for historical truthfulness and accuracy is noteworthy. 
1831 Н. И. Надежкин (?), „Рославлев, или Русские в 1812 году (М. И. Загоскнна). Крнтика"

Телескоп, IV (1831).

Нет никакого сомнения, что роман составляет не прихоть, а потребность современного возраста творческой деятельности. . . .

Общее мнение дает поныне роману значение фантастического сцепления необыкновенных происшествий и не отличает его от сказки ничем, кроме большей сложности в составе, и искусственности в обработке и занимательности в содержании.

. . . Иногда . . . роману поставляется в необходимую принадлежность известный дозис сентиментальности. Этот новый оттенок преимущественно имеет место при выражениях; романический, романическое. Таким образом в действиях признается романическое, когда они основываются не на холодных расчетах благоразумия, а повинуются безотчетно внушениям сердца; п потому каждое происшествие, соверщающееся под влиянием любви, сей верховной царищы чувств, считается в высшей степени романическим.

Мы сказали, что роман, по нынешнему понятию, не принадлежит ни к эпической. ни к лирической, ни к драматической поззии, а есть общая их иелость. ...

Для современной поззия - долженствующей представлять человека и природу в тех отношениях политического равновесия, в коих они состоят действительно, - драматическая форма должна быть самою удобною. Но ее подчинение сценическим условиям не представляет фантазии довольного простора, в коем она могла б свободно разбрасывать свои вольные картины безбрежного океана жизни. Потребны были рамы гораздо обширнейшие; и Вальтер Скотт угадал их. В них оправлены все его творения, известные под именем романов.

В силу . . . . тесного внутренного общения со всеми тремя родами поэзии роман Вальтера Скотта присвоет себе полную свободу принимать и наружные формы всех их без различия. Ему равно дозволяются и эпическая форма рассказа, и лирическая форма разгявора.

. . . Он есть та же история, - но отраженная не в прямом, а искусственно устроенном зеркале, где явления сохраняют свою физиономию и цвет, но переменяют относительное положение свое друг к другу, для образования цельной картины, сообразной с предположенною идеею.

В этом смысле понимаемый роман составляет общую потребность нашего века, коей он не может стыдиться.

. . . Роман есть представление жизни в действиях: его душу должно составлять движение. Но движение предполагает волнение и игру страстей: и потому жизнь тем способнее для романа, чем мятежнее и кипучее. . . . Но в русской народной жизни, переливающейся так медленно и однообразно, много ли сыщется тайн, коих исповедь могла б 
иметь романическую занимательность? Если в высших слоях нашей общественной атмосферы примечаются некоторые движения, то они пронзводятся чужими прививными понятиями, чужими наносными страстями: это не материалы для народного русского романа! Опускайтесь ниже: вы начнете различать черты физиономии оригинальной, живописной, поэтической, но - окованной неподвижностью, не оживленной игрой страстей, и, следовательно, лишенной романического рельефа. В наших средних и низших сословиях, где дух русский сохраняется чище и неповрежденнее, вся жизнь обыкновенно бывает не что иное, как многолетнее повторение одного дня. ...Коротко сказать - обыкновенной жизни русской не достанет на одку порядочную главу романа!

Nadezhdin defines "romanicheskii" in the manner of early romantic literature of the first decade of the 19th century. His view of the novel as the most adequate genre with the widest range of stylistic devices corresponded to romantic theory. F. Schlegel had said in his Brief uber den Roman. "I can hardly think of the novel other than as a mixture of narrative, song, and other forms." A. Schlegel likewise had pointed to the close relationship of dramatic and epic genres.

1832 ---, „Современные летопнси. Повести Миханла Погодина . . . Вечера на хуторе близ Диканьки ..."

Tелескоп, XI, (1832).

. . . Повесть считается теперь делом совместным со всеми направлениями деятельности, со всеми степенями ума, со всеми родами гения.

. . . ІІовесть принадлежит к категории романа. Она есть и должна

быть не что иное, как одушевленный рассказ происшествий, поэтическое представление жизни. От романа она отличается только объемом . . . - роман в миниатуре!

. . Ж Жизнь человеская слагается из трех элементов: мыслей, действий и чувствований следовательно . . . излияние чувств, . . . выражение мыслей, . . . сцепление действий.

... Повести бывают троякого рода: философическиё, сентиментальные и собственно дееписательные.

Pogodin's first novella, Nishchii, appeared in 1826 together with another, Kak auknetsia, tak i otkliknetsia. It was followed by Chemaia nemoch' in 1829. His novellas prepared the ground for Pushkin's and Gogol's novellas of the 1830's. Gogol's Vechera na khutore bliz Dikan 'ki appeared in 1831 . 
1832 Н. И. Надеждин, „Летопнси отечественной словесности” Телескоп, Х, 14 (1832).

Роман, как понимает его теперь Европа, должен представить полную картину жизни, в ее деятельном развитии, строго подчиняясь всем вещественным условиям истины, но мехху тем предоставляя себе свободный выбор и устроение занимательных точек зрения. Посему он есть та же история, только отрахенная не в прямом, а искусственно устроенном зеркале, где явления сохраняют свою физиономию и ивет, но переменяют относительное полохение свое друг к другу, дяя образования цельной картины, сообразно с предположенною идеею. . . .

И роман, как поэзия историн, должен быть картиною жизни минувшей, изображением прошедшего.

Современность только может быть доступна для исторического воспроизведения и романической обработки, когда, всдедствие внезапных, насильственных переломов жизни, нити, соединяющие настоящее с ближайшими предыдушими моментами, разрываются. Так, в нынешней Франции, где беспрестанное колебание отторгает вчера от ныне. гдє события не рождают, а выкидывают друг друга, современное слишком скоро сбрасывается со сцены настоящего и отходит в область прошедшеrо, в заведывание истории и романа.

. . Кажется, не ошибаемся, сказав, что без Шекспира не существовал бы В. Скотт. Он понял тайну, как изображал Шекспир историю в драмс. Человек как он есть; роман как изображение того, что допускает возможным история; верное изображение народности; местная декорация нравов и обычаев - вот основание романов В. Скотта.

Такой роман современники единогласно признали открытием нашего века.

. . . Само по себе разумеется, что из сего ужё выводятся условия форм, в какие облекаются романтические творения, и если сии формы удовлетворяют истине и полноте - мы ничего более от них не требуем. В романткзме предмет определяет форму, а в классииизме форма определяет предмет.

1833 А. Марлинскии (А. А. Бестужев), „О романе Н. Полевого „Кяятва при гробе Господнем'"

Московский телеграф, LIII, 15-18 (1833).

. . . В полдюжины лет нажили мы не одну дюжину романов, подснежных, пудовых романов, романов, в которых есть и русский квас и русский хмель; есть прибаутки и пословищы, от которых не отказался бы ни один десятский; есть и лубочные картинки нашего быта, 
раскрашенные матушкой грязью; есть в них все, кроме русского духа, все, кроме русского народа!

. . . Несмотря на многочистенность наших романов, не смотря на запрос на романы, едва ль не превышаюший готовность составлять их, несмотря на одобрение властей, мы бедны, едва ль не нищи оригинальными пронзведениями сего рода.

Отчего это?

. . . Роман . . . есть не что иное, как позма и драма, лиризм и фплософия и вся поззия в тысяче граней своих, весь свой век на обе корки. Древние не знали романа, ибо роман есть разложение души, история сердца, а им некогда было заниматься подобным анализом; они так были заняты физическою и политическою деятельностью, что нравственные отвлеченности мало имели у них места.

. . . Карамзин заохотил нас к преданиям нашей старины; археологические попытки собрали кой-какие элементы для романа. Исторические повести Марлинского, в которых он, сбросив путы книжного языка, заговорил живым русским наречием, служили дверьми в Хоромы, полного романа . . . Любопытство было напряжено тем сильнее, что Пушкин только дразнил его главами „Онегина”, что на театре не было ничего, кроме битых-перебитых водевилей с французского, только из учтивости называемых двусмысленными. И вот выискался, наконец, человек, который решился прыгнуть в разверстую пасть крокодила публики. Это был Булгарин. . . .

Г-н Булгарин исполнил этот подвиг так же удачно, как смело. Зависть, возбужденная его „Дмитрием Самозванцем", доказала, что В нем были достоннства; но скажу правду: в нем он подарил нас европейским, не русским романом. Труд его, конечно, заслуживает одобрение современников. но едва ль врежется в память потомства, оттого что автор не постиг духа русского народа. Не Русь, а газетную Россию изобразил нам он. . . . Русские едва видны, и то они теряются в возгласах или падают в карикатуру.

.. . Явился Загоскин, и с первой попытки догнал Булгарина, хотя он далеко не оправдал заносчивых титулов своих романов: Милославский, или Русские в 1612 году, Рославлев, или Русские в 1812 году! Неужели три-четыре черты составить могут картину? Неужели пара помешиков, да пары две офицеров, да один уголок траншеи под Данцигом могут дать полное понятие о русских, о войне громового 1812 года? Помилуй Бог! В истине мелких характеров и быта Руси он превзошел автора „Самозванца”, нисколько во взгляде на события. Притом чужеземная подделка не спряталась ұ него под игривостью русского языка. Его Юрий - метампсихоза Вальтера Скоттова Веверлея. Его поп-партизан - испанский Эмпечинадо, его Зарядьев - капитан из романов Купера. 
. . . Один только сочинитель „Последнего Новика", несмотря на прыгучий слог свой и на двойную путаницу завязки, умел стать самобытным, умел избежать укора за вербовку подробностей исторических, оживив их горячею игрою характеров.

. . . Между тем как Пушкин воздвигал пирамиду в пустыне нашей поэзии, я говорю об его „Годунове”, Н. Полевой, который с такнм пылким самоотвержением посвятил себя правде и пользе русского просвещения . . . издал три тома своей Истории русского народа. . . Ему вспало на ум: досказать русскую историю - повестью, ознакомить нас с домашним бытом предков наших без прикрас, так сказать, показать подбой княжеской мантии, распоясать крестьянина, растворить ум и сердце русского народа и застать там причину событий в едва заметном зерне . . . Вследствие этого он написал сперва повесть „Симеон Кирдяна” и теперь „Клятву при гробе Господнем”, русскую быль XV века.

. . . Вельтман, чародей Вельтман, который выкупал русскую старину в романтизме, доказал, до какой обаятельной прелести может довести русская сказка, спрыснутая мыслию. Да, песня и сказка - душа русского народа: он веселится и горюет с песнею, засыпает под говор сказки.

Alexander Bestuzhev-Marlinskii (1797-1837), published his furst historical tale, Poezdko $v$ Revel', in 1821. Other novellas followed: Zamok Neigauzen (1824), Revel'skii turnir (1825), Roman i Ol'ga (1823), Izmennik (1825), and Listok iz dnevnika guardeiskogo ofitsera (1823). After arrest and imprisonment for his participation in the Decembrist uprising, he continued writing prose novellas. He became famous with his tales and novellas in the 1830's when he served in the Caucasus and wrote on Caucasian themes (e.g., Ammalat-bek, 1832; Mulla-nur, 1836). His arch-romantic style, the high ideals of his heroes, and their adventures in one of the most romantic landscapes, made the author one of the best-loved prose writers of the time.

Val'ter Skortov-Veverlei-the novel Waverley (1814) by Walter Scott. Bulgarin's historical novels Dmitrii Samozvanets (1830) and Mazepa (1834) were of little literary merit and had hardly any influence on the subsequent history of the genre.

Ivan Lazhechnikov (1792-1869) is known for three widely popular historical novels which depict the grow th of Russia to a powerful state: Poslednii novik (1833; set at the time of Peter the Great); Ledianoi dom (1835; the time of Empress Anne); and Basurman (1838; set in the 16th century).

Nikolai Polevoi (1796-1846), editor of the journal Moskovskii telegraf (18251834), defended the romantic movement in his journal, and himself wrote several romantic novellas and novels (Emma. 1829; Kliatva pri grobe Gospodnem. 1832; Abba. donna, 1834, and others).

Alexander Vel'tman (1800-1870) began to write poetry in 1828. His novel Strannik appeared in 1831-1832. This was followed by a series of historical and fantastic-u topian novels which made Vel'tman the most popular prosewriter of the 1830's. 
. . . Вы создаете нечто новое, Вы начинаете новую эпоху в литературе, которую уже прославили в другой отрасли . . . Вы положили начало новой прозе, можете в этом не сомневаться . . . Именно всеобщего русского языка недоставало прозе, и его-то я нашел в вашей повести.

Pushkin's tales appeared in the early 1830 's, but were met coolly by the public. 0 . I. Senkovskii, the editor of the journal Biblioteke dlia chteniia, was one of the few critics to recognize the significance of Pushkin's prose style.

1835 В. Г. Белинския, „О русской повести и повестях г. Гоголя” Телескоп. XXVI (1835).

. . . В нашей литературе господствующими родами поэзии сделались роман и повесть, и сделались . . . не столько вследствие слепого подражания или преобладания какого-нибудь сильного дарования, или, наконец, обольщения слишком необыкновенным успехом какогонибудь творения, сколько вследствие общей потребности и господствующего духа времени....

Повесть наша началась недавно, очень недавно, а именно - с двадцатых годов текущего столетия. До того же времени она была чужеземным растением, персвезенным из-за моря по прихоти и моде и насильственно пересаженным на родную почву. Может быть, поэтому она и не принялась. Карамзин первый, впрочем с помощию Макарова, призвал зту гостью, набеленную и нарумяненную, как русская купчиха, плаксивую и слезливую, как избалованное дитя-недотрога, высокопарную и надугую, как классическая трагедия, скучно поучительную и приторно нравственную, как лицемерная богомолка, воспитанницу мадам Жанлис, крестницу добренького Флориана. К такому роду повестей принадлежат все повести, писавшиеся до двадцатых годов, да их, к счастию, и не много было написано: „Марина роща" Жуковского, несколько повестей покойного В. Измайлова и . . п право, не помню, какие еще.

В двадщатых годах обнаружились первые попытки создать истинную повесть. Это было время всеобщей литературной реформы, явившейся вследствие начинавшегося знакомства с немецкою, английскою и новою французскою литературами и с здравыми понятиями о законах творчества. Если повесть не оказала тогда настоящих успехов, по крайней мере обратила на себя всеобщее внимание по своей новости и небывалости. Чтобы не говорить много, скажу, что г.Марлинский был первым нашим 
повествователем, был творцом или, лучше сказать, зачиншиком русской повести.

. . . Может быть, роман удобнее для позтического представления жизни. И в самом деле, его объем, его рамы до бесконечности неопределенны; он менее прихотлив, нежели драма, ибо, пленяя не столько частями и отрывками, сколько целым, допускает в себя и такие подробности, такие мелочи, которые при всей своей кажущейся ничтожности, если на них смотреть отдельно, имеют глубокий смысл и бездну поззии в связи с целым в обшности сочннения.

Но повесть? Ее значение, тайна ее владычества, теперь деспотического, своенравного, не терпящего соперничества? . . . Когда-то и где-то было прекрасно сказано, что „повесть есть эпизод из беспредельной поэмы судеб человеческих". Это очень верно; да, повесть - распавшийся на части, на тысячи частей роман; глава, вырванная из романа. . . Ж Жизнь наша, современная, слишком разнообразная, многосложна, дробна: мы хотим, чтобы она отражалась в поззии, как в граненом, угловатом хрустале, миллионы раз повторенная во всех возможных образах, и требуем повести. Есть события, есть случаи, которых, так сказать, не хватило бы на драму, не стало бы на роман, но которые глубоки, которые в одном мгновении сосредоточивают столько жизни, сколько не изжить ее и в века: повесть ловит их и заключает в свои тесные рамки. Ее форма может вместить в себя все, что хотите, - и легкий очерк нравов, и колкую саркастическую насмешку над человеком и обществом, и глубокое таннство души, и жестокую игру страстей. Краткая и быстрая, легкая и глубокая вместе, она перелетает с предмета на предмет, дробит жизнь по мелочи и вырывает листки из великой книги этой жизни. . . .

Отличительный характер повестей г. Гоголя составляют - простота вымысла, народность, совершенная жизнь, оригинальность и комическое одушевление, всегда побеждаемое глубоким чувством грусти и уныния. Причина всех этих качеств заключается в одном источнике: г. Гололь поэт, поэт жизни действительной.

Zhanlis-Stéphanie-Félicité Ducrest de Saint Aubin Marquise de Sillery, Comtesse de Genlis (1746-1830), wrote numerous sentimental, moralistic essays, tales, novels, and plays, of ten with a didactic aim, which dealt with contemporary society and were very popular in Russia around the turn of the century. Florion-Jean-Pierre Claris de Florian (1755-1794), author of idylic, pastoral novels, sentimental comedies, songs, and fables. V. V. Izmailov (1773-1830), minor author of tales in the sentimental taste. He was considered one of the best imitators of Karamzin's style. Most of his work appeared between the end of the 18th century and 1815. M. N. Makarov (1789-1847), collector of folklore, editor of Zhumal dlia milykh (1804), and the Damskii zhurnal (1823-1833). In both he wrote in the sentimental spirit. In the 1830's, he published collections of 
Russian fairy tales.

Concerning Bestuzhev-Marlinskii, see p. 258 above.

Gogol had published two volumes of tales in 1831-32 (Vechera na khutore bliz Dikan'ki under the pseudonym Rudy Panko). In 1835 he published four more volumes of tales (Arabeski in two volumes, and Mirgorod, also in two volumes).

1836 В. Ф. Одоевский, „О вражде к просвещению, замечвемой в новейшей литературе"

Сочинения князя В. Ф. Одоевского, III (1844).

. . . В настоящую минуту, не осталось почти ни одного порядочного великого человека и ни одной части его платья, которые не были оклеветаны каким-либо драматиком или романистом.

. . . Наконец взялись за ум; раскрыли Историю Карамзина, вырезали из нее несколько страниц, склеили вместе - и к неописанной радости сделали разом три открытия: 1-е, что такое произведение читатели с небольшим усилием могут принять за роман или за трагедию, 2-е, что с русского переводить гораздо удобнее, нежели с иностранного, и 3-е, что следственно, сочинять совсем не так трудно, как прежде полагали. В самом деле, смотришь - русские имена, а та же французская мелодрама. И многие, многие пустились в драмы и особенно в романы; а критика - этот позор русской литературы - установила для сих произведений особые правнла. За недостатком исторических свидетельств, решили, что настояшие русские нравы сохранились между нынешними извощиками. . . .

Кто употреблял русские имена, того критика называла нащиональным трагиком, кто бессовестнее выписывал из Карамзина, того называла нашиональным романистом, - и гr. А, Б, В, хвастались перед читателями, а читатели радовались, что в романе нет ни одного слова, которое бы не было взято из истории.

До сих пор, все еще шло хорошо; но скоро исторический род наскучил в Европе: там опытные в литературе люди обратились к другой точке зрения; они посмотрели вокруг себя, заметили много смешного, много грустного, вспомнили о романах, которые были в моде у отцов наших - и составился ново-старый род под названием нравственносатирического.

... В то же время демократический дух повеял на Европу; к нему присоединился дух партий - и из всего этого составился новый, действительно чудовищный род литературы, основанный на презрении к просвещению, исполненный ребяческих жалоб на несовершенство ума человеческого, ребяческих воспоминаний о счастливом невежестве предков, возгласов против философии, против машин, и наконец исполненный преступных похвал простоте черни и мужеству ремесленников, разрушаюших прядильные машины. Этот род литературы явился в 
Европе во всех возможных видах; и повестей, и водевилей, и догматических прений. . . .

Легкость сочинения такого рода подняла снизу всю литературную тину: люди едва знающие грамоту и люди знающие ее, но без поэтичес. кого призвания, люди без всякого образования и люди с знаниями достаточными для составления словаря или азбуки, и которые могли бы быть весьма полезными в этой части, - все пустилось в сатирические, историко-нравственные и фантастические произведения разного рода. В этих произведениях не ишите убеждения, откровенности; не ищите новой точки зрения, которая делает рассказ занимательным, если не по происшествию, то по крайней мере по рассказчику; не ишите тех глубоких изъисканий, которые поднимают пред вами завесу с старинных нравов или с тайных движений души современников; не ишите того поэтического волшебства, которое, при недостатке исторических свидетельств, угадывает прошедшее и настоящее; не ищите и простосердечного естественного описания нравов и характеров; не ищите ничего девственного, невольно вылившегося из души . . . В сотняХ томов, вместо силы - напышенность, вместо оригинального - чудовищное, вместо остроты - площадные шутки,- и между тем все чужое, все неестественное, все несуществующее в наших нравах.

V. F. Odoevskij (1803-1869), one of the leading members of the Obshchestva liubomud. ria in Moscow, edited the almanac Mnemozina (1824-1825) together with Kiukhel'beker. He has been called the best representative of philosophical romanticism in Russia. A critic of music and a musician himself, he emphasized the musical element in literature. His main work is the collection of tales Russkie nochi (1844).

Odoevskii's remarks seem to be directed against literature of the type known in Germany as Young Germany (Das junge Deutschland and Vormärz) and in France as the école frénétique. G. Büchner, K. Gutzkow, H. Heine, H. Laube, as well as G. Sand, E. Sue, V. Hugo, Jules Janin may have been on Odoevsky's mind. A part from the growing tendency in literature to depict the life of the lower classes (physiological sketch). Odoevskii condemned the tide of historical dramas, melodramas, and novels, which were often composed without a true knowledge of history.

1836 Н. В. Гоголь, [Рецензня, предназначавшаяся для Современника] Н. В. Гоголь о литературе (Москва, 1952).

В последние года два или три новая французкая школа, выразившаяся у нас во многих переводных отрывках и мелодрамах в театре, проявила заметное свое влияние . . . От этого произошло чрезвычайно много самых странных явлений в наших романах. Иногда русский мужичок отпустит такую театрањную штуку, что и римлянин не сделает. 
Подымется с полатей или с своей печки и выступит таким. . .

Какой-нибудь Василий Углицкий или Степан Иванович Кучка 【брякувши чисто русскую потоворку] , после какой-нибудь русской замашки, отпустивши народную поговорку, закричит вдруг: „смерть и ад!"

В другом месте читатель приготовлен к тому, что эти мужики засучат рукава и потузят друг друга, но вместо того видит, что они кинули один на другого мрачный взгляд - „и” . . . Тут обыкновенно автор поставит несколько точек и прибавит: „и поняли друг друга”. А иногда даже прибавит: „и в этом безмолвии произошла страшная драма", и тому подобное. В этом уже и упрекать нельзя, что лицо немного похоже на испанна, или француза (или кого-нибудь) : этого греха не могли избегнуть и большие наши романы и . . . Обший характер этих маленьких романов, которые в таком изобилия и так скоро вырастают на Руси, есть совершенная детскость. Это будет очень несправедливо, если 6 мы сказали, что в них видна глупость одна, в чем часто упрекают их наши журналисты. Совсем нет: не глупость, но создание самого незрелого дитяти, которого и то занимает, и другое; и того хочется ему, и другого: никакой постоянности! Оттуда у него на одной странице столько несообразностей, сколько у другого в целом томе. Каждая строчка у него или ниже целой октавой, или выше другой. У бесталанного, но опытного человека, набившая руку на писаньи, несообразности становятся явны по прочтении только многих страниц; у бесталанного, но неопытного и молодого, их в одной странице.каберется столько, что читатель по ним может вывести безошибочно мнение обо всем сочинении.

Stepan I. Kuchko-Stepan I. Kuchko (12th cent. A.D.), boyar in Suzdal who owned the land where Moscow was founded.

Gogol seems to refer to French romantic novels of the type written by Hugo which were popular in Russia. His criticism applies equally to Bestuzhev-Marlinskii's ultra-romantic tales which were en vogue in the 1830's.

1840 В. Г. Белинский, „Герой нашего времени"

Отечественные записки. Х, 6; X, 7 (1840).

. . . И искусство нашего века есть воспроизведение разумной действительности. Задача нашего искусства - не представить события в повести, романе или драме, сообразно с предполохвнною заранее иелию, но развить их сообразно с законами разумной необходимости. В таком случае, каково бы ни было содержание поэтического произведения, - его впечатление на душу чнтателя будет благодатно, и, следовательно, нравственная цель достигнется сама собою. 
The above lines express Belinskii's views on literature during his Hegelian period when he attempted to reconcile reality with philosophy. Cf. also p. 256 above. Belinskii polemicizes against Nadezhdin's definition of the contemporary novel.

1842 В. Г. Белинскнй, „Объясненне на объясненце по поводу поэмы Гоголя „Мертвые души'" "

Отечественные записки, 11 (1842).

Сперва автор брошюры характеризует древний эпос тем, что этот эпос „основан был на глубоком и простом созерцания и обнимал собою целый определенный мир во всей неразрывной связи его явлений"; что в нем все на своем месте, всякий предмет переносится в него с его правами, с тайною его жизни и т. П. Все это и не ново, и во всем этом нет никакой определенности . . . Потом автор брошюры говорит, что этот эпос, перенесенный на запад, все мелел, мелел, ,.снизошел до романов, $и$. наконеи. до крайней степени своего унихения, до франиузской повести". (стр. 3). „И вдруг среди этого времени возникает древний эпос с своею глубиною и простым величием - является поэма Гоголя. Тот же глубоко приникающий и всевидящий эпический взор, то же всеобъемлющее эпическое созерцание . . . В поэме Гоголя является нам тот древний, гомеровский эпос; в ней возникает вновь его важный характер, его достоннство и широкообъемлющий размер" (стр. 4).

Теперь дело ясно: эпос есть что-то великое; он вполне выразился в созданиях Гомера (,Илиаде" и „Одиссее”); но со времен Гомера до Гоголя до 1842-го сода по Р. Х. все мелел и искажался; Гоголь же вновь воскресил его во всей его первобытной красоте и свежести. . . .

Древне-зллинский эпос мог существовать только для древних эллинов, как выражение их жизни, их содержания в их форме. Для мира же нового его нечего было и воскрешагь, ибо у мира нового есть своя жизнь, свое содержание и своя форма. следовательно, и свой эпос. И эпос нового мира явился преимущественно в романе, которого главное отличие от древне-эллинского эпоса, кроме христианских и других элементов новейшего мира, составляет еше и проза жизни, вошедшая в его содержание и чуждая древне-эллинскому эпосу. И потому роман отнюдь не есть искажение древнего эпоса, но есть эпос новейшего мира, исторически возникнувший и развившийся из самой жизни и сделавшийся ее зеркалом, как „Илиада” и „Одиссея” были зеркалом древней жизни. Г-н Константин Аксаков умолчал о романе, сказав только, и то в выноске, что, конечно, и роман и повесть имеют-де свое значение и свое место в истории искусства поэзии, но что пределы статьи его не позволяют ему распространиться о них (стр. 3). Во:первых, эта выноска явно противоречит с текстом, где определительно сказано, что 
древний эпос, перенесенншй на запад, все мелел, искажался, снизощел до романов и, наконец, до крайней степени своего унихения, до французской повести; следовательно, какое же свое значение, кроме искажения древнего эпоса, могут иметь роман и повесть в глазах г. Константина Аксакова?

.. . Итак, роман совершенно уничтожен г. Константином Аксаковым; но современный эпос проявился не в одном романе исключительно; в новейшей поззии есть особый род эпоса, который не допускает прозы жизни, который схватывает только поэтические, идеальные моменты жизни и содержание которого составляют глубочайшие миросозерцания и нравственные вопросы современного человечества. Этот род эпоса один удержал за собою имя „поэмы”. Таковы все позмы Байрона, некоторые поэмы Пушкина (в особенности „Цыганы" и „Галуб”), также Лермонтова - „Демон, „Мцыри” и „Боярин Орша”.

Belinskii polemicized against K. S. Aksakov who had reviewed Gogol's novel Pokhozhdeniia Chichikova, ili Mertvye dushi (1842) in a brochure entitled Neskol'ko slov o poeme Gogolio "Pokhozhdeniia Chichikova, ili Mertvye dushi" (Moskva, 1842). Aksakov maintained that Gogol had resurrected the ancient epic and had written another hied. Belinskii disputed this view and put forward his own evaluation of Gogol's achievement. The general reaction of the reading public was described by S. T. Aksakov as follows:

..Публику можно было разделить на три части. Первая, в котороЯ заключалась вся образованная молодежь и все люди способные понять высокое достоинство Гоголя, прнняла его с восторгом. Вторая часть состояла, так сказать, из людей, озадаченных, которые, прнвыкнув тешиться сочннениями Гоголя, не могли вдруг понять глубокого и серьезного значения его позмы; они находили в ней много карикатуры и, основываясь на мелочных промахах, счнтали многое неверным и неправдоподобным. . . Третья часть чнтателей обозлилась на Гоголя: она узнала себя в разных лищах позмы и с остервенением вступилась за оскорбление целоя Росни" (Собрание сочикений С. T. Аксокове [ Москва, 1956 ], III, p. 223).

1843 Z.Z., [ Рецензня на карманные физиологин Поль де Кока и Куайльяка ] Северная пчела, 81 (1843).

И как грошовые журналы с политипажами подражают здесь высшим журналам, так и очерки нравов с великолепными политипажами заменяются здесь ,физиологиями". Под сим названием являются теперь в Париже десятками очерки нравов, с лубочными картинками, и задний двор читателей в восторге от физиологий!

Pol' de kok-Charles-Paul de Kock (1793-1871), popular author of vaudeville plays and novels dealing with the life of the lower middle-classes. Kuail iak-Jean-Joseph Louis Couailhac (1810-1885), author of Physiologie du théatre à Paris et en Province (Paris, 1842).

The reviewer refers in particular to de Kock's Physiology of a Married Man 
(translated in 1843) and Couailhac's above-mentioned Physiology of the Theatre.

The genre of the physiological sketch was based on Labruyere's Les characteres ou les Moeurs de ce siecle (Paris, 1688), a book which was popular throughout the 18 th and early 19th centuries. Mercier continued the genre with his Tableau de Paris (1782). In the 19th century, Victor J. E. de Jouy (1764-1846) wrote his satirical sketches of Parisian life. Beginning in 1825, Balzac published tales which were often entitled Physiologie. . . Jules Janin (1804-1874) defined the themes of the physiological sketch in his Confessions (1830). Important collections of physiological sketches were Paris, ou le livre de cent-et-un (1831-1834); Noveau tableau de Paris au XIX siècle (1834-1835); Les francais paint par eux-mêmes (1840-1842); and Le Diable de Paris (1845).

In Russia, the genre became popular in the early 1840's. The most important collection of physiological sketches was Nekrasov's miscellany Fiziologiia Peterburga (1845). Similar collections, often imitating French publications, were Nashi spisannye s natury russkimi (1841); Panorama Sankt-Peterburga (1834); Moskva i Moskvichi (1844); Peterburgskii sbomik (1846; ed. by Nekrasov).

Turgenev's Zapiski okhotnika. Gertsen's Moskva $i$ Peterburg. Goncharov's Ivan Savich Podzhabrin, and Dostoevskii's Zapiski iz merlvogo doma, as well as his Zimnie zametki o letnikh vpechatleniiakh, were influenced by the genre. Altogether there appeared over seven hundred (!) physiological sketches in Russia between 1839 and 1848.

1846 В. Г. Белинский, „Сочянения Александра Пушкина", (Статьа одиннапиатая и последняя)

Отечественные зеписки, X, 10 (1846).

Повести в прозе Пушкина, хотя и далеко не могут равняться в достоинстве с лушими стихотворными его произведениями даже первого периода его деятельности, однако тем не менее принадлежат к замечательным произведениям русской литературы. . . .

В 1831-м году вышли „Повести Белкина", холодно принятые публикою и еще холоднее журналами. Действительно, хотя и нельзя сказать, чтоб у них уже вовсе не было ничего хорошего, все-таки эти повести были недосгойны ни таланта, ни имени Пушкина. Это что-то вроде повестей Карамзина, с тою только разницею, что повести Карамзина имели для своего времени великое значение, а повести Белкина были ннже своего времени. . . .

„Пиковая дама" - собственно не повесть, а мастерской рассказ. В ней удивительно верно очерчена старая графиня, ее воспитанница, их отношения и сильный, но демонически-эгоистический характер Германа. Собственно, это не повесть, а анекдот: для повести содержание „Пиковой дамы" слишком исключительно и случайно. Но рассказ - повторяем верх мастерства. ...

„Капитанская дочка" - нечто вроде „Онегина” в прозе. Поэт изображает в ней нравы русского общества в царстование Екатерины. Многие картины по верности, истине содержания и мастерству изложения - чудо совершенства. . . . 
See above, p. 259.

1846 В. Г. Белинския,, „Взгляд на лттературу 1846 года” Современник, I, 1 (1847).

За исключением Гоголя, который создал в России новое искусство, новую литературу и которого гениальность давно уже признана не нами одними и даже не одной России только, мы видим в натуральной школе довольно талантов, от весьма замечательньх до весьма обыкновенных. Но не в талантах, не в их числе видим мы собственно прогресс литературы, а в их направления, их манере писать. Таланты были всегда, но прежде они украшали природу, идеализировали действительность, то есть изображали несуществующее, рассказывали о небывалом, а теперь они воспроизводят жизнь и действительность в их истине. ...

Натуральную школу обвиняют в стремлении все изображать с дурной стороны. Как водится, у одних это обвинение - умышленная клевета, у других - искренная жалоба. Во всяком случае, возможность подобного обвинения показывает только то, что, натуральная школа, несмотря на ее огромные успехи, существует еще недавно, что к ней не успели еще привыкнуть и что у нас еще много людей карамзинского образования, которых риторика имеет свойство утешать, а истина огорчать. Разущеется, нельзя чтобы все обвинения против натуральной школы были положительно ложны, а она во всем была непогрешительно права. Но если бы ее преобладающее отрицательное направление и было одностороннею крайностию, - и в этом есть своя польза, свое добро: привычка верно изображать отрицательные явления жизни даст возможность тем же людям или их последователям, когда придет время, верно изображать и положительные явления жизни, не становя их на ходули, не преувеличивая, словом, не идеализируя их риторически.

The Natural School in Russian literature had been propagandized by Belinskii from the middle of the 1840 's. His Introduction to the miscellany Fiziologiia Peterburga (SanktPeterburg, 1845, ed. by $N$. Nekrasov) has been considered the manifesto of the new trend. It appears that the name "natural'naia shkola" was first used by Bulgarin in a feuilleton in Severnaia pchela (no. 22, Jan. 26, 1846). Bulgarin said there that, .г. Некрасов принадлежит к новоһ, т.е. натуральноЯ литературноЯ школе, утверждающей. что должно изображать природу без покрова. Мы, напротив, держимся правила . . . природа тогда тољько хороша, когда ее вымоют и причешут. . . нынешняя так называсмая новая литературная школа (уж подлинно школа!) мучит и терзает вас, застваляя читать скучные и вялые нелепицы для того только, чтобы описать или обрисовать словами какого-нибудь пьянюшку, гнусную 6абу, жалкого писиа. грязную комнату, т.е. так называемую натуру в действии, под именем фнзиологии. позм (!!!???) фантазия и т.п."

Belinskii's article from which the above text is taken was his major theoretical statement on the Natural School. 
Натуральная школа стоит теперь на первом плане русской литературы. С одной стороны, нисколько не преувеличивая дела по каким-нибудь пристрастным увлечениям, мы можем сказать, что публика, то есть большинство читателей, за нее: это факт, а не предположение. Теперь вся литературная деятельность сосредоточилась в журналах, а какие журналы пользуются большею известностию, имеют более обширный круг читателей и большее влияние на мнение публики, как не те, в которых помещаются произведения натуральной школы? Какие романы и повести читаются публикою с особенным интересом, как не те, которые принадлежат натуральной школе, или, лучше сказать, читаются ли публикою романы и повести, не принадлежашие к натуральной школе? Какая критика пользуется ббльшим влиянием на мнение публики, или, лучше сказать, какая критика более сообразна с мнением и вкусом публики, как не та, которая стоит за натуральную школу против риторической? С другой стороны, о ком беспрестанно говорят, спорят, на кого беспрестанно нападают с ожесточением, как не на натуральную школу? Партии, ничего не имеющие между собою общего, в нападках на натуралььную школу действуют согласно, едннодушно, ириписывают ей мнения, которых она чуждается, намерения, которых у ней никогда не было, ложно перетолковывают каждое ее слово, каждый ее шаг, то бранят ее с запальчивостию, забывая иногда приличие, то жалуются на нее чуть не со слезами.

С появлением „Миргорода” и „Арабесок” (в 1835 году) и .Ревизора" (в 1836 году) начннается полная известность Гоголя и его сильное влияние на русскую литературу.

Литература наша была плодом сознательной мысли, явилась как нововведение, началась подражательностию. Но она не остановилась на этом, а постоянно стремилась к самобытности, народности, из риторической стремилась сделаться естественною, матуральною. Это стремление. ознаменованное заметными и постоянными успехами, и составляет смысл и душу истории нашей литературы. И мы не обинуясь скажем, что ни в одном русском писателе это стремление не достигло такого успеха, как в Гоголе.

Влияние Гоголя на русскую литературу было огромно. Не только все молодые таланты бросклись на указанный им путь, но и некоторые писатели, уже приобретшие извесность, пошли по этому же пути, оставши свой прежний. Отсюда появление школы, которую противники ее думали унизить названием натуральной. После „Мертвых Душ” Гоголь ничего не написал. На сцене литературы теперь только его школа. Все упреки и обвинения, которые прежде устремлялись на него, теперь 
обращены на натуральную школу, и если еще деляются выходки против него, то по поводу этой школы. В чем же обвиняют ее? Обвинений не много, и они всегда одни и те же. Сперва нападали на нее за ее будто бы постоянные наладки на чиновников. В ее изображениях быта этого сословия один искренно, другие умышленно видели злонамеренные карикатуры. С некоторого времени эти обвинения замолкли. Теперь обвиняют писателей натуральной школы за то, что они любят изображать людей низкого звания, делают героями своих повестей мужиков, дворников, извозчиков, описывают углы, убежища голодной нищеты и часто всяческой безнравственности. Чтобы устыдить новых писателей, обвинители с торжеством указывают на прекрасные времена русской литературы, ссылаются на имена Карамзина и Дмитриева, избиравших для своих сочннений предметы высокие и благородные, и приводят в пример забытого теперь изящества чувствительную песенку: „Всех цветочков боле розу я любил". . . .

Натуральная школа сдедует совершенно противному правилу: возможно близкое сходство изображаемых ею лиц с их образцами в действительности не составляет в ней всего, но есть первое ее требование, без выполнения которого уже не может быть в сочинении ничего хорошего. Требование тяжелое, выполнимое только для таланта!

Роман и повесть стали во главе всех других родов поззии. В них заключилась вся изящная литература, так что всякое другое произведение кажется при них чем-то исключительным и случайным. Причины этого - в самой сущности романа и повести как рода поэзии. В них лучше, удобнее, нежели в каком-нибудь другом роде поззии, вымысл сливается с действительностью, художественное изобретение смешивается с простым, лишь бы верным, списыванием с натуры. Роман и повесть, даже изображая самую обыкновенную и пошлую прозу житейского быта, могут быть представителями крайних пределов искусства, высшего творчества; с другой стороны, отражая в себе только избранные, высокие мгновения жизни, они могут быть лишены всякой поззии, всякого искусства. . . . Это самый широкий, всеобъемлющий род поэзии; в нем талант чувствует себя безгранично свободным. В нем соединяются все другие роды поззии - и лирика как излияние чувств автора по поводу описываемого им события, и драматизм как более яркий и рельефный способ заставлять высказываться данные характеры. Отступления, рассуждения, дидактика, нетерпимые в других родах поззии, в романе и повести могут иметь законное место. Роман и повесть дают полный простор писателю в отношении преобладающего свойства его таланта, характера, вкуса, направления и т.д. Вот почему в последнее время так много романистов и повествователей. И потому же теперь самые пределы романа и повести раздвинулись:кроме „рассказа", давно уже сушествовавшего в литературе как низший и более легкий вид повести, недавно получили в литературе право гражданства 
так называемые физиология, характеристические очерки разных сторон общественного быта. Наконец, самые мемуары, совершенно чуждые всякого вымысла, ценимые только по мере верной и точной передачи ими действительных событий, самые мемуары, если они мастерски написаны, составляют как бы последнюю грань в области романа, замыкая ее собою.

Сближение искусства с жизнию, вымысла - с действительностию В наш век особенно выразилось в историческом романе. Отсюда был только шаг до истинного воззрения на мемуары, в которых такую роль играют очерки характеров и лиц. Если очерки живы, увлекательны значит они не копии, не списки, всегда бледные, ничего не выражающие, а художественное воспроизведение лиц и событий.

. . . В картинах поэта должна быть мысль, производимая ими, впечатление должно действовать на ум читателя, должно давать то или другое направление его взгляду на известные стороны жизни. Для этого роман и повесть с однородными им произведениями - самый удобный род поззии. На его долю преимущественно досталось изображение картин общественности, поэтический анализ общественной жизни. . . .

Belinskii's discussion of the genre of the novel and novella, written in the year of his death, shows that in many respects he remained true to the romantic convictions of his youth. The mixture of romantic and realistic elements in early realistic literature has been classified by D. Fanger as "romantic realism." Three such "romantic realists" were, according to him, Balzac, Dickens, and the young Dostoevskii (see his study Dostoevskii and Romantic Realism (Harvard University Press, 1965]).

1848 А. Ф. Орлов, [ Доклад от 23-го февраля 1848 года ]

М. Лемке, Николаевские жандармы и литература в 1826-1855 22. (Санкт-Петербург, 1909)

Журналы Современник и Отечественные записки, из которых первый издается проф. Никитенкой, а второй Краевским, счнтаются у нас лучшими, имеют перед другими обширнейший круг чнтателей и сходны между собою в духе и направленин. Последнее происходит между прочим от того, что в Современнике участвуют литераторы Иван Панаев, Некрасов и Белинский, которые до 1847 года участвовали в Отечественных записках.

Общий дух этих двух журналов состоит в том, что они изображают природу и людей как они есть, без всяких прикрас и преувеличений, называя себя поэтому писателями матуральной школы и с презрением отзываются о всех прежних и нынешних литераторах, которые описывали и описывают предметы более идеальные, нежели существующие в природе. 
Гордость писателей натуральной школы и особенно успех журна:лов их, Современника и Отечественных записок, возродило такую ненависть к ним других журналистов, что некоторые из последних доказывают, будто бы Отечественные записки и Современник стараются незаметным образом водворять у нас пагубные идеи запада.

Обстоятельство это обязало меня следить за журналами натуральной школы и хотя, по беспристрастном соображении дела, оказывается, что прочие журналисты преувеличивают свои обвинения, ровно нет никакого вероятия, чтобы издатели Современника и Отечественньх записок питали какое-либо злоумышление, но тем не менее они, действительно, странным направлением своим подают повод к разным сомнительным о себе толкам.

Собранные по сему предмету сведения заключаются в сдедующем:

Издатель Современника проф. Никитенко сам по себе есть человек благонамеренный и разумный в суждениях; равно из перешедших к нему от Отчественных записок Панаев и Некрасов, из которых первый пишет только повести, а второй стихи, не имеют важного влияния на дух журнала, особенный же характер новой нашей журналистике придает Белинский.

Участвуя прежде в московских журналах, потом в Отечественных записках, а ныне в Современнике, Белинский всегда отличался от других критиков грубым тоном и резкостью своих суждений. Он не признает никаких достоинств ни в Ломоносове, ни в Державине, ни в Карамзине, ни во всех прочих литераторах, восхищается произведениями одного Гоголя, которого писатели натуральной школы счщтают своим главою, и одобряют только тех писателей, которые подражают Гоголю. Белинский столь громко и столь настоятельно провозглашал свои мнения, что ныне почти все молодые писатели наши считают за ничто всякую старую знаменитость в нашей литературе. Это же мнение постоянно выражается и в журнале Краевского Отечественные записки. Хотя суждения о писателях зависят собственно от вкуса и публики, но, с другой стороны, дерзкие отзывы о старых знаменитостях оскорбляют чувство тех, которые привыкли уважать Державина, Карамзина и проч. , как славу нашего отечества, а с другой - неуважение к литературным знаменитостям может приводить молодых людей к неуважению всего, к чему народ питает благоговение; так, поручик корпуса горных инженеров Банников в показании своем объяснил, что он, напитавшись из Oтечественных записок неуважением к старым нашим литераторам, перешел от этого к неуважению всего, чтимого другими, и властей, и настоящего порядка дел и даже особы Вашего Императорского Величества.

Далее, превознося одного Гоголя, писатели натуральной школы, вдались также в чрезмерную крайность; они хвалят только те сочинения, в которых описываются пьянищы, развратники, порочные и отвратительные люди, и сами пишут в этом же роде. Такое направление имеет свою 
вредную сторону, ибо если все наши литераторы обратятся к подобным сочннениям и публика не будет читать ничего другого, кроме произведений натуральной школы, то в народе, сверх уничтожения чистого вкуса, могут усилиться дурные привычки и даже дурные мысли.

Наконец, вводя в русский язык без всякой существенной надобности новые иностранные слова, например, принципы, прогресс, доктрина, гуманность и проч., они портят наш язык и с тем вместе пишут темно и двусмысленно: твердят о современных вопросах запада, „о прогрессивном образовании" разумея под прогрессом постепенное знакомство с теми идеями, которые управляют современною жизнью цивилизованных обшеств, о „произведениях нашей литературы, в которых больше или меньше выражаются современные стремления", „о том, что когда умы заняты ближайшими предметами, тогда они отвлекаются от предметов прошедшкх, занимавших прежнее общество, так, например. смешно французам в их настоящем положении, при вопросах, теперь их занимающих, восторгаться победами Наполеона и ставить его идеалом государственного могушества". . . .

Обязываюсь повторить, что Современник и Отечественные записки суть лучшие наши журналы; они следят за всеми успехами наук и словесности; быстро и подробно передают чнтателям все новые открытия и изобретения; печатают часто на своих страницах превосходные сочинения и, по справедливости, уважаются публикою. Позтому надобно пожалеть, что журналы эти впадают в крайности и сами себе дают вид чего-то сомнительного. . . .

Поэтому было бы полезно усилить строгость цензурного устава и надзора самими цензорами, чтоб они не пропускали к напечатанию не только прямо преступных мыслей, но даже коммунистических и политических намеков, сомнительных выражений о стремлениях к вопросам запада; останавливали бы грязные сочинения натуральной школы, которые рано или поздно повредят народной нравственности. вкусу образованных людей и русскому языку; отвергали бы непри:личные отзывы о прежних знаменитых писателях наших и вообще о предметах, к которым благомысляшие люди питают уважение, и чтобы журналы Современник и Отечественные записки. особенно статьи Белинского, были прежде опечатания подвергаемы наястрожайшему просмотру цензоров.

A. F. Orlov (1787-1862), diplomat, after 1844 headed the third section of the Czar's Private Chancellery (i.e., the secret police). 


\section{SELECT BIBLIOGRAPHY}

\section{Primary Sources}

Many books and periodicals published during the first half of the 19th century have been reprinted, some on microfiche or microcards. They are listed in:

INTERNATIONALES VERZEICHNIS DER REPRINTS - WORLD GUIDE TO REPRINTS (ed. Christa Gniss et al.). München: "Verlag Dokumentation," in preparation.

Numerous valuable reprints have been published by FINK VERLAG (Munich, FRG), INTERDOCUMENTATION (Zug, Switzerland), UNIVERSITY MICROFILMS (Xerox Corp., Ann Arbor, Mich., U. S. A.), and ZENTRALANTIQUARIAT (Leipzig, GDR).

Editions of Russian authors are listed in:

K. D. Muratova (ed.), ISTORIIA RUSSKOI LITERATURY XIX VEKA. BIBLIOGRAFICHESKII UKAZATEL'. Moscow-Leningrad: “ANSSR,” 1962.

Selected rexts have been reprinted in the following collections:

Aronson, M. and S. Reiser, LITERATURNYE KRUZHKI I SALONY (ed. B. M. Eikhenbaum), Leningrad: "Priboi," 1929.

ARKHIV BRAT'EV TURGENEVYKH (ed. E. J. Tarasov, V. M. Istrin, N. K. Kul'man), vyp. 1-6. St. Petersburg/Petrograd, 1911-21. (Zentral-antiquariat reprint, 1974).

DEKABRISTY. POEZIIA, DRAMATURGIIA, PROZA, PUBLITSISTIKA, LITERATURNAIA KRITIKA (ed. V. Orlov), Moscow-Leningrad: “Khud. lit.," 1951.

EPIGRAMMA I SATIRA. IZ ISTORII LITERATURNOI BOR'BY XIX v. Vol. I (18001840; ed. V. Orlov). Moscow-Leningrad: “Academia," 1931.

Grigor'ev, A. LITERATURNAIA KRITIKA. Moscow: "Khud. lit.," 1967.

Grigor'ev, A. SOCHINENIIA. I. KRITIKA. (Ed. V. S. Krupich). Villanova, PA: "Villanova University Press," 1970.

ISTORIIA ESTETIKI. PAMIATNIKI MIROVOI ESTETICHESKOI MYSLI. V. 4 (ed. V. V. Vanslov, Z. I. Gershkovich, B. S. Meilakh). Moscow: “Iskusstvo," 1969.

LITERATURNYE SALONY I KRUZHKI (ed. N. L. Brodskii), Moscow-Leningrad: "Academia," 1930. (Olms reprint in prep.)

Nadezhdin, N. 1. LITERATURNAIA KRITIKA. ESTETIKA. Moscow: "Khud. lit." 1972.

POETY-RADISHCHEVTSY (ed. V. Orlov), Leningrad, 1935. 
R ANNIE SLAVIANOFILY (A. S. Khomiakov, I. V. Kireevskii, K. S. i I. S. Aksakovy), ed. N. L. Brodskii. Moscow, 1910.

RUSSKAIA LITERATURA XIX v. KHRESTOMATIIA KRITICHESKIKH MATERIALOV (ed. M. G. Zel'dovich and L. la. Livshits), Moscow: "Vysshaia shkola," 1967. 3rd ed.

RUSSKIE ESTETICHESKIE TRAKTATY PERVOI TRETI XIX v. ANTOLOGIIA. 2 vols. Moscow: "Isskustvo," 1974- 5.

RUSSKIE OCHERKI, v. 1 (ed. B. O. Kostelianets and P. A. Sidorov), Moscow: "Khud. lit." 1956.

RUSSKIE PISATELI O IAZYKE. XVII-XX vv. Leningrad, 1954 (Zentral-antiquariat reprint, no. 622).

RUSSKIE PISATELI O LITERATURE (XVIII-XX w), 2 vols. (ed. S. Balukhatyi), Leningrad: "Sovetskii pisatel'," 1939.

RUSSKIE PISATELI O LITERATURNOM TRUDE (XVIII-XX w), (ed. B. Meilakh), 4 vols. Leningrad: "Sovetskii pisatel'," 1954-56.

RUSSKII FEL'ETON (ed. A. V. Zapadov and E. P. Prokhorov), Moscow: “Izd. politicheskoi literatury," 1958.

SBORNIK MATERIALOV K IZUCHENIIU ISTORII RUSSKOI ZHURNALISTIKI, vYp. 1-3 (ed. B. P. Kos'min), Moscow, 1952-56.

Sipovskii, V. V. ISTORICHESKAIA KHRESTOMATIIA PO ISTORII RUSSKOI SLOVESNOSTI, v. Il (2 parts), St. Petersburg, 1910. (2nd ed.)

KHRESTOMATIIA PO ISTORII RUSSKOI ZHURNALISTIKI XIX v. (ed. A. V. Zapadov), Moscow: "Vysshaia shkola," 1965.

Valuable primary material for the study of the period is contained in the numerous 1'ol. umes of the following Soviet series.

PISATEL' V KRITIKE (pub. by "Khud. lit.") e.g., N. V. Gogol' V RUSSKOI KRITIKE, 1953.

I. A. GONCHAROV V RUSSKOI KRITIKE, 1958.

A. S. GRIBOEDOV V RUSSKOI KRITIKE, 1958.

M. IU. LERMONTOV V RUSSKOI KRITIKE, 1951 and 1955.

A. S. PUSHKIN V RUSSKOI KRITIKE, 1950 and 1953.

PISATEL' V VOSPOMINANIIAKH (pub. by “Khud lit.") e.g., V. G. BELINSKII V VOSPOMINANIIAKH SOVREMENNIKOV, 1962.
A. I. GERTSEN V VOSPOMINANIIAKH SOVREMENNIKOV, 1956.
N. V. GOGOL' V VOSPOMINANIIKAH SOVREMENNIKOV, 1952.
M. IU. LERMONTOV V VOSPOMINANIIKAH SOVREMENNIKOV, 1964.
A. S. PUSHKIN V VOSPOMINANIIAKH SOVREMENNIKOV, 1950. 
LITERATURNYE MEMUARY (pub. by "Khud. lit.")

e.g., P. V. Annenkov, LITERATURNYE VOSPOMINANIIA, 1960.

D. V. Grigorovich, LITERATURNYE VOSPOMINANIIA, 1961.

A. V. Nikitenko, DNEVNIK, 3 vols. 1955-56.

1. 1. Panaev, LITERATURNYE VOSPOMINANIIA, 1950.

A. la. Panaeva, LITERATURNYE VOSPOMINANIIA, 1948.

Memoirs by A. I. Koshelev, F. F. Vigel', I. 1. Dmitriev, and G. R. Derzhavin, are being reprinted in the "Memoir Series" (ed. M. Raeff) of Oriental Research Partners (Cambridge, England).

LITERATURNOE NASLEDSTVO (Moscow, 1931-; Kraus reprint), especially the following volumes:

v. 46 (Goethe in Russia)

v. 16-18 (Pushkin)

v. 19-21 (various romantic poets)

v. 22-24 (Chaadaev)

v. 31-32 (French literary influence in Russia)

v. $39-40$ (Gertsen)

v. $41-42$ (Gertsen)

v. 43-44 (Lermontov)

v. $45-46$ (Lermontov)

v. $47-48$ (Griboedov)

v. 55-57 (Belinskij)

v. 58 (Pushkin, Lermontov, Gogol')

v. $59-60$ (Dccembrist writers)

v. $61-63$ (Gertsen, Ogarev)

v. 64 (Gertsen)

II. Reference Works (biographical and bibliographical information)

BIBLIOGRAFICHESKIE UKAZATELI PEREVODNOI BELLETRISTIKI (œd. K. I. Dikson, A. V. Mez'er, D. A. Braginskii), St. Petersburg, 1897 and 1902. (Variorum reprint, 1971).

ISTORIIA RUSSKOI LITERATURY XIX VEKA. BIBLIOGRAFICHESKII UKAZATEL' (ed. K. D. Muratova), Moscow-Leningrad: “ANSSR,” 1962.

Lisovskii, N. M. BIBLIOGRAFIIA RUSSKOI PERIODICHESKOI PECHATI 1703 1900, Petrograd, 1915. (Zentralantiquariat reprint, no. 430).

Mez'er, A. V. RUSSKAIA SLOVESNOST' S XI PO XIX STOLETIE VKLIUCHITEL'NO. 2 parts, Petersburg, 1899-1902. (Zentralantiquariat reprint, 1972).

RUSSKAIA PERIODICHESKAIA PECHAT' 1702-1894 (ed. A. G. Dement'ev, A. V. Zapadov, M. S. Cherepakhov), Moscow: "Goslitizdat," 1959.

RUSSKIE PISATELI. BIOBIBLIOGR AFICHESKII SLOVAR' (ed. D. S. Likhachev, S. I. Mashinskii, S. M. Petrov, A. I. Reviakin), Moscow: "Prosveshchenie," 1971.

RUSSKII BIOGRAFICHESKII SLOVAR', 25 vols. Moscow-St. Petersburg, 1896-1918. (Kraus reprint) 
Smirnov-Sokol'skii, N. RUSSKIE LITERATURNYE ALMANAKHI I SBORNIKI XVIIIXIX vv. Moscow: "Vsesoiuznaia knizhnaia palata," 1956.

Wytrzens, G. BIBLIOGRAPHISCHE EINFÜHRUNG IN DAS STUDIUM DER SLAVISCHEN LITERATUREN, Frankfurt: "Klostermann," 1972.

III. Histories of Russian Literature and Criticism

ISTORIIA RUSSKOI KRITIKI, V. 1, Moscow-Leningrad, “ANSSSR,” 1958.

ISTORIIA RUSSKOI LITERATURY, vols 1-11, Moscow-Leningrad: “ANSSSR," 19411956. (Esp. vols. IV-VII, 1947-1955.)

ISTORIIA RUSSKOI POEZII, Leningrad, “Nauka," 1973.

ISTORIIA RUSSKOI POVESTI (ed. D. S. Meilakh), Leningrad: “Nauka," 1973.

ISTORIIA RUSSKOGO ROMANA, v. 1, Moscow-Leningrad: “ANSSSR,” 1962.

Kuleshov, V. I. ISTORIIA RUSSKOI KRITIKI XVIII-XIX VEKOV. Moscow: "Prosveshchenie." 1972.

Lavrin, J. A PANORAMA OF RUSSIAN LITERATURE, New York: "Barnes \& Noble," 1973.

*Lettenbauer, W. RUSSISCHE LITERATURGESCHICHTE, Wiesbaden, 1958.

Luther, A. GESCHICHTE DER RUSSISCHEN LITERATUR, Leipzig, 1924.

Mirsky, D. S. A HISTORY OF RUSSIAN LITERATURE, London, 1926-27.

Ovsianenko-Kulikovskii, D. N. ISTORIlA RUSSKOI INTELLIGENTSII (v. 7 of his SOBRANIE SOCHINENII.) St. Petersburg: "Prometei," 1911.

Ovsianikov-Kulikovskii, D. N. ISTORIIA RUSSKOI LITERATURY. v. IV, Moscow, 1908-1910 (2nd ed. 1910-1916; reprint Ann Arbor, 1948)

Pypin. A. M. ISTORIIA RUSSKOI LITERATURY (v. 4). St. Petersburg, 1913. (4th ed.)

Pypin. A. M. KHARAKTERISTIKI LITERATURNYKH MNENII OT 20-KH DO 50-KH GG. St. Petersburg, 1873.

*Slonim, M. THE EPIC OF RUSSIAN LITERATURE FROM ITS ORIGIN THROUGH TOLSTOY. New York, 1950.

Sokolov, A. N. ISTORIIA RUSSKOI LITERATURY XIX V. Moscow: "Izd. MGU." 1960. (2nd ed. 1965 ; 3rd ed. 1970)

Sokolov, A. N. OT ROMANTIZMA K REALIZMU, Moscow: “Izd. MGU,” 1957.

"Stender-Petersen, A. GESCHICHTE DER RUSSISCHEN LITERATUR, v. 2, München:

"C. H. Beck," 1957. 
*Tschižewskij, D. RUSSICHE LITERATURGESCHICHTE DES 19. JAHRHUNDERTS v. 1 (Die Romantik), München: “Eidos,” 1964.

IV. Studies of Russian Romantic Literature

"ARZAMAS" I “ARZAMASSKIE" PROTOKOLY, Leningrad, 1932.

Chizhevskii, D. ON ROMANTICISM IN SLAVIC LITERATURE, The Hague: "Mouton," 1957.

Eikhenbaum, B. SKVOZ' LITERATURU, Leningrad, "Academia," 1924.

Eikhenbaum, B. \& Iu. Tynianov (eds.). RUSSKAIA PROZA. Leningrad: "Academia," 1926.

EPOKHA ROMANTIZMA, Moscow-Leningrad: "Nauka," 1974.

"Gadzhiev, A. A. ROMANTIZM I REALISM, Baku: “Elm," 1972.

Gukovskii. G. A. PUSHKIN I RUSSKIE ROMANTIKI, Moscow: "Khud. lit.," 1965.

IZ ISTORII RUSSKOCO ROMANTIZMA, Kemerovo, 1971.

ISKUSSTVO ROMANTICHESKOI EPOKHI, Moscow, 1969.

*Iusufov, R. F. RUSSKII ROMANTIZM NACHALA XIX VEKA I NATSIONALNYE KUL TURY. Moscow: "Nauka," 1970.

"K ISTORII RUSSKOGO ROMANTIZMA. Moscow: "Nauka," 1973.

Lemke, M. NIKOLAEVSKI ZHANDARMY I LITERATURA 1826-1855. St. Petersburg, 1909. (Newport, 1966).

Lettenbauer, W. "Die russische Romantik" in DIE EUROPÄISCHE ROMANTIK, Frankfurt: "A thenäum," 1974.

Lotman, IU. M. A. S. KAISAROV I LITERATURNOOBSHCHESTVENNAIA BOR'BA EGO VREMENI, Tartu, 1958.

Mann. Iu. RUSSKAIA FILOSOFSKAIA ESTETIKA, Moscow: “Isskustvo," 1969.

Matl, J. EUROPA UND DIE SLAWEN, Wiesbaden: "Hanassowitz," 1964.

McLaughlin. S. "Russia. Romanicheskii-Romanticheskii-Romantizm" in 'ROMANTIC' AND ITS COGNATES. THE EUROPEAN HISTORY OF A WORD (ed. H. Eichner), Toron to: "Toronto University Press," 1972.

Meilakh, B. PUSHKIN I RUSSKII ROMANTIZM, Moscow-Leningrad, 1937.

Mordovchenko, N. I. RUSSKAIA KRITIKA PERVOI CHETVERTI XIX V. MoscowLeningrad: "ANSSSR," 1959. 
Neuhäuser, R. TOWARDS THE ROMANTIC AGE. The Hague: “Nijhoff," 1974.

OT KLASSITSISMA K ROMANTIZMU, Leningrad: “Nauka,” 1970.

PROBLEMY ROMANTIZMA, v. 1 (ed. U. R. Foxt), Moscow: “Iskusstvo," 1967.

PROBLEMY ROMANTIZMA, v. 2 (ed. A. M. Gurevich), Moscow: “Iskusstvo," 1971.

RANNIE ROMANTICHESKIE VEIANIIA, Leningrad: “Nauka," 1972.

ROMANTICHESKII METOD I ROMANTICHESKIE TRADITSII V RUSSKOI I ZARUBEZHNOI LITERATURE (ed. L. G. Iudkevich) Kazan': “Izd. KGU," 1974.

ROMANTIZM V RUSSKOI I SOVETSKOI LITERATURE, vyp. 6 (ed. N. A. Guliaev), Kazan': "Izd. KGU," 1973.

ROMANTIZM V RUSSKOI I ZARUBEZHNOI LITERATURE (ed. N. A. Guliaev), Kazan': “Izd. KGU,” 1974.

ROMANTIZM V KHUDOZHESTVENNOI LITERATURE (ed. N. A. Guliaev), Kazan' "Izd. KGU," 1972.

RUSSKII ROMANTIZM. SBORNIK STATEI (ed. A. I. Beletskii), Leningrad: "Academia," 1927.

Sakulin, P. N. IZ ISTORII RUSSKOGO IDEALIZMA. KNIAZ' V. F. ODOEVSKII, v. I, pts I-II, Moscow, 1913.

Setschkareff, W. SCHELLINGS EINFLUSS IN DER RUSSISCHEN LITERATUR DER 20-ER UND 30-ER J AHRE DES XIX. JAHRHUNDERTS, Leipzig, 1939.

*Terras, V. BELINSKII AND RUSSIAN LITERARY CRITICISM: THE HERITAGE OF ORGANIC AESTHETICS. Madison: "University of Wisconsin Press," 1974.

Tynianov, Iu. N. ARKHAISTY I NOVATORY, Leningrad, "Priboi," 1929.

Tynianov, Iu. N. PUSHKIN I EGO SOVREMENNIKI, Moscow: "Nauka," 1968.

"Vanslov, V. V. ESTETIKA ROMANTIZMA. Moscow: "Iskusstvo," 1966.

Veselovskii, A. N. V. A. ZHUKOVSKII. POEZIIA CHUVSTVA I SERDECHNOGO VOOBRAZHENIIA, Petrograd: "Zhizn' i znanie," 1918.

Veselovskii, A. ZAPADNOE VLUIANIE V NOVOI RUSSKOI LITERATURE. Moscow, 1896. (3rd ed. 1906).

Vvedenskii, B. N. ETIUDY O VLIIANII OSSIANOVSKOI POEZII V RUSSKOI LITERATURE, Nezhin, 1918.

Wytrzens, G. DMITRII VLADIMIROVICH VENEVITINOV ALS DICHTER DER RUSSISCHEN ROMANTIK, Graz-Koln: “Böhlau," 1962.

*Wytrzens, G. PIOTR ANDREEVICH VIAZEMSKII. STUDIEN ZUR RUSSISCHEN 
LITERATUR- UND KULTURGESCHICHTE DES 19. JAHRHUNDERTS, Wien, 1961.

Zamotin, I. I. RANNIE ROMANTICHESKIE VEIANIIA V RUSSKOI LITERATURE. Warsaw, 1900.

Zamotin, 1. I. ROMANTIZM DVADTSATYKH GODOV XIX STOLETIIA V RUSSKOI LITERATURE, 2 vols. St. Petersburg, 1911-1913. (2nd ed.).

Zelinskii, B. RUSSISCHE ROMANTIK. 1. KÜNSTLERDICHTUNG, Köln-Wien: "Böhlau," 1974.

Zhirmunskii, V. M. BAIRON I PUSHKIN. IZ ISTORII ROMANTICHESKOI POEMY, Leningrad: "Academia," 1924.

*Works marked with an asterisk contain recent and extensive bibliographies. 
tive author.

Page numbers in italics indicate quotations from the text of the respec-

Achilles 205

Addison, J. $202 f$.

Aeschylos 102, 192

Aesop 36, $201 f$.

Aksakov, K. S.

NESKOL'KO SLOV O POEME GOGOLIA $264 f$.

PETERBURGSKII SBORNIK, IZD. NEKR ASOVYM $142 f$.

Aksakov, S. T. 142

Alexander I 18

Alfieri, V. 35

Anacreon 103, 206f., 223

Ancillon, J. 128

Androssov, V.P.

REVIZOR, KOMEDIIA V PIATI DEISTVIIAKH; SOCHINENIE N.

GOGOLIA 176, 239f.

Annenkov, P. V. 49

Arakcheev, A. A. 214

Aretino, P. 116

Ariosto, L. 127

Aristarchus 138

Aristoteles 102, 106

Arnaud, F. Th. de Baculand 117f., 246

Bacon, F. 64

Balzac, H. 13, 83, 85, 105, 265, 270

Baratynskii, E. A. 5f., 8, 20, 160, 182

ANTIKRITIKA 6

EDA 220

NALOZHNITSA 6

O ZABLUZHDENIIAKH I ISTINE 6

PIRY 220

PREDISLOVIE K OTDELNOMU IZDANIIU POEMY "EDA" 6

Batiushkov, K. N. 2, 3, 5f., 11 f., 14, 17, 19, 22f., 28, 30f., 38, 90ff., 126, 186, 214.

CHUZHOE - MOE SOKROVISHCHE 4

DVE ALLEGORII $146 f$.

NA RAZVALINAKH ZAMKA V SHVETSII 187 
NECHTO O POETE I POEZII 127, $152 \mathrm{f} ., 178 \mathrm{f}$.

O KHARAKTERE LOMONOSOVA 6

OPYTY V STIKHAKH I PROZE 6

OTRYVOK IZ PISEM OFITSERA O FINLANDII 187

PIS'MO GNEDICHU 178

PROGULKA V AKADEMIIU 6

PUTESHESTVIE V ZAMOK SIREI 6

RECH' O VLIIANII LEGKOI POEZII NA IAZYK $6,19 f$.

UMIRAIUSHCHII TASS 193,214

VECHER U KANTEMIRA 6

VIDENIE NA BEREGAKH... 22

Batteux, Ch. 13f., 62, 104

COURS DE BELLES LETTRES 106

LES BEAUX ARTS... 106

Baumgarten, A. G.

MEDITATIONES PHILOSOPHICAE 125

Beaumarchais, P. 62, 233

Belchikov, N. F. 143

Beletskii, A. 85

Belinskii, V. G. $39,49,53,84 f ., 92,93,106,110,143,177,231,251$, $270 f$.

GEROI NASHEGO VREMENI 263

GORE OT UMA $110,139 f ., 241-244$.

IVAN A. KRYLOV $225 f$.

I.ITERATURNYE MECHTANIIA 10-14, 45f., 89, 99f., 109, $135 f$.

OBSHCHEE ZNACHENIE SLOVA LITERATURA $140 f$.

OB"IASNENIIA NA OB"IASNENIE PO POVODU POEMY GOGOLIA

$264 f$.

O MARLINSKOM 47

O NARODNOSTI 49

O RUSSKOI POVESTI I O POVESTIAKH G. GOGOLIA 47, 136f., 170f., $259 f$.

O STIKHOTVORENIIAKH BARATYNSKOGO 160

O ZHIZNI I SOCHINENIIAKH KOL TSOVA $56 f$.

PARIZHSKIE TAINY $162 f$.

PIS'MO GOGOLIU 143

RAZDELENIE POEZII NA RODY I VIDY 193ff, 222

RECH'O KRITIKE 171

RIMSKIE ELEGII $185 f$., $222 f f$.

RUSSKAIA LITERATURA V $1845 \mathrm{~g}$. $55 f$.

SOCHINENIIA ALEKSANDRA PUSHKINA $15 f ., 17,52,163,181$,

$187,188,224 f ., 266$

STIKHOTVORENIIA LERMONTOVA $138,167 f ., 221$

VZGLIAD NA RUSSKUIU LITERATURU 1846 g. 226, 267 
VZGLIAD NA RUSSKUIU LITERATURU $1847 \mathrm{~g} .58 f ., 163 f ., 268 f f$.

Benediktov, V. G. $227 f$.

Benitskii, A.P.

BEDUIN 178

INDUSKAIA SKAZKA 178

NA DRUGOI DEN' 178

VIZIR 178

Beranger, P. J. 52

Bestuzhev-Marlinskii, A. A. 2, 8f., 13, 23, 32, 38, 82ff., 85, 92, 113, 116, 231, 259f., 263

AMMALAT-BEK 258

IZMENNIK 47, 258

LISTOK IZ DNEVNIKA GVARDEISKOGO OFITSERA 47, 258

MULLA-NUR 258

O ROMANE POLEVOGO "KLIATVA PRI GROBE GOSPODNEM"

8f., 92, 98f., 185, 191f., 256ff.

OTVET NA KRITIKU POLIARNOI ZVEZDY 91f., 216

OTVET NA PIS'MO SHISHKOVA 30

PIS'MO K SESTRE $115 f$.

PIS'MO N. POLEVOMU 44

POEZDKA V REVAL 258

REVEL'SKII TURNIR 258

ROMAN I OL'GA 47, 258

RUSSKIE POVESTI I RASSKAZY 13

VZGLIAD NA RUSSKUIU SLOVESNOST'... $156 f$.

ZAMECHANIIA NA KRITIKU... 31

ZAMOK NEIGAUZEN 258

Blair, H. 62

LECTURES ON RHETORIC 106

Bobrov, S. S.

TAVRIDA 73

Boccaccio, G. $203 f$.

Bogdanovich, I. F. 3, 5, 9, 18

DUSHENKA 9, 15, 224

Boileau-Despreaux, N. 13f., 218

L'ART POETIQUE 106

Boian 3

Bolkhovitinov, E. A. 186

SLOVAR' RUSSKIKH PISATELEI 186

Borg, K. F. 114f.

POETISCHE ERZEUGNISSE DER RUSSEN 115

Born, M. 25

KRATKOE RUKOVODSTVO K ROSSISKOI SLOVESNOSTI 25

Bronner, F. X. $212 f$. 
Brusilov, N. P. 70

Buechner, G. 262

Buerger, A. 34f.

LENORE 34f., 90, 109, 169, 208f., 224

Buffon, G. L. 30,248

Bulgarin, F. B. 8, 14, 49, 83, 88, 177, 267

DMITRII SAMOZVANETS 46, 251, 257 f.

IVAN VYZHIGIN $46,51,54,251 \mathrm{f}$.

MAZEPA 258

PETR IVANOVICH VYZHIGIN 252

POSMERTNYE ZAPISKI... 252

PRIMECHANIIA K STAT'E OLINA 96

Byron, G. N. 17, 34, 78, 83, 89, 91, 94, 98, 103, 114, 132, 134, 209, 215 ,

$225,238,265$

BEPPO 221

BRIDE OF ABYDOS 183

CHILDE HAROLD 182

DON JUAN 221

GIAUR 183

MANFRED 34

PRISONER OF CHILLON 215

Calderon de la Barca, P. 98

Camoes, $L$.

OS LUSIADES 153

Casas, B. 147

Catherine the Great 2-5, 18, 266

Cervantes Saavedra, M. 99, 247

DON QUIXOTE 243

Chaadaev, P. Ia. 85

Champollion, J. Fr. 175

Charles, Mme J. 114

Chateaubriand, F. R. 99

ATALA 246

RENÉ 132f., 246

Chekalevskii, P. P.

RASSUZHDENIE O SVOBODNYKH KHUDOZHESTVAKH 64

Chenier, A. 80, 83, 181

Chenier, M. -J. 80

GAIUS GRACCHUS 80

Chulkov, M. 200, 215

Constant, B. 83

ADOLPHE 249

Cooper, J. F. 83, 257 
BRAVO 251

THE LAST OF THE MOHICANS 251

THE PATHFINDER 251

THE PILOT 251

PIONEERS 251

PRAIRIE 251

THE RED ROVER 251

THE SPY 251

Corneille, P. 80

Cottin, M. $177 f$.

Couailhac, J. -J. L. 265

D'Alambert, J. 218, 248

Dante, A. 127, 182, $203 f$.

Dashkov, D. V. 22, 28

O LEGCHAISHEM SPOSOBE... 23

Davydov, D. V. 73, 78, 160, $168 f$.

OCHERK ZHIZNI D. V. DAVYDOVA 78

Delille, J. 71, 72

LES JARDINS 66

Del'vig, A. A. 5f., 8, 20, $83 f$.

Derzhavin, G. R. 2ff., 8f., 10, 15, 17ff., 23, 27, 38ff., 66, 77, 87, 114, 180,

185f., 238, 271

BOG 92

FELITSA 92

K SCHASTIIU 92

LASTOCHKA 92

MECHTA 120

PIS'MO I. I. DMITRIEVU 27

PREDISLOVIE K TRAGEDII "IROD I MARIAMNA" 178

RASSUZHDENIE O URICHESKOI POEZII ILI OB ODE $168,203 f$.,

230

VEL'MOZHA 92

VODOPAD 18,92

Descartes, R. 64

Dickens, Ch. 84, 270

Diderot, D. 62, 175, 218, 233

Dmitriev, I. I. 3, 5, 9, 11, 18f., 27, 66, 68f., 269

BASNI 11

CHUZHOI TOLK 11

ERMAK 11

SKAZKI 11

VZGLIAD NA MOIU ZHIZN' $66 f$.

Dmitriev, M. A. 103, 234, 238

MELOCHI IZ ZAPASA MOEI PAMIATI 128 
O NRAVSTVENNOI TSELI POEZII $127 f$.

OTVET VIAZEMSKOMU 42

Doroshenko, P. 219

Dostoevskii, F. M. 39, 58f., 93, 270

DNEVNIK PISATELIA 39

POKAZANIIA 143

ZAPISKI IZ MERTVOGO DOMA 266

ZMINIE ZAMETKI... 266

Dubenskii, $\mathbf{D}$.

O VSEKH, UPOTREBLIAEMYKH V RUSSKOM IAZYKE, STIKHOT-

VORNYKH RAZMERAKH $205 f$.

DuMarsais, C. 218

Dumas, A. $106 f$.

Dupaty, Ch.

LETTRES SUR L'ITALIE 247

Eckartshausen, 81

Elisabeth Petrovna $3 f$.

Emin, F. 8, 62

Eropkin, P. D. 147

Ershov, P. P. 14

Euripides 192

Fanger, D.

DOSTOEVSKII AND ROMANTIC REALISM 270

Fauriel, C. 220

Feofan Prokopovich, see Prokopovich, F.

Fichte, J. G. 74, 79

Fielding, H. 246

Filimonov, $V$.

OTRYVOK IZ PEREPISKI VALERIIA S REASOM 66

Florian, J.-P. 34f., $259 \mathrm{f}$.

Fonvizin, D. I. 4f., 9 f., 244

Galich, A. I. 239

OPYT NAUKI IZIASHCHNOGO 167,176

Gedeonov, S.

SMERT' LIAPUNOVA $244 f$.

Gei, N. 86

Gellert, Ch. F. 62, 233

Genlis, St. F. 9, 247, 249, 259 f.

Gessner, S. 64f., $212 f$.

Ginguenè, P. L.

HISTOIRE LITTERAIRE D'ITALIE 179

Glagolev, A. G. 
RETSENZIIA NA "RUSLAN I LUUDMILA" $210 f$.

SNOVIDENIE ILI SUD NA GELIKONE 71

ZHITEL' BUTYRSKOI SLOBODY. ESHCHE KRITIKA 112

Glinka, F. N. 8

BEDNOST' I TRUD 206

Glinka, G. 216

Glinka, N.G. $135 f$.

Glinka, S. N. 81

Gnedich, N. I. 23, 27, 32, 34, 73, 83, 174, 185f., 205., 229

MORITS 73

O VOL'NOM PEREVODE BIURGEROVOI BALLADY "LENORA" $208 f$.

PROSTONARODNYE PESNI NYNESHNIKH GREKOV $219 f$

RASSUZHDENIE O PRICHINAKH ZAMEDLIAIUSHCHIKH RAZ-

VITIE... 29f.

RECH' O POEZII I POETAKH $148 f$.

RYBAKI 44

VECHER U KANTEMIRA $126 f$.

Goethe, J. W. 11, 14, 52, 73, 76, 84, 117, 150, 182

DREI ODEN... 93

FAUST 6,114

GOETZ VON BERLICHINGEN $244 f$.

WERTHERS LEIDEN 76, 78, 132f., $246 f$.

Gogol, N. V. 2, 14, 39, 44, 47f., 49, 51, 54, 82-85, 136f., 146, 170f., 193, $215,226,249,259 f ., 267,271 f$.

ARABESKI 49, 261, 268

MERTVYE DUSHI $54,56,176,252,264 f ., 268$

MIRGOROD 49, 56, 261, 268

NESKOL'KO SLOV O PUSHKINE 45

O DVIZHENII ZHURNAL'NOI LITERATURY... 45

OTRYVKI IZ “AVTORSKOI IZPOVEDI" 245

O SOVREMENNIKE 142

PETERBURGSKAIA STSENA V $1835 / 36$ gg. $109 f$.

PETERBURGSKIE ZAPISKI $1836 \mathrm{~g}$. 240f.

PIS'MO M. P. POGODINU 160f。

RETSENZIIA... 262f.

REVIZOR 56, 161, 239f., 244f.,

SHINEL' 142

SSORA IVANA IVANOVICHA... 48, 241

STRASHNAIA MEST' 48

TARAS BUL'BA 48, 241

UCHEBNAIA KNIGA SLOVESNOSTI... 139, 196-199

V CHEM ZHE, NAKONETS, SUSHCHESTVO RUSSKOI POEZII 
18-21

VECHERA NA KHUTORE BLIZ DIKANKI 255, 261

VYBRANNYE MESTA... $17-21,92,215$

Goldsmith, 0. 247

Goncharov, I. A.

IVAN SAVICH PODZHABRIN 266

Gorkii, M. 85

Gray, Th. 68, 72, 217 f.

Grech, N. I. 3f., 8, 13, 32, 81, 84, 209

OBOZRENIE RUSSKOI LITERATURY V 1814 g. 2

OBOZRENIE RUSSKOI LITERATURY V $1815116 \mathrm{gg} .231$

OPYT KRATKOI ISTORII RUSSKOI LITERATURY $4 f$., $90 f$.

PIS'MA NA KAVKAZ 215

Griboedov, A. S. 2, 5, 21, 23, 32, 34, 38, 82, 108

GORE OT UMA $5,139,233 f$., 238-244

O RAZBORE VOL'NOGO PEREVODA BIURGEROVOI BALLADY

"LENORA" 169

PIS'MO P. A. KATENINU 233

Guarini, G. B. $212 f$.

Gukovskii, G. A.

PUSHKIN I RUSSKIE ROMANTIKI 85f., 175

Gutzkow, K. 262

Hafiz 183

Haller, A. 64, 71

Hanka, V. 216

Harder, H. -B. 74

Hebel, J. P. $212 \mathrm{f}$.

Hegel, G. W. F. 135, 145, 244

Heine, H. 85, 262

Herder, J. G. 72, 98f., 126

IDEEN ZUR PHILOSOPHIE... 46

VOLKSLIEDER 174

Herzen, A. I. 107

DILLETANTIZM V NAUKE $92 f$.

KTO VINOVAT 93

LITERATURA I OBSHCHESTVO 45, 161

ZAPISKI ODNOGO MOLODOGO CHELOVEKA 93

Hesiod 131, 223

Hoffmann, E. T. A. 83f., 176, 191

Homer 32, 102, 137, 156, 179f., 205f., 213, 220f., 264

ILIAD 102, 184, 205, 221, 164

ODYSSEE $155,221,264$

Horace 102, 104, 201f., 206f., 217 f. 
Hugo, V. 83f., 97, 101, 106ff., 159, 262

CROMWELL 83, 106

HERNANI 85

NOTRE DAME DE PARIS 107

Hume, D. 62, $165 f$.

Hutcheson, F. 62 ,

INQUIRY INTO THE IDEA OF BEAUTY 65

TREATISE ON THE PASSIONS 65

lazykov, N. M. 6, 20

Il'in, $\mathbf{N}$. I.

VELIKODUSHIE, ILI REKRUTSKII NABOR 229

Istrin, V. M. 144

Izmailov, V. I. 17, 259 f.

Janin, J. 262

CONFESSIONS 266

Jean Paul (Richter) 84, 223, 243, 247

VORSCHULE DER AESTHETIK 94

Josephus Flavius

ON THE JUDEAN WAR 178

Jouy, V. J. 266

Jugurtha 192

Juvenal 104

Kachenovskii, M. T. 22, 27, 28, 112

Kaisarov, A. S. 216

Kamenev, G. B. 73

Kant, I. 74, 79, 81, 240

Kantemir, A. 2f., 10, 26, 202

Kapnist, V. V. 3, 15, 87

Karamzin, N. M. 2-5, 7, 9-12, 14ff.. 22, 25f., 28, 30, 32, 38, 39, 40, 63, 73

77, 82, 108f., 111f., 117, 141, 176, 214, 224, 232, 234, 246, 248, 257,

$259,261,266$ f., 269, 271

BEDNAIA LIZA 5, 224

CHTO NUZHNO AVTORU 75

FILALET K MELODORU 75

MELODOR K FILALETU $75 f$.

NECHTO O NAUKAKH... $64 f ., 75$

O SLUCHAIAKH I KHARAKTERAKH... 41

OSTROV BORNGOL'M $\mathbf{7 2 , 7 5}$

PANTEON ROSSIISKIKH AVTOROV $I$

PIS'MA RUSSKOGO PUTESHESTVENNIKA 5, 24, 71, 101, 247

PREDISLOVIE K AL MANAKHU "AONIDY" 68f. 
SIERRA MORENA 75

Katenin, P. A. 2, 5, 23, 32, 34f., 38, 82, 84, 108, $109,232 f$.

ACHILLES AND HOMER 174

ANDROMACHE 174

OL'GA 34f., 43, 109, $208 f$.

OTVET NA OTVET $31 f$.

PISMO K IZDATELIU S. $0.30 f$.

RAZMYSHLENIIA I RAZBORY 159

SAPPHO 174

SOPHOCLES 174

UBIITSA 35

Kaverin, V.

BARON BRAMBEUS 259

Khemnitser, 1. 1. 3, 15, 18

Kheraskov, M. M. 3, 5, 8, 14, 16, 40, 62, 175

KADM I GARMONIIA 224, 246

Khmel'nitskii, N. I. 216, 219, 241

Khomiakov, A. S. 6f., 84, 191

DMITRII SAMOZVANETS 237

ERMAK 237

O VOZMOZHNOSTI RUSSKOI KHUDOZHESTVENNOI SHKOLY $59 f$.

Khvostov, D. I. 106

Kireevkii, I. V. 8, 14, 39, 55, 84f., 184, 191, 231

BIBLIOGRAFICHESKIE STATI $53 f$.

OBOZRENIE RUSSKOI SLOVESNOSTI ZA $1829 \mathrm{~g} .7,159$

OBOZRENIE RUSSKOI SLOVESNOSTI ZA $1831 \mathrm{~g}$. 134f.

OBOZRENIE SOVREMENNOGO SOSTOIANIIA LTERATURY $54 f$.

Kireevskii, P. V. 84, 191

Kirsha Danilov

DREVNIE RUSSKIE STIKHOTVORENIIA 186, 211, 221

Kiukhel'beker, V. K. 2, 23, 32, 38, 43, 82, 108f., 113, 209, 220

DNEVNIK $33,221,238$

O NAPRAVLENII NASHEI POEZII... $32 f ., 42 f ., 92,182 f ., 217 f$.

OTRYVOK IZ PUTESHESTVII... 156

PISTO N. G. GLINKE $137 f$.

PROKOFII LIAPUNOV 237

Kliucharov, F. P. 186

Klopstock, F. G.

DER TOD ADAMS 66

DER MESSIAS 193

Kniazhnin, Ia. B. 3, 8

Kock, P. 54, 83

Kogan, P. 86 
Kol'tsov, A. V. $56.58,164,227$

Komarov, $M$.

OBSTOIATEL'NOE I VERNOE OPISANIE... 200

Konashevich-Sagaidachnyi 216, 219

Koshelev, 39

Kostrov, E. I. 3, 31

Kozlov, V. U. 20

Kraevskii, A. A. 93, 270 ff.

Krechetov, N. Kh. 107

Kriukovskii, M.

POZHARSKII 237

Kroneberg, A. I.

MYSLI OB IZIASHCHNYKH ISKUSSTVAKH 131,158

Krylov, I. A. 9, 11, 16, 23, 33, 36, 53f., 82, 130, 165, 201f., 225f., 227

KAIB 178

Kuchko. St. 263

Kukol'nik, N. V. 14, 139, 240

KNIAZ' M. V. SKOPIN-SHUISKII 237

RUKA VSEVYSHNEGO... 237

Kurganov 8

Kuzikov, V. 81, 220

Labruyère, J.

LES CHARACTERES... 266

Lacepède, B. G.

HARMONIES DE LA NATURE 187

Lafontaine, J. 18, $201 \mathrm{f}$.

LaHarpe, J. F. 13f., 22, 62, 248

Lamartine, A. 83, 114

MÉDITATIONS POÉTIQUES $113 f$.

Laube, H. 262

Lavater, J. K. 73, 76, 150

Lazhechnikov, I. I. 83, 85, 176

BASURMAN 258

LEDIANOI DOM 258

POSLEDNII NOVIK 258

Legouvé, G. M.

ETEOCLE ET POLYNICE 80

Leibniz, G. W. 30

Lemke, $M$.

NIKOLAEVSKIE ZHANDARMY... 270ff.

Lermontov, M. Iu. 21, 82, 140, 161, 221, $226 f$.

BOIARIN ORSHA 265

DEMON 221,265 
GEROI NASHEGO VREMENI 176, 263

HADSHI ABREK 221

MTSYRI 265

Lessing, G. E. $201 f$.

Lewis, M. G. 79

THE MONK 79

Lobanov, M. E. 138

MNENIIA... 0 DUKHE SLOVESNOSTI... $116 f$.

Locke, J. 62, 166

Lomonosov, M. V. 2ff., 8, 10, 18f., 24ff., 31f., 38ff., 77, 117, 180, 207f.,

215, 246, 271

NA VZIATIE KHOTINA 10

Longinus 102

Lotman, Iu. $M$.

RUSSO I RUSSKAIA KUL'TURA... 70

Louis XV $212 f$.

L'vov, $\mathbf{N}$.

SOBRANIE NARODNYKH PESEN 200

Macpherson, J. 5,68

SONGS OF OSSIAN $72,174,179$.,

Maikov, A. N. 39

Maikov, V. I. 3, 164

Maikov, V. N. 60

STIKHOTVORENIIA KOL'TSOVA $57 f$.

Makarov, M. N. 259f.

Makarov, P. I. $26 f$.

KRITIKA NA KNIGU POD NAZVANIEM „RASSUZHDENIE...” $26 f$.

Maksimovich, M. A. 84

Mallet

MONUMENTS DE LA MYTHOLOGIE... 174

Marie Antoinette 76

Marivaux, P. C. 62

Martynov, I. I. 87, 94, 146

O KRITIKE 144

Masal'skii, K. P. 14

Mazeppa, I. 216, 219

Meilakh, B. 86

Meleagros of Gadara

ANTHOLOGIA GRAECA 213

Mel'gunov, N. A. 161

Mercier, L.S. 246

MON BONNET DE NUIT 247

SONGES PHILOSOPHIQUES 247 
TABLEAU DE PARIS 247,266

Merzliakov, A. F. $12,73,76,125 f$.

OB IZIASHCHNOM... 150f., 205

O GENII, OB IZUCHENII POETA,... 150

PEREVODY IZ GEORGIK 206

PIS'MO IZ SIBIRI 209

PIS'MO VERTERA K SHARLOTE $77 f$.

RASSUZHDENIE O ROSSIISKOI SLOVESNOSTI... $125 f$.

SLOVO O DUKHE,... 200f.

Meshcherskii, E. P.

O LITERATURE RUSSKOI $184 f$.

Milonov, M. V. 214

K RUBELLIIU 214

PADENIE LIST'EV 214

Milton, J.

PARADISE LOST 193

Minin 253

Mohammed 183, 215

Molière 157, 234

Montesquieu, Ch. L. 81

LETTRES PERSANNES 178

Moore, Th. 103, 183

LALLA ROOKH 180 .

Mordovchen ko, N. I.

RUSSKAIA KRITIKA PERVOI CHETVERTI... 126

Moreau, J. M. 152

Murav'ev, A. N.

TAVRIDA 6

Murav'ev, M. N. 3, 6, 62f., 175

UDOVOL'STVIE I SKORB 65

Murav'ev-Apostol, I. M. $230 \mathrm{f}$.

PISMA IZ MOSKVY V NIZHNII NOVGOROD 146

Musin-Pushkin, M. N. 200

Nadezhdin, N. I. $\quad 6,8,36,39,52,82,84 f ., 99,105,130,237,264$

EVROPEIZM I NARODNOST'... 35f., 49ff., 130

LETOPISI OTECHESTVENNOI LITERATURY 8, 256

O NACHALE, SUSHCHNOSTI I SUD'BAKH... 105

ROSLAVLEV, ILI RUSSKIE V 1812 g. ... 254

SOVREMENNOE NAPRAVLENIE PROSVESHCHENIIA $133 f$.

Narezhnyi, V. T. 73, 83, 229, $248 f$.

ARISTON 249

BURSAK 249

CHERNYI GOD 249 
DMITRII SAMOZVANETS 80

DVA IVANA 249

ROSSIISKII ZHILBLAZ 249

SLAVENSKIE VECHERA 249

ZAPOROZHETS 249

Nechai, D. 219

Nekrasov, N. A. 59, 185, 270 ff.

FIZIOLOGIIA PETERBURGA 177,

MOSKVA, POEMA... $118 f$.

PETERBURGSKII SBORNIK 142, 177, 266

RUSSKIE VTOROSTEPENNYE POETY 226ff

STO RUSSKIKH LITERATOROV ... $36 f$.

Nestor 3

Newton, I. 30

Niemcewicz, J. U. 219

Nikiten ko. A. V. 15, $270 \mathrm{ff}$.

OPYT ISTORII RUSSKOI LITERATURY $141 \mathrm{f}$.

DNEVNIK 106

Nikolev, N. P. 62

Nikon 3

Nodier, Ch. 12

Noel 178

Novalis (Hardenberg, F. L.) 87,169

Novikov, N. I. 4, 7, 14

Odoevskii, V. F. $39,43,48,85,191$

O VRAZHDE K PROSVESHCHENIIU... $261 f$.

Ogarev, N. P.

PIS'MO M. L. OGAREVOI 52

Olin, N. P. 96

OTVET NA PRIMECHANIIA BULGARINA 88

Orlov, A. A. 50f., 54

Ovid 103

DOKLAD $270 f f$.

Ozerov, V. A. 2, 11, 31, 88, 101, 153, 179f., $231 \mathrm{f}$.

DMITRII DONSKOI $180,231 \mathrm{f}$.

EDIP V AFINAKH 180, 231

FINGAL 2, 180, 231

POLIKSENA 180,231

Palei 219

Panaev, I. I. 59, 85, 270 f.

LITERATURNYE VOSPOMINANIIA $106 f ., 139,240$

Parny, E. D. 34f., 83 
POÉSIES EROTIQUES 178

LES SCANDINAVES 178

Pavlov, M. G. 105, 133

Percy, Th.

RELIQUIES OF ANCIENT POETRY 174

Peter I 2f., 10, 51, 58, 216

Petrarca, F. $203 f$.

Petrashevskii, M. V. 58, 140

Petrov, V. P. 3, 31

Phaedrus $201 \mathrm{f}$.

Pigault-Lebrun 249

Pindar 104, 206f., 220, 223

Piron, A. 234

Pisarev, A. A. 73, 241

RASSUZHDENIE O SLOVESNOSTI 146,165

Pixérecourt, R. Ch. 80

Pleshcheev, A. N. 39, 59

Pletnev, P. A. 41

ANAKREONTICHESKAIA ODA... 130

A. S. PUSHKIN 210

DVA ANTOLOGICHESKIE STIKHOTVORENIIA 213

ISTORIIA POEZII... 161

NAL' I DAMAIANTI... $188 f$.

OPYT ISTORII RUSSKOI LITERATURY... $141 \mathrm{f}$

ORLEANSKAIA DEVA SHILLERA $101 f$

PIS'MO K GRAFINE... 95

RYBAKI, IDILLIIA GNEDICHA $128 f$.

SATIRY, POSLANIIA I DRUGIE... 214

Pogodin, M. P. 6, 55, 84, 160f., 191

CHERNAIA NEMOCH' 255

KAK AUKNETSIA... 255

MARFA POSADNITSA $6,236 f$.

NISHCHII 255

PETR I 237

Pogorel'skii, A. 6

Polevoi, K. A.

O NOVOM NAPRAVLENII V RUSSKOI SLOVESNOSTI $185 f$.

Polevoi. N. A. 6, 8, 48f., 84, 96, 102ff., 106, 130

ABADONNA 49, 258

BLAZHENSTVO BEZUMIIA 49

EMMA 47, 48, 258

ISTORIIA RUSSKOGO NARODA 258

KLIATVA PRI GROBE GOSPODNEM 92, 98, 185, 191f., $256 \mathrm{ff}$.

MECHTY I ZHIZN' 49 
O ROMANAKH VIKTORA GI UGO... 97f., 107, $159 f$.

RASSKAZY RUSSKOGO SOLDATA 47f.

SVIATOCHNYE RASSKAZY 47

ZHIVOPISETS 49,258

Polotskii. S. 3, 10

Pope, A. 218

Popov, M. V. 215

ROSSIISKAIA ERATA 200

Pozharskii 253

Prach', 1. 200

Prévost d'Exiles, A. -F. 62, 246

Prokopovich, F. 2f., 26

Pushkin, A. M. 17

Pushkin, A. S. 2f., 5-9, 12, 14f., 17, 19ff., 23, 31f., 39, 41f., 44, 53 ,

$82-85,99,103.106,110,115,157,163,180,182,186,187$ f., 193 , 204ff., 209f., 215, 218f., 224f., 226f., 232, 238, 255, 259

BAKHCHISARAISKII FONTAN 42, 95, 102

BORIS GODUNOV 46, 237, 251, 258

BEZUMNYKH LET... 223

EVGENII ONEGIN $15,84,96,116,176,214,221,225,257,266$

GRAF NULIN 225,241

IA VAS LIUBIL... 223

IURII MILOSLAVSKII... 253

KAPITANSKAIA DOCHKA 20, 253, 266

KAVKAZSKII PLENNIK 91, 215

MNENIE M. E. LOBANOVA... 138

MOI ZAMECHANIIA O RUSSKOM TEATRE 6

MOTSART I SALIERI 150

NA SMERT' KUTUZOVA 17

NENASTNYI DEN' POTUKH 223

O “EVGENII ONEGINE"... $33 f$.

O NARODNOI DRAME... $236 f$.

O NARODNOSTI V LITERATURE $\quad 6,43$

O POEZII KLASSICHESKOI I ROMANTICHESKOI $104 f$.

O PREDISLOVII g. LEMONT'E... 6, 33, 130

O PROZE 248

O TRAGEDII 232f.

PIKOVAIA DAMA 266

PIS'MO BESTUZHEVU 113

PIS'MO K IZDATELIU 45, $235 f$.

PIS'MO O BORISE GODUNOVE $234 f$.

PIS'MA VIAZEMSKOMU $32,113,169,180 f ., 183$

POLTAVA 43, 225

POVESTI BELKINA 266 
PROSTISH' LI... 223

RUSLAN I LIUDMILA 2f., 17, 35, 51, 111, 113, 128, 132, $210 \mathrm{ff}$.

TSYGANE 225, 241, 265

Pushkin, V. L. $22 f$., 28

DVA POSLANIIA 23

PIS'MO I. I. DMITRIEVU 68

Pypin, A. 85

Racine, J. B.

PHEDRE 114, 132

Racine, L. 13

Radcliffe, A. 79, $246 f$.

THE ITALIAN 79

THE MYSTERIES OF UDOLPHO 79

THE ROMANCE OF THE FOREST 79

Regnard, J. F. $8 f$.

Richardson, S. 246

PAMELA, OR VIRTUE REWARDED 62

Rodzianko, S. 73, 125

RAZGOVOR MEZHDU FILOSOFOM I NATUROIU 76

Rousseau, J. B. 104

Rousseau, J. J. 65f., 81, 175, 246

CONFESSIONS $66,73,249$

EMILE 70

NOUVELLE HÉLOISE 250

Rozhalin, N. M. 39

NECHTO O SPORE PO POVODU ONEGINA $96 f$.

Rueckert, F. 189

Ryleev, K. F. 38, 82, 84, 92, 157, 216

IVAN SUSANIN 219

PERVAIA REDAKTSIIA PREDISLOVIIA K "DUMAM" $218 f$.

PETR V OSTROGOZHSKE 219

PIS'MO PUSHKINU 157

PREDISLOVIE K OTDEL'NOMU IZDANIIU “DUM" 219

Saadi 183

Sakulin, P. 85

Saltykov-Shchedrin, M. E. 93

Sannazaro, J. $212 f$.

Sand, G. 83, 262

Sarnitskii, St. 219

Schaad, J. B. 74

Schelling, F. W. J. $39,74,79,81,83,96 f ., 99,131,135 f ., 160 f ., 167,17$, 239 
PHILOSOPHIE DER KUNST 191

Schiller, F. 52, 80, 84, 92, 94, 101f., 114, 175, 214, 238, 243

DIE JUNGFRAU VON ORLEANS 101

KABALE UND LIEBE 229

DIE RAEUBER 73

Schlegel, A. 13, 17, 83f., 98, 101, 105, 136, 170, 175, 251, 255

LECTURES ON DRAMATIC ART AND LITERATURE 131, 191

Schlegel, F. 83, 99, 172, 175, 177, 191, 251, 255

Schopenhauer, A. 191

Scott, W. 83, 106, 114, 176, 238, 244f., 250f., 254, 256

WAVERLEY 89, 257

Scudery, M. 8f.

Senkovskii, O. I. $14,84,175$

PIS'MO PUSHKINU 259

Shakespeare, W. 13, 54, 72, 83, 98f., 116, 156, 234f., 236, 238 244, 256

HENRY IV 234

KING LEAR 73, 236

Shakhovskoi, A. A. 23, 27,241

RETSENZIIA NA "REKRUTSKII NABOR" $87 f$.

Shelley, P. B.

DEFENSE OF POETRY 165

Shevyrev, S. P. 6ff., 51f., 84f., 161, 245

OB ISKUSSTVE I KHUDOZHNIKAKH 6, 161

O VOZMOZHNOSTI VVESTI ITAL'IANSKUIU OKTAVU 8

ZAMECHANIIA NA ZAMECHANIE KN. VIAZEMSKOGO... 6

Shirinskii-Shikhmatov, P. A. 32

Shishkov, A. S. $2,22,26 f ., 32,36,38,79,82,109,111,124,146,151$,

212,214

PEREVOD DVUKH STATEI... 22

PIS'MO 30

PREDISLOVIE K PEREVODAM IZ LAGARPA 22

PRIBAVLENIE K SOCHINENIIU... 22

RASSUZHDENIE 0 KRASNORECHII... 22, 27f.

RASSUZHDENIE O STAROM I NOVOM SLOGE... 22, 24f., 26, 101

Sipovskii, V. 85

Sismondi, J. Ch. L.

DE LA LITTERATURE DU MIDI DE L'EUROPE 127,174

Smith, A. 62f.

Socrates 152

Somov, 0. M. 39, 41, 84, 99, 109

MOI MYSLI O ZAMECHANIIAKH g. M. DMITRIEVA... 234

OBZOR SLOVESNOSTI ZA $1828 \mathrm{~g} .131$

O ROMANTICHESKOI POEZII 127, 129f., 181, $215 f$.

Sophocles 192, $236 f$. 
Soulié, F. 83, $106 f$.

Southey, R. 117

Spiess, Ch. H. 247

Stael, Mme de 99, 111

CORINNE 246

DE L'ALLEMAGNE 129,174

DE LA LITTERATURE... 174

DELPHINE 246

Stankevich, N. V. 107,142

Stendhal (Marie Henri Beyle)

RACINE ET SHAKESPEARE 98

Sterne, L. 5, 25, 27, 70, 246

THE LIFE AND OPINIONS OF TRISTRAM SHANDY 181

SENTIMENTAL JOURNEY 246

Strakhov, $\mathbf{N}$.

MOI PETERBURGSKIE SUMERKI 247

Stroev, M. P. 216

Sue, E. 83, 106f., 262

Sumarokov, A. A. 2f., 8, 10, 14f., 32, 40, 62, 175, 208, 246

Tasso, T. $125,157,179,193$

JERUSALEM LIBERATED $104,153,193$

Teniers, D. 249

Theocritos 186, $212 \mathrm{f}$.

Thomson, J. 64f., 66, 7 If.

Tieck, L. 6,84

HERZENSERGIESSUNGEN EINES KUNSTLIEBENDEN KLOSTER-

BRUDERS 161

Titov, V. A. $39,51,161$

O DOSTOINSTVE POETA $130 f ., 158$

O ROMANE KAK PREDSTAVITELE OBRAZA ZHIZNI... 250 f.

Tiutchev, F. I. 6ff., 84, 228

Tred 'iakovskii, V. K. 3, 8, 10, 106

Tsertelev, N. A.

NOVAIA SHKOLA SLOVESNOSTI 95

OTRYVOK IZ PISMA... 101

Turgenev, Al. I. $28,41,73,94,168$

Turgenev, An. I. 25, 38, 73, 146, 215

K PORTRETU GETE 76

RECH" "O LIUBVI K OTECHESTVU" 41

RECH' “O POEZII I O ZLOUPOTREBLENIIAKH ONOI" 76, 144

RECH" "O RUSSKOI LITERATURE" 40, 77, 200

Turgenev, I. S. 93

SMERT’ LIAPUNOVA... 244 
ZAPISKI OKHOTNIKA 266

Tynianov, lu. $2,38,109,156$

Uvarov, S. S. 38

O GRECHESKOI ANTOLOGII 213

PIS'MO GNEDICHU 205f

Vellanskii, D. M. 74

Vel'tman, A. F. 2

STRANNIK 258

Venevitinov, D. V. 8, 39, 84, 96f., 191

UTRO, POLDEN', VECHER I NOCH' 169 .

Viazemskii, P. A. 5f., 8, 12, 23, 38, 39, 83f., 101, 109, 129, 168, 169, 180, $183,220,231 \mathrm{f}$.

OB AL'MANAKHAKH $1827 \mathrm{~g} .183 \mathrm{f}$.

O DERZHAVINE 6

O KAVKAZSKOM PLENNIKE 6,91

O MOSKOVSKIKH ZHURNALAKH 116

O ZHIZNI I SOCHINENIIAKH V. OZEROVA 6, 127, 153, 179f., $231 f$.

PIS'MO BESTUZHEVU 156

PIS'MO IZ PARIZHA 6

PIS'MA A. I. TURGENEVU 41,94

PIS'MO V PARIZH 248f.

PIS'MO ZHUKOVSKOMU 113

PREDISLOVIE K "BAKHCHISARAISKOMU FONTANU" $42,95 f$.

PREDISLOVIE K SOCHINENIIAM V. A. OZEROVA 88

PREDISLOVIE K SOCHINENIIAM I. I. DMITRIEVA 6

VMESTO PREDISLOVIIA K BAKHCHISARAISKOMU FONTANU

$6,102 f$.

ZHUKOVSKII I PUSHKIN 6

Vigel', F. F.

PIS'MO ZAGOSKINU 161

ZAPISKI 90

Vigny, A. 83, $106 \mathrm{f}$.

Vingil 32, 102, 104, $131 \mathrm{f}$.

Voeikov, A. F. 14, 49, 84, 206

O POEME PUSHKINA... $211 \mathrm{f}$,

RAZBOR "RUSLANA I LIUDMILY" 113

Volkov, I. 86

Volméranges, B. P. 80

Voltaire 4, 10, 178

Voss, J. H. $212 \mathrm{f}$.

Vostokov, A. Kh. 
Wackenroder, W. H. 6, 161, 191

Wellek, R. 86

CONCEPTS OF CRITICISM 86

Xerxes 192

Young, E.

NIGHT SONGS 72

Zagoskin, M. N. $2,5,36,50,83,85,161,176,251$

IURII MILOSLAVSKII 251-254, 257

ROSLAVLEV ... 257

ZHURNAL'NYE STAT'I $70 f$.

Zamotin, I. 85

Zeltner, H. 160

Zenkovsky, V. 141

Zhukovskii, V. A. 2, 5ff., 9, I1f., 14, 16f., 19, 23, 30f., 38, 44, 62,

$76,82,85,90 f ., 92,94 f ., 97,109,111,113,125 f ., 176,180,182$,

$191,208,210,214 f f ., 224,227$

DNEVNIK 169

ENEIDA 206

LIUDMILA 224, 208f.,

KRASNYI KARBUNKUL 206

MESSIADA 206

MARINA ROSHCHA 259

NAL'I DAMAIANTI $188 \mathrm{f}$.

O BASNE... 6, 165, $201 f$.

O NRAVSTVENNOI POL'ZE... 166, 201

O POEZII DREVNIKH I NOVYKH 6,175

O SATIRE... $202 f$.

PISATEL' $V$ OBSHCHESTVE $6,147-150$

PEVETS V STANE RUSSKIKH VOINOV 208

OVSIANOI KISEL' 206

PISTO K GOGOLIU $171 \mathrm{f}$.

PIS'MO I. I. KOZLOVU 135

PIS'MO K IZDATELIAM... $166 f$.

PIS'MO A. I. TURGENEVU 168

PIS'MO VIAZEMSKOMU 168

PREVRASHCHENIIA OVIDIEVYKH 206

SVETLANA 208

Zschokke, H. 81

KUNO VON KYBURG 81,247 


\section{SLAVIST I SCHE BE I TR ÄGE \\ Verzeichnis der bisher erschienenen Bände}

1. Maurer,J.: Das Plusquamperfektum im Polnischen. 1960, 64 S. -2 . Kadach,D.: Die Anfänge der Literaturtheorie bei den Serben. 1960, V, $182 \mathrm{~S}$. - 3. Moskalik,M.: Janka Kupała, der Sänger des weißruthenischen volkstums. 1961, $241 \mathrm{~s}$. - 4. Pleyer,V.: Das russische Altgläubigentum. 1961, 194 S. - 5. Mihailović,M.: Tempus und Aspekt im serbokroatischen Präsens. 1962, VIII, $64 \mathrm{~S}$. - 6. Rösel,H.: Aus Vatroslav Jagićs Briefwechsel. 1962, $75 \mathrm{~S}$. - 7. Schmidt,A.: Valerij Brjusovs Beitrag zur Literaturtheorie. 1963, $159 \mathrm{~S}$. - 8. Minde, R.: Ivo Andrić. 1962, $198 \mathrm{~s}$. - 9. Panzer,B.: Die Funktion des Verbalaspekts im Praesens historicum des Russischen. 1963, $106 \mathrm{~S}$. - 10. Mrosik,J.: Das polnische Bauerntum im Werk Eliza Orzeszkowas. 1963, 211 S. - 11. Felber,R.: Vojislav Ilíc. 1965, 271 S. - 12. Augustaitis,D.: Das litauische Phonationssystem. 1964, 155 S. - 12a. Auras,C.: Sergej Esenin. 1965, 211 S. - 13. Koschmieder-Schmid,K.: Vergleichende griechisch-slavische Aspektstudien. 1967, 196 S. - 14. Klum, E.: Natur, Kunst und Liebe in der Philosophie vladimir Solov'evs. 1965, $333 \mathrm{~s}$. - 15. Albrecht, E.: Das Türkenbild in der ragusanisch-dalmatinischen Literatur des XVI. Jahrhunderts. 1965, 256 S. - 16. Gesemann,W.: Die Romankunst Ivan Vazovs. 1966, $131 \mathrm{~S}$. 17. Perisić,D.: Goethe bei den Serben. 1968, 304 S. - 18. Mares,F.V.: Die Entstehung des slavischen phonologischen Systems und seine Entwicklung bis zum Ende der Periode der slavischen Spracheinheit. 1965, $87 \mathrm{~S}$. - 19. Holzheid,S.: Die Nominalkomposita in der Illasübersetzung von $N$. I. Gnedic. 1969, $92 \mathrm{~S}$. - 20. Chmielewski,H.: Aleksandr Bestužev-Marlinskij. 1966, 134 S. - 21. Schaller,H.W.: Die Wortstellung im Russischen. 1966, 389 S. - 22. Hielscher,K.: A. S. Puškins Versepik. 1966, 169 S. - 23. Küppers,B.: Die Theorie vom Typischen in der Literatur. 1966,354 S. - 24. Hahl-Koch,J.: Marianne Werefkin und der russische Symbolismus. 1967, 126 S. - 25. Gardner,J.: Das Problem des altrussischen demestischen Kirchengesanges und seiner linienlosen Notation. 1967, IX,270 S. - 26. Baldauf,L.: Der Gebrauch der Pronominalform des Adjektivs im Litauischen. 1967, $104 \mathrm{~S}$. - 27. Kluge,R.-D.: Westeuropa und RuBland im Weltbild Aleksandr Bloks. 1967, $393 \mathrm{~S}$. - 28. Kunert,I.: J. U. Niemcewicz: Spiewy historyczne. 1968, II, $132 \mathrm{~s}$. - 29. Steinke, K.: Studien über den Verfall der bulgarischen Deklination. 1968, x, $133 \mathrm{~s} .-30$. Tschöpl,C.: Vjačes lav Ivanov. 1968, $235 \mathrm{~S}$. - 31. Rehder,P.: Beiträge zur Erforschung der serbokroatischen Prosodie. 1968, $247 \mathrm{~S}$. - 32. Kulman,D.: Das Bild des bulgarischen Mittelalters in der neubulgarischen Erzählliteratur. 1968, $276 \mathrm{~S}$. - 33. Burkhart,D.: Untersuchungen zur Stratigraphie und Chronologie der südslavischen Volksepik. 1968, III, 549 S. - 34. Günther, H.: Das Groteske bei N. V. Gogol'. 1968, 289 S. - 35. Kažoknieks, M.: Studien zur Rezeption der Antike bei russischen Dichtern zu Beginn des 19. Jahrhunderts. 1968, $269 \mathrm{~S} .-36$. Schmidt, H.: Hus und Hussitismus in der tschechischen Literatur des 19. und 20. Jahrhunderts. 1969, 296. S. - 37. Schneider,S.: Studien zur Romantechnik Miroslav krlezas. 1969, $285 \mathrm{~s}$. - 38. Stephan,B.: Studien zur russischen Castuska und ihrer Entwicklung. 1969, 358 S. - 39. Girke,W.: Studien zur Sprache N. S. Leskovs. 1969, VIII, 220 S. - 40. Mareś, F. V.: Diachronische Phonologie des Ur- und Frühslavischen. 1969, $126 \mathrm{~S}$. - 41. Wosien,M.-G.: The Russian Folk-Tale. 1969, 237 S. - 42. Schulz, R.K.: The Portrayal of the German in Russian Novels. 1969, V, $213 \mathrm{~S}$. - 43. Baudisch,G.: Das patriarchalische Dorf im Erzählwerk von Janko M. Veselinović. 1969, $225 \mathrm{~S}$. - 44. Stölting,W.: Beiträge zur Geschichte des Artikels im Bulgarischen. 1970, VII, 296 S. - 45. Hucke,G.:Jurij Fedorovit Samarin. 1970, $183 \mathrm{~s}$. - 46. Höcherl, A.: Zur Ubersetzungstechnik des altrussischen "Jüdischen Krieges" des Jiosephus-Elavilus:

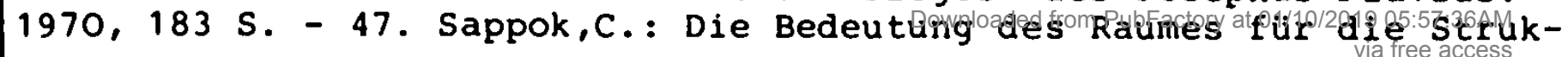


tur des Erzăhlwerks. 1970, $154 \mathrm{~S}$. - 48. Guski,A.: M. Ju. Lermontovs Konzeption des literarischen Helden. 1970, 225 S. - 49. Lettmann, R.: Die abstracta 'um' und 'razum' bei Belinskij. 1971, 167 S. - 50.Lettmann-Sadony,B.: Karolina Karlovna Pavlova. 1971, 181 S. - 51. Brümer, C.: Beiträge zur Entwicklungsgeschichte der frühen Romane L. M. Leonovs, 1971, $231 \mathrm{~S}$. - 52. Schmidt,C.: Bedeutung und Funktion der Gestalten der europäisch östlichen Welt im Werk Thomas Manns. 1971, $366 \mathrm{~S}$. - 53. Eschker,W.: Untersuchungen zur Improvisation und Tradierung der Sevdalinka an Hand der sprachlichen Figuren. 1971, 275 S. - 54. Schmidt, О.: Нензвестный поэт П.Д.Бутурлин. Анализ творчества. 1971, $229 \mathrm{~S}$. 55. Mönke,H.: Das Futurum der polnischen Verba. 1971, 184 S. - 56.Raekke,J.: Untersuchungen zur Entwicklung der Nominalkomposition im Russischen seit 1917. - 57. Müller-Landau,C.: Studien zum Stil der Sava-Vita Teodosijes. 1972, $183 \mathrm{~S}$. - 58. Dippe,G.: August Senoas historische Romane. 1972, $177 \mathrm{~S}$. - 59. Hetzer,A.: Vjaceslav Ivanovs Tragödie "Tantal". 1972, 202 S. - 60. Andreesen,W.: Untersuchungen zur Transiation von Substantiven zu Adjektiven im Altrussischen. 1972, $151 \mathrm{~s}$. - 61. Neureiter, F.: Kaschubische Anthologie. 1973, VIII, 281 S. - 62. Gavrin,M.: Kroatische tbersetzungen und Nachdichtungen deutscher Gedichte zur zeit des Illyrismus. 1973, $226 \mathrm{~S}$. - 63. Grahor,0.: France in the Work and Ideas of Antun Gustav Matos. 1973, 247 S. - 64. Döring,J.R.: Die Lyrik Pasternaks in den Jahren 1928-1934. 1973, XXVI, $390 \mathrm{~S}$. - 65. Högemann-Ledwohn, E.: Studien zur Geschichte der russischen Verserzăhlung in der zweiten Hälfte des 19. Jahrhunderts. 1973, $428 \mathrm{~s}$. - 66. Gonschior,H.: Die geneigten Vokale als Reflexe altpolnischer Längen im wörterbuch von Jan Mączyński. 1973, 391 S. - 67. Talev, I.: Some Problems of the Second South Slavic Influence in Russia. 1973, XIV, $430 \mathrm{~S}$. - 68. Auerbach, I.: Nomina abstracta im Russischen des 16. Jahrhunderts. 1973, VI, $368 \mathrm{~S}$. - 69. Holthusen, J.: RuBland in Vers und Prosa. 1973, $212 \mathrm{~S}$. - 70. GusKi,H.: Die satirischen Komödien V.I.Lukins (1737-1794). 1973, 250 S. 71. Sternkopf,J.: Sergej und Vladimir Solov'ev. 1973, XXXI, 667 S. 72. Wenzel,F.: SPLIT. Ein Verfahren zur maschinellen morphologischen Segmentierung russischer wörter. 1973, IX, $203 \mathrm{~S}$. - 73. Bachmann, E.: Ivo Kozarcanin - Leben und Werk. 1974, 250 S. - 74. Schmidt, B.: Stilelemente der mündichen Literatur in der vorrealistischen Novellistik der Serben und Kroaten. 1974, 309 S. - 75. Jakoby,W.: Untersuchungen zur Phonologie und Prosodie einer kajkavischen Mundart (Gornja Stubica). 1974, X. 256 S. - 76 Schultze,B.: Der Dialog in F.M.Dostoevskijs Idiot. 1974,314 S. - 77. Hilf, E.A.: Homonyme und ihre formale Auflosbarkeit im System Sprache, dargestellt an altrussischen Berufsbezeichnungen. 1974, 129 S. - 78. Wiehl, I.: Untersuchungen zum Wortschatz der Freisinger Denkmäler. Christliche Terminologie. 1974, 169 S. - 79. Pribić,R.: Bonaventura's Nachtwachen and Dostoevsky's Notes from the Underground. A Comparison in Nihilism. 1974, $155 \mathrm{~S}$. - 80. Ziegler,G.: Moskau und Petersburg in der russischen Literatur (ca 1700-1850). Zur Gestaltung eines literarischen stoffes. 1974, VI, $189 \mathrm{~S}$. - 81. Wörn,D.: Aleksandr Bloks Drama Pesnja sud'by (Das Lied des Schicksals), übersetzt, kommentiert und interpretiert. 1974, X, $545 \mathrm{~S}$. - 82. Timberlake,A.: The Nominative Object in Slavic, Baltic and West Finnic. 1974, VI, 265 S. - 83. Baumann,W.:Die Sage von Heinrich dem Löwen bei den Slaven. 1975, 185 S. - 84. EvertsGrigat, S.: V. V. Majakovskij: Pro èto. Ubersetzung und Interpretation. 1975, 262 S. - 85. Mirsky, S.: Der Orient im Werk Velimir Chlebnikovs. 1975, VIII, $112 \mathrm{~S}$. - 86. Ditterich, M.: Untersuchungen zum altrussischen Akzent anhand von Kirchengesangshandschriften. 1975, $147 \mathrm{~S}$. - 87. Cummins,G.M.: The Language of the Old Czech Legenda o svate Katerine. 1975, VIII, 371 S. - 88. Földeak, H.: Neuere Tendenzen der sowjetischen Science Fiction. 1975. VI, $208 \mathrm{~S}$. - 89. Drews, P.: Devetsil und Poetismus. Künstlerische Theorie und Praxis der tschechischen literarischen Avantgarde am Beispiel vitezslav Nezvals, Jaroslav Seiferts und Jifi Wolkers. 1975. 330 S. - 90. Schönle, P. W.: Zur Wortbildung im modernen Russisch. 1975. VIII, 195 S. - 91. Okuka, M.: Sava Mrkalj als Reformator der serbischen Kyrilliza. Mit einem Nachdruck des Salo $123 \mathrm{~S}$. 